UNIVERSIDADE DE BRASÍLIA

INSTITUTO DE LETRAS - IL

DEPARTAMENTO DE LÍNGUAS ESTRANGEIRAS E TRADUÇÃO - LET

PROGRAMA DE PÓS-GRADUAÇÃO EM LINGUÍSTICA APLICẢDA - PPGLA

\title{
CONTRASTES E REFLEXÕES SOBRE O ENSINO DE ESPANHOL EM ESCOLAS PÚBLICAS DO DF: UMA VISÃO REAL ACERCA DA IMPLANTAÇÃO DA LEI 11.161/2005
}

\author{
JULYANA PERES CARVALHO
}

DISSERTAÇÃO DE MESTRADO EM LINGUÍSTICA APLICADA

BRASÍLIA/DF 
UNIVERSIDADE DE BRASÍLIA

INSTIT UTO DE LETRAS - IL

DEPARTAMENTO DE LÍNGUAS ESTRANGEIRAS E TRADUÇÃO - LET

PROGRAMA DE PÓS-GRADUAÇÃO EM LINGUÍSTICA APLICẢDA - PPGLA

\title{
CONTRASTES E REFLEXÕES SOBRE O ENSINO DE ESPANHOL EM ESCOLAS PÚBLICAS DO DF: UMA VISÃO REAL ACERCA DA IMPLANTAÇÃO DA LEI 11.161/2005
}

\author{
JULYANA PERES CARVALHO
}

ORIENTADORA: PROF ${ }^{a}$ DR $^{a}$ MARIA LUISA ORTÍZ ALVAREZ

DISSERTAÇÃO DE MESTRADO EM LINGUÍSTICA APLICADA

BRASÍLIA/DF

2014 
PERES CARVALHO, Julyana. Contrastes e reflexões sobre o ensino de Espanhol em escolas públicas do DF: uma visão real acerca da implantação da lei 11.161/2005. Brasília: Departamento de Línguas Estrangeiras e Tradução, Universidade de Brasília, 2014, 249f. Dissertação de Mestrado.

Documento formal. Autorização de reprodução desta dissertação de mestrado para empréstimo ou comercialização, exclusivamente para fins acadêmicos, foi passada pela autora à Universidade de Brasília e encontra-se arquivado na secretaria do programa. A autora reserva para si os outros direitos autorais de publicação. Nenhuma parte desta dissertação de mestrado pode ser reproduzida sem a autorização por escrito da autora. Citações são estimuladas, desde que citada a fonte. 
UNIVERSIDADE DE BRASÍLIA

INSTITUTO DE LETRAS - IL

DEPARTAMENTO DE LÍNGUAS ESTRANGEIRAS E TRADUÇÃO - LET

PROGRAMA DE PÓS-GRADUAÇÃO EM LINGUÍSTICA APLICADA - PPGLA

\section{CONTRASTES E REFLEXÕES SOBRE O ENSINO DE ESPANHOL EM ESCOLAS PÚBLICAS DO DF: UMA VISÃO REAL ACERCA DA IMPLANTAÇÃO DA LEI 11.161/2005}

\section{JULYANA PERES CARVALHO}

Dissertação de Mestrado submetida ao Programa de Pós-Graduação em Linguística Aplicada da Universidade de Brasília, como requisito parcial à obtenção do título de Mestre em Linguística Aplicada.

APROVADA POR:

Profa. Dra. Maria Luisa Ortíz Alvarez - UnB

Orientadora

Profa. Dra. Isabel Gretel María Eres Fernández - USP

Examinadora Externa

Prof. Dr. Kleber Aparecido da Silva - UnB

Examinador Interno

Prof. Dr. Enrique Huelva Unternbäumen - UnB

Suplente

Brasília, 10 de dezembro de 2014. 
À meus amados pais e irmãos, por serem a minha fonte de inspiração e amor. Aos professores de Espanhol e alunos de escolas públicas que sonham com um ensino de língua espanhola de qualidade, e lutam para tornar este sonho realidade. 


\section{AGRADECIMENTOS}

Ao meu Deus, Senhor da minha vida, por me abençoar e me ensinar que com fé, força e perseverança poderia trilhar essa jornada. A Ele toda hora e glória, bem como minha gratidão por me capacitar, e realizar mais esse desejo do meu coração.

Aos meus amados pais Antônio Carlos e Rosemeri. Me faltam palavras para demonstrar minha gratidão eterna por tanto amor; carinho, estímulo, apoio e dedicação constantes. Por sempre acreditarem na minha capacidade, se orgulharem de mim e, como meus maiores exemplos, me inspirarem a ser uma pessoa melhor.

Da mesma forma, aos meus preciosos irmãos e melhores amigos Karla e Jonas pelo amor; estímulo, presença, compreensão e por sempre acreditarem em mim, mostrando esse amor em palavras e ações. Igualmente, a meu cunhado André pela amizade e estímulo sempre.

Ao meu querido Pedro pelo amor; companheirismo, amizade, cuidado e equilibro. Por me ouvir, me encorajar a prosseguir e permanecer firme, acreditando que eu era capaz.

À minha estimada orientadora, professora Dra. Maria Luisa Ortíz Alvarez, que com carinho acreditou em mim e em minha pesquisa; me acolheu, aconselhou, acalmou, demonstrando sempre confiança em minha capacidade.

Aos professores do PPGLA pela rica contribuição em minha formação acadêmica, especialmente à professora Dra. Maria da Glória Magalhães Reis e ao professor Dr. Kleber Aparecido da Silva pelo apoio, conselhos e contribuições.

A todos meus amigos que de maneira especial, mesmo de perto e de longe, me acompanharam, torceram e me incentivaram nesta jornada.

Às minhas amigas e companheiras de convívio acadêmico Rosilene dos Anjos, Vanessa da Silva e Juliana Ribeiro pelos momentos, conselhos, dúvidas e alegrias compartilhadas.

A todos os participantes desta pesquisa (professores e alunos) que aceitaram contribuir com esta investigação, em unidade de pensamento, que significa cooperar pela melhoria do ensino de Espanhol em escolas públicas do Distrito Federal.

A todos aqueles alunos que passaram por minhas mãos durante a minha experiência docente, servindo de inspiração e estímulo para este estudo.

Aos queridos amigos, antes professores e hoje companheiros de profissão do Centro de Ensino Médio EIT, por contribuírem na minha formação e por me incentivarem nesta caminhada.

À CAPES pelo apoio financeiro, com o qual pude desenvolver esta pesquisa com tranquilidade.

Por fim, a todos os que de alguma forma, contribuíram para que eu fosse a pessoa que hoje sou, assim como para que esta conquista se tornasse realidade. 
“... como quixotinhos lutávamos (e continuamos lutando) contra nossos moinhos de vento". (PARAQUETT, 2009, p. 129) 


\section{RESUMO}

Ao longo dos anos, longo foi o caminho que o ensino de Espanhol percorreu no Brasil. Com um histórico de presença simbólica nos currículos brasileiros comparado às demais línguas (BRASIL, 1942), assim como de exclusões da legislação educacional brasileira (BRASIL, 1961), no início da década de 90 esta realidade foi radicalmente alterada: o Espanhol começou a ascender em solo brasileiro em função de situações econômicas, sociais e políticas vividas pelo Brasil, como o estreitamento dos laços e acordos políticos com países hispa-americanos. Essas situações resultaram na sanção da Lei Federal 11.161 de 05 de agosto de 2005. Como um marco para a democratização do ensino de línguas no Brasil, esta lei instituiu a oferta obrigatória de língua espanhola nos currículos plenos do Ensino Médio e de cunho facultativo no Ensino Fundamental, tornando o Espanhol a única língua estrangeira com legislação própria em solo brasileiro. Prestes a completar 10 anos, a implantação da Lei 11.161/2005 ainda apresenta inúmeros descompassos, sendo vista como uma política linguística mal planejada e executada, pois no cenário da educação básica brasileira ainda há um extenso caminho a ser percorrido entre o discurso e a realidade da prática da lei: descompromisso, omissão e morosidade têm acompanhado o ensino de Espanhol nas escolas, tornando necessárias descrições reais da implantação dessa lei, assim como relatos de como tem se efetivado o ensino de Espanhol nas escolas públicas brasileiras. Dessa forma, este estudo apresenta uma visão real da implantação da Lei 11.161/2005 em escolas públicas do Distrito Federal, por meio da análise contrastiva da realidade de ensino de Espanhol de duas regiões administrativas do Distrito Federal: Taguatinga e Paranoá. Este estudo lança reflexões ao descrever como ocorreu e tem ocorrido a implantação do Espanhol, apresentar as limitações e os descompassos presentes no processo de ensino-aprendizagem desta língua em escolas públicas, comparar as duas realidades, os pontos positivos e negativos e identificar medidas para a melhoria deste ensino. Esta pesquisa é de caráter qualitativo-interpretativista e consiste em uma pesquisa de método misto (YIN, 2010) ao compreender um estudo de casos múltiplos acrescido de uma analise documental. Nesta pesquisa foram utilizados como instrumentos de coleta de dados notas de campo; entrevistas, narrativas, questionários e observação participante. Os resultados desta investigação demonstraram que a realidade de ensino de Espanhol nas duas regiões administrativas analisadas é muito diferente. As oito escolas públicas de ensino médio pesquisadas em Taguatinga apresentaram uma realidade difícil: a reduzida carga horária destinada à disciplina (1 aula semanal de 50 minutos) e suas implicações; a desmotivação e sobrecarga dos professores de língua espanhola, a formação inadequada de alguns professores, a carência de recursos didáticos e tecnológicos e o pouco interesse dos alunos. Já no Paranoá, as duas escolas pesquisadas apresentaram uma realidade animadora, resultado de uma vontade coletiva que gerou melhorias no ensino de Espanhol nessa região: carga horária de quatro aulas semanais de 50min, melhor apoio de recursos técnicos e didáticos, professores com formação adequada, mais motivados e com condições de efetuar um trabalho digno. Quanto aos alunos do Paranoá, estes se apresentaram mais motivados com o ensino de Espanhol. Com base nessas considerações, este estudo abre espaço para a reflexão de como o ensino de Espanhol tem ocorrido, visando contribuir para a melhoria do ensino dessa língua em escolas públicas em todo o país, visto que os dados aqui apresentados poderão levar a uma possível intervenção nos órgãos responsáveis pela implantação da língua espanhola no Brasil.

Palavras-chave: Espanhol. Lei 11.161/2005. Implantação. Política Linguística. 


\section{RESUMEN}

Al largo de los años, largo fue el camino que la enseñanza de Español recorrió en Brasil. Con un historico de presencia simbólica en los planes de estudios brasileños comparado al de los otros idiomas (BRASIL, 1942), así como de exclusiones de la legislación educativa de Brasil (BRASIL, 1961), a principio de los años 90 esta realidad cambió de forma radical: el Español comenzó a ascender en suelo brasileño sobre la base de situaciones económicas, sociales y políticas ocurridas en Brasil, como la profundización de las relaciones y acuerdos políticos con los países hispanohablantes. Esas situaciones dieron lugar a la promulgación de la Ley Federal 11.161 del 05 de agosto de 2005. Como un marco en la democratización de la enseñanza de idiomas en Brasil, esta ley estableció la oferta obligatoria de la lengua española en el currículo de las escuelas de enseñanza media y en las escuelas primarias como opcional, tornando el Español la única lengua extranjera, con legislación propia en suelo brasileño. Después de casi 10 años transcurridos, la aplicación de la Ley 11.161/2005 aún presenta numerosos desajustes, siendo vista como una política lingüística mal planeada y ejecutada, pues en la educación básica brasileña todavía hay un largo camino por recorrer entre la retórica y la realidad de la práctica de implantación de la ley: descompromiso, omisión y retrasos son algunas de las razones que han acompañado el proceso de enseñanza del Español en las escuelas, tornando necesárias descripciones reales de la aplicación de esta ley, en los diferentes contextos así como relatos de la forma en que se ha llevado a cabo ese proceso de enseñanza del Español en las escuelas públicas brasileñas. Por lo tanto, este estudio tiene como objetivo presentar una imagen real de la aplicación de la Ley 11.161 / 2005 en escuelas públicas del Distrito Federal, a través del análisis contrastivo de la implantación del Español en dos de sus regiones administrativas: Taguatinga y Paranoá. Esta investigación trae consigo algunas reflexiones al describir como se desarrolló ese y aún se desarrolla dicho proceso de enseñanza - aprendizaje de esta lengua en escuelas públicas, comparar las dos realidades, los puntos positivos y negativos e identificar medidas para mejorar su enseñanza. Esta investigación es de carácter cualitativo-interpretativo y consiste en un método mixto de investigación (YIN, 2010) al comprender un estudio de caso múltiplos, más un análisis documental. En este estudio fueron utilizados como instrumentos para colectar los datos, notas de campo; entrevistas, narrativas, cuestionarios y observación participante. Los resultados de la investigación demostraron que la realidad de enseñanza del Español en las dos regiones administrativas analizadas es muy diferente. Las ocho escuelas secundarias públicas pesquisadas en Taguatinga presentaron una realidad difícil: reducción de la carga horaria destinada a la materia (1 clase semanal de 50 minutos) y sus implicaciones, la desmotivación y la sobrecarga de los profesores de la lengua, la formación inadecuada de algunos profesores, la falta de recursos pedagógicos y tecnológicos y la falta de interés de los estudiantes.Ya en Paranoá, las dos escuelas pesquisadas presentaron una realidad animadora, resultado de una voluntad colectiva que ha generado mejoras significativas en la enseñanza del Español en esta región: una carga horaria de cuatro clases semanales de 50min, mejor apoyo técnico y educativos, profesores con formacion adecuada, más motivados y con condiciones para hacer un trabajo decente. Cuanto a los estudiantes de Paranoá, se mostraron más motivados con la enseñanza del Español. Sobre la base de estas consideraciones, este estudio abre un espacio de reflexión sobre cómo la enseñanza del Español se ha producido, para que así contribuya para una enseñanza de esta referida lengua en escuelas públicas de todo el país, ya que los datos que aquí se presentan pueden conducir a una posible intervención en los organismos gubernamentales encargados de la aplicación de la lengua española en Brasil.

Palabras clave: Español. Ley 11.161 / 2005. Implantación. Política Lingüística. 


\section{LISTA DE FIGURAS}

Figura 1 - A Lei 11.161/2005 como política pública, política educacional e política linguística 43

Figura 2 - Regiões Administrativas do Distrito Federal...................................................... 109 


\section{LISTA DE QUADROS}

Quadro 1 - Nível secundário - As línguas ensinadas no Ginasial (LO/1942)

Quadro 2 - Nível Secundário - As línguas oferecidas no Curso Clássico e no Curso Científico

(LO/1942) 51

Quadro 3 - As línguas estrangeiras na LDB de 1996 no Ensino Fundamental e Médio

Quadro 4 - Objetivos e Perguntas de Pesquisa 105

Quadro 5 - Perguntas da Entrevista com os docentes e assistentes 131

Quadro 6 - Insatisfação referente à carga horária (Professores de Taguatinga) 143

Quadro 7 - Síntese das respostas da entrevista com docentes e assistentes 164

Quadro 8 - Perguntas do Questionário - alunos 185 


\section{LISTA DE TABELAS}

Tabela 1- As disciplinas referentes a línguas ensinadas no Colégio Dom Pedro II (I) 46

Tabela 2 - As disciplinas referentes a línguas ensinadas no Colégio Dom Pedro II (II) 47

Tabela 3 - As cargas horárias das línguas estudadas (LO/1942)

Tabela 4 - Renda Domiciliar Média Mensal e Per Capita Média Mensal - Taguatinga x

Paranoá (2013)

Tabela 5 - Professores de Espanhol de Taguatinga - DF (2014)

Tabela 6 - Professores de Espanhol do Paranoá - DF (2014)

Tabela 7 - Datas das observações (Taguatinga e Paranoá)

Tabela 8 - Nível de conhecimento dos alunos 188

Tabela 9 - Razões para a motivação dos alunos 191

Tabela 10 - Língua estrangeira escolhida no vestibular/PAS/ENEM 195 


\section{LISTA DE SIGLAS E ABREVIATURAS}

APEs

BTDT

CAPES

CEE's

CIL

CILT

CNE

CODEPLAN

DELE

DF

ENEM

GDF

IC

JK

LA

LAC

LDB

LE

LEM

$\mathrm{LM}$

LO

MEC

MERCOSUL

OCENS

PAS

PCNEM

PCNs

PD

PDAD

PL

PNBE
Associações Estaduais de professores de Espanhol

Biblioteca Digital Brasileira de Teses e Dissertações

Coordenação de Aperfeiçoamento de Pessoal de Nível Superior

Conselhos Estaduais de Educação

Centro Interescolar de Línguas

Centro Interescolar de Línguas de Taguatinga

Conselho Nacional de Educação

Companhia de Planejamento do Distrito Federal

Diplomas de Espanhol como Língua Estrangeira

Distrito Federal

Exame Nacional do Ensino Médio

Governo do Distrito Federal

Instituto Cervantes

Juscelino Kubitscheck

Linguística Aplicada

Linguística Aplicada Crítica

Lei de Diretrizes e Bases da Educação Nacional

Língua Estrangeira

Língua Estrangeira Moderna

Língua Materna

Lei Orgânica

Ministério da Educação

Mercado Comum do Sul

Orientações Curriculares para o Ensino Médio

Programa de Avaliação Seriada

Parâmetros Curriculares Nacionais para o Ensino Médio

Parâmetros Curriculares Nacionais

Parte Diversificada

Pesquisa Distrital por Amostra de Domicílios

Projeto de Lei

Programa Nacional Biblioteca da Escola 
PNLD

RA

$\mathrm{UnB}$
Programa Nacional do Livro Didático

Região Administrativa

Universidade de Brasília 


\section{SUMÁRIO}

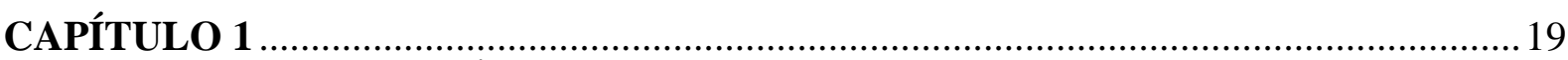

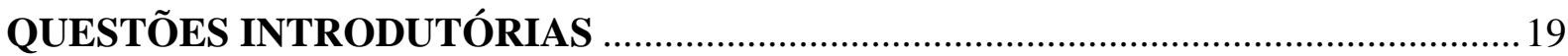

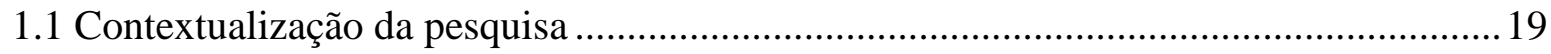

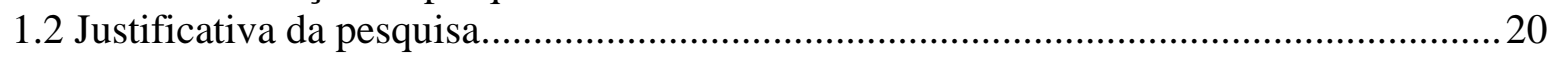

1.2.1 Relevância social: O direito de aprender LE com qualidade ................................21

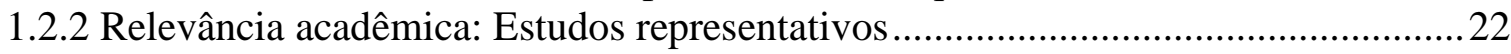

1.2.3 Relevância pessoal e motivação da pesquisadora ................................................. 24

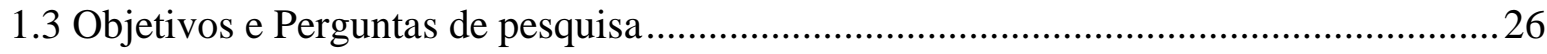

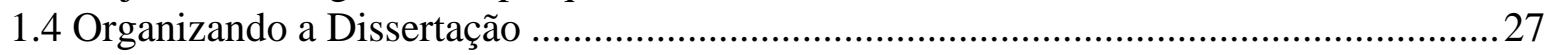

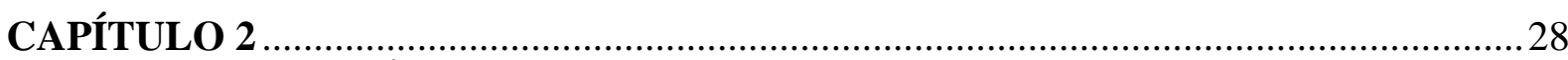

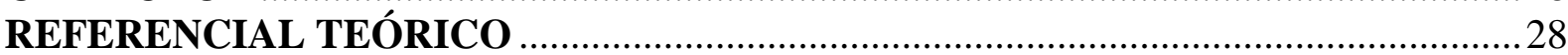

2.1 ATRIBUINDO À PESQUISA UMA DIMENSÃO CRÍTICA …................................ 28

2.1.2 (Re) definindo o objeto de investigação da Linguística Aplicada ............................ 30

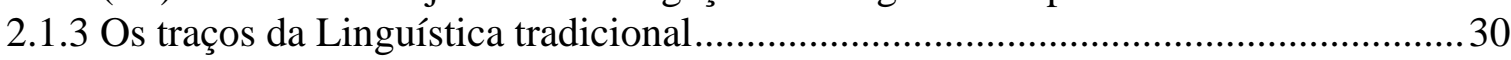

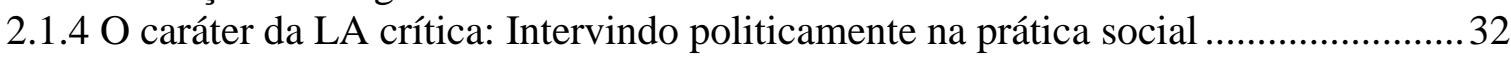

2.1.5 Entre a pesquisa e o sonho: LA, um lugar de "ensaio da esperança" ......................... 34

2.2 POLÍTICA, POLÍTICA PÚBLICA, POLÍTICA EDUCACIONAL E POLÍTICA

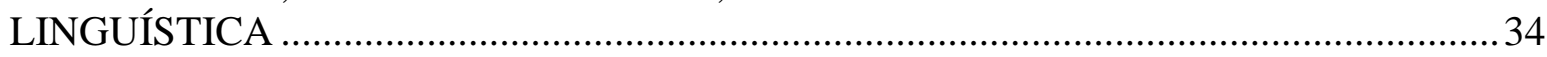

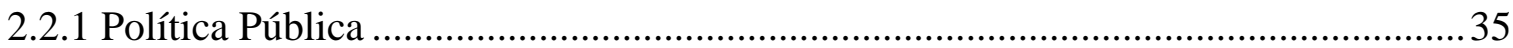

2.2.2 Política Pública Educacional ................................................................................. 38

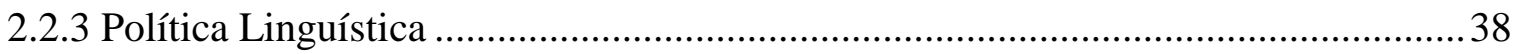

2.2.3.1 Em que medida o homem pode intervir na língua ou nas línguas? ......................4 40

2.2.3.2 Maneiras de o linguista aplicado fazer Política linguística................................... 41

2.3 A PRESENÇA DO ESPANHOL NO SISTEMA EDUCACIONAL BRASILEIRO:

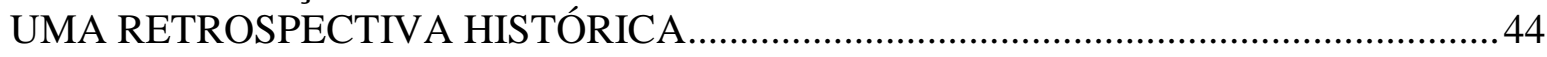

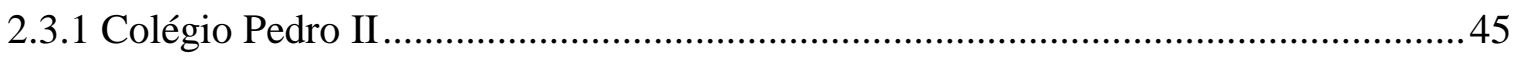

2.3.2 A Lei Rocha Vaz.......................................................................................... 49

2.3.3 A Reforma Francisco Campos ................................................................................. 49

2.3.4 A Reforma de Capanema e a Lei Orgânica do ensino secundário de 1942................50

2.3.5 O PL no 4.606/1958 de Juscelino Kubitscheck: Equiparando o Espanhol ao Inglês 53

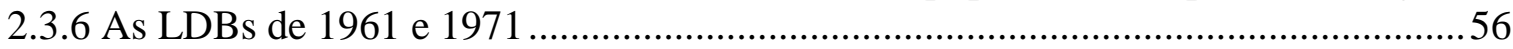

2.3.6.1 A LDB de 1961 e o desaparecimento das LEs da legislação educacional

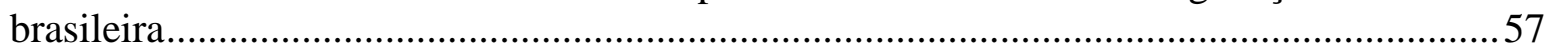

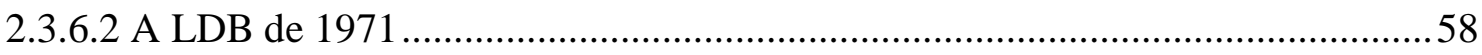

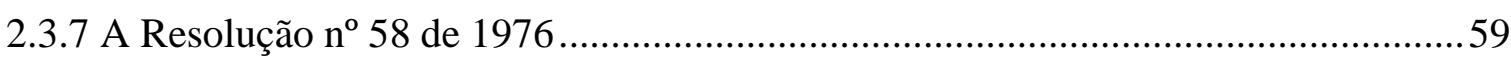

2.3.8 A década de 80 e as primeiras iniciativas para a volta do Espanhol ...........................60

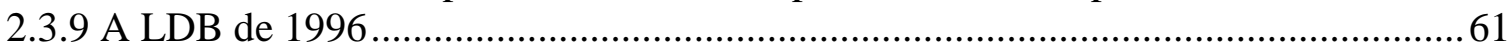

2.4 "A LEI, ORA A LEI”: DESDOBRAMENTOS DA LEI 11.161/2005 ............................65

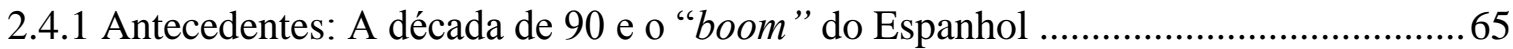

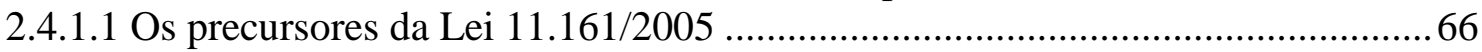

2.4.1.2 O MERCOSUL (1991) e os demais fatores econômicos e políticos.....................67

2.4.2 A sanção da Lei 11.161/2005 e suas implicações .....................................................71

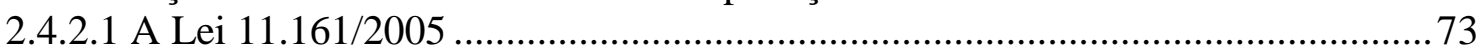

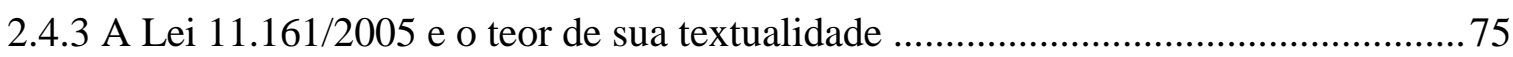

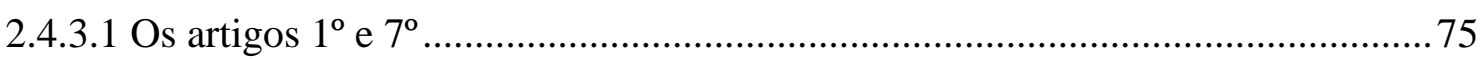

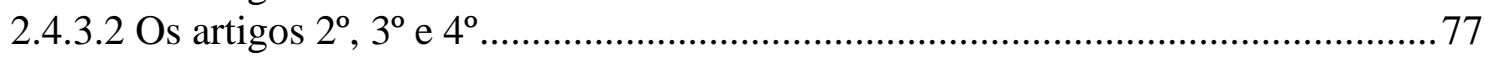


2.4.3.3 Os artigos $5^{\circ}$ e $6^{\circ}$

2.4.3.4 O Conselho Estadual de Educação de Sergipe e o Parecer no 18/2007 ................8 80

2.4.4 As ações governamentais federais positivas ao ensino de Espanhol no Brasil..........81

2.4.5 "Del dicho al hecho hay un trecho": As realidades do ensino de Espanhol ...............82

CAPÍTULO 3

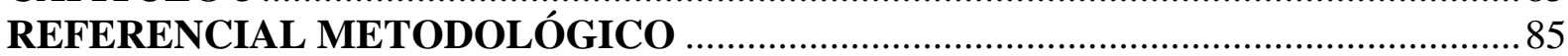

3.1 A pesquisa qualitativa nas Ciências Sociais ............................................................... 85

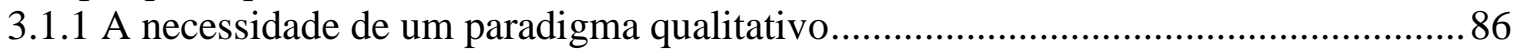

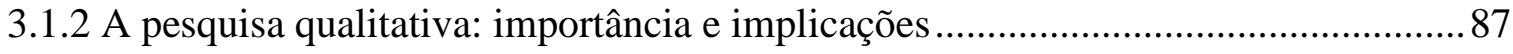

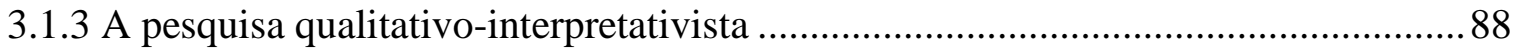

3.1.4 A pesquisa qualitativa e as políticas sociais ............................................................... 89

$3.2 \mathrm{O}$ estudo de caso acrescido da análise documental: uma pesquisa de método misto .....89

3.2.1 Estudo de caso: visibilidade dos problemas da prática educacional..........................90

3.2.2 O estudo de casos múltiplos (YIN, 2010), ou coletivo (STAKE, 1995) …………....92

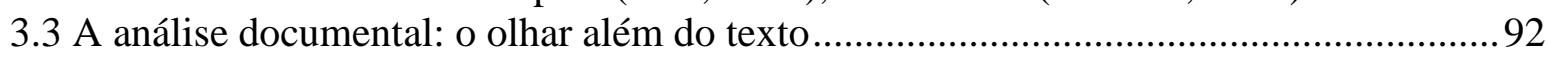

3.3.1 O auxílio do olhar interpretativo da Hermenêutica ...................................................95

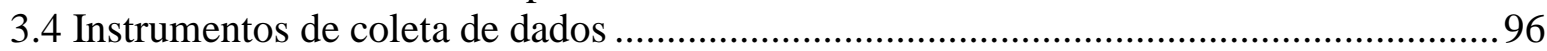

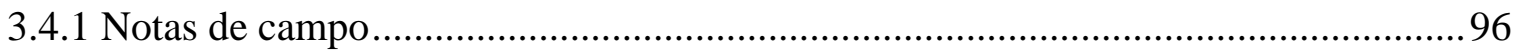

3.4.2 Entrevistas e análise de narrativas ....................................................................97

3.4.3 Questionário com perguntas abertas e fechadas .....................................................99

3.4.4 Observação participante......................................................................................99

3.5 Triangulação: exposição a realidades múltiplas ........................................................100

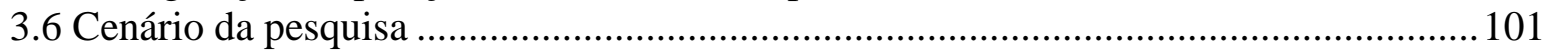

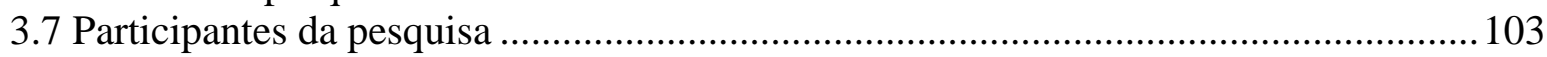

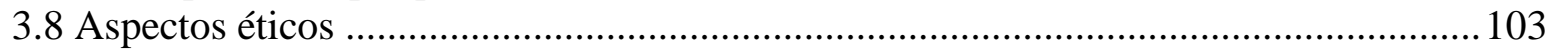

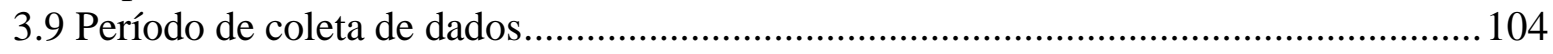

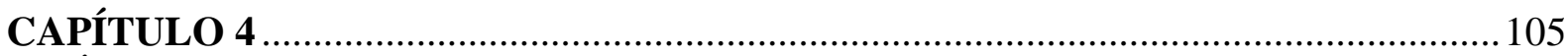

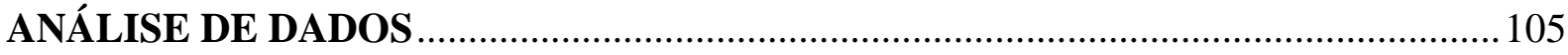

4.1 O ENSINO DE ESPANHOL NO DISTRITO FEDERAL ............................................106

4.1.1 Panorama Socioeconômico e Educacional das RAs Taguatinga e Paranoá .............107

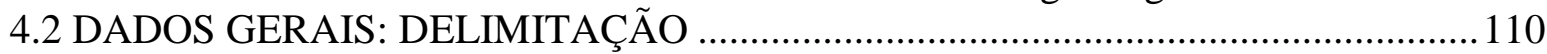

4.2.1 O questionário: Conhecendo as escolas ....................................................................111

4.3 A implantação do Espanhol em Taguatinga - DF e a realidade atual .............................111

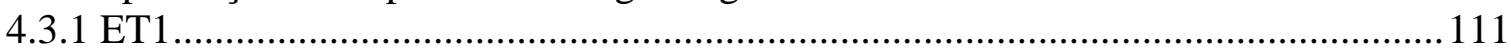

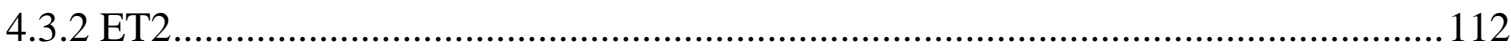

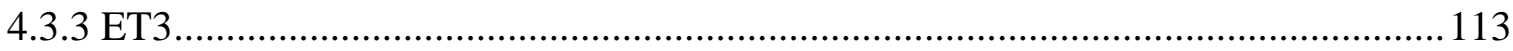

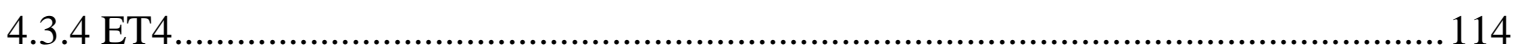

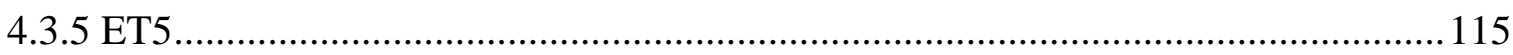

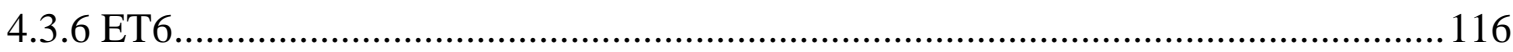

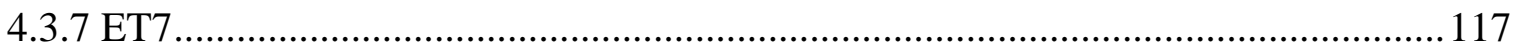

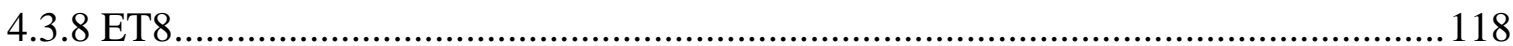

4.3.9 O Panorama geral do ensino de Espanhol em Taguatinga - DF .............................119

4.3.9.1 A carga horária e os professores de Espanhol de Taguatinga - DF ...................123

4.4 A implantação do Espanhol no Paranoá - DF e a realidade atual................................... 126

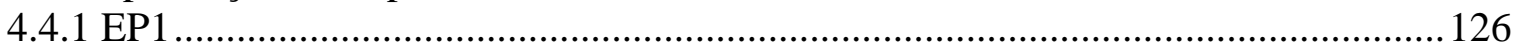

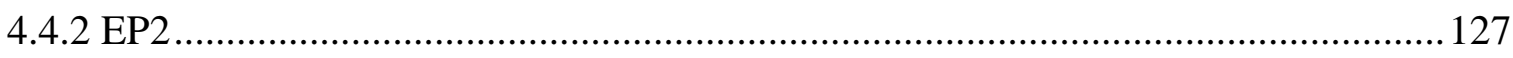

4.4.3 O Panorama geral do ensino de Espanhol no Paranoá - DF ..................................... 128 


\subsection{A ENTREVISTA: CONHECENDO A VISÃO DOS PROFESSORES DE ESPANHOL}

4.5.1 Em sua visão, por qual/quais motivo(s) o Espanhol foi acrescentado ao currículo das escolas públicas?

4.5.2 Como professor, quais as suas satisfações em relação ao ensino de Espanhol em escolas públicas do Distrito Federal

4.5.3 Quais as suas insatisfações (dificuldades) em relação ao ensino de Espanhol em escolas públicas do Distrito Federal? De que maneira essas dificuldades prejudicam o ensino-aprendizagem?

4.5.4 Em sua opinião, como seria a realidade ideal de ensino de Espanhol em escolas públicas do Distrito Federal?

4.5.5. Que medidas práticas poderiam ser tomadas para a melhoria do ensino de Espanhol em escolas públicas do Distrito Federal.

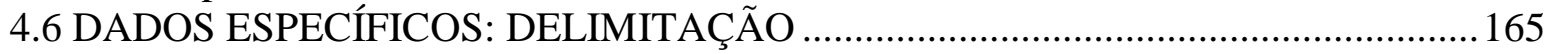

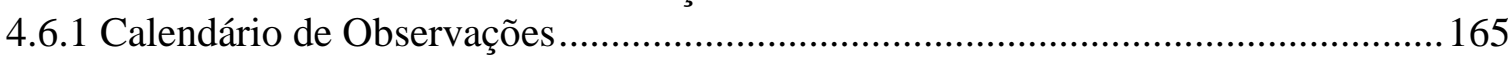

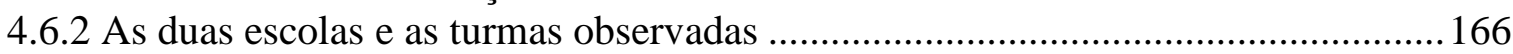

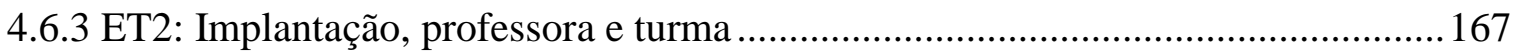

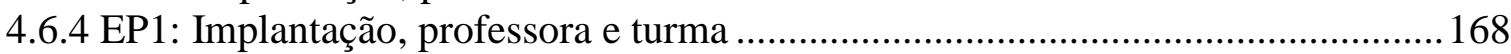

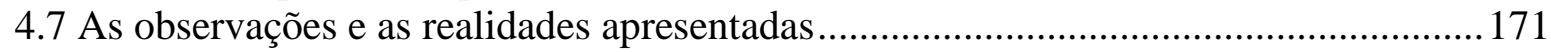

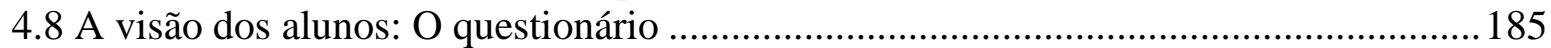

4.8.1 É importante estudar Espanhol na escola? Por quê?................................................ 186

4.8.2 Você já estudou (ou estuda) Espanhol fora da escola? Se sim, onde e durante quanto tempo?

4.8.3 Em sua visão, qual é o seu conhecimento de Espanhol desde o primeiro ano do ensino médio até agora? a) Nenhum, b) Pouco, c) Razoável, d) Mediano, e) Acima da media, f) Excelente

4.8.4 Em sua opinião, é possível aprender Espanhol na escola? Por quê? ....................... 188

4.8.5 Você gosta de ter aulas de Espanhol na escola? Acredita que suas aulas são

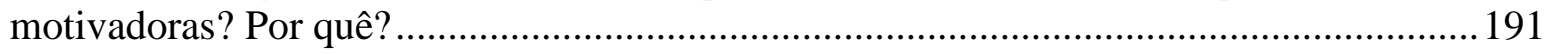

4.8.6 O que te deixa motivado nas aulas de Espanhol? ................................................... 191

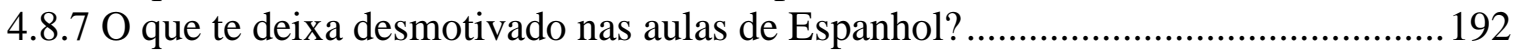

4.8.8 Como você gostaria que fossem suas aulas de Espanhol?..................................... 193

4.8.9 Você acredita que o tempo para as aulas de Espanhol na sua escola é suficiente para

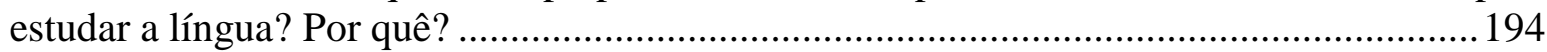

4.8.9.1 Qual será sua língua de opção no vestibular/PAS/ENEM? Por quais motivos

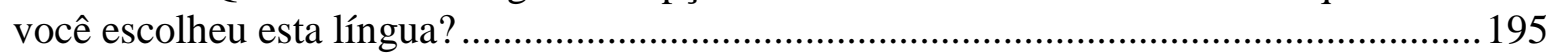

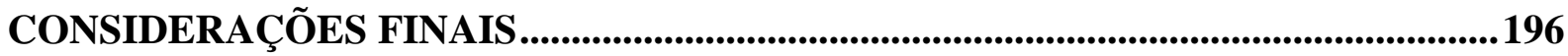

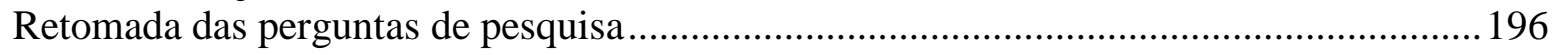

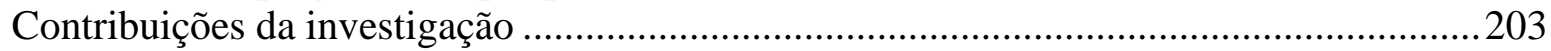

Limitações do estudo e sugestões para pesquisas futuras ..................................................204

REFERÊNCIAS

APÊNDICE A - TERMO DE CONSENTIMENTO (DIRETOR/A) ...................................220

APÊNDICE B - TERMO DE CONSENTIMENTO (PROFESSORAS) .............................. 221

APENNDICE C - TERMO DE CONSENTIMENTO (ALUNOS) .......................................222

APÊNDICE D - TERMO DE CONSENTIMENTO (ALUNOS MENORES DE IDADE) ..223

APÊNDICE E - QUESTIONÁRIO ESCOLAS ................................................................224

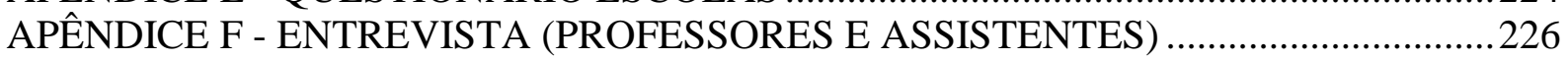




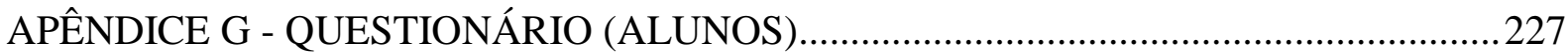

APÊNDICE H - AMOSTRA DE EXCERTO DE FALAS …..........................................228

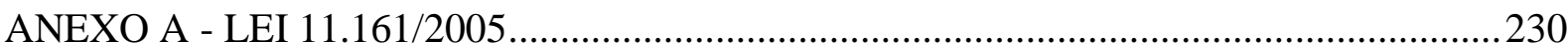

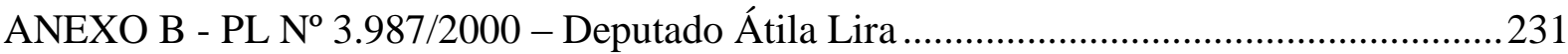

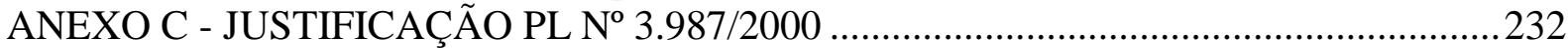

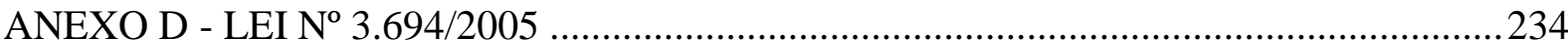

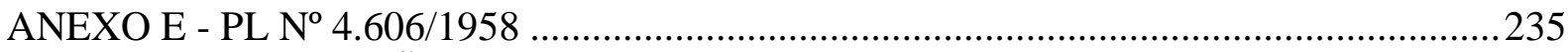

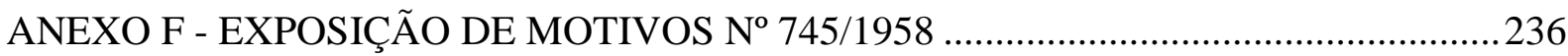

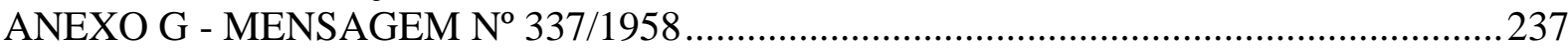

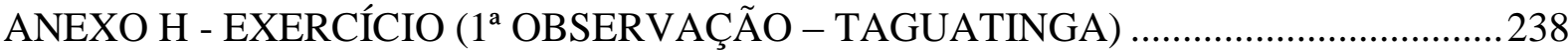

ANEXO I - COMPREENSÃO ORAL (4 ${ }^{\text {a }}$ OBSERVAÇÃO - TAGUATINGA) ................239

ANEXO J - EXERCÍCIO PROFISSÕES (5 $5^{\text {a }}$ OBSERVAÇÃO - TAGUATINGA) ..............240

ANEXO K - EXERCÍCIO AVALIATIVO (4 ${ }^{\mathrm{a}}$ OBSERVAÇÃO - PARANOÁ) ..................241

ANEXO L - EXERCÍCIO IMPERATIVO (5 OBSERVAÇÃO - PARANOÁ) .....................242

ANEXO M - EXERCÍCIO IMPERATIVO II (6 $6^{a}$ OBSERVAÇÃO - PARANOÁ) ..............244

ANEXO N - PROVA DE ESPANHOL, VESTIBULAR UNB 2006 (7º OBSERVAÇÃO -

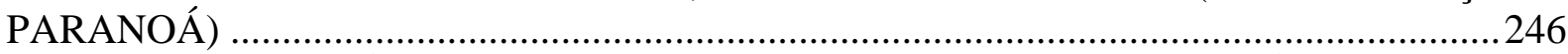

ANEXO O - EXERCÍCIO DE REVISÃO (9a OBSERVAÇÃO - PARANOÁ) ......................248 


\section{CAPÍTULO 1 \\ QUESTÕES INTRODUTÓRIAS}

"Educador, ao contrário, não é profissão; é vocação. E toda vocação nasce de um grande amor, de uma grande esperança." (RUBEM ALVES, 1980 p. 12)

\subsection{Contextualização da pesquisa}

"Não há possibilidade de se ter língua que não esteja afetada desde sempre pelo político. Uma língua é um corpo simbólico-político que faz parte das relações entre sujeitos na sua vida social e histórica" (ORLANDI, 2007, p. 8, grifo meu).

Como bem afirmou Orlandi (2007), desde sempre as línguas foram afetadas pelo político, uma vez que a escolha pelo ensino de uma língua sempre esteve relacionada a fatores de ordem econômica e social. Dessa maneira, as línguas foram se configurando em reflexos das relações de força e poder dos Estados que as utilizam (LE BRETON, 2005), bem como em elementos de comunicação e reflexo social, podendo exercer poder, dissensão e discriminação (VIÑAL JÚNIOR, 2012a).

Assim sendo, o ensino de Espanhol ${ }^{2}$ em solo brasileiro não se deu de maneira distinta, muitos foram os percursos atravessados, bem como as lutas travadas para que hoje, com a sanção e implantação da Lei 11.161/2005, a língua espanhola fosse a única língua estrangeira (doravante LE) a ter legislação própria no Brasil.

Como um marco para a democratização do ensino de línguas no país, "um fator que fez com que todo o cenário de ensino de LEs no Brasil mudasse” (MACIEL, 2012, p. 4), a Lei federal $n^{\circ} 11.161$ de 05 de agosto de 2005, sancionada pelo então Presidente Luis Inácio Lula da Silva juntamente com o Ministro da Educação, Fernando Haddad, regulamentou a oferta obrigatória de Espanhol nos currículos plenos do Ensino Médio, e de cunho facultativo no Ensino Fundamental.

Tal legislação é considerada o resultado final da crescente ascensão da língua espanhola em território nacional, intensificada através dos últimos anos em função de

\footnotetext{
${ }^{1}$ No decorrer da dissertação, introduzirei cada capítulo com um trecho da obra "Conversas com quem gosta de ensinar", de Rubem Alves (1980). Nesta obra o autor discorre sobre a prática docente de forma leve, reflexiva e poética. Rubem Alves, considerado um dos maiores pedagogos brasileiros de todos os tempos foi educador; teólogo, escritor e psicanalista. Seus escritos abordaram diversas áreas tais como teologia; psicologia, filosofia, entre outros.

${ }^{2}$ Ao longo da dissertação, todas as línguas aqui citadas serão apresentadas em letra maiúscula a fim de valorizálas em meu discurso e situá-las em igual patamar.
} 
acordos políticos e estreitamento dos laços com países que têm o Espanhol como língua materna (doravante LM), pois, segundo Haddad (2005), o intuito do governo ao promulgar essa lei era, em primeiro lugar, fortalecer os laços ibero-americanos e sua imagem no cenário internacional (apud PEDROSO el at, 2008, p. 53). Portanto, percebe-se que os objetivos da implantação dessa lei traziam, também, implicações econômicas e políticas. Logo, estamos "diante de um gesto político claro e, sobretudo, de um gesto de política linguística ${ }^{3}$..." (MEC/SEB, 2006, p.128, grifo meu).

No entanto, a política linguística pode ser tanto bem acertada como danosa, podendo ser considerada "malfeita, impulsiva ou feita no calor dos acontecimentos, sobretudo quando vista retroativamente num momento futuro" (RAJAGOPALAN, 2013, p. 37). À luz desta afirmação, a incorporação do Espanhol como disciplina obrigatória tem sido vista como uma política linguística mal planejada e executada, dado que no cenário da educação básica brasileira ainda há um extenso caminho a ser percorrido entre o discurso e a realidade da prática da lei: descompromisso, omissão e morosidade têm acompanhado o ensino de Espanhol nas escolas, tornando necessárias descrições reais do processo de implantação dessa lei, assim como relatos efetivos de como tem se efetivado o ensino de Espanhol nas escolas brasileiras.

Com base nas considerações feitas, este estudo visa trazer reflexões sobre como se deu esse processo de ensino de língua espanhola em escolas públicas do Distrito Federal (doravante DF) por meio de uma análise contrastiva da realidade de ensino de duas Regiões Administrativas ${ }^{4}$ (doravante RAs) do DF, a fim de apresentar uma visão real da implantação da Lei 11.161/2005.

\subsection{Justificativa da pesquisa}

Este estudo justifica-se por sua importância no âmbito social e acadêmico, bem como por sua relevância pessoal. Portanto, nesta seção discorrerei sobre cada um desses aspectos

\footnotetext{
${ }^{3}$ O conceito de Política Linguística será trabalhado no Capítulo 2 da dissertação. Contudo, a fim de proporcionar ao leitor compreensão inicial do tema em questão, compartilho da definição de política linguística trazida por Rajagopalan (2013, p. 21) ao dizer que "a política linguística é a arte de conduzir as reflexões em torno de línguas específicas, com o intuito de conduzir ações concretas de interesse público relativo à(s) língua(s) que importam para o povo de uma nação, de um estado ou ainda, instâncias transnacionais menores".

${ }^{4}$ De acordo com a Constituição Federal de 1988, art. 32, o DF é proibido de subdividir-se em municípios. Durante um tempo, os centros urbanos do DF foram chamados de "cidades-satélites". Entretanto, esta nomenclatura foi proibida pelo decreto $\mathrm{n}^{\circ} 19.040$ de 18 de fevereiro de 1998 e substituída pelo termo "Região administrativa" (RA). Atualmente, de acordo com a Lei $\mathrm{n}^{\circ} 4.745$ de 29 de janeiro de 2012, o DF possui 31 regiões administrativas.
} 
no intuito de expor os fatores que motivaram esta investigação.

\subsubsection{Relevância social: $O$ direito de aprender LE com qualidade}

Segundo a Lei de Diretrizes e Bases da Educação Nacional (1996) e a Declaração Universal dos Direitos Linguísticos (1996), a aprendizagem de uma LE juntamente com a LM é um direito de todo o cidadão. No mesmo pensamento, de grande relevância para a história do ensino de línguas no Brasil, a Carta de Pelotas (2000) ${ }^{5}$ apresenta importantes considerações sobre o ensino de línguas estrangeiras (doravante LEs), dentre as quais, destaco:

- Todo cidadão brasileiro tem direito de ser preparado para o mundo multicultural e plurilíngue por meio da aprendizagem de línguas estrangeiras;

- Há um anseio da sociedade contemporânea em adquirir o conhecimento linguístico necessário para interagir com o mundo intra e além fronteiras;

- O aluno tem direito a um ensino de línguas de qualidade;

- O ensino regular não tem sido capaz de garantir o direito à aprendizagem de línguas, direito esse que acaba sendo usufruído apenas pela camada mais afluente da população.

Tais aspectos são verdadeiros e reais, uma vez que além de possuir o direito de aprender LEs (e aprender com qualidade), nota-se o anseio e a necessidade do brasileiro de aprender outras línguas. Entretanto, não basta tão somente oferecer uma LE na grade curricular: é necessário primar por seu ensino com qualidade, oferecendo subsídios para sua prática efetiva (MACIEL e OLIVEIRA, 2011).

Desse modo, este estudo torna-se relevante no âmbito social uma vez que, apresentando a realidade do processo de ensino-aprendizagem de Espanhol em escolas públicas do DF, abre espaço para a reflexão de como tal processo tem ocorrido, visando contribuir para a melhoria do ensino dessa LE em escolas públicas em todo o país, visto que os dados aqui apresentados poderão levar a uma possível intervenção nos órgãos responsáveis pela implantação da língua espanhola no Brasil.

\footnotetext{
${ }^{5}$ Essa carta foi elaborada pelos participantes do II Encontro Nacional sobre Política de Ensino de Línguas Estrangeiras (ENPLE), realizado em setembro de 2000, na cidade de Pelotas - RS. Enviado ao Ministério de Educação (MEC), de modo que as autoridades competentes conhecessem a realidade do ensino de línguas no Brasil a fim de formar uma política nacional de ensino de línguas, esse documento contém importantes considerações e propostas para o ensino de LEs. Seu teor completo está disponível em: <http://www.ipol.org.br/ler.php?cod=132>. Acesso em: 26 nov. 2013.
} 


\title{
1.2.2 Relevância acadêmica: Estudos representativos
}

Segundo Paraquett (2012), a Linguística Aplicada (doravante LA) é uma disciplina de prestígio e poder na resolução de questões políticas relativas à educação no Brasil. Todavia, a autora acrescenta que ainda há pouquíssimos pesquisadores da área de Espanhol. Assim, ao discorrer sobre pesquisas com foco no processo de ensino-aprendizagem de língua espanhola, Paraquett (IBIDEM, 2012, p. 237, grifo meu) destaca que

\begin{abstract}
[...] todas as pesquisas que colaboram para o ensino de espanhol, no que tange a procedimentos adequados, seja na seleção ou produção de materiais didáticos; na interação entre alunos e professores; na definição de estratégias para a compreensão e produção de textos; na vinculação com as políticas públicas da educação básica; na efetivação de um ensino que tenha fins específicos; ou na formação de professores, todas são pesquisas próprias à LA.
\end{abstract}

Com base no fragmento acima, esta pesquisa contribui para as investigações em LA que têm voltado sua atenção às políticas públicas que dizem respeito à educação, assim como às políticas linguísticas. Ainda que nos dias de hoje o interesse por essas temáticas seja crescente no âmbito investigativo, coincido com a Carta de Londrina (2014) ${ }^{6}$, ao considerar que os estudos e pesquisas brasileiros têm focalizado de maneira insuficiente as políticas referentes ao ensino de línguas, uma vez que o ensino de uma LE não mais se configura somente como um problema metodológico, mas também como um problema político.

Leffa (2005) explica a distinção entre esses dois tipos de problema: um problema metodológico é visto ao se olhar apenas para dentro da sala de aula, ao passo em que um problema se torna político quando se lança o olhar para além da sala de aula: "Basicamente, a ênfase no problema político preocupa-se com as repercussões lá fora daquilo que é feito dentro da sala de aula e vice-versa” (IBIDEM, 2005, p. 203).

Portanto, visando conhecer os trabalhos em nível de pós-graduação que objetivaram discorrer sobre o ensino de Espanhol como um problema político, dedicando-se a pesquisar a realidade da implantação da Lei 11.161/2005, efetuei um levantamento de bibliografia por meio de pesquisa online na Biblioteca Digital Brasileira de Teses e Dissertações (doravante

\footnotetext{
${ }^{6}$ Essa carta foi elaborada pelos participantes do I Fórum da Profissionalização Docente, realizado em setembro de 2014 na cidade de Londrina - PR, no qual foram abordados os seguintes temas: História, Políticas e Ética. Seu teor completo está disponível em: 〈http://www.uel.br/eventos/forumdocente/>. Acesso em: 10 nov. 2014.
} 


\section{BDTD) e no Banco de Teses da CAPES ${ }^{7}$.}

Em minha pesquisa realizada na BDTD, utilizando como elemento de busca os termos: "Espanhol”, "política linguística" e "11.161", somente um ${ }^{8}$ estudo contemplou esses três termos de busca. Decidi então, delimitar a busca nos termos "Espanhol" e "11.161", da qual resultaram 16 estudos. Desses 16 estudos, apenas um teve como intuito descrever a realidade por trás da implantação da Lei 11.161/2005: Maciel (2011). Essa pesquisa foi realizada na região sul do Brasil, na Universidade Estadual de Ponta Grossa - PR.

De igual modo, realizei a mesma busca no Banco de Teses da CAPES com os três termos iniciais ("Espanhol", "política linguística" e "11.161"), que também resultou em somente um estudo ${ }^{9}$ defendido na Universidade do Sul de Santa Catarina. Da mesma forma, ao alterar a busca para somente "Espanhol" e "11.161", o Banco de Teses da CAPES ofereceu 9 trabalhos realizados nos programas de Pós-graduação brasileiros. Dos 9 estudos apresentados, somente mais uma investigação dedicou-se à realidade da implantação do Espanhol: Teran (2012), sendo defendida também na região sul do Brasil (Universidade Regional de Blumenau).

Com base nos dados encontrados, notei que apesar de já ter se passado quase 10 anos da sanção da Lei 11.161/2005, a realidade da implantação do Espanhol no Brasil ainda é uma temática recente e carente de investigações, pois, ao buscar em dois importantes bancos de teses e dissertações, tive conhecimento de apenas dois estudos que contemplaram essa temática ${ }^{10}$. Também percebi (não somente ao pesquisar nos bancos de teses, mas também em meu levantamento bibliográfico) que a maioria esmagadora de pesquisas relacionadas ao ensino de Espanhol e sua implantação foram realizadas na região sul do país, demonstrando que ainda pouco se pesquisou sobre como tem ocorrido o ensino de língua espanhola nas demais regiões brasileiras.

Portanto, considerando tais observações, a presente investigação se torna relevante academicamente por dedicar-se a um tema recente, carente de investigações e pouco pesquisado não somente na região centro-oeste, mas em todo o país.

\footnotetext{
${ }^{7}$ A pesquisa online nos dois bancos de teses (BDTD e CAPES) foi realizada em dois momentos: inicialmente, em junho de 2014 e posteriormente, atualizada em outubro de 2014.

${ }^{8}$ Cf. Jantuta (2010). Contudo, este estudo dedicou-se à análise dos efeitos das ações políticas educacionais públicas sob uma perspectiva enunciativa, e não à realidade da implantação do Espanhol.

${ }^{9}$ Cf. Oliveira (2012). Entretanto, o foco desta pesquisa foi a análise discursiva das políticas linguísticas voltadas para o ensino de língua espanhola, e não a realidade de sua implantação.

${ }^{10}$ Os demais estudos abordaram temas diversos, como: formação de professores; crenças, aquisição de segunda língua, memória discursiva e percurso histórico do ensino de Espanhol no Brasil, avaliação, centros de línguas e manuais.
} 


\subsubsection{Relevância pessoal e motivação da pesquisadora}

Minha história de amor pela língua espanhola vem desde o berço. Natural de Uruguaiana - RS, fronteira entre Brasil e Argentina, cresci rodeada pelo Espanhol. Meus pais eram comerciantes e suas lojas voltadas para o público argentino. Logo, havia o contato com o Espanhol; sua sonoridade, beleza e rica cultura fizeram parte de minha infância até minha adolescência, pois, quando eu tinha 13 anos, minha família mudou-se para a capital Federal.

Em Brasília continuei a crescer. Cursei meu Ensino Médio em uma escola pública de Taguatinga, e foi durante esse tempo que comecei a sonhar com a entrada em uma universidade pública, tendo muitas dúvidas sobre o curso que escolheria para minha futura profissão: eu sonhava com um ofício no qual eu pudesse fazer diferença na vida das pessoas, do qual eu pudesse me orgulhar, e ser plenamente feliz. Eu tinha a esperança de contribuir para um mundo melhor através da minha profissão, e ainda hoje, em mim esse desejo é latente. Assim, ao olhar para minhas preferências e aptidões, decidi cursar Letras - Espanhol, uma vez que eu me identificava e admirava o ofício de "ser professor" e era apaixonada pela língua espanhola.

Muitos foram os percalços para que o sonho daquela adolescente de anos atrás se tornasse real: eu, uma aluna de escola pública, consciente de que em minha realidade escolar eu era desprovida de um ensino efetivo, estudava sozinha por horas a fio. Durante aquele período, várias foram as idas à biblioteca; as manhãs, tardes, noites, as garrafas de café, as lágrimas, as orações, as palavras de incentivo bem como as de desencorajamento.

Certo dia, com 15 anos, pedi auxílio de um professor de exatas para estudar para o vestibular. Esse professor me olhou, e tão somente disse: "Desista disso, universidades públicas não são para alunos da escola pública como você". Essas palavras rasgaram meu coração. Esse episódio marcou minha vida, pois naquele dia, decidi mais uma vez entregar aquele sonho a Deus e fazer a minha parte. Não somente isso, eu disse a mim mesma que mostraria a capacidade do aluno da escola pública e quando eu me tornasse uma professora, jamais seria como esse professor.

Assim, aos 16 anos fui aprovada no Programa de Avaliação Seriada (PAS) ${ }^{11}$ da Universidade de Brasília (UnB), iniciando minha formação como professora de Espanhol.

\footnotetext{
${ }^{11}$ O Programa de avaliação seriada da Universidade de Brasília (UnB) é uma forma de entrada na Universidade, consistindo na realização de uma prova ao término de cada ano letivo do Ensino Médio. Mais informações em: $\langle$ http://www.cespe.unb.br/pas/PAS oque.aspx $>$. Acesso em 02 de outubro de 2013.
} 
Aos 19 anos iniciei minha prática docente, e aos 20 anos me formei na UnB e iniciei meu trabalho na Secretaria de Educação do Distrito Federal como contrato temporário. Foi nessa época que tive contato com o ensino regular em escolas públicas, ao lecionar Espanhol em uma escola de Ensino Médio na RA Ceilândia. Nesse momento, as palavras do filósofo chinês Confúcio tornaram-se mais que reais em minha vivência: "escolha um trabalho que você ame e não terás que trabalhar um único dia em sua vida”. Me apaixonei por meu ofício, vendo-o como de fato, uma vocação, algo feito com - e por - amor. Tomei amor pelo ensino regular e pela realidade da escola pública e, quanto mais me apaixonava ao olhar para meus alunos e para a aluna que também fui, mais desejava que o ensino na escola pública fosse de qualidade. Porém, minhas condições como professora não eram as melhores: nessa escola eu trabalhava apenas 20h, mas lecionava Espanhol a 16 turmas com as aulas de Espanhol tendo a duração de 50 minutos.

Realizando mais um sonho, em 2012 retornei como professora de Espanhol à escola de Taguatinga na qual cursei meu ensino médio e me formei, e ali pude vivenciar momentos maravilhosos que me auxiliaram sobremaneira em minha prática docente e na construção do perfil de professora que hoje sou.

Todavia, mais uma vez, minha realidade de ensino era difícil: eu trabalhava 40h, ministrava aulas de Espanhol, Português e Parte diversificada (doravante PD), tinha 20 turmas e minhas aulas de Espanhol duravam apenas 50 minutos. Eu percebia o quão prejudicial era essa realidade não somente para o professor, mas para o aluno, que reclamava por não poder ter mais aulas de Espanhol. Tal realidade me frustrava, pois, ainda que eu me esforçasse, ensinava de forma simplificada uma língua extremamente rica, não proporcionando aos meus alunos aulas diferenciadas, com qualidade real. Portanto, atrelada às demais necessidades que eu percebia nesse ensino (carência de matérias; formação docente inadequada, falta de interesse por parte dos alunos e das instâncias governamentais, entre outros), passei a me questionar sobre essa realidade do ensino de Espanhol em escolas públicas, percebendo as mesmas indagações nas escolas por onde eu passava, nos professores com os quais eu conversava, nos alunos a quem eu ensinava.

Com base nisso, ao entrar no mestrado acadêmico no Programa de Pós-graduação em Linguística Aplicada (PPGLA) da Universidade de Brasília, considerando minha trajetória e minha vivência como professora de Espanhol em escolas públicas do DF, não tive dúvidas sobre o tema de minha pesquisa. Hoje me sinto extremamente realizada por ter a honra de contribuir para o processo de ensino-aprendizagem de Espanhol em escolas públicas do 
Brasil, sonhando com o momento em que verei a realidade do ensino de Espanhol transformada, e nossos alunos da escola pública tendo acesso a um ensino digno. Portanto, Rubem Alves (1980, p. 21, grifo meu) explicitou bem minha motivação ao realizar esta pesquisa quando afirmou: "Diz-nos Freud que a questão decisiva não é a compreensão intelectual, mas um ato de amor".

\subsection{Objetivos e Perguntas de pesquisa}

Como mostraram as considerações e a justificativa, motivos como minha trajetória, formação e experiência como professora de Espanhol em escolas públicas, levaram-me a pesquisar e a refletir sobre a realidade do ensino de Espanhol em escolas públicas do DF após a implantação da Lei 11.161/2005.

Dessa forma, os objetivos dessa investigação são:

1. Descrever como ocorreu e tem ocorrido a implantação da Lei 11.161/2005 em duas Regiões Administrativas do DF: Taguatinga e Paranoá,

2. Analisar se as realidades de ensino com a implantação da Lei 11.161/2005 nestas duas regiões são semelhantes ou se diferem,

3. Apresentar os descompassos presentes nesta implantação, constatando as limitações e necessidades deste ensino.

Com o intuito de alcançar os objetivos propostos, este estudo se propõe a responder as seguintes perguntas:

1. De que maneira tem ocorrido o processo de ensino-aprendizagem de Espanhol em escolas públicas do Distrito Federal após a implantação da Lei 11.161/2005?

2. Atualmente, quais as limitações presentes no processo de ensino-aprendizagem de Espanhol em escolas públicas do Distrito Federal?

2.1 De que forma a carga horária destinada à disciplina influencia no processo de ensino-aprendizagem de Espanhol?

3. Que medidas podem ser tomadas para melhorar o processo de ensinoaprendizagem de Espanhol em escolas públicas do Distrito Federal? 


\subsection{Organizando a Dissertação}

A presente investigação está organizada em quatro capítulos. Neste capítulo, introduzi a pesquisa ao apresentar sua contextualização; justificativa, assim como os objetivos e as perguntas de pesquisa que nortearam este estudo.

No segundo capítulo apresento a fundamentação teórica que serviu de sustentação para esta pesquisa. Introduzo esse capítulo ao lançar mão de uma Linguística Aplicada crítica, autorreflexiva, problematizadora e interventiva. Posteriormente, discorro sobre os conceitos de política pública, educacional e linguística e as implicações de cada definição. Após essas definições, por meio de um breve panorama histórico realizo uma retrospectiva acerca do ensino de Espanhol em solo brasileiro ao analisar momentos importantes referentes ao ensino dessa língua no Brasil. Por fim, dedico-me à Lei 11.161/2005 e suas repercussões.

No terceiro capítulo apesento os procedimentos metodológicos desta investigação, que incluem a abordagem da pesquisa; os métodos utilizados, instrumentos de coleta de dados e seu modo de análise. Em seguida, apresento o cenário, participantes da pesquisa, aspectos éticos e o período de coleta de dados.

O quarto capítulo diz respeito à análise e discussão dos dados obtidos, sendo este capítulo subdividido em (1) análise de dados gerais e (2) análise de dados específicos.

A última parte deste estudo fica reservada para as considerações finais, nas quais retomo as perguntas de pesquisa; apresento as contribuições da investigação, assim como as limitações do estudo e as sugestões para pesquisas futuras.

Por fim, é válido ressaltar que esta investigação não visa trazer generalizações (uma vez que é uma amostra de duas realidades do ensino de Espanhol em escolas públicas) e que, ainda que as realidades, êxitos e necessidades sejam muitas vezes semelhantes entre escolas, regiões e estados, o ensino de Espanhol em escolas públicas no Brasil pode apresentar realidades diferentes.

À luz das considerações feitas, a seguir apresento o construto teórico que serviu de pilar para esta pesquisa. 


\section{CAPÍTULO 2 \\ REFERENCIAL TEÓRICO}

“Todo ato de pesquisa é um ato político."

Rubem Alves (1980, p. 79)

\subsection{ATRIBUINDO À PESQUISA UMA DIMENSÃO CRÍTICA}

A História decorre a longos passos. Os anos avançam. As gerações mudam. Novas visões emergem do campo científico. Paradigmas são quebrados; mudados, revistos, abandonados, substituídos. Perspectivas se alteram, inovações são evocadas. O mundo opera transições, e assim é possível perceber o fato de "existir" como "existir sempre em movimento, em meio a oscilações entre continuidades e rupturas" (FABRÍCIO, 2006, p. 46).

Ao passo em que transformações, atravessando épocas, são operadas no âmbito investigativo, algumas características permanecem. Tais características se perpetuam com o passar do tempo, e por vezes, criam raízes profundas nos solos da investigação.

Uma dessas características, presente em muitos pesquisadores das ciências sociais desde os pioneiros até os contemporâneos -, é o desejo de "inaugurar" um novo paradigma social e político. A possibilidade de trazer à existência novas epistemes salta aos olhos, e, segundo Moita Lopes (2006b, p. 85), tal anseio se configura na "grande preocupação" de muitos pesquisadores. De fato, inaugurar novos paradigmas, perspectivas, e assim, teorias postuláveis, é louvável e digno de reconhecimento, pois nos referimos a frutos colhidos após árduo preparo e plantio, logo, nada mais justo que uma colheita exitosa.

Entretanto, é necessário que o pesquisador vá além, e se questione sobre suas reais motivações e intentos ao produzir conhecimento cientifico. Em concordância com o pensamento foucaultiano, é preciso sempre interrogar-se sobre nossos próprios modos de pensar. Ao interrogar-se sobre suas próprias formas de pensar, o pesquisador desvencilha-se de suas autoconcepções e se abre para práticas realmente problematizadoras (PENNYCOOK, 2006).

Com base nas considerações acima, compreendo a importância e necessidade da "Pesquisa crítica". Esta pesquisa crítica não está relacionada a visões negativas ou pejorativas, mas à compreensão de que as formas de conhecimento e de saber são ideológicas, e levam em conta a necessidade de considerar a quem pertencem os interesses contemplados em nossos esforços investigativos. Trata-se da compreensão de que, na produção do conhecimento, "nossas práticas discursivas não são neutras, e envolvem escolhas (intencionais ou não) 
ideológicas e políticas ${ }^{12}$, atravessadas por relações de poder, que provocam diferentes efeitos no mundo social” (FABRÍCIO, 2006, p. 48, grifo meu).

Dessa forma, compreendendo que nenhum conhecimento pode ser concebido como apolítico ou isento de interesse, e, concebendo a pesquisa como uma forma de construir e produzir efeitos no mundo social, bem como de "articular e (des)construir sentidos designados pelos discursos de autoridade, paradigmáticos, legitimados pelos exercícios de subjugação por aqueles que se atribuem o direito de distribuírem o sentido das palavras" (BOHN, 2005, p. 11), percebo no linguista aplicado o papel de intervir nas práticas sociais: uma poderosa voz que não pode calar-se e nem omitir-se, tendo em vista a possibilidade de através de seu discurso construir e desconstruir sentidos, com a compreensão sempre presente e motivadora de que suas práticas discursivas geram impactos e transformações no mundo social. Como bem elucidou Moita Lopes (2011, p. 21, grifo meu), ao responder à questão "Como não separar política de pesquisa?”

\begin{abstract}
Em um mundo atravessado pelo poder de forma multidirecionada e que apresenta desafios para uma série de significados sobre quem somos, que constituíram o cerne da modernidade, é crucial pensar formas de fazer pesquisa que sejam também modos de fazer política ao tematizar o que não é tematizado e ao dar voz a quem não tem.
\end{abstract}

É neste pensamento que este trabalho procurará situar-se em um campo crítico; autorreflexivo, problematizador, interventivo, buscando novos olhares, sugestões e melhorias para o futuro, baseando-se em uma Linguística Aplicada: Indisciplinar, ideológica e mestiça (MOITA LOPES, 2006); de desaprendizagem (FABRÍCIO, 2006), transgressiva e crítica (doravante LAC), (PENNYCOOK 1998, 2006), e crítica (RAJAGOPALAN, 2003, 2006), ou seja, uma "Linguística Aplicada que seja mais sensível às preocupações sociais, culturais e políticas (...), que procure sempre tanto criticar quanto transformar; que busque envolver-se num projeto moral e político que possibilite a realização de mudanças" (PENNYCOOK, 1998, p. 23, grifo meu).

\footnotetext{
12 Apoiando-me em Rajagopalan (2003), entendo que essas escolhas ideológicas e políticas ao produzir conhecimento científico nas ciências sociais e, mais especificamente, na LA, constituem-se na compreensão da linguagem como um "importante palco de intervenção política", onde as injustiças sociais são manifestadas e onde se travam constantes lutas. Logo, "a consciência crítica começa quando se dá conta do fato de que é intervindo na linguagem que se faz valer suas reinvindicações e suas aspirações políticas. Em outras palavras, toma-se consciência que de trabalhar com a linguagem é necessariamente agir politicamente, com toda a responsabilidade ética que isso acarreta" (RAJAGOPALAN, 2003, p. 125).
} 


\subsection{2 (Re) definindo o objeto de investigação da Linguística Aplicada}

Durante muito tempo, definir o objeto de estudo da LA configurou-se como uma tarefa difícil. Trata-se de uma ciência que, nascida à sombra da Linguística, voltada inicialmente para o ensino de LEs e carregando fortes traços positivistas, atravessou um longo caminho para vivenciar novos ares no que hoje pode ser definido como "contemporaneidade ${ }^{13}$ ".

Após anos de debates e acirrados embates, parece existir um consenso no tocante ao objeto de investigação da LA (MENEZES, SILVA e GOMES, 1998). A LA configura-se como uma ciência que tem como objeto de investigação a linguagem como prática social, ocupando-se de um problema real de uso de linguagem colocado na prática dentro ou fora do contexto escolar (ALMEIDA FILHO, 1991). De maneira prática, tem como objetivo "criar inteligibidade sobre problemas sociais em que a linguagem tem um papel central" (MOITA LOPES, 2006a, p. 14). Contudo, analisando o percurso histórico da trajetória da LA, é possível concluir que este pensamento nem sempre existiu da forma como hoje é constituído, como ilustrarei a seguir.

\subsubsection{Os traços da Linguística tradicional}

A LA tradicional; teórica, fortemente ligada ao Behaviorismo, Estruturalismo e, sobretudo, ao Positivismo, inicialmente produziu pesquisadores distantes das realidades vividas por cidadãos comuns, cada vez mais "ausentes das discussões acerca de assuntos de grande relevância para os leigos" (RAJAGOPALAN, 2006, p. 154). O que se percebia era uma LA presa à diferença de LA e a aplicação da Linguística; comprometida com a objetividade, dotada de uma concepção a-política e a-histórica de linguagem, possuidora de um sujeito homogêneo situado em um vácuo social ao ter sua sócio-história apagada (MOITA LOPES, 2006). Uma LA restrita, envolvida por uma visão reducionista e unidirecional, restringida ao simplismo.

Para Rajagopalan (2006), o desinteresse dos linguistas por assuntos relacionados à

\footnotetext{
13 Aqui, compartilho do conceito de Hilário Bohn (2005, p. 12) para definir contemporaneidade: “A contemporaneidade é uma caminhada, não há pontos de chegada, mas apenas momentos de retomada de fôlego para continuar a trilhar o caminho que tem nas pegadas já percorridas os sentidos do significar do novo". Logo, compreendo a contemporaneidade como novos ares, porém provenientes de ventos anteriormente soprados. Trata-se do emergir de novas necessidades e possibilidades, levando-se em consideração o peso do passado "na busca de soluções ousadas e inovadoras" (RAJAGOPALAN, 2006).
} 
política linguística ${ }^{14}$ e aos muitos temas de interesse prático pôde ser atribuído à neutralidade do cientista no tocante às questões de ordem ética, e consequentemente, política. Remontando ao Positivismo", o linguista se afastou das "questões práticas relativas à linguagem, sobretudo daquelas que envolviam juízos de valor, como é o caso da política linguística" (RAJAGOPALAN, 2006, p. 155). Assim, comprometidos com a neutralidade, os linguistas não intervinham nas questões éticas, por essas envolverem valores. O interesse do linguista nesse momento estava relacionado ao que o nativo dizia $\mathrm{em}$ sua língua. O que o nativo dizia sobre sua língua não interessava ao pesquisador, podendo até mesmo, "atrapalhar" o rumo da pesquisa. (IBIDEM, p. 156).

Assim, esses pesquisadores compreendiam que o conhecimento nada tinha a ver "com o modo como as pessoas vivem suas vidas cotidianas, seus sofrimentos, seus projetos políticos e desejos" (MOITA LOPES, op. cit., p. 87). Almejava-se o "saber pelo saber", satisfazendo a criatividade e o ego dos tão somente produtores de teorias (VIEIRA, 2009), desinteressados na vivência real das pessoas de carne e osso. O predomínio deste pensamento resultou "no desvinculamento desses estudos das questões históricas, sociais, culturais ou políticas” (PENNYCOOK, 1998, p. 26). Não havia espaço para se considerar questões relativas a poder e desigualdade.

Ironicamente, com o tempo notou-se que "muito do que se chama linguística insiste em ignorar o que as pessoas no cotidiano pensam sobre a linguagem, embora igualmente insista em produzir conhecimento sobre a vida delas ou lhes indicar ações políticas" (MOITA LOPES, 2006b, p. 88), indicando que essa LA tragada pela visão ocidentalista perdurou durante muito tempo, produzindo conhecimento acerca da vida de pessoas em seus cotidianos, e ainda subsiste em determinados âmbitos da academia.

Contudo, o desejo de mudança e a necessidade de evoluir, por serem características essenciais do ser humano (LEFFA, 2005), também chegaram aos solos da LA, quando o pensamento positivista passou a ser cada vez mais questionado. Esses questionamentos vieram, inclusive, das ciências exatas ou da natureza. Seus próprios cientistas já confessavam com toda franqueza que "o seu trabalho também tem fortes conotações ideológicas e políticas" (RAJAGOPALAN, 2003, p. 124).

\footnotetext{
${ }^{14}$ O conceito de "Política Linguística" será trabalhado de forma detalhada ainda neste capítulo, na próxima seção.

${ }^{15}$ A influência e as características do pensamento positivista nas ciências sociais serão elucidadas no capítulo 3 desta dissertação, ao situar a necessidade de um paradigma qualitativo nas ciências sociais, e consequentemente, o surgimento da pesquisa qualitativa.
} 
De fato, "as áreas de investigação mudam quando novos modos de fazer pesquisa, tanto do ponto de vista teórico quanto metodológico, são percebidos como mais relevantes para alguns pesquisadores" (MOITA LOPES, 2006a, p. 16). Sendo assim, nesse momento, muitas das questões que antes interessavam aos linguistas aplicados "mudaram de natureza, ou se complexificaram, ou deixaram de existir" (MOITA LOPES, 2011, p. 19), cabendo ao pesquisador escolher os caminhos a seguir.

Novos paradigmas estavam surgindo. O emanar dessas novas visões e maneiras de fazer e teorizar LA não implicou em uma nova verdade, tão pouco em uma "nova escola de LA", mas em "alternativas para a pesquisa em nosso campo, que refletem visões de mundo, ideologias, valores" (MOITA LOPES, op. cit., p. 21, grifo meu). Não se tratava de uma "nova receita", mas de uma ampliação de possibilidades (PENNYCOOK, 1998). Os linguistas aplicados que se voltaram para teorias contemporâneas, buscando atribuir à LA valores críticos para intervir na prática social, tão somente reavaliaram e repensaram suas ações dentro de contextos sociais, culturais e políticos, "mudando a direção, sem deixar o barco".

A LA rumava à descoberta de novos caminhos: novos objetos, novos métodos, novos recortes teóricos (ROJO, 2006), mas principalmente, uma nova autoconcepção, uma reavaliação, uma reconstrução de identidade: emergia uma Linguística Aplicada crítica e interventora.

\subsubsection{O caráter da LA crítica: Intervindo politicamente na prática social}

As novas tendências em LA foram nomeadas de diversas formas ${ }^{16}$, por diversos pesquisadores. As diferenças consistem apenas em questões de nomenclatura, pois a visão evocada é a mesma: uma LA atenta a teorizações extremamente relevantes nas ciências sociais e nas humanidades.

Esta nova concepção de LA considera o social, o político e o histórico, aspectos antes denominados "extralinguísticos" (KLEIMAN, 1998, p. 48), e reconstrói o sujeito da LA antes uno e homogêneo - como historicamente situado, possuidor de natureza heterogênea, fragmentada, contraditória e fluída.

Moita Lopes (2006), em sua obra "Por uma Linguística Aplicada Indisciplinar", nomeou esta nova visão da LA como uma LA ideológica, mestiça e indisciplinar: um projeto

\footnotetext{
${ }^{16}$ Nesta dissertação, trabalho com as visões dos seguintes autores: Fabrício (2006): LA de desaprendizagem; Moita Lopes (2006): Linguística Aplicada Indisciplinar, ideológica e mestiça; Pennycook $(1998,2006)$ : LA transgressiva e crítica (LAC), e Rajagopalan (2003, 2006): LA crítica.
} 
de renovação e reinvenção, que busca problematizar os modos de produzir conhecimento: uma LA que dialoga com outros campos e áreas do saber, que tenha algo a dizer ao mundo e à vida contemporânea, na qual é "essencial que a LA se aproxime de áreas que focalizam o social, o político e a história" (MOITA LOPES, 2006b, p. 96). Uma LA que atua em campos "híbridos", alargando seus espaços e aproximando-se das fronteiras disciplinares, tendo em vista a permeabilidade crescente entre as áreas de conhecimento, uma vez que uma única disciplina ou área de investigação, sozinha, já não "dá conta" de um mundo globalizado e fluído, que enfrenta transformações de natureza histórica; econômica, cultural, tecnológica e política. Dessa forma, a LA se configura como um "espaço de múltiplos centros" (RAMPTON, 2006).

No mesmo pensamento, Fabrício (2006) traz à tona uma LA de desaprendizagem, pois esta ousa pensar de modo diferente, além dos paradigmas consagrados, que necessitariam ser desaprendidos para se compreender o mundo atual: uma LA que "se constitui problematizadora envolvida em contínuo questionamento das premissas que norteiam nosso modo de vida; que percebe questões de linguagem como questões políticas" (FABRÍCIO, 2006, p. 60).

Rajagopalan (2003), em seu livro "Por uma Linguística crítica", nos traz à reflexão que a criticidade atribuída à linguística constitui-se na compreensão de que a questão linguística e a questão política seriam uma só, na ideia de que ao falar uma língua, já nos envolvemos em uma atividade eminentemente política (IBIDEM, p. 33).

Para o autor, a linguística crítica $^{17}$ se apresenta como um movimento fortemente consolidado e que veio para ficar, com adeptos nos quatro cantos do mundo, pois cada vez mais pesquisadores percebem que não há como se esquivar de sua responsabilidade ética (IBIDEM, p. 128). Ao contribuir para a melhoria das condições de vida dos setores menos privilegiados, o linguista vai recuperando o seu verdadeiro papel enquanto cientista social.

Pennycook (1998, 2006) apresenta a LA com um caráter transgressivo. A LAC (Linguística Aplicada Crítica), de natureza sempre problematizadora e autorreflexiva, tem como dever examinar a base ideológica do conhecimento que produz. O autor afirma que como educador e linguista aplicado, sente que seu projeto deva ser, sempre e simultaneamente, pedagógico e político. Logo, percebe a necessidade de se reinstaurar o político e o ético nos trabalhos acadêmicos, bem como a necessidade de o linguista aplicado assumir projetos políticos e morais, na construção da LA como um "projeto crítico"

\footnotetext{
${ }^{17}$ Assim como Rojo (2013), aqui tomo o termo "Linguística crítica" como sinônimo de LA.
} 
(PENNYCOOK, 1998, p. 44). Por fim, esta LA constituída de criticidade, tem buscado produzir resultados de pesquisa que "sejam postos a serviço da humanidade" (CELANI, 2008, p. 32).

\subsubsection{Entre a pesquisa e o sonho: LA, um lugar de "ensaio da esperança"}

Buscando novas alternativas para o futuro, bem como "ganhos a práticas sociais e a seus participantes, no sentido de uma melhor qualidade de vida" (ROJO, 2006, p. 258, grifo meu), é tempo de reinventar a vida social, engajando-se em práticas que tragam melhorias. Se o impacto de nossas pesquisas for considerável, daremos à LA a "visibilidade necessária para ganhar os espaços políticos que reivindicamos” (KLEIMAN, 1998, p. 66).

Coincido o pensamento de Moita Lopes (2006b, p. 104, grifo meu), quando afirma que "é o sonho que nos faz pensar em alternativas para as questões que se apresentam nas várias esferas de nossas vidas". Portanto, nesse sentido, - como aluna proveniente da escola pública, professora de Espanhol e linguista aplicada -, é o meu grande sonho ver a transformação da realidade do ensino de Espanhol nas escolas públicas brasileiras, bem como o desejo de suscitar uma maior reflexão sobre os passos e descompassos da implantação da Lei 11.161/2005 no DF através da comparação de duas realidades contraditórias, as quais me motivam a tomar partido da LA em sua natureza crítica.

Como Leffa (2005), percebo o papel de agente político atribuído ao educador, e a necessidade de um posicionamento engajado, reflexivo e interventivo. Desse modo, ainda que para muitos este posicionamento crítico se configure no ecoar de sussurros utópicos, com o pensamento voltado para o futuro, concebo a LA como "lugar de ensaio da esperança" (MOITA LOPES, op. cit., p. 104). Portanto, aqui tomo a ousadia de compreender o campo do saber e a produção do conhecimento científico como um ambiente no qual seja possível sonhar, e através de nossas práticas discursivas, contribuir para que um dia estes sonhos se tornem reais.

\subsection{POLÍtica, POLÍtica Pública, Política EdCACIONAL E POLÍtica LINGUÍSTICA}

"Estamos diante de um gesto político claro, e, sobretudo, de um gesto de política linguística..." (MEC/SEB, 2006, p. 128, sobre a Lei 11.161/2005). 
A implantação da Lei 11.161/2005 em solo brasileiro, além de apresentar-se como um ato político, também se configura como:

1) Uma política pública,

2) Uma política educacional,

3) Uma política linguística.

Nesta sessão abordarei os três termos acima com o objetivo de conceituá-los e melhor compreendê-los, refletindo sobre suas características e desdobramentos. Para considerar cada um desses termos e refletir sobre suas implicações, é válido recorrer, de forma breve, à definição do termo "Política".

De acordo com o Dicionário de Política, "política" diz respeito a um "derivado do adjetivo originado de pólis (politikós), que significa tudo o que se refere à cidade e, consequentemente, o que é urbano, civil, público, e até mesmo sociável e social" (BOBBIO et al, 2000, p. 954).

Para o antigo pensador grego Aristóteles, a política seria um desdobramento da ética (RAJAGOPALAN, 2013), devendo a política obedecer à ética e estar de acordo com seus princípios.

Segundo Bohn (2000, p. 122), a conceituação de política está intimamente ligada à noção de poder, isto é, “quem faz política exerce o poder": ao fazer política, o ser humano exerce poder sobre outro ser humano ou sobre grupos sociais específicos, a fim de obter alguma forma de benefício pessoal ou coletivo.

Rajagopalan $(2003,2013)$ associa a política à noção de escolha, pois, para este autor, todo gesto de cunho político envolve uma escolha entre diferentes vicissitudes.

Agrupando as referidas definições a um pensamento comum e levando em consideração minhas reflexões pertinentes a esta temática, percebo que política diz respeito à participação de pessoas livres nas decisões referentes à pólis, ou seja, à cidade. Tais decisões, visando o bem comum (pois se referem ao público e social), devem basear-se em um campo ético, no qual relações de poder são estabelecidas, e consequentemente, escolhas necessitam ser feitas.

\subsubsection{Política Pública}

De acordo com Lima (2012), os estudos sobre Políticas Públicas são ainda muito 
recentes no Brasil, visto que há muita divergência no campo conceitual no tocante a este tema, e ainda há uma escassez muito grande na tradução da literatura relacionada a esse assunto para a língua portuguesa (SOUZA, C., 2006). Tais afirmações demonstram como o interesse pelas Políticas Públicas deu-se de forma tardia no Brasil, tendo nas últimas décadas, ressurgido a importância e visibilidade deste campo de estudos, tendo em vista o progresso das condições democráticas ao redor do mundo.

Como já visto, etimologicamente a palavra política, de origem grega, se refere à participação das pessoas nas decisões relativas à pólis (cidade). Já à palavra pública, de origem latina, atribui-se a ideia de "povo", "do povo". Logo, uma forma de compreender política pública é a ideia de o povo engajado na participação das decisões relativas à cidade.

Adão Oliveira (2010) afirma que historicamente essa participação deu-se de maneiras distintas, podendo ocorrer de forma direta ou indireta, através da representação. De todo modo, para o acontecimento de uma política pública, sempre haverá a necessidade de um agente: o Estado, sendo este, em cada um dos três níveis de governo (municipal, estadual e federal $^{18}$ ), o principal responsável por garanti-las. Assim, percebe-se que as Políticas Públicas repercutem na economia e na sociedade, "daí porque qualquer teoria de política pública precisa também explicar as inter-relações entre Estado [agente], política, economia e sociedade [pólis]" (SOUZA, C., op. cit., p. 6).

Cabe destacar que a "sociedade civil, ou melhor, o povo, não é responsável direto e nem agente implementador de políticas públicas. No entanto, a sociedade civil, o povo, faz política" (OLIVEIRA, Adão, 2010). Além de fazer política, a sociedade civil é diretamente afetada pelas ações do Estado.

Historicamente, as Políticas Públicas surgiram como um subcampo da Ciência Política, em meados de 1960 e 1970. Segundo Celina Souza (2006), a área de Políticas Públicas contou com quatro "grandes pais fundadores": H. Laswell, H. Simon, C. Lindblom e D. Easton. A autora (2006, p. 7) conceitua Política Pública como

[...] o campo do conhecimento que busca, ao mesmo tempo, "colocar o governo em ação" e/ou analisar essa ação (variável independente) e, quando necessário, propor mudanças no rumo ou curso dessas ações (variável dependente). A formulação de políticas públicas constitui-se no estágio em que os governos democráticos traduzem seus propósitos e plataformas eleitorais em programas e ações que produzirão resultados ou mudanças no mundo real.

\footnotetext{
18 A Constituição de 1988 ampliou a descentralização político-administrativa, atribuindo competências a esses referidos níveis de governo.
} 
Portanto, as políticas públicas são formas de efetivar direitos através da ação do governo de forma interventiva na realidade social, bem como a análise dessas ações, no intuito de melhorá-las.

É válido lembrar que de nada adiantam direitos previstos em legislação (como decretos e leis), se não houver políticas públicas que efetivem esses direitos. Caso não haja essas políticas, tais direitos não passarão de boas intenções que não foram efetivadas.

O Instituto Pólis (Instituto de Estudos, Formação e Assessoria em Políticas Sociais), na revista "Repente" de publicação on-line, em dezembro de 2006 (p. 3) publicou um artigo denominado "Política Pública como garantia de direitos", no qual apresentou os passos, o ciclo de desenvolvimento de uma política pública:

1) A identificação de uma questão a ser resolvida ou um conjunto de direitos a serem efetivados, a partir de um diagnóstico do problema;

2) A formulação de um plano de ação para o enfrentamento do problema;

3) A decisão e escolha das ações prioritárias;

4) A implementação (através de leis e procedimentos administrativos); e

5) A avaliação dos resultados alcançados.

Ao longo dessas fases, é necessário que haja um monitoramento e fiscalização por parte da própria sociedade civil, ou por órgãos do governo. Portanto, a população deve ter acesso a essas informações de forma acessível e transparente. Contudo, nem sempre uma política pública segue este ciclo, pois muitas vezes não é bem planejada e executada (como é o caso da política pública que norteia esta dissertação: a Lei 11.161/2005), ou não chega a ser implementada.

Convém, por fim, também elucidar o conceito de "Política Social", uma vez que no âmbito das Ciências Sociais, esta é considerada uma modalidade de política pública.

As políticas sociais são ações governamentais que, desenvolvidas através de programas, garantem direitos e condições dignas de vida ao cidadão, objetivando solucionar problemas sociais.

As políticas sociais também buscam a diminuição das desigualdades econômicas (HÖFLING, 2001, p. 31), visto que assumem um caráter assistencialista por exercerem impacto sobre o bem-estar dos cidadãos, geralmente no que diz respeito à alimentação; saúde, habitação, previdência, transporte de massa e saneamento, etc. (AUGUSTO, 1989). 


\subsubsection{Política Pública Educacional}

As políticas públicas educacionais são as ações do Estado referentes à Educação escolar, ou seja, às questões escolares. É importante acrescentar o termo "escolar" a esta nomenclatura, pois, como observa Adão Oliveira (2010, p. 5-6), a educação é algo que transcende o ambiente escolar, constituindo-se em

Tudo o que se aprende socialmente - na família, na igreja, na escola, no trabalho, na rua, no teatro, etc. -, resultado do ensino, da observação, da repetição, reprodução, inculcação, é educação. Porém, a educação só é escolar quando ela for passível de delimitação por um sistema que é fruto de políticas públicas.

Para o autor, é imprescindível a existência de um ambiente próprio do "fazer educacional". Neste caso, a escola se configura em um ambiente de ensino-aprendizagem, a qual deve abarcar o papel de comunidade que articula inúmeros sujeitos tais como os alunos e seus pais, a vizinhança, os professores, os servidores e o próprio Estado, articulador das ações que a afetarão positiva ou negativamente.

No mesmo pensamento, Fábio Souza (2009, p. 22, grifo meu) define as políticas educacionais como "construções discursivas que tentam fixar o sentido outorgado à educação em dado momento". Esta definição coincide com meu pensamento de que todo discurso é político, como afirma Severo (2013, p. 458), ao dizer que “[...] todo discurso é político, na medida em que produz efeitos variados sobre a realidade, os sujeitos, as relações, os comportamentos, as línguas, entre outros".

Celani (2008, p. 18), ao discorrer sobre a implementação de políticas educacionais afirma que "o estabelecimento de uma política educacional sólida é particularmente difícil, pois as políticas educacionais são geralmente afetadas por políticas econômicas e sociais, que nem sempre caminham na direção que seria a ideal para a educação".

\subsubsection{Política Linguística}

Apesar de o termo "Política Linguística" ${ }^{19 "}$ ser recente no Brasil (OLIVEIRA, G., 2007), percebe-se de forma clara o crescente interesse por esse campo de investigação por meios de publicações, pesquisas, bem como o aumento de estudos nessa área.

\footnotetext{
${ }^{19}$ Muitos autores, ao invés de utilizarem a nomenclatura "Política Linguística", optam por utilizar a expressão "Política de Língua".
} 
O ENPLE (Encontro Nacional sobre Políticas de Língua(s) e Ensino) é considerado um importante evento na área de LA no Brasil. Sua terceira edição, realizada em Brasília no ano de 2009, teve como tema "Avaliando Políticas Linguísticas para um mundo plural”, no qual foram fomentadas reflexões sobre políticas linguísticas.

De 2009 até hoje já foram realizadas três edições do evento e de maneira semelhante, em 2013 o $10^{\circ}$ Congresso Brasileiro de Linguística Aplicada (doravante CBLA) realizado no Rio de Janeiro, teve como temática "Política e políticas linguísticas".

Ao comentar sobre este tema escolhido para o $10^{\circ}$ CBLA, Leffa $(2013$, p. 11) afirma que “o tema 'Política e políticas linguísticas', não poderia ser mais adequado, dado o atual cenário político brasileiro e as discussões sobre novas políticas públicas educacionais”.

Para Gimenez (2013), a decisão de refletir acerca deste tema no $10^{\circ} \mathrm{CBLA}$ foi uma decisão "altamente auspiciosa'. Já para Rojo (2013), tal tema foi "muito bem-vindo", pois tratava-se de discutir sobre como os linguistas tem se posicionado quanto às privações que tem sofrido, ou seja, tratava-se de discutir política.

Neste pensamento, Rajagopalan (2008), ao resenhar a obra "As políticas linguísticas" de Louis-Jean Calvet (2007), afirma que abordar Política linguística significa estar à frente das tendências mundiais.

Conforme exposto pela opinião dos linguistas aplicados supramencionados, é possível verificar a ascendência de tal temática, sua visibilidade e importância no campo da LA contemporânea. Entretanto, ainda me parece ser necessário questionar em que realmente consiste uma Política linguística?

Segundo Rajagopalan (2013), ainda há certa confusão e indefinição no tocante ao conceito de "Política linguística", visto que tal termo está sujeito a muitas interpretações. Tal multiplicidade de interpretações, segundo o autor, pode gerar deslizes de argumentos e equívocos. De acordo com este pensamento, Severo (2009, p. 453), afirma que "o conceito de política linguística é complexo e polissêmico".

Acerca deste assunto, Calvet (2007), traz à tona dois conceitos cruciais a toda comunidade linguística como política e planejamento/planificação linguística. O primeiro termo se refere às decisões do Estado relativas às línguas, ao passo que o segundo se configura como a implementação dessas decisões. Sendo assim, para intervir em situações linguísticas, o Estado utiliza-se da lei, visto que ela "é um dos principais instrumentos do planejamento linguístico" (CALVET, 2007, p. 76). Essas leis linguísticas têm seus efeitos e, de acordo com Francisco (2009, p. 306), se distinguem: 
1) Pelo modo de intervenção (incitativo ou imperativo);

2) Pelo conteúdo a sofrer intervenção (a forma, o uso, ou a defesa das línguas),

3) Pelo campo de aplicação geográfica (internacional, nacional, regional),

4) Pelo nível de intervenção jurídica (podem ser definidas pela Constituição, por leis, decretos, resoluções, etc).

Historicamente, enquanto disciplina, a Política linguística nasceu na segunda metade do século XX, e está associada a "mudanças políticas que levaram a alterações no estatuto das diversas comunidades linguísticas" (OLIVEIRA, G., 2007, p. 7). Logo, infere-se que a política linguística objetiva intervir de forma proposital nos rumos de uma língua, e está associada a situações concretas que demandam decisões políticas. Portanto, é cabível afirmar que política linguística se refere "às mais diversas atividades de cunho político que envolvem, ou melhor, giram em torno da linguagem" (RAJAGOPALAN, 2013, p. 30, grifo meu).

O mesmo autor chama atenção ao fato de que a política linguística frequentemente é confundida com a política $d a$ Linguística. Porém, afirma que política linguística, apesar de ser uma decorrência natural dos avanços da Linguística teórica, "pouco ou nada tem a ver com a Linguística” (IBIDEM, p.20), e sim com as línguas e com a política. A Linguística, por exemplo, sempre alardeou sua neutralidade política, enquanto a Política linguística assume seu caráter essencialmente político. Enquanto a Linguística frisa o caráter descritivo de suas investigações, a Política linguística é prescritiva e interventora. Logo, entre a política linguística e a Linguística existem diferenças claras, evidenciando-se a incompatibilidade entre elas. Contudo, é possível verificar que em determinados casos, os interesses da Política linguística se fundem com os interesses da Linguística.

\title{
2.2.3.1 Em que medida o homem pode intervir na língua ou nas línguas?
}

Calvet (2007, p. 11) afirma que

\begin{abstract}
A intervenção humana na língua ou nas situações linguísticas não é novidade: sempre houve indivíduos tentando legislar, ditar o uso correto ou intervir na forma da língua. De igual modo, o poder político sempre privilegiou essa ou aquela língua, escolhendo governar o Estado numa língua ou impor à maioria a língua de uma minoria.
\end{abstract}

No Brasil, o mito da unidade linguística evocou os primeiros atos de política linguística no território nacional que determinaram a ilusão de um "país monolíngue". A 
imposição do Português como língua de uso geral, praticamente implantado "à força" no século XVIII, esboçou uma "política linguística com vistas à perspectiva de 'construção do monolinguismo" (DALINGHAUS, 2009, p.3), uma política linguística autoritária, contribuindo para o que Rajagopalan (2013) chamou de "modo top dow", no qual as políticas linguísticas são implantadas de cima para baixo.

Entretanto, como elucidou Leffa (2013, p. 8), “é uma ilusão legislar sobre a língua e proibir o seu uso". Logo, o que se percebe com o passar do tempo é o fato de que ainda que somente o Estado tenha o poder e os meios para oficializar escolhas políticas, qualquer grupo pode elaborar uma política linguística. Contrariamente ao que antes se pensava, as políticas linguísticas não emanam somente de cima para baixo, mas têm eclodido de diversos segmentos da sociedade. Todo cidadão, no tocante às políticas públicas, tem direito a voz, e tais vozes devem ser ouvidas, porém não somente ouvidas: políticas e práticas devem ser implementadas com o intuito de "garantir" essas vozes (IBIDEM, p. 14).

Não obstante, é válido ter em mente que a língua prossegue a evoluir e a seguir seu curso natural, ainda que homens tentem sobre ela legislar. Um bom exemplo é o próprio Brasil, tendo em vista que à época de sua colonização "deveria” configurar-se como um país "monolíngue", visto que o Português deixou de ser LE e passou a ser língua oficial, atribuindo a "hegemonia" à língua que hoje, grande parte dos brasileiros denomina sua LM. Contudo, atualmente no território nacional se falam mais de 222 línguas. Trata-se da existência "de pelo menos 222 idiomas falados, como línguas maternas, por cidadãos brasileiros natos!"' (MAHER, 2013, p. 117).

\subsubsection{Maneiras de o linguista aplicado fazer Política linguística}

Rojo (2013) relembra que Rajagopalan (2004) discutiu três maneiras de o linguista aplicado tomar participação nas políticas públicas e fazer política linguística, paralelamente às suas pesquisas acadêmicas e aos seus resultados:

1) Fazendo lobby ou "conchavos" em momentos decisórios, manifestando-se contra ou a favor de determinado ato político,

2) Como representante de um corpo social, em Associações de corpo e Agências de fomento, 
3) Planejando e executando políticas públicas, participando como consultor, assessor, ou membro em secretarias, ministérios, etc.

Rojo (2013) acrescenta que recentemente há uma quarta forma de o linguista aplicado participar nas políticas sociais: planejando e executando políticas públicas, pesquisando seus efeitos e resultados para corrigir rumos de ação política. Para a autora, "somente essa última efetivamente agregaria pesquisa e participação nas políticas públicas, mas é bastante rara em LA" (IBIDEM, p. 69).

Refletindo sobre essas quatro formas de o linguista fazer política linguística, vejo que a presente pesquisa se encaixa na quarta maneira, uma vez que propõe uma reavaliação e mudanças possíveis nos rumos da Lei 11.161/2005, refletindo sobre suas particularidades, descompassos e necessidades evocadas por aqueles que são diretamente afetados por ela, ou seja, a comunidade escolar, pois como argumenta Leffa (2013, p.16), a comunidade acadêmica é um "importante ator no processo de realização de políticas enquanto textos e enquanto práticas" e deve envolver-se ativamente sem dar espaço à passividade ou à acomodação de deixar as questões políticas para outros. Como bem elucidaram Nicolaides e Tílio (2013, p. 287-288, grifo meu), é crucial

\footnotetext{
[...] lembrarmos o quanto é importante fazermos política, e que é também papel do linguista aplicado preocupar-se com essas questões. Ainda nesse sentido, e tão igualmente importante, é o fato de que, se defendemos uma Linguística Aplicada Crítica, que preconiza a compreensão de contextos discursivos que levem ao alívio do sofrimento humano (PENNYCOOK, 2001; 2004; 2006), parece que há aí, no mínimo, uma incoerência de nossa parte. Portanto, advogamos que é papel do linguista aplicado, sim, interferir, opinar e agir diretamente em políticas linguísticas, desde as que dizem respeito a políticas linguísticas para a preservação e/ou reconhecimento de línguas minoritárias (como as de indígenas, imigrantes, LIBRAS etc.), até em políticas de ensino de línguas.
}

Portanto, levando em consideração as definições apresentadas de política pública, política educacional e política linguística, compreendo que a Lei 11.161/2005, com toda sua particularidade, é incluída nesses três tipos de política.

Trata-se de uma política pública por ser uma ação interventiva do governo, que, efetivando seus propósitos em programas e ações, verá resultados e mudanças na sociedade. Configura-se também como uma política educacional, visto que, ainda que sua implementação tenha repercutido fortemente na politica externa do país, seu maior local de incidência é o ambiente escolar, pois se trata de uma política referente ao processo de ensino- 
aprendizagem, neste caso, de uma LE. Os maiores afetados - bem como interessados - são os sujeitos participantes da comunidade escolar como um todo (alunos, pais, professores, etc). Por fim, tal lei também abarca o status de política linguística, pois diz respeito a uma questão pontual de língua/linguagem: o ensino de Espanhol em solo brasileiro.

Conforme tais definições e reflexão de suas implicações, é possível demonstrar a posição da Lei 11.161/2005 na figura seguinte:

Figura 1 - A Lei 11.161/2005 como política pública, política educacional e política linguística

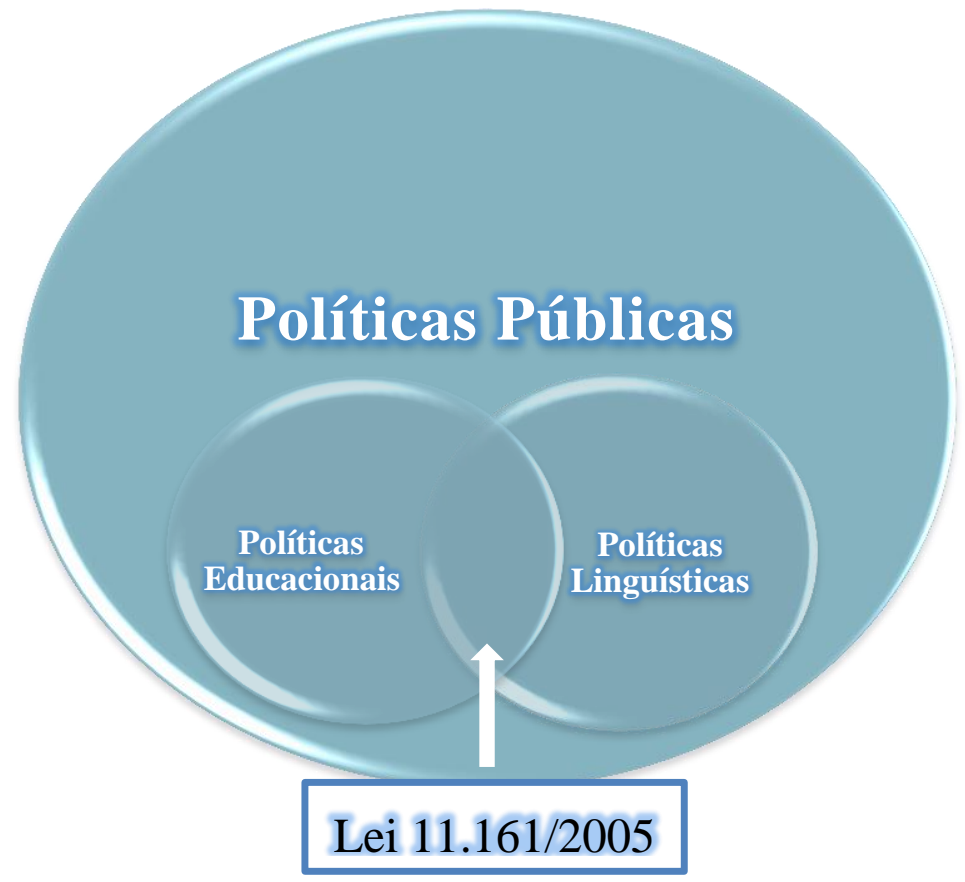

Fonte: Autoria própria

De acordo com a imagem acima, as políticas públicas incluem, em nível de igualdade, as políticas educacionais e as políticas linguísticas. A Lei 11.161/2005 resulta, pois, na fusão entre essas três políticas, e, por abarcar o status educacional e linguístico, como destaca Ribeiro da Silva (2011, p. 54), pode também configurar-se como uma política linguística educacional, visto que esta se caracteriza como aquela que "diz respeito às decisões políticas que, direta ou indiretamente, envolvem e afetam questões linguísticas”.

Para melhor situar a Lei 11.161/2005, sua implantação em solo brasileiro e suas implicações, como afirmou Fábio Souza (2009) ao citar Orlandi (1988), quando buscamos compreender determinada política linguística, “devemos não só procurar esclarecer fatos que se situam no escopo da política da linguagem, como tornar conhecidos percursos históricos que instituem uma política específica” (SOUZA, F., 2009, p. 25, grifo meu). 
Estou de acordo com Fabricio (2006, p. 60, grifo meu), quando afirma que no campo da LA é necessário "historicizar o objeto, compreendendo como foi produzido, dentro de qual regime de verdade, respondendo a quais conjunturas históricas e socioculturais e com quais pressupostos", entendo que a trajetória histórica, a legislação e os atos políticos referentes ao ensino de Espanhol no Brasil ao longo dos anos fazem-se necessários para a compreensão da realidade que hoje vivenciamos, pois, na história das disciplinas escolares, o lugar de uma disciplina dependeu de vários fatores condizentes à política educacional do pais, e ao contexto social e político no qual se inseria (AMARAL e ALMEIDA, 2010).

Dessa maneira, a seguir darei um panorama histórico ${ }^{20}$ relativo a alguns episódios que envolveram o ensino de Espanhol no Brasil e consequentemente, nos trouxeram até os dias de hoje, tendo esta longa trajetória de tentativas, idas e vindas, resultado finalmente, na implementação do Espanhol aos currículos plenos da Educação básica no ano de 2005, demonstrando que "determinantes históricos, sociais, econômicos e culturais contribuem para como se dá o desenvolvimento da educação e principalmente as reformas que ocorrem no sistema de ensino" (MACIEL e OLIVEIRA, 2011, p. 5, grifo meu).

\subsection{A PRESENÇA DO ESPANHOL NO SISTEMA EDUCACIONAL BRASILEIRO: UMA RETROSPECTIVA HISTÓRICA ${ }^{21}$}

"[...] a língua estrangeira ensinada pelo professor é construída historicamente através de lutas sociais, econômicas e políticas." (LEFFA, 2005, p. 112)

A presença do Espanhol no sistema educacional brasileiro não se inaugura com a aprovação da Lei 11.161 no ano de 2005 . Tal presença surge pela primeira vez no período imperial, há aproximadamente um século.

Conforme Guimarães (2011, 2012), a institucionalização das línguas vivas no Brasil no século XIX surgiu da necessidade de preparação do alunado para ingressar em cursos superiores, nos quais muitos professores utilizavam compêndios escritos em língua inglesa ou francesa, juntamente com o fato de que tais línguas eram matéria obrigatória ou recomendada

\footnotetext{
${ }^{20}$ É importante ressaltar que o objetivo não é fazer uma descrição exaustiva, porém propiciar uma melhor compreensão de alguns dos passos dados pelo ensino de Espanhol no Brasil, passos esses que julguei significativos, bem como os interesses políticos por trás de cada inclusão ou exclusão desta língua, de maneira que cheguemos finalmente, à obrigatoriedade do ensino da língua espanhola em 2005.

${ }^{21}$. Cabe destacar que neste trabalho não considerei a atuação jesuítica na alfabetização em Português e Espanhol durante os séculos XVI e XVII.
} 
para o ingresso no ensino superior de grandes universidades, como a Universidade de Coimbra. Outra motivação para o ensino de LEs se justificava em uma "finalidade utilitária", pois o país tinha acabado de abrir seus portos ao comércio estrangeiro, sobretudo o inglês.

Ainda segundo Guimarães (2012), no início do século XIX a educação brasileira sofreu grandes transformações. A ela era atribuída ampla importância em função dos interesses das oligarquias, que, no poder desde a proclamação da República, promoveram uma imigração em massa para o trabalho rural. Logo, a escolarização desses imigrantes servia como "adaptação ao trabalho requerido pelas elites" (IBIDEM, p. 4).

Nessa época, outros atores como a igreja, os governantes e as elites também disputavam seus espaços, pois reconheceram no ambiente escolar uma forma de moldar o povo de acordo com seus interesses. Portanto, é possível perceber que desde os tempos mais remotos, na educação brasileira a escolha do ensino de uma LE sempre esteve ligada a fatores econômicos, culturais e políticos ${ }^{22}$.

Com base nisso, identifiquei alguns episódios políticos que, através de legislações específicas, marcaram o ensino de Espanhol no Brasil. Tais episódios serão elucidados a seguir.

\subsubsection{Colégio Pedro II}

Fundado em 2 de dezembro de 1837, com caráter oficial determinado no Decreto Regencial de 20 de dezembro do mesmo ano, o Colégio Pedro II $^{23}$ configurou-se na instituição de ensino com maior expressão no panorama educativo do período imperial, e nas primeiras quatro décadas da República.

Tratava-se de uma instituição modelo, considerada a escola padrão do Brasil, seguida por outras escolas secundárias em todo o país no que tangia ao material utilizado e programas de ensino. O Colégio Pedro II era tão notável referência no âmbito educacional que, através do Decreto 11.530 de 18 de março de 1915, os certificados de conclusão de estudos de outras instituições somente teriam validade (inclusive para os alunos ingressarem no nível superior) caso tais instituições fossem equiparados ao Colégio Pedro II e inspecionados pelo Conselho Superior de Ensino (GUIMARÃES, 2012).

\footnotetext{
${ }^{22}$ Essa percepção já se torna visível na colonização do território brasileiro pelos portugueses, na qual houve a grande preocupação em realizar um trabalho educativo a fim de facilitar o processo de dominação e expandir a religião cristã (SALVADOR e SANTOS, 2012).

${ }^{23}$ Esta nomenclatura foi uma homenagem ao príncipe Regente, que, à época, contava com 12 anos de idade (RODRIGUES, 2010a).
} 
O Regulamento $\mathrm{n}^{\circ} 8$ de 31 de janeiro de 1838, que "Contém os estatutos para o Collegio de Pedro Segundo" ${ }^{24}$, em seus 239 artigos determina as orientações para o funcionamento da instituição. No Art. 117 (Do objecto de ensino), são especificadas as disciplinas estudadas, bem como suas respectivas cargas horárias.

As línguas especificadas são: Latim (aparecendo de forma privilegiada em duas disciplinas: Gramática Latina e Latinidade), Grego, Francês e Inglês, além de duas disciplinas também referentes ao ensino de língua: Grammatica Nacional e Rethorica e poética $^{25}$, como é possível ver nas tabelas a seguir ${ }^{26}$ :

Tabela 1- As disciplinas referentes a línguas ensinadas no Colégio Dom Pedro II (I)

\begin{tabular}{|c|c|c|}
\hline Ano & Disciplina & $\begin{array}{c}\text { Carga horária } \\
\text { semanal (lições) }\end{array}$ \\
\hline $\begin{array}{l}7^{\circ} \text { e } 8^{\circ} \text { anos: } \\
\text { (24 lições por semana) }\end{array}$ & $\begin{array}{l}\text { Grammatica Nacional } \\
\text { Gramática Latina }\end{array}$ & $\begin{array}{l}5 \\
5\end{array}$ \\
\hline $\begin{array}{l}6^{\circ} \text { ano: } \\
(24 \text { lições por semana) }\end{array}$ & $\begin{array}{l}\text { Latinidade } \\
\text { Língua Grega } \\
\text { Língua Francesa }\end{array}$ & $\begin{array}{l}10 \\
3 \\
1\end{array}$ \\
\hline $\begin{array}{l}4^{\circ} \text { e } 5^{\circ} \text { anos: } \\
\text { (25 lições por semana) }\end{array}$ & $\begin{array}{l}\text { Latinidade } \\
\text { Língua Grega } \\
\text { Língua Francesa } \\
\text { Língua Ingleza }\end{array}$ & $\begin{array}{l}10 \\
5 \\
2 \\
2\end{array}$ \\
\hline
\end{tabular}

Fonte: Autoria própria

\footnotetext{
${ }^{24}$ Como afirma Rodrigues (2010a), este documento é considerado a primeira normativa sobre o ensino regular do Brasil como Estado independente, no tocante ao ensino de línguas.

${ }^{25}$ Não se explicita no documento a que língua se referem os conteúdos de Grammatica Nacional e Rhetorica Poetica. Logo, pode-se concluir que a língua do Brasil, considerada a língua "nacional", era a língua portuguesa.

${ }^{26}$ Como o objetivo neste momento é analisar as línguas, não coloquei nas tabelas apresentadas as demais disciplinas. $\mathrm{O}$ currículo completo pode ser visto em: <http://www.histedbr.fae.unicamp.br/navegando/fontes escritas/3 Imperio/regulamento\%20n.\%208\%201838\%20\%20estatutos\%20para\%20o\%20col\%20pedro\%20ii.pdf $>$. Acesso em 05 jul. 2014.
} 
Tabela 2 - As disciplinas referentes a línguas ensinadas no Colégio Dom Pedro II (II)

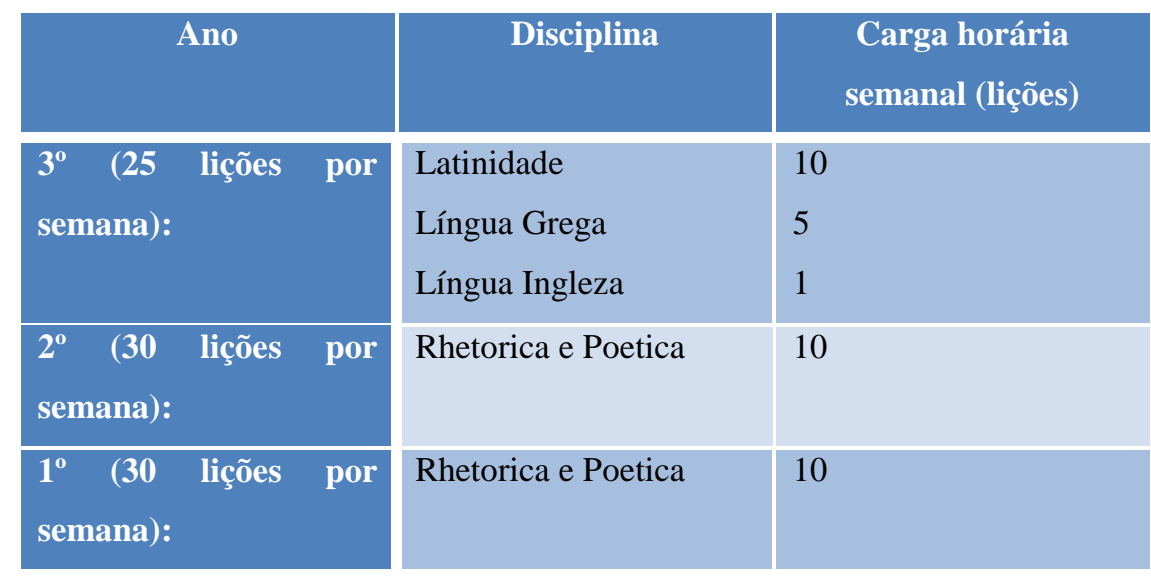

Fonte: Autoria própria

Conforme os dois quadros acima, onde apresento os grupos de séries ou anos escolares (denominados "aulas" no Art. 49), através da comparação de cargas horárias fica evidente que já no período imperial, a língua nacional e seu estudo se sobressaía em relação às línguas estrangeiras, visto que as disciplinas Gramatica Nacional e Rhetorica poética desfrutam de maior carga horária nos blocos apresentados. Apenas Gramática Latina e Latinidade possuíam uma carga horária mais próxima da carga horária destinada às disciplinas referentes ao Português. Tal constatação coincide com o pensamento de que foi durante o Império que as línguas estrangeiras ${ }^{27}$ passaram a ser "claramente consideradas a língua do outro, visto que o português se estabelecera como a língua nacional e, portanto, como referência para a alteridade" (SOUZA, S. 2005, p. 105). Assim, no período imperial já é possível ver a existência da política linguística que visava a hegemonia da língua portuguesa. Posteriormente, em 1854, o Alemão e o Italiano foram introduzidos ao currículo do Dom Pedro II, "passando a ser o inglês; o francês e o alemão, matérias obrigatórias, enquanto que o italiano era voluntário" (LASECA, 2008, p. 51).

Logo, no ano de 1919, o Espanhol foi incluído pela primeira vez no sistema educativo brasileiro (somente como disciplina optativa), através da abertura de concurso público para a cadeira de Espanhol no Colégio Pedro II, aprovada pela Lei 3.674, de 7 de janeiro de 1919. Como elucidou Guimarães (2011, p. 2), "a cadeira de espanhol foi criada em reciprocidade ao

\footnotetext{
${ }^{27}$ É válido ressaltar que a língua inglesa e a língua francesa entraram no ensino público no início do século XIX, no ano de 1809, tendo em vista a ação dos protestantes missionários norte-americanos que vieram para o Brasil, bem como as mudanças que o país atravessava em função de ideias provenientes da Europa (da França, principalmente). Tudo isso possibilitou que o Brasil também se aproximasse das políticas culturais dos países hispano-americanos no final do século XIX e início do século XX.
} 
ato do governo do Uruguai que criou uma cadeira de português" ${ }^{\text {28 }}$. O primeiro professor a assumir foi Antenor Nascentes, que em 1920 publicou a Gramática de língua espanhola para uso de brasileiros, primeira gramática de Espanhol publicada no Brasil, considerada uma das primeiras obras de referência no ensino de Espanhol no território nacional. Tal obra apresentava uma ênfase gramatical nas semelhanças e diferenças entre esta língua e o Português. Posteriormente, na década de 40 foi publicado o Manual de Español, de Idel Becker. Nas duas obras há textos literários, gramática e exercícios estruturais. Contudo, como afirmou Camargo (2004, p. 140, grifo meu) acerca dessas duas obras,

[...] esses estudos, apesar de pioneiros, ajudaram a impor e a legitimar uma crença ingênua, sobretudo entre estudantes e muitos professores brasileiros de espanhol como LE, de que estudar essa língua é fácil e limita-se ao conhecimento das regras gramaticais e ao estudo comparativo do léxico por meio de semelhanças, diferenças e falsos cognatos.

Assim, neste período começou a ser consolidado o pensamento que até hoje permeia o imaginário de muitos brasileiros: Espanhol é fácil. Este pensamento contribuiu para o desinteresse do brasileiro em aprender a língua de maneira formal ${ }^{29}$, como demonstrou Laseca (2008, p. 24, grifo meu), ao dizer que o Espanhol

[...] foi até uma época relativamente recente um idioma quase ignorado no Brasil. Como exemplo, o livro publicado pelo Grêmio Espanhol de Socorros Mútuos e Instrução, de Belo Horizonte, em comemoração dos seus noventa anos, narra a história de quando a instituição decidiu organizar um curso de espanhol na década dos 50, curso gratuito para os espanhóis e acessível para os brasileiros. Contrataram um professor, conseguiram materiais e abriram a matrícula. Não apareceu ninguém.

Portanto, nota-se que a visão da língua espanhola no imaginário brasileiro vai se construindo a partir da inclusão do Espanhol na grade curricular do Colégio Dom Pedro II em 1920, bem como com o auxílio de obras que foram lançadas com o decorrer dos anos, juntamente com as transformações políticas e econômicas pelas quais o Brasil passava. Todos

\footnotetext{
${ }^{28}$ Logo, já no período imperial existiam "políticas de reciprocidade" no tocante ao ensino de línguas. A própria Lei 11.161/2005 gerou uma política de reciprocidade do governo argentino, que, em resposta à implantação do Espanhol no ensino brasileiro, aprovou a Lei 26.468 de 17 de dezembro de 2008, que estabelece a obrigatoriedade de oferta do Português na escola secundária de todo país e também na escola primária das províncias na fronteira brasileira. A Argentina tem até 2016 para consolidar tal implementação.

${ }^{29}$ Este pensamento perdurou durante muitos anos, porém mudou radicalmente no início da década de 90 , quando o Espanhol começou a ascender em solo brasileiro, como será evidenciado ainda neste capítulo, nos antecedentes da Lei 11.161/2005.
} 
esses fatores colaboraram para o que Celada (2002, p. 102) chamou de "ilusão da competência espontânea", que se resume na metonímia: "espanhol - língua parecida - língua fácil - língua espontânea $=$ portunhol $^{30 "}$.

\subsubsection{A Lei Rocha Vaz}

A década de 20 enfrentou muitas mudanças políticas e educacionais no Brasil, em função do crescimento industrial, o aumento da população, o desenvolvimento urbano, entre outros. Todos esses fatores acarretaram transformações na chamada República Velha. Eclodiu, dessa maneira, a reforma nomeada como "Lei Rocha Vaz", que, mediante o decreto 16.782-A de 13 de janeiro de 1925, dispôs em seis anos o ensino secundário, tendo o Espanhol e o Italiano aparecido como matéria facultativa. A cadeira de Espanhol foi extinta e o professor realocado para uma cadeira de Português. Assim, “[...] o ensino de Espanhol não durou muito tempo nesta primeira fase" (GUIMARÃES, 2011, p. 3).

Posteriormente, através do Decreto Federal n 18.564 de 15 de janeiro de 1929, os programas de ensino do Colégio Pedro II traziam o ensino de literatura espanhola. Segundo Guimarães (2011), percebe-se nesse momento a quebra do vínculo entre a literatura e o ensino da língua, visto que a literatura passaria a ser ensinada independentemente do ensino da língua. Entretanto, a disciplina literatura abrangia as literaturas "orientais, grega, latina, italiana, francesa, provençal, espanhola, portuguesa, inglesa, alemã e brasileira" (IBIDEM, grifo meu). Logo, a literatura espanhola era apenas mais uma literatura dentre as muitas especificadas, e o Espanhol prosseguiu como língua optativa.

\subsubsection{A Reforma Francisco Campos}

Após a revolução que levou Getúlio Vargas ao poder, em 1930, foi criado o Ministério da Educação e Saúde Pública. O Brasil inicia uma "campanha de nacionalização da educação" (LASECA, 2008, p. 52), conhecida como Reforma Francisco de Campos, então ministro da Educação. Tal reforma afetou significativamente o ensino de LEs no Brasil, que neste momento, foi tomado de extremo nacionalismo: escolas criadas por imigrantes foram

\footnotetext{
30 "Portunhol" geralmente refere-se à interlíngua criada pelo falante de Português ao tentar falar Espanhol (ou vice-versa). Atualmente há conhecidas interl ínguas tais como o "Espanholês", o "Franglais" e o "Spanglish". Para Celada (2002), tal termo diz respeito à língua do falante iludido pela competência espontânea, tendo em vista que este possui a crença de que Espanhol é "muito fácil".
} 
fechadas (ou convertidas em escolas públicas), e houve grande repressão em relação ao ensino bilíngue juntamente com a destruição de material didático e prisão de professores (IBIDEM).

O ensino secundário foi modificado a partir do Decreto 19.890 de 18 de abril de 1931, que "dispõe sobre a organização do ensino secundário". Inúmeras medidas e alterações foram feitas, entretanto, cabe destacar as que afetaram diretamente a língua à qual se dedica este estudo. Se extinguiram os cargos de livres docentes do Colégio Pedro II, formando-se o corpo docente de professores catedráticos e auxiliares de ensino (GUIMARÃES, 2011, p. 3).

Dessa maneira, o ensino de Espanhol foi relegado, continuando somente o ensino de sua literatura, sem nenhuma mudança significativa. Sobre isso, Guimarães (IBIDEM) discorre que “[...] há uma mudança na concepção política em relação à integração com os demais países sul-americanos, uma vez que na formação do alunado o conhecimento da cultura desses países não se dá através do aprendizado de sua língua, mas sim de sua literatura”.

\subsubsection{A Reforma de Capanema e a Lei Orgânica do ensino secundário de 1942}

Visando reestruturar a educação nacional, no ano de 1942, por meio do Decreto-lei 4.244 de 9 de abril, Gustavo Capanema instituiu a "Lei orgânica do Ensino secundário" (doravante LO/1942).

Este decreto é o primeiro texto legal que determina a obrigatoriedade do ensino de Espanhol nas escolas secundárias do Brasil, e se inseriu em um movimento de reestruturação que ficou conhecido como "Reforma de Capanema".

A essa época a justificação para a inclusão do Espanhol na grade curricular se deu em função da língua ser de "antiga e vigorosa cultura e de grande riqueza bibliográfica" (CHAGAS, 1979, p. 116), visto que a Literatura em língua espanhola era reconhecida em função de seus consagrados autores.

A LO/1942 reestruturou os níveis escolares que passaram a ser divididos em: a) Primário - para crianças de 7 a 11 anos e b) Secundário - dos 12 aos 18 anos. O Secundário, por sua vez, dividia-se em dois ciclos: Ginasial (com duração de 4 anos) e Clássico ou Científico (com duração de 3 anos), podendo o aluno decidir entre o Curso clássico ou científico de acordo com suas preferências.

O foco neste momento recairá sobre o Secundário. Como é possível ver nos quadros seguintes, as línguas oferecidas em cada etapa de ensino foram: 
Quadro 1 - Nível secundário - As línguas ensinadas no Ginasial (LO/1942)

\begin{tabular}{|c|l|}
\hline SÉRIE & \multicolumn{1}{|c|}{ LÍNGUA } \\
\hline & $\begin{array}{l}\text { Português } \\
\text { Latim } \\
\text { Francês }\end{array}$ \\
\hline $\mathbf{1}^{\mathbf{0}}$ & $\begin{array}{l}\text { Português } \\
\text { Latim } \\
\text { Francês } \\
\text { Inglês }\end{array}$ \\
\hline $\mathbf{2}^{\mathbf{o}}$ & $\begin{array}{l}\text { Português } \\
\text { Latim } \\
\text { Francês } \\
\text { Inglês }\end{array}$ \\
\hline $\mathbf{3}^{\mathbf{0}} \mathbf{e} \mathbf{4}^{\mathbf{0}}$ & \\
\hline
\end{tabular}

Fonte: Autoria própria

Quadro 2 - Nível Secundário - As línguas oferecidas no Curso Clássico e no Curso Científico (LO/1942)

\begin{tabular}{|c|c|c|c|}
\hline \multicolumn{2}{|r|}{ CURSO CLÁSSICO } & \multicolumn{2}{|r|}{ CURSO CIENTÍFICO } \\
\hline SÉRIE & LÍNGUA & SÉRIE & LÍNGUA \\
\hline $1^{\circ}$ & $\begin{array}{l}\text { Português } \\
\text { Latim } \\
\text { Grego } \\
\text { Francês ou Inglês } \\
\text { ESPANHOL }\end{array}$ & $1^{o}$ & $\begin{array}{l}\text { Português } \\
\text { Francês } \\
\text { Inglês } \\
\text { ESPANHOL }\end{array}$ \\
\hline $2^{\circ}$ & $\begin{array}{l}\text { Português } \\
\text { Latim } \\
\text { Grego } \\
\text { Francês ou Inglês }\end{array}$ & $2^{\circ}$ & $\begin{array}{l}\text { Português } \\
\text { Francês } \\
\text { Inglês }\end{array}$ \\
\hline $3^{\circ}$ & $\begin{array}{l}\text { Português } \\
\text { Latim } \\
\text { Grego }\end{array}$ & $3^{\circ}$ & Português \\
\hline
\end{tabular}

Fonte: Autoria própria

Observando os dois quadros acima e analisando as cargas horárias de cada língua, temos como resultado a tabela apresentada a seguir: 
Tabela 3 - As cargas horárias das línguas estudadas (LO/1942)

\begin{tabular}{|c|c|c|c|}
\hline LINGUA & GINASIAL & CIENTÍFICO & CLÁSSICO \\
\hline Francês & 4 anos & 2 anos & 2 anos \\
\hline Inglês & 3 anos & 2 anos & 2 anos \\
\hline ESPANHOL & - & 1 ano & 1 ano \\
\hline Latim & 4 anos & 3 anos & 3 anos \\
\hline Grego & - & - & - \\
\hline
\end{tabular}

Fonte: Autoria própria

Observando a distribuição das LEs, algumas observações podem ser feitas. Primeiramente, esta foi uma época singular, na qual o ensino de LEs foi enfatizado, podendo configurar-se como uma "primeira tentativa de introduzir as línguas estrangeiras ${ }^{32}$ no currículo brasileiro, destinando um total de 35 horas ao ensino de idiomas (clássicos e modernos $^{33}$ ), o que representava $19 \%$ de todo o currículo" (LASECA, 2008, p. 54).

No que diz respeito à língua espanhola, nessa altura esta língua era “identificada como a língua de autores consagrados, como Cervantes, Bécquer e Lope de Vega e foi incorporando-se à maioria das escolas secundárias" (LEMOS, 2008, p. 27). Neste pensamento, Celada (2002, p. 33) observa que "[...] era aos grandes autores e não à língua que algum saber era atribuído". Foi neste momento que a obra de Idel Becker (Manual de español) consagrou uma forma de ensinar a língua, cabendo ao aluno "[...] aprender as regras prescritivas da língua e suas exceções, além de memorizar o vocabulário, as classes gramaticais e as conjunções verbais para que possa obter êxito na LE” (CAMARGO, 2004, p. 140). Sendo assim, nesse momento o ensino de Espanhol trazia a relação assimétrica entre professor-aluno, visto que o docente detinha todo o saber e poder em sala de aula.

Ainda a respeito do Espanhol, o espaço dedicado à língua na grade curricular é praticamente simbólico: apenas um ano de estudos no primeiro ano do clássico ou do científico. Comparando com as demais cargas horárias (como o Inglês e o Francês, por exemplo), Rodrigues (2010a) atribui esse tempo mínimo à visão do Espanhol como uma língua parecida e fácil por sua proximidade com o Português. Com base nas observações acima, apoiando-me em Celada (2002), quando diz que neste momento o Espanhol foi visto

\footnotetext{
${ }^{31}$ Vale lembrar que no Secundário o aluno optava pelo Curso Clássico ou Científico. Logo, a essa altura, em sua trajetória de estudos o aluno tinha apenas um ano de estudos da língua espanhola.

${ }^{32}$ Um fator que pode ser salientado é a ausência do Italiano e do Alemão. Tal ausência pode ser justificada em função da evolução da II Guerra Mundial.

${ }^{33}$ Clássicos: Latim e Grego. Modernos: Francês, Inglês e Espanhol.
} 


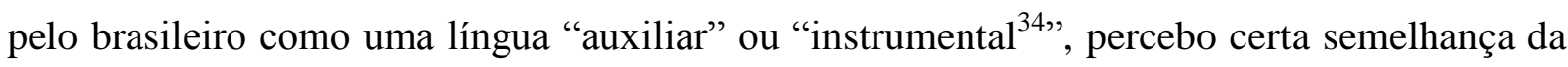
obrigatoriedade do Espanhol em 1942 com a obrigatoriedade do Espanhol em 2005: a língua implementada com uma carga horária pequena, praticamente simbólica quando comparada às demais línguas estudadas (hoje, o Português e na maioria dos casos, o Inglês).

Embora o ensino de LEs estivesse em um momento de valorização, a realidade é que nessa época, no Brasil e em todo o mundo, em função da forte dependência econômica e cultural dos Estados Unidos, começava o início do auge da língua inglesa, ocupando o espaço no qual, antes, o Francês reinava (LASECA, 2008, p. 55).

\subsubsection{O PL no 4.606/1958 de Juscelino Kubitscheck: Equiparando o Espanhol ao Inglês ${ }^{35}$}

Muitos projetos de lei (doravante PL's) foram propostos para incluir o Espanhol como disciplina obrigatória nos currículos da Educação básica brasileira. Nesta dissertação não abarcaremos a análise detalhada de cada um deles por tratar-se de um número considerável ${ }^{36}$.

A justificativa dada pela grande maioria desses PL's consistia em implantar o Espanhol em nome da integração econômica, social, política e cultural dos países da América Latina. Ainda que nenhum desses PL's tenha de fato, se convertido em leis ${ }^{37}$, demonstram que o interesse pelo Espanhol é antigo.

Convém ressaltar o primeiro projeto de lei (doravante PL) que buscou - não incluir o Espanhol, pois este, apoiado pela LO/1942, já fazia parte do currículo do ciclo secundário -, mas equiparar seu ensino ao ensino da língua inglesa: O PL nº 4606/1958 do Poder executivo, tendo como autor o então presidente da República, Juscelino Kubitscheck (doravante JK).

\footnotetext{
${ }^{34}$ A autora acrescenta que a obrigatoriedade do ensino de Espanhol neste momento não chegou a "ter um peso que marque e modifique a relação mais geral que o brasileiro teve com o espanhol durante o século passado". (IBIDEM, p. 32). Acredito que a autora faz tal afirmação tendo em vista o pouco e breve contato que o aluno teve com a língua naquele tempo.

${ }^{35}$ É válido discorrer sobre este acontecimento político, tendo em vista que esse PL está diretamente relacionado à LO/1942, tratada anteriormente. Também foi de meu interesse discorrer especificamente acerca do PL 4.606 de 1958 por nele enxergar muitas semelhanças com a implantação da língua espanhola no ano de 2005.

${ }^{36}$ Muitos trabalhos afirmam haver em média, "15 projetos de lei" sobre o ensino de Espanhol no Brasil. Entretanto, Tenório Mejia (1998), em sua dissertação "Política Linguística e Política de Espanhol no Brasil” fez um levantamento na Câmara Legislativa acerca dos projetos de lei vinculados ao ensino de línguas, e, em sua busca, dos PL's encontrados, dezenove eram referentes ao ensino de Espanhol. Rodrigues (2010a), em sua tese de doutorado intitulada "Língua viva, letra morta: Obrigatoriedade e ensino de espanhol no arquivo jurídico e legislativo brasileiro”, ao buscar os PL's referentes ao ensino de Espanhol na Câmara Legislativa também encontrou dezenove PL'S, e outros sete no portal do Senado Federal, totalizando 26 PL's relativos ao ensino de Espanhol em solo brasileiro, que datam desde 1958 até o ano de 2007.

${ }^{37}$ Os motivos para nenhum desses PL's ter se convertido em lei são variados, como problemas logísticos para a implantação; escassez de recursos humanos e didáticos, pressões de lobistas descontentes com a posição que o Espanhol poderia alcançar em detrimento de suas línguas, etc (LASECA, 2008).
} 
Este PL foi recebido na Câmara dos Deputados em 15 de outubro de 1958 e arquivado em 15 de abril de 1971, ano no qual foi aprovada a segunda LDB $^{38}$. Este PL foi proposto em um momento no qual o governo brasileiro inclinava-se para a América Latina, movimento que ficou conhecido como "Operação Pan-Americana", tendo surgido quando o vicepresidente americano Richard Nixon, ao visitar os países da América Latina em 1958, foi recebido com protestos em função da política de seu país em relação aos demais. Desse modo, JK contatou o presidente dos Estados Unidos, Dwight Eisenhower, e buscou um novo relacionamento entre os países das Américas, sob um programa de desenvolvimento econômico. A proposta foi conversada, porém não obteve êxito.

Com base nesse breve quadro histórico, algumas considerações podem ser feitas levando em conta os seguintes documentos ${ }^{39}$ :

1) A textualidade (conteúdo) do PL nº 4606/1958,

2) A exposição de motivos no 745 do Ministro da Educação e Cultura, Clóvis Salgado,

3) A Mensagem no 327-58 encaminhada à Câmara dos Deputados pelo presidente JK.

O PL 4.606 de 1958 alterava o Decreto-Lei no 4.244 de 1942 (LO/1942), no que se referia ao aprendizado de Espanhol nos dois ciclos do ensino secundário. É válido lembrar que neste momento, o Espanhol era estudado somente durante um ano no ciclo secundário (ou no clássico ou no cientifico, não sendo estudado no ginasial), ficando aquém das demais LEs como o Inglês e o Francês, que, durante os dois ciclos do secundário, contavam com cinco anos de estudos (como demonstrado anteriormente) ${ }^{40}$. Este PL conteve apenas dois artigos. Vejamos o Art. $1^{\circ}$, tal como aparece no documento (CÂMARA DOS DEPUTADOS, 1958c, grifo meu):

Art $1^{\circ} \mathrm{O}$ idioma Espanhol será ministrado nos dois ciclos do ensino secundário observadas as mesmas bases estabelecidas no Decreto-lei no 4.244 de 9 de abril de 1942 para o ensino do idioma inglês, inclusive no que tange às séries e cursos em que será lecionado.

\footnotetext{
${ }^{38}$ A primeira LDB (Lei $\mathrm{n}^{\circ} 4.024$, de 20 de Dezembro de 1961) e a segunda LDB (Lei No 5.692 - de 11 de agosto de 1971) ainda serão abordadas nesta sessão.

${ }^{39}$ Para maior compreensão do leitor: PL 4606/1958: (CÂMARA DOS DEPUTADOS, 1958c). Exposição de motivos $n^{\circ}$ 745: (CÂMARA DOS DEPUTADOS, 1958a). Mensagem $n^{\circ}$ 327-58: (CÂMARA DOS DEPUTADOS, 1958b). Esses documentos estão disponíveis no acervo da Câmara dos Deputados, em: <imagem.camara.gov.br/Imagem/d/pdf/DCD16OUT1958.pdf\#page=20>. Acesso em 25 de julho de 2014. Seu teor completo também pode ser visto nos anexos E, F e G desta dissertação, respectivamente.

${ }^{40}$ Ver tabela 3.
} 
Portanto, neste PL, JK propõe uma mudança radical no ensino de língua espanhola no Brasil: o Espanhol seria estudado nos dois ciclos do secundário, e possuiria, como o Inglês, 5 anos de estudos.

Contudo, fica evidente que, mais uma vez, o objetivo para a valorização do Espanhol como disciplina escolar não estava centrado no valor educacional ou na formação do cidadão brasileiro que possui direito pleno à cidadania (e num mundo globalizado e poliglota, isto significa também a aprendizagem de LEs). Tal medida configurava-se claramente como uma "jogada" política para o melhor relacionamento entre os países das Américas, pois neste momento o governo empenhava-se em uma revisão da Política Continental, com a "adoção de medidas no setor da educação" (CÂMARA DOS DEPUTADOS, 1958a) que dessem novos rumos ao Pan-americanismo. Uma dessas medidas, como diz a mensagem $\mathrm{n}^{\mathrm{o}}$ 327-58 do presidente JK, consistiria na equiparação do Espanhol com o Inglês, configurando tal equiparação como o "corolário dos novos rumos dados ao pan-americanismo, em consequência da política adotada pelo Governo, eis que se trata do idioma falado pela maioria dos povos americanos" (CÂMARA DOS DEPUTADOS, 1958b). Dessa forma, o Governo brasileiro buscava "mais íntima aproximação dos países deste hemisfério" (IBIDEM).

Neste episódio, tal proposição não apenas se configura em um ato puramente político, como evidencia que o governo reconhecia que a carga horária destinada ao ensino do Espanhol era ínfima, e que havia a necessidade de que alguma providencia em relação a tão pouca valorização do Espanhol fosse tomada, como é possível perceber na exposição de motivos n ${ }^{\circ} 745$ do Ministro da Educação e Cultura, Clóvis Salgado (CÂMARA DOS DEPUTADOS, 1958a, grifo meu), quando este declara que

\footnotetext{
A atual Lei Orgânica do Ensino Secundário já prevê, é verdade, o ensino do Espanhol, mas com a duração de, apenas, um ano, e como disciplina do segundo ciclo, salientando as instruções metodológicas baixadas para a execução do programa que, entre as finalidades do ensino de Espanhol, está a de "mostrar-lhe a origem românica como a do Português que tem a língua de Castela e da maioria dos países americanos, o que ajudará a compreender os sentimentos pan-americanos". $\mathrm{O}$ maior estreitamento dos povos do continente americano reclama, no entanto, um estudo mais intenso do idioma espanhol no curso secundário e a sua inclusão como disciplina obrigatória no primeiro ciclo, a fim de ser dada maior difusão ao ensino e tornar possível a plena consecução dos seus objetivos.
}

Assim, no fragmento acima, por meio de palavras e frases elencadas, percebe-se: 
1) $\mathrm{O}$ reducionismo no qual a língua espanhola se encontrava, ainda que fosse obrigatória ("é verdade");

2) O tempo de estudos totalmente insuficiente para um contato digno com a língua ("apenas") e não obstante, somente no segundo ciclo ("e como disciplina do segundo ciclo");

3) A contradição ao citar as finalidades de ensino atreladas ao pouco tempo dedicado à disciplina. Presume-se assim, o reconhecimento de que tais finalidades não estavam sendo alcançadas;

4) A demonstração do interesse político que visava o estreitamento dos povos no imaginário brasileiro (“ajudará a compreender os sentimentos pan-americanos”);

5) Não é o aluno, privado de um ensino de Espanhol mais aprofundado, que necessita de maior tempo de estudo da língua, é o "estreitamento dos povos" = interesse político: ("O maior estreitamento dos povos do continente americano reclama, no entanto, um estudo mais intenso do idioma espanhol").

A proposta do PL 4.606 de 1958 não foi aprovada no Congresso Nacional, tendo assim, o ensino da língua espanhola permanecido da forma como estava, com apenas um ano de estudos em somente um ciclo do secundário.

Além de JK, outros dois presidentes da República foram proponentes de PL's que diziam respeito ao ensino de Espanhol em solo brasileiro: Fernando Henrique Cardoso, nos anos de 1987 e 1991 (enquanto ainda era senador), e Itamar Franco, em 1993, como presidente da República.

\subsubsection{As LDBs de 1961 e $1971^{41}$}

De acordo com Rodrigues (2010a, p. 84) dentre os acontecimentos jurídicos referentes à legislação que envolve o ensino de LEs no Brasil, "a aprovação e a implantação das LDBs se constituem no fato que adquire maior relevância no arquivo jurídico da segunda metade do século XX”.

Essas leis tiveram como principal finalidade regulamentar a educação formal nas instituições de ensino brasileiras, públicas e privadas, seguindo os princípios da Constituição

\footnotetext{
${ }^{41}$ Não incluí aqui a LDB de 1996 (Lei n 9.394 de 1996) por julgar que esta se insere em outro momento político e social do Brasil, bem como para manter a sequência da retrospectiva histórica aqui delineada. Logo, a terceira LDB será elucidada posteriormente.
} 
Federal, democratizando as decisões referentes ao rumo da educação brasileira, que também norteou a elaboração da LDB de 1996 (IBIDEM, 2010).

\subsubsection{A LDB de 1961 e o desaparecimento das LEs da legislação educacional brasileira}

No dia 20 de dezembro de 1961 foi sancionada a Lei $\mathrm{n}^{\circ}$ 4.024, que fixaria as Diretrizes e Bases da Educação Nacional (doravante LDB/1961). Esta lei é considerada um marco no histórico do ensino de LEs no Brasil, pois, segundo Rodrigues (2010a, 2010b, 2012), produziu uma ruptura na memória discursiva que as línguas carregavam até esse momento. $\mathrm{O}$ fato é que se na LO/1942 as LEs obtiveram espaço de destaque no currículo, na LDB/1961 são praticamente apagadas, excluídas, pois no texto desta lei não há uma só referência ao ensino de línguas estrangeiras. Dessa forma, as línguas desaparecem completamente da legislação educacional brasileira.

Todavia, a LDB/1961 criou os Conselhos Estaduais de Educação (doravante CEE’s), e, segundo o Art. 35 desta lei, a estes órgãos caberia a organização da estrutura curricular, completando as disciplinas obrigatórias e especificando as que seriam incluídas como disciplinas optativas, levando em consideração as especificidades de cada região. Sendo assim, as LEs poderiam de certa forma, subsistir, tendo em vista que, ainda que não mencionadas na legislação, poderiam ser incluídas como obrigatórias ou optativas ${ }^{42}$ pelos CEE's, e foi o que de fato aconteceu, em função do decreto de 1942 ter estabelecido uma estrutura escolar para o oferecimento de diversas línguas estrangeiras.

O apagamento das LEs da legislação educacional brasileira neste momento é chamado por Rodrigues (2010a) de "processo de desoficialização" por parte das instâncias governamentais. Sobre isso, a mesma autora (Rodrigues, 2012, p. 24) afirma que

Este processo de "desoficialização" do ensino de línguas estrangeiras, iniciado pela LDB/1961, se materializa na textualidade legal por meio do silêncio, do apagamento de qualquer referência às línguas. Neste sentido, a LDB/1961 assume e materializa, portanto, uma posição sobre o caráter do ensino de línguas que irá se perpetuar nas legislações subsequentes e que ainda encontra eco em certas discursividades que circulam atualmente: coloca-se em funcionamento, a partir desse apagamento na materialidade legal, um imaginário a partir do qual os conteúdos de línguas estrangeiras não deveriam ser tratados como componente curricular, mas sim extracurricular, ou seja, poderiam (ou deveriam) ser oferecidos fora da grade

\footnotetext{
${ }^{42}$ A possibilidade de inclusão de línguas estrangeiras no currículo aparece na alínea b do Art. 40, no qual se afirmava a permissão "aos estabelecimentos de ensino escolher livremente até duas disciplinas optativas para integrarem o currículo de cada curso" (BRASIL, 1961).
} 
curricular do ensino regular, chegando até mesmo a passar por um processo de terceirização.

No que diz respeito ao Espanhol, a mudança foi significativa, pois já na LO/1942, tal língua aparecia de forma meramente simbólica com apenas um ano de estudos frente a línguas que eram estudadas por cinco, seis anos (Inglês e Francês, respectivamente). Com a LDB/1961 o Espanhol foi praticamente extinto da grade curricular, visto que o Francês permanecia vivo em função de sua marcante presença cultural, e o Inglês a essa altura já se consolidava como a língua comercial, sendo neste período generalizada como LE, atribuindo às demais línguas um papel meramente secundário (LASECA, 2008).

\subsubsection{A LDB de 1971}

Em 11 de agosto de 1971 foi sancionada a Lei ${ }^{\circ}$ 5.682, Lei de Diretrizes e Bases da Educação Nacional (doravante LDB/1971). Esta nova lei dividiu os níveis de ensino em $1^{\circ}$ grau (com oito anos de duração) e $2^{\circ}$ grau (com três anos de duração) ${ }^{43}$. Esta lei manteve uma estrutura curricular semelhante à da LDB/1961, pois também permitia a inclusão de disciplinas obrigatórias e optativas. As "línguas estrangeiras" voltam a ser mencionadas nas opções entre as disciplinas a serem incluídas pelos CEE's, como se vê no parágrafo 2 do Art. 8 (BRASIL, 1971, grifo meu): “Em qualquer grau poderão organizar-se classes que reúnam alunos de diferentes séries e de equivalentes níveis de adiantamento, para o ensino de línguas estrangeiras e outras disciplinas, áreas de estudo e atividades em que tal solução se aconselhe."

Através deste fragmento, o único referente ao ensino de LEs na LDB/1971, é cabível fazer algumas observações. Em primeiro lugar, vê-se que nessa legislação, em igualdade à LDB/1961, não há a especificação de quais línguas estrangeiras deveriam ser ensinadas, e nem a quantidade dessas línguas, diferentemente do que ocorreu até o Decreto de 1942, já que as línguas estrangeiras (clássicas e modernas) eram especificadas juntamente com as suas cargas horárias para cada nível de ensino.

Uma segunda observação a ser feita é o lugar que, neste momento, as LEs pareceram ocupar no sistema educacional. A indicação de que classes com alunos de diferentes séries e níveis equivalentes de adiantamento demonstra mais uma vez um caráter de disciplina

\footnotetext{
${ }^{43}$ No ano de 1996, através da Lei no 9.394 (Lei de Diretrizes e Bases da Educação Nacional) esses níveis de escolarização se converteram nos níveis que hoje denominamos Ensino Fundamental e Ensino Médio. A LDB de 1996 será abordada a seguir.
} 
“extracurricular", logo, não necessária na estrutura curricular dos estabelecimentos de ensino. Outro fator que contribui para este pensamento é o acréscimo de "outras disciplinas", áreas de estudo e atividades", indicando certa indeterminação no sentido de categorização das línguas estrangeiras, que, nesse artigo, são nomeadas como disciplinas, entretanto, em grau de igualdade com áreas de estudo e atividades.

Com base nas considerações feitas a respeito dessa lei, a LDB/1971, seguindo os rastros deixados no imaginário brasileiro pela LDB/1961, como afirmou Rodrigues (2010a, p. 97), colaborou com “a difusão de um imaginário que desvincula o ensino de línguas do espaço escolar e reforça seu caráter enquanto conteúdo extracurricular".

Laseca (2008, p. 56), ao citar Daher (2006, p.7) ilustra as consequências gerais das duas LDBs aqui analisadas até este momento (LDB/1961 e LDB/1971), ao falar que

\begin{abstract}
As consequências gerais das LDBs de 1961 e 1971 foram que nessa época muitos alunos brasileiros nunca estudaram uma língua estrangeira nem no primeiro, nem no segundo Grau. E no que diz respeito ao espanhol, supôs, transcorridos menos de vinte anos desde sua implantação (Reforma Capanema de 1942), sua saída quase total do espaço educativo, no qual permaneceram o inglês e/ou, em menor medida, o francês.
\end{abstract}

Desse modo, os alunos brasileiros que, neste período, já não gozavam do estudo de LEs como algo necessário para sua formação, também não puderam ser beneficiados com o ensino da língua espanhola, tendo em vista que àquela época qualquer língua permanecia à margem das consagradas língua inglesa e francesa.

\title{
2.3.7 A Resolução ${ }^{44}$ n $^{0} 58$ de 1976
}

Em 22 de dezembro de 1976 foi assinada pelo presidente do Conselho Federal de Educação (CFE), Padre José Vieira de Vasconcellos, a Resolução no 58, que modificou o ensino de LEs no Brasil, até então regido pela LDB/1971.

No documento (BRASIL, 1976, grifo meu) ficou determinado que

O estudo de Língua Estrangeira Moderna passa a fazer parte do núcleo comum, com obrigatoriedade para o ensino de $2^{\text {ao }}$ grau, recomendando-se a sua inclusão nos currículos de $1^{\circ}$ grau onde as condições o indiquem e permitam.

\footnotetext{
${ }^{44}$ Convém destacar que no âmbito Legislativo uma Resolução tem como objetivo regular, modificar ou alterar o conteúdo de determinada lei. No caso desta resolução, a alteração foi feita na LDB/1971.
} 
Portanto, o estudo de língua estrangeira moderna (doravante LEM) passou a elencar as disciplinas obrigatórias oferecidas no $2^{\circ}$ grau. Analisando a textualidade dessa resolução, vale a pena destacar o sintagma "língua estrangeira moderna" apresentado no singular, visto que até então, a legislação havia se referido às "línguas estrangeiras", no plural. Pode-se inferir que as línguas nesta textualidade finalmente são tratadas como uma disciplina (LEM), ou é possível que neste fragmento esteja presente o desejo implícito de propiciar obrigatoriamente o estudo de somente uma LE, pois a língua nacional ainda estava em processo de supervalorização no território brasileiro.

Também se evidencia a falta de especificação de qual, ou quais língua (s) deveria (m) ser estudada (s). Outro fator relevante é a inclusão do adjetivo "moderna" à língua estrangeira, determinando nesse momento, a exclusão das línguas estrangeiras clássicas do currículo escolar brasileiro, a saber, o Latim e o Grego.

Por fim, tal obrigatoriedade se deu somente no $2^{\circ}$ grau, pois para o $1^{\circ}$ grau a inclusão do estudo de LEM foi apenas recomendada, onde as condições indicassem a necessidade de tal estudo e também permitissem, dando a seguinte ideia: "se for possível, se der, haverá o estudo de LEM, porém, caso não seja possível, não há problema”. Percebe-se que neste momento o estudo de LEM não se configurava em uma "necessidade" para alunos do $1^{\circ}$ grau, uma vez que neste nível educacional, à LEM é atribuído o papel de disciplina "complementar".

\subsubsection{A década de 80 e as primeiras iniciativas para a volta do Espanhol}

Como apresentado até este momento, o ensino de Espanhol no Brasil atravessou momentos de altos e baixos, sendo com o passar dos anos suprimido, e praticamente extinto da grade curricular das escolas brasileiras. No imaginário do cidadão brasileiro foi instituindose a crença de que "estudar Espanhol é fácil", e o Inglês foi se tornando "a" língua comercial, e assim, a LEM oferecida nas instituições de ensino, visto que o Francês aos poucos também foi perdendo seu espaço e as línguas clássicas, extintas do currículo em 1976. Contudo, alguns acontecimentos contribuíram para o retorno da língua espanhola em solo brasileiro.

No ano de 1979, em Niterói, foram criados os primeiros Centros de Estudos de Línguas Estrangeiras Modernas que logo chegaram aos estados de São Paulo e do Paraná. Em 
1985 foram criados os Centros de Línguas no Brasil ${ }^{45}$, na rede pública, que incluíam o ensino de Espanhol. Nesses momentos percebeu-se a transferência do ensino de Espanhol - de "responsabilidade" das escolas - a essas novas instituições de ensino.

No início dos anos 80 iniciam-se as tentativas para a volta do Espanhol aos currículos das escolas brasileiras com a criação das Associações Estaduais de professores de Espanhol (doravante APEs), quando, em 1981 foi criada a APEERJ - Associação de Professores de Espanhol do Estado do Rio de Janeiro, e em 1983 foi criada a APEESP - Associação de Professores de Espanhol do Estado de São Paulo ${ }^{46}$. Este movimento foi conseguindo reintroduzir o Espanhol ao currículo escolar, como conta Laseca (2008, p. 56), ao dizer que tal reintrodução se deu "mediante sua inclusão [do Espanhol] nos currículos de alguns Estados ${ }^{47}$ conseguindo que aparecesse entre as opções de língua estrangeira do Vestibular”, quando em 1986 a CESGRANRIO ofereceu aos candidatos do vestibular a opção pela língua espanhola na prova de LE. É válido destacar que, como afirma Camargo (2004, p. 142), dessas Associações de professores de Espanhol, no ano 2000 surgiu a Associação Brasileira de Hispanistas $^{48}$.

\subsubsection{A LDB de 1996}

Em dezembro de 1996 foi sancionada a Lei $\mathrm{n}^{\circ}$ 9.394, Lei de Diretrizes e Bases da Educação Nacional (doravante LDB/1996), que até os dias de hoje rege o sistema educacional do Brasil. Esta lei dividiu os níveis de escolarização em Ensino Fundamental (com 8 anos de duração) e Ensino Médio (com 3 anos de duração).

\footnotetext{
${ }^{45}$ No DF há oito Centros Interescolares de Línguas (CIL), criados entre 1975 e 1998. Dois localizam-se no Plano Piloto e os demais em outras localidades do DF: Brazlândia, Ceilândia, Gama, Guará, Sobradinho e Taguatinga. Essas escolas oferecem cursos de 3 a 6 anos das línguas: Alemão, Espanhol, Francês, Inglês e Japonês, sendo que cada CIL oferece pelo menos duas delas. A maioria oferece quatro línguas a seus alunos (MESQUITA, 2014).

46 Atualmente as APEs estão presentes em todos os estados brasileiros. No Distrito Federal, em 06 de abril de 1987 foi fundada a APEDF, Associação dos Professores de Espanhol do Distrito Federal, no Auditório do Instituto de Cultura Hispânica, atualmente sede do Instituto Cervantes de Brasília. No site da APEDF está sua definição, juntamente com seu principal objetivo: "É uma sociedade civil de direito privado, com prazo de duração indeterminado e sem fins lucrativos. Seu objetivo principal é facilitar o intercâmbio de informações e experiências entre os professores de espanhol do DF e promover sua atualização continuada. A exemplo das demais APEs no Brasil, seu trabalho contribui para tornar realidade a implantação da língua espanhola nas escolas brasileiras”. Informações disponíveis em:

$<$ http://www.apedf.com.br/>. Acesso em 12 de agosto de 2014.

${ }^{47} \mathrm{O}$ autor cita como exemplo a Lei Estadual 2.447/1995, do Rio de Janeiro, que declarou a obrigatoriedade do Espanhol nas escolas públicas no $1^{\circ}$ e $2^{\circ}$ grau.

${ }^{48}$ Para maiores informações: 〈www.hispanista.com.br〉. Acesso em 12de agosto de 2014.
} 
Valorizando a formação do aluno enquanto cidadão e indivíduo inserido em um mundo no qual a educação escolar deverá vincular-se ao mundo do trabalho e à prática social (Art. $1^{\circ}$ ), esta terceira LDB trouxe inovações em sua textualidade, porém ao mesmo tempo, continuou a carregar traços da LDB anterior (LDB/1971), publicada 25 anos antes.

Nesta nova lei foi devolvido às LEs o caráter obrigatório nos dois níveis de escolarização (Ensino Fundamental - a partir da quinta série) e Ensino Médio. Percebe-se um grande avanço na obrigatoriedade do Espanhol nos dois níveis de escolarização, pois, até esse momento, o Espanhol havia sido obrigatório somente em um nível.

É possível afirmar que por meio dessa lei, as LEs tiveram sua importância valorizada no sistema educacional, sendo sua inclusão um up ao ensino de línguas no Brasil. No documento (BRASIL, 1996, grifo meu), o Art. 26 traz uma nomenclatura um tanto quanto diferente ao afirmar que

Os currículos do ensino fundamental e médio devem ter uma base nacional comum, a ser complementada, em cada sistema de ensino e estabelecimento escolar, por uma parte diversificada, exigida pelas características regionais locais da sociedade, da cultura, da economia e da clientela.

$\mathrm{Na}$ última frase do fragmento acima, os sintagmas "economia" e "clientela" evidenciam que os conteúdos estudados na escola (neste caso especifico, na parte diversificada) também emergem da economia, situando o aluno a uma posição de cliente, e, dessa maneira, contribuindo para o conceito de educação = mercado. Logo, no próprio documento que nortearia a educação no Brasil é possível enxergar, ainda que de maneira sutil, certa visão mercantilista embutida nas decisões referentes às línguas estrangeiras.

No tocante às línguas estrangeiras, a lei (IBIDEM, grifo meu) especificou o seguinte:

Quadro 3 - As línguas estrangeiras na LDB de 1996 no Ensino Fundamental e Médio

\begin{tabular}{|l|l|}
\hline \multicolumn{1}{|c|}{ Ensino Fundamental } & \multicolumn{1}{c|}{ Ensino Médio } \\
\hline \multicolumn{1}{|c|}{${\text { Artigo } 26^{\circ} \text {, Parágrafo } 5^{\circ}}^{-1}$} & \multicolumn{1}{c|}{ Artigo $36^{\circ}$ - Inciso III } \\
\hline $\begin{array}{l}\text { [...] será incluído, obrigatoriamente, a partir da } 5^{\circ} \\
\text { serie, o ensino de pelo menos uma língua } \\
\text { estrangeira moderna, cuja escolha ficará a cargo da } \\
\text { comunidade escolar, dentro das possibilidades da } \\
\text { instituição. }\end{array}$ & $\begin{array}{l}\text { como disciplina obrigatória, escolhida pela } \\
\text { comunidade escolar, e uma segunda, em caráter }\end{array}$ \\
\hline
\end{tabular}

Fonte: Autoria própria 
No que se refere às LEs no Ensino Fundamental, a expressão "pelo menos" parece indicar uma quantidade mínima de LE a ser estudada, indicando que, caso haja condições de se oferecer mais de uma língua, assim poderá ser feito. Nesse sentido, até a publicação da lei, no Ensino Fundamental o Inglês preponderava de maneira praticamente absoluta. No Ensino Médio a situação era semelhante (com exceção das regiões fronteiriças com países de língua espanhola que, evidentemente, optavam pelo ensino-aprendizagem de Espanhol dadas as necessidades locais), porém, com a possibilidade de uma segunda língua, o campo de crescimento do Espanhol neste momento cresceu consideravelmente.

Nos dois níveis de ensino é atribuída a escolha das línguas estudadas à comunidade escolar. É válido ressaltar que o termo "comunidade escolar" aparece somente essas duas vezes na LDB/1996, ou seja, somente referente ao ensino de LE. Contudo, essa escolha da comunidade escolar está condicionada às possibilidades da instituição. Assim, ainda que a comunidade escolar opte por determinada língua, em última instancia, a decisão no tocante ao seu oferecimento acabará sendo da própria instituição de ensino.

Nos Parâmetros Curriculares Nacionais, publicado em 1998 (doravante PCNs), no momento de incluir uma LE como disciplina obrigatória ou optativa, sugere-se que se leve em conta:

1) Fatos históricos e de relevância das línguas nas relações internacionais (o documento cita os casos do Inglês e do Espanhol),

2) Fatores relacionados com as comunidades locais (se refere às línguas Indígenas e à Língua de Sinais),

3) Fatores tradicionais (no qual cita o Francês).

Considerando a visão de educação $=$ mercado e aluno $=$ clientela, bem como o predomínio do Inglês como LE seguido do Espanhol, pode-se constatar que os fatores que mais têm sido levados em consideração ao se escolher línguas para integrar a grade curricular atualmente são os fatores históricos e relativos às relações internacionais que o Brasil mantém em sua política externa.

Dois pontos de semelhança se apresentam entre a LDB/1996 e a anterior, LDB/1971. $\mathrm{O}$ primeiro diz respeito à não especificação das línguas a serem estudadas, que se mantém nesta nova lei. 
O segundo está presente no inciso IV do Art. 24, quando o documento (BRASIL, 1996) mais uma vez sugere que as escolas organizem "classes, ou turmas, com alunos de séries distintas, com níveis equivalentes de adiantamento na matéria, para o ensino de línguas estrangeiras, artes e outros componentes curriculares". Com textualidade muito semelhante à da LDB/1971, mais uma vez a legislação dissocia o estudo de LE das demais disciplinas, dando continuidade à visão, já enraizada, de LE como disciplina extracurricular.

Sobre a indeterminação das línguas a serem estudadas, Celada e Rodrigues (2005, p. 6) apontam a predominância do Inglês sobre as demais línguas, quando na verdade, essa opção poderia ser otimizada tendo em vista os limites de fronteira que caracterizam alguns estados brasileiros, como os Parâmetros Curriculares para o Ensino Médio (BRASIL, 2000, p. 27) já haviam sugerido. As autoras (CELADA e RODRIGUES, op. cit., p. 6) afirmam que

\begin{abstract}
A pesar de que la ley sigue la tónica de no predeterminar la lengua extranjera moderna, continua el predominio absoluto del inglês frente a todas las demás lenguas que, en teoría, se podrían ofrecer y que, de hecho, sobre todo en algunas regiones del país, podrían ser más importantes para algunas comunidades, como por ejemplo el español en áreas de frontera de los estados de Rio Grande do Sul, Santa Catarina y Paraná con países hispanohablantes, o el alemán en el interior de Santa Catarina, donde para parte de los alunos es lengua materna. [...] en las escuelas públicas el inglés es casi siempre la única lengua que se enseña... $[\ldots]^{49}$
\end{abstract}

Ao final desse fragmento, publicado meses antes da publicação da Lei 11.161/2005, as autoras evidenciam o panorama do ensino de línguas na escola pública até aquele momento: o Inglês como quase sempre a única língua que se ensina. Entretanto, esta realidade estava prestes a mudar, e o ensino de LEs no Brasil prestes a viver um momento único e singular: a valorização extrema de uma língua antes desprestigiada e à margem das demais, que brevemente seria a única língua a possuir legislação própria no Brasil.

Começam a emergir por meio de situações econômicas, sociais, culturais e políticas os antecedentes da Lei 11.161 de 2005: um novo status atribuído à língua espanhola como língua de comércio, de solidariedade com a América Latina, porém, sobretudo, obrigatoriamente como língua escolar.

\footnotetext{
49 “Apesar de que a lei segue a tônica de não pré-determinar a língua estrangeira moderna, continua o predomínio absoluto do inglês sobre todas as demais línguas que, em teoria, poderiam ser oferecidas e que, de fato, sobretudo em algumas regiões do país, poderiam ser mais importantes para algumas comunidades, como exemplo o espanhol em áreas de fronteira dos estados do Rio Grande do Sul, Santa Catarina e Paraná com países hispano falantes, o alemão no interior de Santa Catarina, onde para parte dos alunos é língua materna. [...] nas escolas públicas o inglês é quase sempre a única língua que se ensina...”. As traduções presentes nesta dissertação são de minha responsabilidade.
} 


\section{4 “A LEI, ORA A LEI ${ }^{50 \%: ~ D E S D O B R A M E N T O S ~ D A ~ L E I ~ 11.161 / 2005 ~}{ }^{51}$}

"A política linguística resume-se então a uma banal análise custo-benefício?"

(GRIN, 2005, p. 19)

\subsubsection{Antecedentes: A década de 90 e o "boom" do Espanhol}

Durante muito tempo o Brasil foi visto como o "gigante vecino que habla Portugués": um enorme país dotado de ricas diversidades culturais, com um extenso território e inúmeros habitantes, porém, o único de fala portuguesa em uma América Latina integrada, em sua maioria, por países de fala hispana (CELADA e RODRIGUES, 2005). Essa fronteira linguística entre o Brasil e seus vizinhos latino-americanos por vezes se tornou uma barreira entre o Brasil e os demais países da América Latina.

Contudo, de maneira "espetacular" e "muito diferente" (MORENO FERNÁNDEZ, 2005), no início da década de 90 o Espanhol começou a ascender em solo brasileiro, alcançando um crescimento muito significativo, nunca visto antes na história deste idioma no Brasil. Esta ascendência apresentou-se como a "mudança de um cenário que temos o privilégio de assistir: a influência da cultura e língua espanhola no mundo" (REATTO e BISSACO, 2007, p. 8). De fato, uma grande e verdadeira mudança, tendo em vista que até este momento o Espanhol no Brasil havia sido tratado como uma língua parecida, fácil e de estudo desnecessário, onde o "portunhol" supria as necessidades que pediam seu uso. Porém, essa realidade já remontava ao passado, abrindo portas para a crescente ascensão que a língua espanhola começava a atravessar.

Desse modo, a década de 90 ficou conhecida como o período do boom do Espanhol (AMARAL e MAZZARO, 2007, p. 1). Este boom ficou evidente em função de mudanças ocorridas em diversas instâncias, tais como a explosão dos cursos de Espanhol, uma vez que aumentava significativamente a oferta e procura por cursos dessa língua.

É nessa época que despontam as principais empresas já atuante no ensino de idiomas CCAA, Wizard e Fisk - , quando estas aderem ao Espanhol, espalhando-se pelo Brasil através do sistema de franquias (LASECA, 2008). Com a crescente oferta e procura por cursos de

\footnotetext{
50 Esta frase foi pronunciada em 1947 pelo então ex-presidente Getúlio Vargas, ironizando aqueles que abandonam a justiça. Essa frase tem estado presente no imaginário nacional quando se comenta o descumprimento de alguma lei , e já foi citada inúmeras vezes em referencia à implantação da Lei 11.161/2005.

${ }^{51}$ A publicação desta lei no Diário Oficial do dia 08 de agosto de 2005 encontra-se no anexo A.
} 
Espanhol, é nessa época também que se dá o boom na produção didática de língua espanhola (CAMARGO, 2004).

Este crescimento também chega às universidades: são criadas licenciaturas específicas em Espanhol, as disciplinas desta língua ganham mais espaço, e tal língua se torna objeto de estudo com o surgimento de cursos de pós-graduação (NOVODVORSKY et al, 2010, p. 35). Semelhantemente, a LA no início dos anos 90 também galgava espaço no Brasil, com programas de pós-graduação específicos na área de LA, como por exemplo, na UNICAMP, e desse modo, tem-se para a língua espanhola, mais espaço para a pesquisa (CAMARGO, 2004, p. 142). Viñal Junior (2012a, p. 9) descreve bem o crescimento da língua espanhola quando discorre que este interesse permanece atualmente, ao dizer que

[...] se "vende" o espanhol para um mercado consumidor em crescente ascensão, isso se vê através dos incontáveis centros de idiomas [...], nas universidades que muitas vezes oferecem o espanhol instrumental, em anúncios de jornal, em cursos de extensão, de imersão cultural, aulas particulares, viagens culturais, excursões e em preparações para provas de concurso e vestibular.

Contudo, a que se deveu tamanho crescimento e ascendência da língua espanhola no Brasil na década de 90, tendo esse prestígio se estendido ao século XXI e permanecido até os dias de hoje? Que motivos fizeram o imaginário do brasileiro começar a mudar e a ver no Espanhol um objeto de interesse? Quais motivos podem ser considerados os precursores para a implantação do Espanhol como disciplina obrigatória na rede pública e privada no ano de $2005 ?$

Por fim, Jaeger (2009, p. 33) levanta o questionamento que até hoje não quer calar: “que elemento terá desencadeado, finalmente, a aprovação por lei das reformas pretendidas há quase meio século atrás?”.

\subsubsection{Os precursores da Lei 11.161/2005}

Segundo Moreno Fernández (2005, p. 18), “a situação do espanhol no início do século XXI no Brasil é de auge e de prestígio". Muitos são os motivos que contribuíram para a ascensão do Espanhol, tratando-se principalmente, de motivos de ordem econômica, social e cultural do país, que refletiram no interesse pela língua espanhola.

Como bem afirmou Rajagopalan (2013), as políticas linguísticas não são elaboradas com base em fatos, mas com base em percepções. Dessa maneira, algumas causas são 
claramente perceptíveis para o prestígio do Espanhol no final do século XX e princípios do século XXI. Tais causas também podem ser apontadas como os elementos que faltaram nas tentativas anteriores para implantar o Espanhol no sistema educacional brasileiro, visto que toda decisão envolve uma escolha, e, como apresentado até este momento, no que se refere ao ensino de línguas no Brasil, escolhas necessitaram de motivações políticas. Logo, com o Espanhol não foi diferente.

Um fator inicial e que merece destaque foi e sempre será o estreitamento dos laços econômicos e políticos do Brasil com países de língua espanhola (Espanha e os "hermanos" latino-americanos). Tentativas de integração e cooperação entre principalmente, os países da América Latina, contribuíram para o crescimento do Espanhol no Brasil - ainda que muitas ações com esse propósito tenham ocorrido muito antes da década de 90, porém, por motivos diversos, não obtiveram êxito.

Para exemplificar, a primeira tentativa de integração da América Latina foi a Associação Latino-Americana de Livre Comércio (ALALC) em 1960, com o Tratado de Montevidéu, que em função de mudanças políticas - como a implantação de governos ditatoriais e interesses distintos entre argentinos e brasileiros -, não obteve êxito. Posteriormente, em 1969 idealizou-se o Pacto Andino, que também não obteve sucesso. Em 1978 o Brasil firmou o Tratado de Cooperação Amazônica (TCA) com sete países visando defender a região de interesses externos.

Como nenhuma dessas tentativas logrou êxito, em 1980 a ALALC foi substituída pela ALADI (Associação Latino-americana de Integração), com o objetivo de integrar o continente. Todavia, a década de 80 também não se apresentou favorável à realização dos objetivos da associação, tendo em vista as mudanças políticas nos países envolvidos. Após várias tentativas, somente no ano de 1991 estabeleceu-se o elemento de integração que durante décadas foi buscado entre os países da América Latina: a criação do Mercado Comum do Sul (doravante MERCOSUL).

\subsubsection{O MERCOSUL (1991) e os demais fatores econômicos e políticos}

Almejando mais uma vez a integração através de um bloco econômico entre os países latino-americanos, em 26 de março de 1991 foi assinado o Tratado de Assunção entre Brasil, 
Argentina, Paraguai e Uruguai ${ }^{52}$. O MERCOSUL implicou em uma livre circulação de bens, serviços e fatores produtivos, com o objetivo de facilitar as relações comerciais entre os países envolvidos. Celada e Rodrigues (2005, p. 2) afirmam que graças a essa integração foi possível recuperar certos sintagmas, "tales como "nuestra América, "la Pátria Grande”, "la América del Sur", "todo el continente americano", designando assim, um lugar comum, um encontro entre os países latino-americanos. Este Tratado além de objetivar a adoção de um mercado de consumo unificado e livre com tarifa zero entre os membros, juntamente com a aproximação dos países participantes somada à globalização que avançava a passos largos, gerou grandes impactos no âmbito linguístico em terras brasileiras.

O Art. 17 do Tratado (Tratado de Assunção, 1991, grifo meu) estabelece que "os idiomas oficias do Mercado Comum serão o espanhol e o português e a versão oficial dos documentos de trabalho será a do idioma do país sede de cada reunião". Ainda em dezembro de 1991 são assinados dois protocolos: Protocolo de Intenções (13 de dezembro) e o Protocolo de Brasília ${ }^{53}$ (17 de dezembro).

É válido discorrer brevemente sobre o Protocolo de Intenções, pois este, assinado pelos ministros de Educação dos Estados-membros, delineou a visão dos países sobre a educação e a realização de programas para orientar a politica cultural e educativa. Uma das orientações presentes neste documento (Protocolo de Intenções, 1991, grifo meu) foi “difundir a aprendizagem dos idiomas oficiais das comunidades - espanhol e português - nos sistemas educativos formais, não formais e informais".

Neste momento, torna-se evidente como as políticas linguísticas são abarcadas também para beneficiar relações comerciais de políticas externas, uma vez que o Brasil, único país do bloco que não possuía o Espanhol como LM, se comprometia com a difusão do ensino de língua espanhola em seu território. Logo, a criação do MERCOSUL demandou a necessidade de uma política linguística com relação ao Espanhol no Brasil, o que contribuiu grandemente para a valorização dessa língua no território nacional, que somente cresceu nos

\footnotetext{
${ }^{52}$ Em julho de 2012 a Venezuela passou a integrar o MERCOSUL e, em dezembro do mesmo ano, foi assinado o Protocolo de Adesão da Bolívia ao MERCOSUL. Com a ampliação, o bloco passou a contar com uma população de 270 milhões de habitantes e um PIB em torno de US\$ 3 trilhões, o equivalente a cerca de $80 \%$ do PIB sul-americano e $70 \%$ da população da América do Sul. Informações retiradas do site do Ministério do Desenvolvimento, Indústria e Comércio Exterior, disponível em: $\langle$ http://www.mdci.gov.br/sitio/interna/interna.php?area=5\&menu=538>. Acesso em 12 de agosto de 2014.

${ }^{53}$ Além dos dois protocolos citados, foram assinados outros dois: Protocolo de Ouro Preto, (Decreto Legislativo $\mathrm{n}^{\mathrm{o}}$ 188, de 16.12.95 e Decreto $\mathrm{n}^{\circ}$ 1.901, de 09.05.96) e Protocolo de Olivos (Decreto Legislativo $\mathrm{n}^{\mathrm{o}} 712$, de 15.10.2003 e Decreto ${ }^{\circ}$ 4.982, de 09.02.2004).
} 
anos posteriores. Celada e Rodrigues (2005, p. 3, grifo meu) descrevem essa transição de momentos com detalhes ao concluírem que

\begin{abstract}
[...] lo que primó en la relación del brasileño con esa lengua fue el hecho de que, históricamente, en el horizonte de las lenguas extranjeras, no llegó a ocupar un "lugar" y con esto queremos decir que no llegó a ser objeto de un supuesto saber por el que valiera la pena el trabajo de someterse a su estudio. Esto, de alguna forma, potenció el impacto que tuvieron los primeros movimientos relativos a la implementación del Tratado del Mercosur en lo que se refiere al estudio masivo del español, aunque no podamos decir que éste fuera el único elemento desencadenante del cambio al que nos referimos. Lo cierto es que el español pasó a formar parte del horizonte de las lenguas extranjeras como una lengua vehicular: como una lengua de los negocios, del trabajo y, también, como un pasaporte internacional (hacia la Unión Europea y hacia Estados Unidos). De esta forma, el acontecimiento del Mercosur (junto a una serie de factores) estimuló el abandono de la vieja rutina del brasileño. Tanto, que [...] se llegó a decir de diversas maneras: Não basta o portunhol para fazer o Mercosur..$^{54}$
\end{abstract}

Neste fragmento as autoras remontam ao imaginário que o brasileiro possuía acerca do Espanhol, e em função dessas antigas concepções, o impacto do Tratado de Assunção foi considerável no Brasil, desencadeando um novo momento para a língua espanhola que passou a ser vista como uma língua de trabalho e dos negócios, um verdadeiro passaporte internacional. Em concordância com este pensamento, ao discorrer sobre a posição da língua espanhola no mundo no início do século XXI, Sedycias $(2005$, p. 36) afirma que "é de tal importância que quem decidir ignorá-la não poderá fazê-lo sem correr o risco de perder muitas oportunidades de cunho comercial, econômico, cultural, acadêmico ou pessoal". Assim, é nesse momento que a língua espanhola vai galgando lugares de prestígio no Brasil e começa a ser vista mais como é, e não como o brasileiro pensa que ela é (SANTOS, 2002).

Cabe destacar que após a criação do MERCOSUL outros acordos linguísticos ${ }^{55}$ foram firmados, como novas tentativas de integração entre os países da América Latina, com os

\footnotetext{
54 “O que primou na relação do brasileiro com essa língua foi o fato de que, historicamente, no horizonte das línguas estrangeiras, não chegou a ocupar um "lugar", e com isto queremos dizer que não chegou a ser objeto de um suposto saber pelo qual valesse a pena o trabalho de submeter-se ao seu estudo. Isto, de alguma forma, potenciou o impacto que tiveram os primeiros movimentos relativos à implantação do Tratado do Mercosul no que se refere ao estudo massivo do espanhol, embora não possamos dizer que esse fosse o único elemento desencadeante da mudança a que nos referimos. O certo é que o espanhol passou a formar parte do horizonte das línguas estrangeiras como uma língua veicular; como uma língua dos negócios, do trabalho e, também, como um passaporte internacional (em direção a União Europeia e até os Estados Unidos). Desta forma, o acontecimento do Mercosul (junto a uma série de fatores) estimulou o abandono da velha rotina do brasileiro. Tanto que [...] se chegou a dizer de diversas maneiras: Não basta o portunhol para fazer o Mercosul!".

${ }^{55}$ Como por exemplo, o Acordo de Integração Cultural Brasil-Argentina - 1997, que parágrafo no 2 do Art. $1^{\circ}$ firma que cada uma das partes, com base na reciprocidade, apoiaria atividades para a difusão do idioma e expressões culturais do outro Estado. Outro exemplo é o Projeto de Decreto Legislativo $n^{o} 465-A$, de 2000, um
} 
quais, cada vez mais o Brasil se comprometia a difundir, promover e estimular o ensino de Espanhol em suas instituições de ensino.

Conforme as considerações feitas sobre o MERCOSUL, o bloco econômico constantemente é considerado o ápice precursor para a implementação do Espanhol no Brasil. De fato, sua influência é inegavelmente clara. Contudo, não se pode atribuir ao Tratado de 1991 a exclusividade de precursor da obrigatoriedade do ensino de Espanhol no Brasil.

Tal motivação, segundo González (2009), consiste em um "estereótipo usado pelos incentivadores desse ensino e fortemente explorado pela publicidade das escolas de línguas". Portanto, muitos outros fatores "abriram caminho" à Lei 11.161 de 2005, sendo a maioria deles - em sua essência -, de ordem econômica e política, tendo o governo espanhol um papel de destaque. Dentre esses fatores, cabe destacar a chegada de empresas espanholas no Brasil e a geração de fortes investimentos econômicos.

A chegada de empresas espanholas no Brasil: Nessa época, o Brasil se tornou uma excelente aposta de investimentos, tendo em vista seu crescimento comercial. Assim, chegaram ao Brasil grandes empresas espanholas com investimentos econômicos na iniciativa privada brasileira. Empresas como a Telefônica, a seguradora Mapfre, os bancos Santander e Bilbao Viscaya e a rede de postos Repsol YPF investiam no Brasil. Rapidamente, eram mais de 454 empresas espanholas associadas investindo em terras brasileiras (REATTO e BISSACO, 2007).

Os fortes investimentos da Espanha no Brasil: A Espanha, detentora de uma poderosa indústria cultural e editorial, através de seu crescimento econômico tornou-se o segundo maior investidor no Brasil (atrás somente dos Estados Unidos), tendo esses investimentos aumentado consideravelmente após a criação do MERCOSUL, visto que o Brasil ascendia internacionalmente como "país líder"

Conforme afirma Lodares (apud JAEGER, 2009), a inclusão brasileira na comunidade linguística hispânica proporcionaria a inclusão de mais de 170 milhões de consumidores potenciais de bens e serviços referentes ao Espanhol enquanto idioma.

\section{Presença de instituições espanholas e a difusão do Espanhol no Brasil:}

Instituto Cervantes: O Instituto Cervantes (doravante IC) foi criado em 1991 e

acordo entre o Brasil e a Bolívia, nas quais as partes procurarão estimular como opção de língua estrangeira nos currículos de nível médio e superior o ensino de idioma da outra parte.

${ }^{56}$ Neste pensamento, Juan Arias (2004, grifo meu) se pronuncia no El País, conhecido periódico espanhol: "Se o Brasil quiser liderar não só o Mercosul, mas também, de alguma forma, exercer uma forte liderança em toda a América Latina, tem que falar espanhol". 
chegou ao Brasil ${ }^{57}$ no mesmo ano, na cidade de São Paulo. Órgão oficial do Ministério de Educação da Espanha, o IC possui um papel político, pois tem como objetivo a difusão do Espanhol fora do seu território, "promover, ensinar espanhol e difundir a cultura da Espanha e dos outros países hispanofalantes ${ }^{58}$ ". A instituição também se encarrega de organizar exames de proficiência de Espanhol como LE (DELE ${ }^{59}$ - Diploma de Espanhol como Língua Estrangeira), ministrar cursos de Espanhol, dar apoio a hispanistas e desenvolver atividades culturais juntamente com outras organizações.

Consejería de Educación de España en Brasil: A Consejería de Educación "se encarga de gestionar las políticas educativa y cientifica de España en Brasil ${ }^{60}$ ". Centraliza suas atividades na atualização didática, entre universidades brasileiras e espanholas.

Asociación Española de Cooperación Internacional e Desarrollo (AECID): Criada há 26 anos, tem como prioridades a promoção do desenvolvimento e do equilíbrio nas relações internacionais, bem como "la prevención y atención de situaciones de emergencia, la promoción de la democracia y el impulso de las relaciones con los países sócios ${ }^{61 "}$. Esta associação também está relacionada à educação, visto que contribui para a formação de professores brasileiros através de seu programa de bolsas.

Cabe por fim, salientar o aumento da produção didática em Espanhol, uma vez que com o aumento dos cursos de Espanhol no Brasil, a produção editorial relativa ao ensino desta língua também cresceu consideravelmente.

Dessa maneira, dentro do contexto apresentado, no dia 05 de agosto de 2005 ocorreu um marco: um acontecimento discursivo que rompeu com a memória de não especificação das línguas estrangeiras, pois surge para delimitar o lugar de uma língua: a espanhola (LEMOS, 2008, p. 77).

\subsubsection{A sanção da Lei 11.161/2005 e suas implicações}

A Lei 11.161 de agosto de 2005 resultou do Projeto de Lei (PL) n 3.987/2000

\footnotetext{
${ }^{57}$ O IC chegou ao Brasil no mesmo ano da criação do MERCOSUL (1991), valorizando ainda mais a presença da língua espanhola.

${ }^{58}$ Retirado do site da instituição. Disponível em: <http://saopaulo.cervantes.es/br/sobre_nos.htm>. Acesso em 12 de agosto de 2014.

59 Segundo Moreno Fernández (2005, p. 29), o DELE tem no Brasil 45\% de participação total em suas convocatórias a cada semestre. Dessa maneira, é no Brasil que ocorre sua maior demanda mundial.

${ }^{60}$ Retirado do site da instituição. Disponível em: <www.mw cd.gob.es/brasil/>. Acesso em 12 de agosto de 2014.

${ }^{61}$ Retirado do site da instituição. Disponível em: <www.aecid.es/ES/la-aecid>. Acesso em 12 de agosto de 2014.
} 
proposto pelo deputado Átila Lira, em 2000. Este PL passou por tramitações na Câmara dos Deputados e no Senado Federal, com emendas e alterações, convertendo-se cinco anos depois na lei que ficou conhecida como a "Lei do Espanhol"

$\mathrm{Na}$ justificação $^{63}$ deste PL o deputado Átila Lira afirma que naquela época a importância do Espanhol mundialmente era indiscutível. O Brasil, rodeado por países hispanohablantes, havia se tornado uma ilha, e, com o advento do MERCOSUL, "aumenta a necessidade de se conhecer a língua espanhola" (BRASIL, 2000).

Átila Lira nos remete ao histórico do ensino de Espanhol no Brasil: sua inclusão em 1942; sua exclusão em 1961, o encargo dado ao Conselho Federal de Educação para fixar os currículos mínimos em 1971, e cita a Constituição Federal de 1988, que determinou que o Brasil deveria buscar a integração econômica, política, social e cultural dos povos da América Latina. Por fim, cita a importância dada ao ensino de línguas estrangeiras na LDB/1996 e as tentativas frustradas de implantar o Espanhol no Brasil, onde justifica porque destaca a língua espanhola (BRASIL, 2000): proximidade de compreensão, aproximação geográfica com os países latino-americanos, publicações na língua espanhola e ampliação de oportunidades na comunicação global.

Rajagopalan (2013, p. 29) afirma que a política linguística é sempre datada e contextualizada, podendo ser caracterizada como bem acertada ou mal pensada, apropriada ou precipitada. Do mesmo modo, a "Lei do Espanhol" no contexto histórico e social no qual foi implementada, foi valorizada, mas ao mesmo tempo trouxe inúmeras polêmicas; desafios, questionamentos e indignações, gerando grande repercussão nos meios de comunicação, na academia e nas entidades que representavam os professores de Espanhol em diversos estados brasileiros. O Espanhol, como disciplina, "nunca esteve tão claramente associada a um gesto marcado de forma inequívoca por um objetivo cultural, político e econômico" (MEC/SEB, 2006, p. 127, grifo meu).

Com base nisso, a seguir, apresento a Lei 11.161 de 2005, na íntegra de sua textualidade, para posteriormente discorrer sobre seu conteúdo.

\footnotetext{
${ }^{62}$ Levando em consideração os fatores externos para a implementação da lei e as implicações da mesma, acredito que esta nomenclatura (Lei do Espanhol) seja um tanto quanto inequívoca, pois, apesar de ser uma legislação referente à língua espanhola de maneira pontual, gerou impacto no ensino de línguas estrangeiras como um todo no Brasil, afetando assim, o ensino de outros idiomas também.

${ }^{63}$ A Proposição e a Justificação deste PL estão disponíveis no site da Câmara na sessão "Publicações e Estudos" em <http://www2.camara.gov.br/pblicacoes $>$., bem como nos anexos B e C, respectivamente. Acesso em 15 de setembro de 2013.
} 


\subsubsection{A Lei 11.161/2005}

LEI No 11.161, DE 5 DE AGOSTO DE 2005.

Dispõe sobre o ensino da língua espanhola

O PRESIDENTE DA REPÚBLICA Faço saber que o Congresso Nacional decreta e eu sanciono a seguinte Lei:

Art. $1^{\circ} \mathrm{O}$ ensino da língua espanhola, de oferta obrigatória pela escola e de matrícula facultativa para o aluno, será implantado, gradativamente, nos currículos plenos do ensino médio.

$\S 1^{\circ} \mathrm{O}$ processo de implantação deverá estar concluído no prazo de cinco anos, a partir da implantação desta Lei.

$\S 2^{\circ}$ É facultada a inclusão da língua espanhola nos currículos plenos do ensino fundamental de $5^{\mathrm{a}}$ a $8^{\mathrm{a}}$ séries.

Art. $2^{\circ} \mathrm{A}$ oferta da língua espanhola pelas redes públicas de ensino deverá ser feita no horário regular de aula dos alunos.

Art. $3^{\circ}$ Os sistemas públicos de ensino implantarão Centros de Ensino de Língua Estrangeira, cuja programação incluirá, necessariamente, a oferta de língua espanhola.

Art. $4^{\circ}$ A rede privada poderá tornar disponível esta oferta por meio de diferentes estratégias que incluam desde aulas convencionais no horário normal dos alunos até a matrícula em cursos e Centro de Estudos de Língua Moderna.

Art. $5^{\circ}$ Os Conselhos Estaduais de Educação e do Distrito Federal emitirão as normas necessárias à execução desta Lei, de acordo com as condições e peculiaridades de cada unidade federada.

Art. $6^{\circ}$ A União, no âmbito da política nacional de educação, estimulará e apoiará os sistemas estaduais e do Distrito Federal na execução desta Lei.

Art. $7^{\circ}$ Esta Lei entra em vigor na data da sua publicação.

Brasília, 5 de agosto de 2005; $184^{\circ}$ da Independência e $117^{\circ}$ da República.

\section{LUIZ INÁCIO LULA DA SILVA \\ Fernando Haddad}

Conforme as considerações feitas acerca do PL de Átila Lira convertido na Lei acima, vê-se que o discurso inicial para a implantação do Espanhol no Brasil justificou-se pelo alcance mundial desta língua (que já ocupava o segundo lugar como elemento de comunicação no mercado internacional) e pela integração do Brasil com os países hispânicos. 
Essas duas motivações situam-se na esfera política, embora se tenha de forma breve, citado a necessidade de aprendizado dessa língua.

A discursividade da justificação somada ao contexto aqui apresentado gera o entendimento de que não se tratou de uma questão legitimamente educacional, mas de uma questão econômica e política de caráter urgente, reforçado pela frase que fecha a justificação (BRASIL, 2000, grifo meu): “[...] cientes da importância da língua espanhola para a integração cultural, econômica e social do Brasil com os demais países [hispânicos], unam-se pela urgência de aprovação desse projeto".

Nesse sentido, vários meios de comunicação (jornais, revistas, periódicos, publicações on-line, etc) expressaram-se sobre o assunto, suscitando opiniões diversas sobre a obrigatoriedade do Espanhol, uma vez que todas as instituições de ensino privadas e públicas do país teriam somente cinco anos para adequar-se à lei, ou seja, um grande esforço teria que ser desprendido pelos formadores, alunos e gestores públicos para alcançar a meta da implementação e atender às demandas sociais que este ato político exigiria, tendo em vista o total despreparo da maioria dos estados brasileiros.

Assim, iniciou-se uma corrida contra o tempo, na qual diversos foram os desafios encontrados no meio do caminho, tais como boa vontade dos Estados para a implantação e falta de ações governamentais nos níveis municipais e estaduais.

Muitas reações negativas ocorreram no tocante à planificação governamental (ação, execução da lei) referente também à formação de professores de Espanhol no Brasil, uma vez que havia carência desses docentes, bem como formações inadequadas (ou até mesmo, inexistentes). Antes mesmo da implantação da lei, começou a ocorrer uma verdadeira guerra de cifras referente a quantos professores de Espanhol seriam necessários no Brasil. Laseca, (2008, p. 74), faz um levantamento dos números que circularam em diversos âmbitos (tanto no Brasil como em outros países) e a variação foi gritante: de 6.627 a 250.000 professores. O autor, por fim, conclui: "ou não estamos calculando o mesmo, ou estamos calculando mal" (IBIDEM, p. 76).

Finalmente, a própria lei e sua discursividade insípida; ambígua, confusa e passível de várias interpretações também se tornou um grande elemento de dificuldade, uma vez que em função das diversas interpretações possíveis, diferentes foram as medidas tomadas pelos estados brasileiros na implantação do Espanhol, como demonstrarei a seguir. 


\subsubsection{A Lei 11.161/2005 e o teor de sua textualidade}

Após situar a sanção da Lei 11.161/2005 em um contexto histórico-social, neste momento discorrerei sobre a textualidade da referida lei, de modo a interpretar ${ }^{\mathbf{6 4}}$ seu teor explícito e as implicações implícitas por trás de cada artigo e parágrafo, visto que coincido com May (2004) quando afirma que há significados “embutidos" nos documentos. Trata-se de uma análise breve e não exaustiva, com o intuito de suscitar possíveis entendimentos da lei e suas repercussões. Visando uma melhor compreensão, dividi a textualidade da lei em três blocos: a) os artigos $1^{\circ}$ e $7^{\circ}$; b) os artigos $2^{\circ}, 3^{\circ}$ e $4^{\circ}$ e c) os $\operatorname{artigos} 5^{\circ}$ e $6^{\circ}$.

O primeiro ponto que julgo considerável é a brevidade da lei, sete artigos e menos de uma página. $\mathrm{O}$ fato de uma legislação ser curta não implica em um problema, contudo, tal brevidade abriu margem para inúmeras interpretações de artigos não muito claros e até mesmo, confusos. Por tratar-se de uma lei federal, coube aos Conselhos Estaduais e Municipais de Educação promover sua regulamentação considerando as possibilidades e necessidades regionais. Porém, dada a multiplicidade de interpretações que a Lei 11.161/2005 possibilitou, muitos estados tomaram medidas e ações governamentais diferentes.

\subsubsection{Os artigos $1^{\circ}$ e $7^{\circ}$}

Art. $1^{\circ} \mathrm{O}$ ensino da língua espanhola, de oferta obrigatória pela escola e de matrícula facultativa para o aluno, será implantado, gradativamente, nos currículos plenos do ensino médio.

$\S 1^{\circ} \mathrm{O}$ processo de implantação deverá estar concluído no prazo de cinco anos, a partir da implantação desta Lei.

$\S 2^{\circ}$ É facultada a inclusão da língua espanhola nos currículos plenos do ensino fundamental de $5^{\mathrm{a}}$ a $8^{\mathrm{a}}$ séries.

Art. $7^{\circ}$ Esta Lei entra em vigor na data da sua publicação. (Grifos meus).

O Art. $1^{\circ}$ da Lei 11.161 resume o conteúdo legislado, visto que traz as orientações acerca do objeto que está tratando (a obrigatoriedade da língua espanhola), lócus (nos currículos plenos do Ensino Médio), maneira (de oferta obrigatória pela escola e de matrícula facultativa pelo aluno) e temporalidade (gradativamente, porém, devendo a implantação estar concluída no prazo de cinco anos). Percebe-se o caráter imperativo desta Lei: o ensino de Espanhol será implantado, e a implantação deverá estar concluída em cinco anos.

\footnotetext{
${ }^{64}$ No Capítulo 3 desta dissertação exponho minha visão de como interpretar um documento por meio da Análise Documental, e as implicações deste ato interpretativo.
} 
Observo que há uma relação paradoxal no que tange à oferta obrigatória e à matrícula facultativa para o aluno, visto que esta especificação reforça a não-obrigatoriedade da disciplina. Dessa maneira, o artigo $1^{\circ}$, ainda que de forma implícita, situa um lugar para o Espanhol como disciplina, mas, ainda assim, a língua continua carregando o traço de optativa.

A obrigatoriedade do Espanhol foi uma das maiores polêmicas geradas por esta lei, em função das diferentes interpretações atribuídas pelos meios de comunicação e pelos Conselhos Estaduais e Municipais de Educação. Não somente isso, grandes foram as dúvidas e apreensões pelo fato da lei entrar em relação direta com as normativas da LDB/1996, que já estipulava a obrigatoriedade de uma "língua estrangeira moderna", porém, escolhida pela comunidade (BRASIL, 1996). Logo, a escolha de uma língua pela comunidade escolar (LDB/1996) e a oferta obrigatória do Espanhol (Lei 11.161) configuraram-se como uma problemática contradição para a implantação do Espanhol, resultando em medidas diferentes nos Estados brasileiros.

O segundo fator gerador de ambiguidades e diferentes medidas governamentais diz respeito ao sintagma "gradativamente", retomado no parágrafo $1^{\circ}$, que determina que "o processo de implantação deverá estar concluído no prazo de cinco anos, a partir da implantação desta Lei”. Como afirma Viñal Júnior (2012a, p. 9), “essa questão de prazo deixou diversos estados da Federação com uma interpretação a seu critério", sendo esta questão interpretada de acordo com as conveniências de cada Conselho Estadual de Educação.

Estados como o Mato Grosso e o Mato Grosso do Sul regulamentaram a lei em 2006 e 2007, pois entenderam que até 2010 o idioma deveria estar sendo lecionado no Ensino Médio. Contudo, outros estados (provavelmente a maioria) como Minas Gerais e Rio de Janeiro interpretaram os "cinco anos a partir da implantação desta Lei" como o prazo para começar a cumpri-la, sendo iniciada a implantação somente em 2010. Cabe salientar a interpretação dada pelo Estado de São Paulo a este artigo, uma vez que o governo do Estado noticiou em janeiro de 2010 que iniciaria a oferta do Espanhol somente em agosto de 2010, pois o prazo para a execução era cinco anos $\left(\right.$ Art. $\left.1^{\circ}\right)$ e a lei entrava em vigor no dia 08 de agosto de 2005 (Art. $7^{\circ}$ ). Tal atitude demonstra como alguns estados, lançando mão de verdadeiras manobras, adiaram a implantação do Espanhol até os últimos momentos do prazo final.

Outro ponto confuso está presente no parágrafo $1^{\circ}$, em função das diferentes funções atribuídas ao sintagma implantação: “O processo de implantação deverá estar concluído no prazo de cinco anos, a partir da implantação desta Lei”. Com base neste fragmento, surge a 
pergunta: qual a data específica da implantação da Lei 11.161: no dia 08 de agosto de 2005, dia de sua publicação? O primeiro dia do ano de 2010? Dia 08 de agosto de 2010? Caso a implantação se desse somente em 2010 (como alguns estados interpretaram), os Estados ainda teriam cinco anos para implantar a lei, chegando a 2015? Obviamente todas essas alternativas (algumas um tanto quanto absurdas) não passam de possíveis interpretações, porém, o fato é: o que julgar como implantação tendo em vista que a textualidade da própria lei não especifica claramente?

Por fim, o parágrafo $2^{\circ}$ do artigo $1^{\circ}$ torna o ensino de Espanhol facultativo nas últimas séries do Ensino Fundamental ( $5^{\mathrm{a}}$ a $8^{\mathrm{a}}$ serie). Aqui, vale considerar a Lei 11.274 de 6 de fevereiro de 2006, que ampliou o Ensino Fundamental para nove anos, devendo a implantação ocorrer até 2010. Essa possibilidade pareceu interessante, pois os alunos dessas séries do Ensino Fundamental são quase o dobro dos alunos do Ensino Médio. Logo, segundo Laseca (2008, p. 67) seria "um universo de mais de 25 milhões de possíveis alunos de espanhol".

\subsubsection{Os artigos $2^{\circ}, 3^{\circ}$ e $4^{\circ}$}

Art. $2^{\circ} \mathrm{A}$ oferta da língua espanhola pelas redes públicas de ensino deverá ser feita no horário regular de aula dos alunos.

Art. $3^{\circ}$ Os sistemas públicos de ensino implantarão Centros de Ensino de Língua Estrangeira, cuja programação incluirá, necessariamente, a oferta de língua espanhola.

Art. $4^{\circ}$ A rede privada poderá tornar disponível esta oferta por meio de diferentes estratégias que incluam desde aulas convencionais no horário normal dos alunos até a matrícula em cursos e Centro de Estudos de Língua Moderna. (Grifos meus).

Em semelhança aos artigos já analisados, os artigos $2^{\circ}, 3^{\circ}$ e $4^{\circ}$ também possibilitaram diversas interpretações.

O Art. $2^{\circ}$ afirma que as escolas públicas deverão oferecer o ensino de Espanhol no horário regular de aula dos alunos. Entretanto, neste fragmento não se deixa claro o que de fato, deveria ser considerado como "horário regular". Tal indeterminação gerou a reflexão de como a escola pública garantiria a liberdade de escolha dada aos alunos, ao passo em que administraria problemas logísticos (tais como espaço físico, recursos, mudanças na grade curricular, distribuição de professores e alunos, entre outros). A escola pública, de fato, estaria em condições de facultar este ensino tendo em vista as reais condições apresentadas no sistema educacional público brasileiro? 
Como se já não estivesse arbitrário o suficiente, o Art. $2^{\circ}$ ainda entra em contradição com o Art. $3^{\circ}$, que determina que as escolas públicas implantarão "centros de ensino de língua estrangeira, cuja programação incluirá, necessariamente, a oferta de língua espanhola". Analisando os dois artigos, outros questionamentos podem ser feitos: Onde afinal, os alunos da rede pública estudariam o Espanhol: na escola regular ou no centro de línguas? Haveria a opção de optar entre um ou outro lugar? Poderiam estudar o Espanhol na escola regular e nos centros de línguas? Poderiam estudar no centro de línguas no horário das aulas regulares na escola?

Neste ponto, mais uma vez, em função das ambiguidades e arbitrariedade da legislação, houve medidas diferentes de um estado para o outro. No Mato Grosso do Sul, por exemplo, a expressão "horário regular" significa o turno no qual o aluno está matriculado. Já em Minas Gerais esse horário seria em contra turno ao que o aluno estiver matriculado, ou no $6^{\mathrm{o}}$ horário do turno diurno. Neste estado especificamente, a lei abriu "a possibilidade de deslocar, para um horário extra uma disciplina que, em alguns casos, já estava razoavelmente consolidada no currículo escolar" (AMARAL e ALMEIDA, 2010, p. 316), fazendo com que muitos alunos desistissem da disciplina ou não tivessem turmas de Espanhol, pois de acordo com a Orientação DEMP/SEM/SB nº 01/2009, se escolhida pelo aluno, a língua espanhola deveria ser ofertada em turmas de no mínimo, 25 alunos.

Mais uma vez a própria lei contribui para o caráter "extracurricular" que tanto acompanhou o ensino de Espanhol no Brasil. Contudo, a possibilidade de incluir o Espanhol fora da grade curricular "infringe las propuestas del Mercosur, que prevé la inclusión de las lenguas española y portuguesa em las escuelas de los países miembros" (CELADA e RODRIGUES, 2005, p. 7).

Segundo os Parâmetros Curriculares nacionais para o Ensino Médio (doravante PCNEM), em uma das partes destinadas ao ensino de LE o documento estabelece o lugar das línguas ensinadas na escola, ao afirmar que "as línguas estrangeiras assumem a condição de serem parte indissolúvel do conjunto de conhecimentos essenciais que permitem ao estudante aproximar-se de várias culturas [...]" (BRASIL, 2000, p. 25 grifo meu). Como parte indissolúvel, por que a legislação abriu precedentes para o ensino de Espanhol de maneira extra-curricular, de forma desarticulada com as demais disciplinas da grade curricular? Como bem afirma Fernández (2014, p. 19), "para que se alcance essa finalidade mais "utilitária" dos idiomas estrangeiros é necessário que seu ensino esteja articulado às outras disciplinas que integram o currículo". 
Posteriormente, o Edital PNLD 2011 (Programa Nacional do Livro Didático) reafirma o anseio de ver as LEs dentro da grade curricular, ao afirmar que a distribuição de livros didáticos de Espanhol e Inglês para as escolas públicas deveria contribuir, também, para que as escolas elaborassem projetos político-pedagógicos que “integrem ao máximo o ensino dessas línguas em suas grades, com propostas de trabalho de qualidade, garantindo, para as línguas estrangeiras, distribuição de carga horária justa e adequada” (Guia PNLD 2011, p. 13). Logo, antes e depois da sanção da Lei 11.161/2005 havia documentos que indicavam onde se deveria aprender língua estrangeira: na escola. Essas questões levantam o seguinte questionamento: até que ponto os documentos oficiais relativos ao ensino de LEs (como os PCNs, PCNEM e a LDB/1996) foram levados em consideração na formulação da Lei $11.161 / 2005$ ?

Os artigos $3^{\circ}$ e $4^{\circ}$, combinados, estabelecem claras diferenças entre a rede pública e privada, pois segundo a lei, as escolas públicas deveriam oferecer o ensino de Espanhol no horário regular (Art. $2^{\circ}$ ) e/ou nos Centros de Ensino de língua estrangeira (Art. $3^{\circ}$ ), ao passo em que as escolas privadas poderiam utilizar "diferentes estratégias que incluam desde aulas convencionais no horário normal dos alunos até a matrícula em cursos e Centros de Estudos de Línguas Modernas" (Art. $4^{\circ}$ ).

Nesse sentido, cabe refletir na possibilidade da Lei 11.161/2005 estar promovendo a desigualdade, visto que a língua é também um "elemento de comunicação e reflexo social que pode exercer poder, exercer dissensão, exercer discriminação" (VIÑAL JÚNIOR, 2012a, p. 5). Logo, por que a lei estabelece orientações distintas para redes privadas e públicas? Por que diferenciar alunos da escola pública e da escola privada? Seria esta diferenciação o reconhecimento oficial da diferença de qualidade entre um ensino e outro? De fato, "parece que la ley no mide la cosa con el mismo rasero" (VIÑAL JÚNIOR, 2012b, p.2).

\subsubsection{Os artigos $5^{\circ}$ e $6^{\circ}$}

Art. $5^{\circ}$ Os Conselhos Estaduais de Educação e do Distrito Federal emitirão as normas necessárias à execução desta Lei, de acordo com as condições e peculiaridades de cada unidade federada.

Art. $6^{\circ}$ A União, no âmbito da política nacional de educação, estimulará e apoiará os sistemas estaduais e do Distrito Federal na execução desta Lei. 
Nesses artigos se estabelece quem regulamentará as normas necessárias para a execução da lei: os Conselhos Estaduais de Educação. Como já demonstrado nesta dissertação, esses conselhos, criados em 1961, são responsáveis pela regulamentação da Legislação educacional em nível estadual. Para Rodrigues (2010a, p. 153), estes dois artigos funcionam como "tentativas" do Poder Legislativo de controlar a execução da lei, visto que o cumprimento da mesma lhe escapa.

Além disso, este fragmento, ao atribuir aos CEE's a responsabilidade de executar a lei sem perder de vista as condições e peculiaridades de cada região, parece abrir precedentes para que cada ente federado interprete a lei da forma que melhor lhe convir, o que de fato, aconteceu.

\subsubsection{O Conselho Estadual de Educação de Sergipe e o Parecer nº 18/2007}

Tendo em vista a necessidade de regulamentação da Lei 11.161/2005 e as dúvidas geradas pela textualidade da mesma, alguns Conselhos Estaduais e Municipais fizeram consultas a instâncias superiores a fim de obter respostas. Um desses pedidos de esclarecimentos foi elaborado pelo Conselho Estadual de Educação do Sergipe e enviado ao Conselho Nacional de Educação (CNE), que resultou no Parecer $n^{\circ} 18 / 2007^{65}$. Este é o único documento oficial que objetivou esclarecer dúvidas das Secretarias relativas à implantação da Lei 11.161/2005. As cinco questões apresentadas são referentes a questionamentos (em sua maioria, já apresentados aqui) relativos à carga horária, obrigatoriedade, formação dos alunos, entre outros.

É pertinente notar que o documento (BRASIL, 2008, p. 2) reconhece que o texto da Lei 11.161/2005 “apresenta-se com certos dispositivos que não primam pela clareza e pela sistemática, com elementos e determinologia inconsistentes e estranhos à legislação e Diretrizes Curriculares Nacionais". Assim, evidencia-se que o Ministério da Educação reconheceu que a Lei 11.161/2005 não era uma norma clara, travando um embate com o Poder Legislativo ao dar a entender que os legisladores desconheciam os termos da legislação educacional brasileira, bem como o funcionamento da instituição escolar.

\footnotetext{
${ }^{65} \mathrm{O}$ documento completo está disponível em: 〈http://portal.mec.gov.br/cne/arquivos/pdf/2007/pceb018 07.pdf >. Acesso em 10 ago. 2014.
} 
Exemplo disso é o Parecer (IBIDEM, p. 5, grifo meu) afirmar que os termos Centros de Ensino de Língua Estrangeira e Centro de Estudos de Língua Moderna são estranhos à Legislação educacional, atribuindo até mesmo um tom irônico ao dizer

\begin{abstract}
Daí a oportunidade de registrar nossa curiosidade sobre a origem destes termos e da concepção, ou melhor, da recepção pelos legisladores do País deste tipo de instituição no âmbito da "educação escolar" e da Educação Básica dos brasileiros. E, sobretudo, podemos aproveitar esta oportunidade para consignar nossa dúvida sobre a legalidade de elemento desta natureza, em caráter impositivo para a arquitetura institucional dos sistemas de ensino e dos órgãos executivos dos entes federados.
\end{abstract}

Assim, este documento atingiu diretamente os legisladores da "Lei do Espanhol", chegando a expressar sua dúvida no que tangia à legalidade dos termos da referida lei. Infelizmente, a textualidade da Lei 11.161/2005 e o fragmento acima do único documento oficial do MEC que visou esclarecer os sentidos da lei demonstram que a legislação educacional brasileira continua sendo implementada por legisladores que desconhecem as realidades existentes em nosso país. Portanto, a implantação de um novo idioma por meio de uma lei não basta, deve estar em concordância com as realidades existentes, sendo estas também, conhecidas pelos legisladores.

Logo, como demonstrou González (2009), na realidade o brasileiro tem leis que não são cumpridas bem como "belos discursos que não chegam à prática e vamos implantando atabalhoadamente e sem regras claras políticas linguísticas que nem sequer emanam claramente dos anseios e necessidades da nossa população e sim de outros interesses”.

\title{
2.4.4 As ações governamentais federais positivas ao ensino de Espanhol no Brasil
}

Apesar de a implantação da língua espanhola por meio da Lei 11.161/2005 ter desencadeado uma série de problemáticas para o ensino desta língua, é válido destacar de forma breve algumas ações do governo Federal que impactaram de forma positiva a implantação do Espanhol no Brasil:

Publicação das Orientações Curriculares para o Ensino Médio (2006): Sendo o Espanhol a única língua explicitamente designada como de oferta obrigatória no Brasil, o Ministério da Educação achou por bem dedicar um capítulo exclusivo às questões relacionadas ao ensino desse idioma. Segundo as próprias autoras do capítulo “Conhecimentos de Espanhol” (Isabel Gretel M. Eres Fernández e Neide Maia González), a 
sanção da Lei 11.161 esteve claramente associada a um gesto de política linguística. Por isso, no sentido de traçar rumos e nortear o ensino de Espanhol bem como até mesmo assumir um caráter "regulador", as Orientações Curriculares para o Ensino Médio (doravante OCENS) foram escritas não para trazer soluções, mas para dar diretrizes e sugestões. Cabe destacar que as autoras desejaram com a escrita deste capítulo que "a oferta do ensino da língua espanhola não ficasse atrelado estritamente a questões de mercado" (GONZÁLEZ, 2010, p. 27). Logo, é visível a riqueza de informações que este capítulo trouxe para o ensino de Espanhol, visto que em si buscou demonstrar que o ensino de Espanhol vai muito além de uma questão meramente política.

Inclusão do Espanhol no Programa Nacional do Livro Didático: As línguas estrangeiras modernas (Espanhol e Inglês) foram incluídas nos editais do Programa Nacional do Livro Didático - para o Ensino Fundamental (Edital PNLD 2011 e 2014) e Ensino Médio (Edital PNLD 2012), no qual as escolas públicas de todo país (sejam elas de esfera Federal, Estadual ou Municipal) poderiam aderir ao programa e receber coleções didáticas dessas duas LEs. Vale ressaltar que os livros de LE são consumíveis, isto é, pertencem ao aluno e não há necessidade de devolução. As coleções vieram acompanhadas de um CD de áudio e um Manual do professor.

Inclusão das línguas estrangeiras (Inglês e Espanhol) no Programa Nacional Biblioteca da Escola (Edital PNBE 2011 e 2014): Esse programa beneficia várias escolas com a distribuição de obras de caráter teórico-metodológico para os professores de Espanhol e de Inglês.

Inclusão das línguas estrangeiras (Inglês e Espanhol) no exame Nacional do Ensino Médio (doravante ENEM): Desde 2010 o Espanhol integra as disciplinas do ENEM, sendo assim, mais uma opção ao aluno no momento de ser avaliado. Percebe-se nesse ato o reconhecimento do Espanhol como um componente curricular, visto que é elencada juntamente com as outras disciplinas como forma de avaliação.

\subsection{5 "Del dicho al hecho hay un trecho": As realidades do ensino de Espanhol}

No final de 2009 e princípios de 2010 - prazo final para a implantação do Espanhol nas escolas públicas e privadas -, os meios de comunicação retrataram a situação da implantação do Espanhol no Brasil. Em um artigo publicado em 2009 titulado "Espanhol 
obrigatório nas escolas está longe de se tornar realidade ${ }^{66 "}$ se afirma que 2010 iniciaria sem que $75 \%$ das escolas brasileiras estivessem preparadas para oferecer o Espanhol. Naquele momento, das 25 mil escolas do país, de acordo com o Censo da Educação Básica de 2008, apenas 6.600 ofereciam a disciplina. Outros artigos coincidiram com tal afirmação, tais como: “Obrigatório em 2010, espanhol é ensinado hoje a só 15\% dos alunos" ("FOLHA UOL", 2009), "Lei do espanhol ficou no papel" ("VALOR ECONÔMICO”, 2010), e surpreendentemente, em 2013 ainda vemos notícias com o mesmo discurso: "O ensino de espanhol ainda é uma matéria pendente no Brasil" (“EL PAÍS”, 2013).

Infelizmente, como cada Secretaria de Educação Estadual e Municipal decidiu como proceder no que tangia à implementação, o que se percebe é que ainda hoje há um grande desrespeito; descaso, descompromisso e omissão ao cumprimento da lei, tendo em vista que não se especificou nenhuma punição aos estados que não efetivassem a implementação.

Atualmente, após quase dez anos de sanção da Lei 11.161/2005 e quatro anos após sua obrigatoriedade, ainda há muitos estados e municípios brasileiros nos quais há escolas que oferecem o Espanhol, e outras não, bem como estados que oferecem o Espanhol de maneira extracurricular (como no Paraná e em São Paulo, por exemplo, nos quais o ensino de Espanhol é realizado em Centros de línguas, fora da grade curricular). Fernández (2014, p. 11) elucida que ainda que a existência de centros de línguas seja melhor que sua ausência, “é necessário que se intensifiquem ações para que a LDB (Lei 9394/96) seja amplamente cumprida, ou seja, que se ofereçam dois idiomas no Ensino Médio e uma no Ensino Fundamental". Portanto, de que adianta cumprir uma norma e descumprir outra? Por que situar à margem a única língua de oferta obrigatória no Brasil que possibilita inúmeras oportunidades aos seus aprendizes, tratando-a como um peso, um problema a ser resolvido, ou algo do qual as escolas tenham que se "livrar"?

Além desses fatores, as condições nas quais o Espanhol foi implantado em solo brasileiro não favorecem a qualidade deste ensino. Notam-se inúmeras incoerências administrativas tais como péssimo estado estrutural e físico; falta de material didático, má formação de docentes, carga horária insuficiente, salas de aulas lotadas, falta de investimento público, assim como muitos outros fatores que contribuem para a desvalorização da disciplina no imaginário da comunidade escolar como um todo.

\footnotetext{
${ }^{66}$ Disponível em: <http://educacao.ig.com.br/us/2009/11/14/espanhol+obrigatorio+nas+escolas+esta+longe+de+se+tornar+realida de+9088957.html>. Acesso em 12 de setembro de 2013.
} 
Inserir uma disciplina no currículo escolar não é somente ofertá-la, mas trabalhar para que a qualidade de seu ensino seja coerente com as propostas educacionais. Como afirmaram Maciel e Oliveira (2011, p. 4) "não basta simplesmente assinar uma lei e não dar subsídios para sua prática efetiva".

Nesse pensamento, GONZÁLEZ (2009) afirma que "há uma enorme distância entre o dizer e o fazer: del dicho al hecho hay un trecho, e tememos ouvir as velhas expressões: 'a lei não pegou', 'a lei não vingou', 'a lei, ora a lei!' no lugar de um belo e forte 'dito e feito'”. Infelizmente todas essas afirmações foram feitas... E continuam ecoando pelas escolas de nosso país.

Entretanto, ainda que a Lei 11.161/2005 e sua atual aplicação (e falta dela) apresentem inúmeras falhas, desvalorizando o Espanhol em diversas instâncias, a mesma abriu espaço para a reflexão, demonstrando através de tantos descompassos o quão necessário é repensar o papel da língua espanhola na escola, bem como lutar pela não acomodação dos docentes desta disciplina, pois estes tem papel fundamental nesta implantação. Como elucidou Leffa (2005, p. 214), “a militância política só existe quando não estamos satisfeitos com alguma coisa e queremos provocar mudança”. Logo, existe a grande necessidade de o professor enxergar-se como professor e político, pois nós, professores, "sairemos perdendo sempre que passarmos à outra pessoa a responsabilidade de defender nossos interesses" (IBIDEM, p. 208). Portanto, diante de toda esta realidade, “é assim que queremos maltratar a língua cuja oferta estamos impondo?" (GONZÁLEZ, 2009).

Desse modo, tendo em vista esta lei vigorando com tantas irregularidades e lacunas, fazem-se necessárias descrições reais acompanhadas de relatos de como a Lei 11.161/2005 vem sendo implantada nas escolas públicas brasileiras, bem como o levantamento das realidades existentes: realidades de sucesso, assim como realidades que clamam por intervenções e melhorias. Para que a implantação do Espanhol não seja uma "implantação de fachada", nós, brasileiros, privados do ensino de Espanhol por tanto tempo, precisamos compreender, e entender que, de fato, "a lei é uma conquista de todos nós" (ÁTILA LIRA, 2005).

Neste capítulo apresentei a construção teórica que serviu de sustentação para esta investigação. No capítulo seguinte apresentarei os procedimentos metodológicos que nortearam esta pesquisa. 


\title{
CAPÍTULO 3 \\ REFERENCIAL METODOLÓGICO
}

\author{
"O mundo, como universo organizado, \\ não é um fato empírico como pedras, \\ cadeiras e sapatos. Trata-se de uma construção \\ empreendida pelo sujeito." \\ (RUBEM ALVES, 1980, p. 84)
}

Este capítulo pretende apresentar o percurso metodológico desta pesquisa. Esta investigação é de caráter qualitativo-interpretativista. Com base nisso, julguei importante fazer uma explanação acerca da pesquisa qualitativa e seus desdobramentos, tais como seu surgimento, sua importância, suas características e seu caráter interpretativo. Também tratarei sobre o uso da pesquisa qualitativa na análise de políticas sociais, uma vez que este estudo aborda uma política pública, educacional linguística.

Cabe destacar que o fato desta pesquisa assumir um caráter qualitativo não excluiu a utilização de alguns dados quantitativos, pois, concordando com o pensamento de Flick (2009a, p. 43), entendo que "um estudo poderá incluir abordagens qualitativas e quantitativas em diferentes fases do processo de pesquisa".

Tendo em vista as particularidades e objetivos deste estudo, esta investigação constitui-se como uma pesquisa de método misto (YIN, 2010), pois compreende um estudo de caso - mais especificamente, um estudo de casos múltiplos - acrescido de uma análise documental realizada à luz da Hermenêutica.

Após essas conceituações, apresentarei os instrumentos de coleta de dados: notas de campo da pesquisadora; entrevistas e a análise das narrativas nelas apresentadas, questionários com perguntas abertas e fechadas e observação participante. Por fim, explanarei a Triangulação como método de análise de dados; o cenário onde a pesquisa foi realizada, seus participantes, as questões éticas envolvidas e o período da coleta de dados.

\subsection{A pesquisa qualitativa nas Ciências Sociais}

Em concordância com Denzin e Lincoln (2006, p. 17), percebo que qualquer definição de pesquisa qualitativa deve se desenvolver dentro de seu complexo contexto histórico. Tal afirmação se baseia no fato de que ao longo de sua trajetória nas ciências sociais, a pesquisa qualitativa atravessou diversos momentos: tensões, tais como menosprezo e rejeição pela 
comunidade científica vigente, bem como ápices, despertando crescente interesse e curiosidade, chegando a atravessar disciplinas, campos e temas. Com uma trajetória de altos e baixos, a pesquisa qualitativa passou por transformações que acarretaram mudanças e novas perspectivas, trazendo-a até seu momento atual.

Na visão de Flick (2009a, p. 36), há uma heterogeneidade no tocante a definições de pesquisa qualitativa. Essas definições costumam ser resumidas, acarretando a unificação de uma questão que foi e continua sendo diversificada. Para Denzin e Lincoln (2006, p. 21), essa multiplicidade de significados e empregos da pesquisa qualitativa dificulta o pesquisador a chegar a qualquer definição essencial da mesma. Sendo assim, na tentativa de definir a pesquisa qualitativa baseada em seu contexto histórico-social, em um primeiro momento procurarei de forma breve situar historicamente o surgimento da pesquisa qualitativa, para, em seguida, discorrer sobre suas características essenciais ${ }^{67}$.

\subsubsection{A necessidade de um paradigma qualitativo}

Segundo Ludke e André (2013, p. 3), o estudo dos fenômenos educacionais está situado entre as ciências humanas e sociais, tendo sofrido influência das evoluções ocorridas nessas ciências. Dessa forma, por um longo período, as pesquisas em educação buscaram seguir os modelos utilizados nas ciências físicas e naturais. Esses modelos baseavam-se no que é chamado de "paradigma Positivista", ou "Positivismo", fundamentado em tradições explicativas e cientificistas.

O Positivismo estruturou-se no século XIX a partir de Augusto Comte, e como elucida Bortoni Ricardo (2009, p. 10), começou a ser utilizado nas ciências exatas e posteriormente, nas ciências sociais. A autora afirma que o Positivismo influenciou toda a atividade científica, cultural e até mesmo o modo de vida daquela época. Bortoni Ricardo (IBIDEM, p.14) também relata que na visão positivista, "a realidade é aprendida por meio da observação empírica. As descobertas se dão pela via da indução, que é o processo de chegar a regras e leis gerais pela observação das regularidades".

Foi neste contexto que, derivando do pensamento positivista, estabeleceu-se com êxito a pesquisa quantitativa, ou "pesquisa experimental" (CHIZZOTTI, 2011, p. 27). Durante

\footnotetext{
${ }^{67}$ É válido ressaltar que o objetivo não é fazer uma descrição exaustiva, porém, propiciar ao leitor a
} possibilidade de melhor compreender o surgimento da pesquisa qualitativa, sua importância e suas implicações. 
muito tempo a pesquisa quantitativa obteve a primazia na investigação científica, levando, inclusive, ao pensamento de que todo conhecimento considerado legítimo deveria ter sua fundamentação na pesquisa científica. Este tipo de pesquisa buscou "documentar e analisar a frequência e a distribuição dos fenômenos sociais na população" (FLICK, 2009a, p.22). Sendo assim, a pesquisa quantitativa procurou mensurar e comprovar a frequência de incidências, constituindo-se de critérios rígidos de dados e de suas análises, fazendo uso de estatísticas e de levantamentos. Para os pesquisadores quantitativos o pesquisador deveria buscar a neutralidade e permanecer distante de seu objeto de estudo, para garantir, assim, uma "perfeita objetividade" (LUDKE e ANDRÉ, 2013, p. 5, grifo meu).

Ainda que a pesquisa quantitativa estivesse consolidada no âmbito investigativo, em determinado momento passou a não "dar conta" das mudanças sociais, e consequentemente, dos novos interesses, contextos e perspectivas dos investigadores sociais. Uma grande revolução estava para acontecer. Flick (op.cit., p. 21, grifo meu) explica este momento, ao discorrer acerca das mudanças que teriam que ser tomadas pelos investigadores positivistas, ao perceberem que se tratava de "situações tão novas para eles que suas metodologias dedutivas tradicionais [...] agora fracassam devido à diferenciação de objetos”. Assim, ao invés de partir de teorias, seria necessária a utilização de conceitos "sensibilizantes", bem como o uso de estratégias indutivas.

Logo, como uma reação ao paradigma positivista (DE GRANDE, 2011, p.12), surgiu a pesquisa qualitativa, como resposta às necessidades que emanavam no âmbito investigativo. A pesquisa qualitativa não teve uma trajetória linear após seu surgimento, pelo contrário, atravessou diversos momentos de abandonos e ápices, "tendo retornado com força no final dos anos 1960, principalmente na metade dos anos 1970” (DESLAURIERS e KÉRISIT, 2008, p. 127), e permanecendo até os dias atuais em várias disciplinas, pois se consolidou como um “campo de investigação". (DENZIN e LINCOLN, 2006, p. 16).

\subsubsection{A pesquisa qualitativa: importância e implicações}

A pesquisa qualitativa renovou os olhares sobre os problemas sociais, propondo novas maneiras de produzir e intervir (GROULX, 2008). Enquanto os estudos puramente quantitativos contemplavam casos e participantes em grande escala, a pesquisa qualitativa abordará um menor número de casos, para analisá-los com riqueza de detalhes. Entretanto, ainda poderá utilizar-se de alguns olhares quantitativos, visto que em determinados 
momentos, esses olhares poderão ser complementares em um estudo (FLICK, 2009a, p. 43), como poderá ser observado nesta investigação.

Ademais de concentrar-se em casos específicos, outras razões que levaram esta pesquisa ao estudo qualitativo é que este "é o que se desenvolve numa situação natural, é rico em dados descritivos, tem um plano aberto e flexível e focaliza a realidade de forma complexa e contextualizada”. (LUDKE e ANDRÉ, 2013, p. 20, grifo meu). Dessa maneira, a pesquisa qualitativa também é chamada de pesquisa naturalística (CHIZZOTTI, 2011, p. 30), pois os problemas abordados são estudados nos ambientes nos quais ocorrem, sem manipulações do pesquisador. Em cada caso estudado, o pesquisador encontrará vidas em “contextos históricos definidos" (IBIDEM, p. 14).

Outro fator que me conduziu à pesquisa qualitativa diz respeito à neutralidade. Para os pesquisadores qualitativos, "a neutralidade não existe, e a objetividade é relativa, diferentemente do que ocorre no positivismo" (MARTINS, 2004, p. 292). Na pesquisa qualitativa não há como observar e analisar o mundo independentemente de significados e práticas sociais, não há necessidade de distanciamento total entre pesquisador e objeto, visto que "o envolvimento emocional do pesquisador em seu objeto [...] constituiria o ponto de partida" (DESLAURIERS e KÉRISIT, 2008, p. 133). Logo, além de valorizar a proximidade entre pesquisador e objeto, a pesquisa qualitativa busca "ver o indivíduo não mais como um objeto, mas como sujeito do conhecimento e da história”. (MARTINS, op. cit., p. 298).

\subsubsection{A pesquisa qualitativo-interpretativista}

Além de qualitativo, esse estudo assume um caráter qualitativo-interpretativista. De acordo com Erickson (1986), a pesquisa qualitativo-interpretativista abarca uma abordagem na qual o pesquisador, para coletar seus dados, parte de observações do fenômeno estudado para analisá-los e interpretá-los posteriormente, sem a necessidade de partir da aplicação de um experimento controlado ou testar hipóteses.

Em conformidade com Moita Lopes (1994), percebo que não é possível para o pesquisador interpretativista padronizar os fatos do mundo social e reduzir a realidade a somente uma causa, pois tais ações são consideradas distorções da realidade criada pela investigação científica. A pesquisa qualitativa abarca várias vozes, vários métodos e vários instrumentos, não sendo possível analisar o mundo apenas de um ponto de vista. 


\subsubsection{A pesquisa qualitativa e as políticas sociais}

Além de identificar uma visão mais apurada da realidade, a pesquisa qualitativa revela descompassos e reconceitua problemas sociais, como se propõe a presente investigação. Além disso, torna o pesquisador um modificador de "políticas sociais em importantes aspectos" (DENZIN e LINCOLN, 2006, p. 37). Sendo assim, a pesquisa qualitativa também tem seu caráter político, e pode levar a transformações sociais através das múltiplas vozes que o pesquisador qualitativo adquire.

Majchrzak (1984 apud DESLAURIERS e KÉRISIT, 2008, p.132), afirma que há vantagens em utilizar-se da pesquisa qualitativa na análise de políticas sociais. Contudo, explica que várias particularidades a diferenciam dos outros tipos de pesquisa. Refletindo sobre estas particularidades, enxergo que elas se aplicam ao presente estudo e seus objetivos, dentre as quais, destacarei três:

a) Possuir um objeto multidimensional: O ensino de Espanhol em escolas públicas, bem como a implantação da lei 11.161 são fatores que possuem várias faces e dimensões, uma vez que abarcam inúmeras realidades.

b) Se reportar ao futuro, bem como ao passado: No presente estudo, fez-se necessária a análise do ensino de Espanhol e as tentativas de implantação desta língua no Brasil em épocas passadas, bem como a explanação de expectativas de mudanças para o futuro.

c) Ser sensivel aos utilizadores dos resultados: Segundo Martins (2004, p. 299), ao escrever, o pesquisador deve preocupar-se em que seu discurso alcance aqueles que dele necessitam. Desse modo, enxergo que a comunidade escolar como um todo (professores, alunos, pais, etc.) necessita de estudos que proponham melhorias para o ensino de Espanhol em escolas públicas.

\subsection{O estudo de caso acrescido da análise documental: uma pesquisa de método misto}

Ao refletir sobre as particularidades e os objetivos propostos nesta investigação, eu e minha orientadora optamos por um estudo de caso acrescido de uma análise documental. Esta decisão se justifica em função das questões iniciais as quais esta pesquisa se propôs investigar, que incluem um evento contemporâneo situado em um contexto específico (a implantação da Lei 11.161/2005 em escolas públicas), e por isso, a escolha pelo estudo de caso; bem como a melhor compreensão da legislação acerca do assunto em questão. Esta 
legislação abarca os documentos oficiais envolvidos neste longo processo de implantação da língua espanhola no Brasil, que, nesta pesquisa, necessitaram de um tratamento interpretativo. Trata-se, portanto, da necessidade de utilizar a análise documental como método.

Segundo Yin (2010), os estudos nos quais os pesquisadores utilizam mais de um método são denominados pesquisas de métodos mistos. Para o autor, uma pesquisa que utiliza métodos mistos pode permitir que os pesquisadores "abordem questões de pesquisa mais complicadas e coletem uma série mais rica e mais forte de evidência do que poderiam obter por qualquer método único isolado" (IBIDEM, p. 85, grifo meu). Inclusive, segundo o autor, o pesquisador deveria levar em consideração a possibilidade de combinar o estudo de caso com outros métodos.

Dessa forma, esta pesquisa constitui-se como uma pesquisa de métodos mistos, pois utiliza dois métodos simultaneamente, visando o alcance dos objetivos desta investigação, assim como uma maior variedade e riqueza de dados, como elucida André (2005, p.53, grifo meu), ao afirmar que "documentos são muito úteis nos estudos de caso porque complementam informações obtidas por outras fontes e fornecem base para triangulação dos dados", como pretende esta investigação. Além disso, a análise documental é um "meio de reforçar o entendimento em estudos de caso pela capacidade de situar os relatos contemporâneos em um contexto histórico" (MAY, 2004, p. 205). A seguir, cada um desses métodos, em conjunto com suas implicações e características, será explanado de forma delineada.

\subsubsection{Estudo de caso: visibilidade dos problemas da prática educacional}

Considerei o estudo de caso adequado para esta pesquisa, pois, as inquietações que resultaram nas questões e objetivos apresentados neste estudo surgiram da necessidade de compreender um fenômeno social complexo, situado em um contexto específico e contemporâneo: a implantação da Lei 11.161/2005 em escolas públicas do DF, mais especificamente, nas RAs Taguatinga e Paranoá.

Chizzotti (2011, p. 135, grifo meu) define com propriedade minha opção pelo estudo de caso, quando afirma que este método de pesquisa visa "alcançar um conhecimento mais amplo sobre esse objeto, dissipando as dúvidas, esclarecendo questões pertinentes, e, sobretudo, instruindo ações posteriores". De fato, esta investigação pretende conhecer mais de perto a realidade por trás da implantação da referida lei, esclarecendo questionamentos que não se calam, bem como revelando descompassos, com o intuito de trazer propostas de ações para o futuro. 
Concordo plenamente com Stake (1983, p. 6), quando, ao falar de sua visão sobre pesquisa educacional e sua utilidade, assegura que a pesquisa educacional deve estar a serviço da educação, e proporcionar "melhor compreensão de seus problemas práticos". Esta característica é também vista por André (2005, p. 35, grifo meu), ao discorrer que

\begin{abstract}
Outra qualidade usualmente atribuída ao estudo de caso é o seu potencial de contribuição aos problemas da prática educacional. Focalizando uma instância em particular e iluminando suas múltiplas dimensões assim como seu movimento natural, os estudos de caso podem fornecer informações valiosas para medidas de natureza prática e para decisões políticas.
\end{abstract}

Desse modo, o estudo de caso se torna viável nesta investigação, porquanto, além de observar e analisar instâncias particulares com profundidade, provê informações para medidas práticas e políticas, como as que esta pesquisa pretende sugerir, visto que este estudo de caso se propõe obter uma melhor compreensão da problemática do ensino de Espanhol em escolas públicas após sua implantação aos currículos da educação básica brasileira.

O estudo de caso tem sido utilizado há muito tempo em várias áreas do conhecimento, tais como a antropologia; sociologia, direito, administração, entre outras. Na área da educação, especificamente, começou a ser utilizado nas décadas de 1960 e 1970, quando foi aparecendo nos manuais de metodologia de pesquisa (IBIDEM, p. 14). Durante muito tempo foi visto como um procedimento pré-experimental e pouco rigoroso. Entretanto, atualmente é considerado o delineamento mais adequado para se estudar um fenômeno contemporâneo dentro de seu contexto real. (YIN, 2010). Sendo assim, trata-se de um estudo "profundo e exaustivo de um ou poucos objetos, de maneira que permita seu amplo e detalhado conhecimento." (GIL, 2010, p. 37)

Além de estudar um ou mais casos específicos de forma profunda, o estudo de caso necessita da utilização de múltiplas técnicas de coleta de dados, justamente para garantir a profundidade necessária e conferir maior credibilidade ao estudo e seus resultados (IBIDEM, p. 119). Como será demonstrado adiante, esta investigação fará uso de diversos instrumentos, acarretando uma "variedade de dados, coletados em diferentes momentos, em situações variadas e provenientes de diferentes informantes." (ANDRÉ, 1984, p. 52)

Por fim, o estudo de caso não visa generalizações, no entanto, ainda pode evidenciar realidades compartilhadas, como afirma Chizzoti (2011, p. 138, grifo meu) ao dizer que "um caso pode revelar realidades universais, porque, guardadas as peculiaridades, nenhum caso é um fato isolado, independente das relações sociais onde ocorre". 


\subsubsection{O estudo de casos múltiplos (YIN, 2010), ou coletivo (STAKE, 1995)}

Na visão de Yin (2010, p. 70), ao se projetar estudos de caso, faz-se necessária a distinção entre os projetos de caso único e os de casos múltiplos. A nomenclatura de cada caso traz em si sua conceituação: os projetos de caso único abordam somente uma unidade de análise, ou seja, um caso, pessoa, ou evento. Entretanto, “o mesmo estudo pode conter mais que um único caso" (IBIDEM, p. 77). Quando isso ocorrer, trata-se de um projeto de casos múltiplos, ou, como definiu Stake (1995), um estudo de caso coletivo. Este tipo de estudo de caso "não se concentra em um só caso, mas em vários, como por exemplo, em várias escolas, ou vários professores, com finalidade intrínseca ou instrumental” (ANDRÉ, 2005, p. 20).

Com base nisso, o estudo de caso realizado nesta pesquisa compreende um estudo de casos múltiplos, pois contemplará a implantação da Lei 11.161/2005 em duas RAs do DF: Taguatinga e Paranoá, analisando dados gerais acerca de cada regional de ensino e dados específicos de uma escola de cada RA, como serão evidenciadas mais adiante, no cenário desta investigação.

Sobre os estudos de casos múltiplos, Yin (2010, p. 85), aconselha ao pesquisador que, quando este tiver opção, escolha pelo estudo de casos múltiplos ao invés do estudo de caso único, ainda que faça um estudo de caso de somente "dois casos" (como o estudo desta investigação). O autor baseia esta afirmação no pensamento de que os estudos de casos múltiplos são considerados mais vigorosos e robustos, pois apresentam mais de uma realidade, assim como conclusões mais ricas provenientes dos dois casos estudados. Além disso, ao utilizar-se do estudo de casos múltiplos, as chances de realizar um bom estudo de caso seriam maiores (YIN, loc.cit).

\subsection{A análise documental: o olhar além do texto}

"Imprescindível em qualquer estudo de caso" (GIL, 2010, p. 121), a análise documental tem sido utilizada em "praticamente todas as ciências sociais" (IBIDEM, p.30). Pode ser utilizada juntamente com outros métodos (como nesta pesquisa), ou como um "método autônomo" (FLICK, 2009a, p. 231). Basicamente, consiste em analisar documentos que sirvam como fonte de informação, reconstruir informações factuais tais como um passado; evento, fato, decisão, história, etc, como também compreender intenções e interesses presentes na documentação analisada. 
Segundo May (2004, p. 205), há uma grande variedade de fontes documentais à disposição para a pesquisa social. Contudo, o conceito de documento é muito amplo, visto que "este pode ser constituído por qualquer objeto capaz de comprovar algum fato ou acontecimento" (GIL, 2010, p. 31). Sendo assim, “tudo que é vestígio do passado, tudo o que serve de testemunho, é considerado como documento...” (CELLARD, 2008, p. 296, grifo meu). Portanto, ao contrário do que muitos pensam, documentos não se restringem ao que é tão somente escrito, tendo em vista que o pesquisador "pode valer-se de documentos contidos em fotografias, filmes, gravações sonoras [...], CD-ROM, DVDs, etc” (GIL, op. cit., p. 66).

No entanto, por excelência, a documentação mais utilizada em ciência tem sido a escrita. Essa documentação escrita compreende desde legislação; "normas, pareceres, cartas, memorandos, diários pessoais, autobiografias, jornais, revistas, discursos, roteiros de programa de rádio e televisão até livros, estatísticas e arquivos escolares" (LUDKE e ANDRÉ, 2013, p. 45). No que tange à documentação utilizada nesta pesquisa (para fins de análise), foram os documentos oficiais relativos à implantação do Espanhol no Brasil os escolhidos para dar sustentação às questões deste estudo; bem como às observações, aos questionamentos, aos descompassos, às confirmações e às conclusões encontradas, pois, "os documentos constituem também uma fonte poderosa de onde podem ser retiradas evidencias que fundamentam afirmações e declarações do pesquisador” (IBIDEM, p.45, grifo meu).

Acerca da conceituação de documentos oficiais, em concordância com Marconi e Lakatos (2009, p. 51), entendo que documentos oficiais "constituem geralmente a fonte mais fidedigna de dados. Podem dizer respeito a atos individuais, ou, ao contrário, atos da vida política, de alcance municipal, estadual ou nacional". Contudo, como afirmam as autoras, o pesquisador deve estar atento ao fato de não exercer controle sobre o modo como os documentos foram criados, devendo assim, interpretar o material selecionado para que este se torne utilizável.

Para Flick (2009a, p. 232), os documentos não são somente uma mera representação da realidade, mas foram produzidos visando a algum objetivo e para algum tipo de uso, ainda que estes, em um primeiro momento, não fiquem claramente definidos. Dessa forma, utilizando-se da análise documental, cabe ao pesquisador compreender o que foi propagado ou suprimido acerca do assunto abordado no documento. Em concordância com May (2004, p. 213), acredito que há muitos significados "embutidos" nos documentos, visto que muitas vezes, o documento "dá voz àqueles traços que, em si mesmos, com frequência, são não 
verbais ou que dizem em silêncio algo diferente do que dizem de fato" (FOCAULT, 1989, p.7, grifo meu).

Assim, é preciso analisar e buscar compreender o contexto no qual o documento foi criado, para identificar as intenções verdadeiras e reais objetivos de sua criação. Para Cellard (2008, p. 299) o exame do contexto social global é primordial na análise documental, pois o contexto dará pistas acerca dos intuitos e finalidades legítimas do documento em questão. Logo, "é necessário um estudo do momento político, interno e externo, em que os documentos foram elaborados, para compensar certos desvios" (MARCONI e LAKATOS, 2009, p. 55). Nesse pensamento, Chizzotti (2011, p.117) relembra que o pesquisador deve ir além do texto, quando afirma que é necessário

[...] não se restringir ao que está expresso nas parcelas do texto, mas fazer uma leitura do contexto e das circunstancias em que a mensagem foi feita, e autorizar uma leitura subjacente ao texto, aquilo que está além do que é manifesto, e, deliberada ou inconscientemente, é preterido: as omissões, as ignorâncias consentidas $[\ldots]$

Flick (2009a) apresenta algumas perguntas que o pesquisador precisa ter em mente ao utilizar-se da análise documental. Estas perguntas fornecerão ao pesquisador uma ampla quantidade de tópicos de análise:

1. Quem produziu este documento?

2. Com que objetivo?

3. Para quem?

4. Quais eram as intenções pessoais ou institucionais com a produção desse documento ou dessa espécie de documento?

5. O que foi omitido na produção do registro, por quem e por quê?

6. Quais são as circunstâncias sociais que podem ter influenciado na produção do registro?

Desse modo, é essencial que o pesquisador mantenha um olhar crítico, bem como uma reflexão contínua, para que suas interpretações não sejam antecipadas, errôneas ou imprecisas, pois a análise documental trata-se de um método que demanda grande concentração, pois é possível dizer muitas coisas em apenas poucas linhas (Cellard, op.cit., p. 314). Sendo assim, qualquer descuido poderá fazer com que o pesquisador perca de vista ou deixe passar significados importantes no documento, que não seriam visíveis em uma leitura inicial. 


\subsubsection{O auxílio do olhar interpretativo da Hermenêutica}

Atualmente, no campo investigativo há uma amplitude de pressupostos filosóficos; métodos, técnicas e disciplinas que se propõem a auxiliar o pesquisador a analisar um documento e extrair dele seus significados. Esses métodos são fundamentados em diversas teorias linguísticas, tais como a semiótica; o estruturalismo, o pós-estruturalismo, o interacionismo, a análise da conversação, a análise do discurso, a hermenêutica, entre outras, pois, de fato, "a história desenvolveu muitas teorias e técnicas de análise e interpretação de textos documentais históricos" (CHIZZOTTI, 2011, p. 114). Essas teorias estão à disposição do pesquisador para que este, fundamentado no que elas teorizam, possa melhor compreender e analisar os documentos que compõem a sua pesquisa.

Neste tipo de análise, o pesquisador é visto como um intérprete, ou como um exegeta envolvido em uma análise crítica: "as filosofias interpretativistas em geral, definem o papel do intérprete no modelo do exegeta, ou seja, do indivíduo engajado em uma análise crítica ou explicação de um texto empregando o método do círculo hermenêutico" (SCHWANDT, 2006, p. 198).

Tendo em vista que este estudo abarcou uma análise documental, optei recorrer ao auxílio da Hermenêutica para interpretar os documentos desta pesquisa. Esta decisão se justifica no fato de que a hermenêutica, considerada a arte de interpretar leis e o sentido das palavras, constitui-se como uma rica forma de representar a noção de compreensão interpretativa. Percebo a compreensão hermenêutica como um desvelamento interpretativo e um paradigma reflexivo, que me proporciona a compreensão que um método puramente analítico não me proporcionaria.

Historicamente, a hermenêutica teve sua origem no final do século XIX e início do século XX, como uma reação ao dominante positivismo, tratado brevemente no início deste capítulo. O cerne da disputa consistia na ideia de que as ciências humanas possuíam diferenças precisas no tocante à finalidade e à natureza em relação às ciências naturais, porquanto, as ciências humanas buscavam compreender as ações humanas, ao passo em que as ciências naturais buscavam explicações causais.

Com base nisso, a Hermenêutica, como um pressuposto que visa compreender a ação humana, me parece viável neste estudo, uma vez que abarca a compreensão do todo, e não somente do que é considerado “objetivo". É necessário que se reflita acerca do contexto, visto que a hermenêutica enfatiza que, para que se entenda uma parte, ou seja, "(uma frase, um enunciado ou um ato específicos), o investigador deve entender o todo (o complexo de 
intenções, crenças e desejos ou o texto, o contexto institucional, a prática, a forma de vida, o jogo de linguagem, etc.)" (IBIDEM, p.197, grifo meu).

\subsection{Instrumentos de coleta de dados}

Visando assegurar a validade dos dados obtidos, garantir a profundidade e dar credibilidade a esta pesquisa e seus resultados, este estudo utilizou diversos instrumentos para a coleta de dados. Uma das principais características dos estudos de caso é a necessidade de instrumentos variados na coleta de dados, pois estes possuem a capacidade de líder com uma grande variedade de evidencias. No mesmo pensamento, Gil (2010, p. 119), afirma que "os estudos de caso executados com rigor requerem a utilização de fontes documentais, entrevistas e observações". Com base nisso, a pesquisa de campo ${ }^{68}$ realizada para coletar os dados desta investigação foi realizada em dois momentos:

1) Coleta de dados gerais: Em um primeiro momento, foram coletados dados gerais nas escolas públicas de Ensino Médio das duas RAs abordadas nesta investigação, com o intuito de traçar o panorama do ensino de Espanhol no nível de DF. Esses dados gerais foram obtidos através da própria pesquisa de campo juntamente com notas de campo da pesquisadora, um questionário e uma entrevista semi-estruturada aplicada aos docentes de Espanhol das escolas.

2) Coleta de dados específicos: A coleta de dados específicos utilizou os demais instrumentos desta pesquisa: entrevistas livres e a análise das narrativas nelas apresentadas; questionário com perguntas abertas e fechadas, observação participante, bem como, notas de campo. Este segundo momento de coleta de dados foi realizado nas duas escolas escolhidas para a realização desta pesquisa, mais especificamente, a análise de duas turmas de $3^{\circ}$ ano do Ensino Médio (uma de cada escola).

De maneira breve, a seguir discorrerei sobre cada um dos instrumentos de coleta de dados aqui elencados.

\subsubsection{Notas de campo}

As notas de campo, uma das formas mais usuais de registro, são essenciais para o desenvolvimento de pesquisas de cunho qualitativo, e podem ser obtidas "mediante

\footnotetext{
${ }^{68}$ Em concordância com Chizzotti (2011, p. 30), compreendo pesquisa de campo como "o local físico e social onde os dados foram coletados $[\ldots]$ "..
} 
observação ou entrevista" (GIL, 2010, p. 130). De maneira geral, são provenientes de observações diárias da pesquisa de campo como um todo, auxiliando o processo da análise de dados, realizado posteriormente.

Ainda não há um consenso no tocante à definição de notas de campo. Dessa forma, compreendo notas de campo como minhas impressões sobre as realidades que observei; episódios que vi, atos, fatos, sutilezas, pessoas com as quais conversei, bem como relatos informais que se mostraram dados relevantes para a pesquisa. Pensamentos, ideias, lembretes e até mesmo divagações. Essas notas também contêm questionamentos, ansiedades e conquistas, ao passo em que podem abarcar anseios, medos e frustrações.

Para Rosa e Arnoldi (2006, p. 59), o ato de tomar notas é muito útil também nos momentos de descontração, pois muitas vezes os participantes da pesquisa deixam "escapar" alguns dados. Neste momento, cabe ao pesquisador lançar mão de instantâneas anotações, que serão muito úteis posteriormente.

Cabe destacar que as notas de campo não devem ser adiadas, visto que a memória humana por vezes prega peças e chega a falhar em momentos importantes. Logo, devem ser anotadas de imediato, com o máximo de descrição possível.

\subsubsection{Entrevistas e análise de narrativas}

Considerada um dos instrumentos mais utilizados nas ciências sociais, a entrevista na pesquisa qualitativa busca considerar o ponto de vista dos atores sociais para compreender e interpretar suas realidades (POUPART, 2008, p. 216).

De acordo com Rosa e Arnoldi (op. cit., p. 29), a entrevista pode ser classificada em três tipos, de acordo com a estruturação e o roteiro de perguntas utilizadas:

a) Entrevista Estruturada - Este tipo de entrevista provém de um roteiro formal com uma sequencia padrão e uma linguagem fechada, visando à obtenção de respostas concisas, objetivas e diretas. Geralmente, os dados provenientes deste tipo de entrevistas são analisados à luz de um olhar quantitativo.

b) Entrevista semi-estruturada - Esta modalidade de entrevista requer também um roteiro de tópicos específicos, entretanto, "as questões seguem em formulação flexível, e a sequência e as minúcias ficam por conta do discurso dos sujeitos e da dinâmica que acontece naturalmente" (IBIDEM, p. 31). Sendo assim, trata-se de uma entrevista com 
maior flexibilidade, que abarcará a possibilidade de maior participação do entrevistador e do participante discorrer de maneira mais subjetiva e profunda acerca dos temas apresentados.

c) Entrevista Livre - Também chamada de Relato Oral, esta entrevista consiste em um relato do participante no qual praticamente não há intervenções do pesquisador.

Nos dados gerais esta investigação utilizou entrevistas semi-estruturadas realizadas com os docentes de língua espanhola das escolas pesquisadas nas duas RAs. Optei pela entrevista semi-estruturada, pois, corroborando com Ludke e André (2013, p. 40), esta se “desenrola a partir de um esquema básico, porém não aplicado rigidamente, permitindo que o entrevistador faça as necessárias adaptações". Nesse pensamento, a entrevista semiestruturada disponibiliza ao pesquisador a oportunidade de maior participação e intervenção nas falas do participante, possibilitando maior dialogismo entre entrevistador e entrevistado.

Já nos dados específicos optei pela "entrevista livre" aplicada às duas professoras das turmas analisadas, uma vez que meu objetivo com essas entrevistas foi tão somente ouvir e conhecer as reflexões das professoras acerca de suas práticas diárias.

Dentro das entrevistas, esta investigação também contará com a análise das narrativas nelas apresentadas. Segundo Flick (2009a, p. 307), as narrativas são coletadas na entrevista com o objetivo de "reconstruir processos biográficos". Logo, reconstroem eventos e histórias com riqueza de detalhes.

Refletindo sobre os benefícios de utilizar a análise de narrativas na pesquisa qualitativa, concluo que as narrativas:

a) Reconstroem eventos do passado (distante ou recente) do ponto de vista do participante - O participante é visto como uma figura central para a compreensão de determinada problemática de pesquisa. Portanto, como um sujeito inserido no contexto histórico-social de interesse do pesquisador, este participante retratará um passado como alguém que esteve intimamente inserido no acontecimento/evento pesquisado. Nesta pesquisa, por exemplo, as narrativas foram feitas por docentes que vivenciaram o início da implantação do Espanhol em escolas públicas, assim como o andamento do processo.

b) Incluem construções sociais e subjetivas - O participante reconstruirá processos sociais nos quais esteve inserido, bem como suas impressões pessoais acerca deles, e 
também possibilitará ao pesquisador os dados subjetivos sobre o acontecimento/evento pesquisado: suas visões; opiniões, questionamentos, discordâncias, aceitações, preconceitos, crenças, etc.

\subsubsection{Questionário com perguntas abertas e fechadas}

Na visão de Wallace (1998, p. 124), "usamos questionários e entrevistas quando queremos obter informações diretas sobre o conhecimento, opiniões, ideias e experiências de nossos alunos, companheiros de trabalho ou outros". Nesse sentido, esta pesquisa contou com um questionário aplicado nos dados gerais (a um professor de Espanhol ou assistente administrativo das escolas pesquisadas) com o objetivo de conhecer a realidade das escolas em sentido estrutural, e nos dados específicos (aos alunos participantes desta pesquisa, oriundos das duas turmas analisadas), com o objetivo de identificar o contato; as expectativas, os desejos, as frustrações e as necessidades dos alunos em relação ao ensino de Espanhol na escola pública. Estes questionários foram constituídos de perguntas abertas e fechadas.

Marconi e Lakatos (2009, p. 89) explicam a diferença entre estas duas modalidades de perguntas. Para as autoras, as perguntas abertas, "também chamadas livres, ou não limitadas, são as que permitem ao informante responder livremente, usando linguagem própria, e emitir opiniões". Nesta investigação, este tipo de pergunta visou respostas subjetivas. Já as perguntas fechadas são aquelas que, de maneira limitada, restringem o participante a alternativas fixas, como por exemplo, sim ou não. As perguntas fechadas neste estudo tiveram o intuito de obter informações generalizadas, que não carecem de um caráter subjetivo.

\subsubsection{Observação participante}

Para compreender a realidade do ensino de Espanhol na prática, a observação neste estudo se fez extremamente necessária. Optei pela observação participante por entender que o pesquisador pode ter dificuldades em seguir à risca as delimitações da observação não participante, pois, em determinadas situações, o envolvimento, ainda que pequeno e não intencional, torne-se uma consequência do processo de pesquisa.

Vista como a forma de observação mais utilizada na pesquisa qualitativa, a observação participante consiste no fato do pesquisador observar como membro, mas também influenciando o que é observado em função de sua participação (FLICK, 2009a, p. 207). 
Para Denzin (1989, p. 157-158, grifo meu), a observação participante é uma "estratégia de campo que combina, simultaneamente, a análise de documentos, a entrevista de respondentes e informantes, a participação e a observação diretas e a introspecção". Em concordância com esse pensamento, os instrumentos aqui apresentados combinam entre si e se complementam, objetivando profundidade e credibilidade aos resultados deste estudo, e visando à triangulação, que será explanada a seguir como o método de análise de dados utilizado nesta pesquisa.

\subsection{Triangulação: exposição a realidades múltiplas}

Visando obter uma compreensão em profundidade do fenômeno estudado, bem como acrescentar complexidade e riqueza a esta investigação, o método de análise de dados utilizado nesta pesquisa foi a triangulação.

Na perspectiva de Flick (2009a, p. 361, grifo meu), a triangulação consiste na “combinação de diversos métodos, grupos de estudo, ambientes locais e temporais e perspectivas teóricas distintas para tratar de um fenômeno", e assim, "assegurar uma compreensão em profundidade do fenômeno em questão" (DENZIN e LINCOLN, 2006, p. 19). Logo, além de acrescentar profundidade, credibilidade e vigor ao estudo, a triangulação possibilita uma exposição a realidades múltiplas, a visões concorrentes do contexto estudado que emergem e se fundem (IBIDEM, p. 20), abarcando vários ângulos para analisar os dados obtidos. Assim sendo, o uso da triangulação não leva a uma visão única do problema, mas a diferentes pontos de vista do objeto estudado, onde diversas informações serão compartilhadas produzindo o que Flick (2009b, p. 62) definiu como "excedente de conhecimento". Este conhecimento na triangulação é produzido em diferentes níveis, e vai além do conhecimento que uma única abordagem possibilitaria.

Denzin (1989) caracterizou quatro tipos de triangulação:

a) De dados: Utilização de diversas fontes de dados;

b) Do investigador: Presença de diversos observadores (ou entrevistadores) em um mesmo estudo,

c) De teorias: Abordagem dos dados tendo em mente perspectivas e hipóteses múltiplas, 
d) Metodológica: O autor discorre sobre a triangulação dentro do método, ou seja, escalas e subdivisões dentro de um mesmo método, e a triangulação entre métodos, que seria de fato, utilizar dois métodos ou mais.

Cabe destacar que todas essas formas de triangulação propostas por Denzin (IBIDEM) visam enriquecer e complementar o conhecimento, assim como ir além dos potenciais epistemológicos limitados do método individual.

Nesta investigação a triangulação dos dados ocorreu a partir:

a) Dos dois métodos utilizados (Estudo de caso e Análise documental),

b) Dos dois casos estudados: Taguatinga e Paranoá,

c) Dos diferentes instrumentos de coleta de dados (notas de campo; entrevistas e análise de suas narrativas, questionários e observação participante).

Por fim, a triangulação também é considerada uma alternativa para a validação, pois acrescenta complexidade ao fenômeno estudado, apresentando diversas realidades não em forma linear ou sequencial, porém, simultaneamente.

\subsection{Cenário da pesquisa}

Esta pesquisa foi desenvolvida nas RAs Taguatinga e Paranoá. Como elucidado anteriormente, a pesquisa de campo da presente investigação ocorreu em dois momentos, sendo que cada momento abarcou um cenário especifico, que será apresentado a seguir:

1) Primeiro momento (Coleta de dados gerais): Ocorreu nas escolas públicas de Ensino Médio das duas regiões, com o intuito de traçar o panorama geral do ensino de Espanhol no DF, levando em conta dados condizentes a número de alunos e turmas de Ensino Médio em cada RA; recursos e material didático para alunos e professores, carga horária da disciplina, ano de implantação da Lei 11.161/2005, perfil dos professores de Espanhol da RA abordada, entre outros fatores.

2) Segundo momento (Coleta de dados específicos): Ocorreu em duas escolas, uma situada em Taguatinga e a outra situada no Paranoá, visando dados específicos referentes à realidade vivenciada em sala de aula por professores e alunos. Em cada uma dessas escolas, observei a realidade de uma turma de $3^{\circ}$ ano do Ensino Médio. 
Optei por analisar somente uma turma de cada escola levando em consideração a necessidade de apresentar a realidade com profundidade.

A escolha por essas regiões para compor esta pesquisa não foi feita de modo aleatório, pelo contrário, houve motivações concretas que me levaram a realizar o presente estudo nessas localidades.

Primeiramente, optei por realizar esta investigação em Taguatinga levando em consideração minha história de vida. Cursei o Ensino Médio em uma escola pública de Taguatinga pela qual me apaixonei em minha adolescência e ainda sou imensamente grata.

Ainda como estudante, enxergava as dificuldades enfrentadas pelos professores e alunos, e sonhava com uma realidade de ensino diferente para pessoas como eu. Cinco anos após me formar no Ensino Médio, realizando um sonho, habilitada, retornei à mesma escola, porém, como professora de Espanhol. Esta experiência (acrescida de outras experiências como professora de Espanhol na Secretaria de Educação do Distrito Federal e em instituições privadas) me proporcionou inúmeras reflexões a respeito das condições de ensino do Espanhol na escola pública, motivando-me a descobrir como estava ocorrendo o ensino desta língua na região administrativa na qual me formei, e o que poderia ser feito para melhorar essas condições de ensino.

Posteriormente, optei pelo Paranoá como a segunda região estudada nesta pesquisa tendo em vista ter sido esta a região do "programa-piloto" (LASECA, 2008, p. 155), ou seja, a primeira região administrativa do DF a implantar o Espanhol nas escolas públicas do DF, pois oferece o Espanhol desde 2006, um ano após a publicação da Lei 11.161/2005. Um fator relevante e que também me instigou a incluir o Paranoá nesta pesquisa foi o fato de se tratar de uma região considerada carente, mas considerada hoje referencia no ensino de Espanhol no DF.

Com base nisso, julguei significativo traçar um contraste entre essas duas RAs, visto que são consideradas socialmente e economicamente distintas ${ }^{69}$, ou seja, apresentam realidades diferenciadas, o que torna este contraste ainda mais proeminente, bem como analisar se as realidades do ensino de Espanhol em Taguatinga e no Paranoá são semelhantes, ou se diferem.

\footnotetext{
${ }^{69}$ A PDAD 2013 (Pesquisa Distrital por Amostra de domicílios) realizada pela CODEPLAN (Comissão de Planejamento do Distrito Federal) revela o predomínio da classe C em Taguatinga e da classe D no Paranoá.
} 


\subsection{Participantes da pesquisa}

Na coleta de dados gerais os participantes desta pesquisa foram os professores de Espanhol das escolas de Ensino Médio pesquisadas nas duas RAs, bem como alguns assistentes administrativos (tais como coordenadores, bibliotecários, diretores, etc).

Quanto aos dados específicos, os participantes foram as duas professoras das turmas analisadas e os alunos de cada turma.

\subsection{Aspectos éticos}

Em concordância com Paiva (2005, p. 2, grifo meu), "é importante que a ética conduza as ações de pesquisa, de modo que a investigação não traga prejuízo para nenhuma das partes envolvidas". Com base nisso, percebo que a ética deve estar presente em todos os momentos da pesquisa, desde a coleta de dados, seu desenvolvimento até os resultados do estudo. Logo, ao realizar esta investigação, procurei seguir todos os trâmites éticos.

No primeiro momento de coleta de dados (realizado nas escolas de Ensino Médio das duas RAs), me identifiquei, apresentei uma declaração que evidenciou que eu estava desenvolvendo uma investigação junto à Universidade de Brasília, e pedi autorização para realizar a pesquisa, expondo os objetivos da mesma com clareza. Também pedi aos diretores que assinassem um termo de consentimento ${ }^{70}$ para que eu pudesse coletar os dados na instituição.

$\mathrm{Na}$ coleta de dados específicos, conversei claramente com as duas professoras participantes da pesquisa acerca dos objetivos e metas da mesma, e elas também assinaram um termo de consentimento ${ }^{71}$, juntamente com os diretores de cada escola. No que diz respeito aos alunos, conversei com cada turma e expus a pesquisa, aclarando que necessitaria da participação deles. Logo, os que aceitaram participar da investigação assinaram um termo de consentimento ${ }^{72}$ autorizando a utilização dos dados obtidos. Os menores de 18 anos tiveram seus termos assinados por seus pais ou responsáveis ${ }^{73}$.

Vale salientar o cuidado ao fazer investigação em escolas públicas, pois, "apontar as falhas no ensino público sem trazer nenhum retorno para os pesquisados apenas contribui para

\footnotetext{
${ }^{70}$ Apêndice A.

${ }^{71}$ Apêndice B.

${ }^{72}$ Apêndice C.

${ }^{73}$ Apêndice D.
} 
desestabilizar o que já está fragilizado" (IBIDEM, p. 4). Desse modo, ainda que esta investigação tenha buscado apresentar a realidade do ensino de Espanhol no DF e isso tenha acarretado, consequentemente, na demonstração de pontos positivos e negativos, tenho em mente a necessidade e a obrigação de trazer um retorno aos pesquisados, para que de fato, essa realidade possa ser transformada nos pontos em que ainda está deficiente, através de propostas e sugestões de melhoria que este trabalho propõe.

Sendo assim, no decorrer da pesquisa, constantemente enxerguei a necessidade de "pensar, operando em uma dimensão ética, nos possíveis efeitos e consequências do caminho percorrido pelo pesquisador, interrogando-nos a quem eles podem atingir/beneficiar/prejudicar, e de que forma" (FABRÍCIO, 2006, p. 60).

\subsection{Período de coleta de dados}

Os dados gerais desta pesquisa foram coletados entre os meses de março e abril de 2014, ao passo que os dados específicos foram coletados entre os meses de abril e agosto de 2014.

Este capítulo teve o propósito de apresentar cada passo do percurso metodológico desta investigação, fazendo aclarações detalhadas acerca de cada decisão referente à metodologia deste estudo, para melhor situar o leitor.

O capítulo a seguir trata-se do abrir das cortinas para que comece o espetáculo: Serão apresentados os dados obtidos e sua referente análise, baseados no que elucidei até este momento. Trata-se das reflexões e considerações obtidas na coleta de dados, bem como o entendimento da importância do ensino de Espanhol em escolas públicas, e a necessidade deste ensino ser otimizado. 


\title{
CAPÍTULO 4
}

\section{ANÁLISE DE DADOS}

\author{
"Que o cientista não fale, \\ que seja o objeto que fala \\ através do seu discurso." \\ (RUBEM ALVES, 1980, p. 24)
}

Compreendendo o conceito de pesquisa como o confronto entre evidências, informações coletadas sobre determinado assunto, conhecimento teórico a respeito desse assunto e os dados coletados (LUDKE e ANDRÉ, 2013), neste capítulo serão apresentados os dados obtidos por meio da presente pesquisa bem como a sua discussão e análise, sintetizando os construtos teóricos e metodológicos aqui apresentados, juntamente com o intuito de alcançar os objetivos deste estudo e responder suas perguntas de pesquisa.

Esta análise de dados abarca a voz dos participantes da pesquisa - tanto os profissionais da Educação entrevistados nas escolas de Taguatinga e Paranoá, as duas professoras do Estudo de Caso e os estudantes das duas turmas observadas -, como os autores que embasaram teoricamente este estudo. Também abarca minha voz como pesquisadora consciente de meu papel reflexivo e interventivo.

A fim de melhor situar o leitor, neste momento cabe retomar os objetivos e as perguntas desta pesquisa, expostos no Capítulo 1:

Quadro 4 - Objetivos e Perguntas de Pesquisa

\begin{tabular}{|l|l|}
\hline \multicolumn{1}{|c|}{ Objetivos da Pesquisa } & \multicolumn{2}{|c|}{ Perguntas de Pesquisa } \\
\hline $\begin{array}{l}\text { 1. Descrever como ocorreu e tem ocorrido } \\
\text { a implantação da Lei 11.161/2005 em } \\
\text { duas Regiões Administrativas do }\end{array}$ & $\begin{array}{l}\text { 1. De que maneira tem ocorrido o } \\
\text { processo de ensino-aprendizagem de } \\
\text { Distrito Federal: Taguatinga e Paranoá. em escolas públicas do } \\
\text { Distrito Federal após a implantação da } \\
\text { Lei 11.161/2005? }\end{array}$ \\
\hline $\begin{array}{l}\text { 2. Analisar se as realidades de ensino com } \\
\text { a implantação da Lei 11.161/2005 } \\
\text { nestas duas regiões são semelhantes ou } \\
\text { se diferem, }\end{array}$ & $\begin{array}{l}\text { 2. Atualmente, quais as limitações } \\
\text { presentes no processo de ensino- } \\
\text { aprendizagem de Espanhol em escolas } \\
\text { públicas do Distrito Federal? }\end{array}$ \\
$\begin{array}{l}\text { 2.1 De que forma a carga horária } \\
\text { destinada à disciplina influencia no } \\
\text { processo de ensino-aprendizagem de } \\
\text { Espanhol? }\end{array}$ \\
\hline $\begin{array}{l}\text { 3. Apresentar os descompassos presentes } \\
\text { nesta implantação, constatando as } \\
\text { limitações e necessidades deste ensino. }\end{array}$ & $\begin{array}{l}\text { Que medidas podem ser tomadas para } \\
\text { melhorar o processo de ensino- } \\
\text { aprendizagem de Espanhol em escolas } \\
\text { públicas do Distrito Federal? }\end{array}$ \\
\hline
\end{tabular}

Fonte: autoria própria 
É válido lembrar que a análise de dados foi dividida em dois momentos: “Dados gerais" e "dados específicos". Cada momento deu-se em um cenário específico e utilizou instrumentos diversos. Optei por dividir a análise em dois momentos como uma forma de melhor organizar os dados obtidos, bem como partir de um panorama geral do ensino de Espanhol nas duas RAs analisadas (Taguatinga e Paranoá), no qual se evidenciou a realidade em sentidos estruturais, até chegar a uma sala de aula de uma escola de cada região, nas quais se evidenciaram as realidades da própria vivência escolar das aulas de Espanhol.

\subsection{O ENSINO DE ESPANHOL NO DISTRITO FEDERAL}

Segundo avaliações, o DF possui um dos melhores sistemas educativos do Brasil. Em seu território se encontram mais de centro e trinta Embaixadas e representações das principais organizações internacionais (LASECA, 2008). Logo, a presença de representações que remetem a LEs e culturas internacionais é muito significativa no DF. Contudo, a realidade do ensino de idiomas não condiz com as avaliações do sistema educativo como um todo: ainda há muito para melhorar, avançar e progredir.

Em pesquisas realizadas próximas ao ano de 2010 (prazo final para cumprimento da Lei 11.161/2005), no DF a média apresentada foi pior que a nacional: Ainda em 2009, das 90 escolas de Ensino Médio na Capital, menos de 10 tinham aulas de Espanhol ${ }^{74}$. Até aquele momento o Governo do Distrito Federal (doravante GDF) ainda não havia realizado concurso para contratar professores de Espanhol para alcançar a meta da implantação, tendo o primeiro concurso ocorrido no final de 2010 e um segundo ocorrido em $2013^{75}$.

Entretanto, o DF possui um ponto positivo: os Centros de Línguas (CIL) e sua sólida estrutura. Presentes em oito RAs, atualmente todos os CILs oferecem cursos de Espanhol ${ }^{76}$ a alunos da rede pública.

Como será demonstrado, grande parte (senão a maioria) das escolas pesquisadas nesta dissertação implantou o Espanhol no ano de 2010, tendo protelado o cumprimento da lei até o

\footnotetext{
${ }^{74}$ Esta informação foi dada pela então secretária-adjunta de Educação, Eunice Santos. Disponível em: $<$ http://educacao.ig.com.br/us/2009/11/14/espanhol+obrigatorio+nas+escolas+esta+longe+de+se+tornar+realida de+9088957.html>. Acesso em 20 de julho de 2014.

É válido ressaltar que a secretária-adjunta, em 2007, declarou que não acreditava que o GDF conseguiria cumprir o prazo estipulado. Disponível em: <http://www.tribunadobrasil.com.br/?ned=2057\&ntc=44532\&sc $=1>$. Acesso em 20 de julho de 2014.

${ }^{75}$ Infelizmente, até hoje, momento no qual escrevo este trabalho, ainda não foram convocados todos os professores de Espanhol aprovados no concurso de 2010, e nem os aprovados no concurso de 2013. Como será demonstrarei, muitas dessas vagas de Espanhol nas escolas regulares têm sido ocupadas por professores de Contrato Temporário e docentes concursados para outras disciplinas.

${ }^{76}$ Em 2014 havia 6.705 alunos matriculados em cursos de Espanhol nos CILs (MESQUITA, 2014).
} 
prazo final. Entretanto, a Lei 11.161/2005 não é a única legislação acerca do ensino de Espanhol no DF.

Ainda em 2005, no dia 8 de novembro foi sancionada a Lei Distrital $n^{\circ} 3.694^{77}$ (anteriormente, PL n 665 de 2003), de autoria do Deputado Paulo Tadeu, que em seu Art. $1^{\circ}$ institui que os estabelecimentos de ensino do DF "são obrigados a oferecer a disciplina de língua espanhola como opção de LE para os alunos do ensino fundamental e médio" (BRASIL, 2005). Em seu parágrafo único, a lei estabelece que o ensino de Espanhol seja implantado progressivamente a partir da $1^{\mathrm{a}}$ série do Ensino Médio, e, em seguida, a partir da $5^{\mathrm{a}}$ série do Ensino Fundamental. Todavia, nove anos após esta lei entrar em vigor, o Espanhol no DF ainda não é ensinado no Ensino Fundamental das escolas públicas regulares, e no Ensino Médio apresenta inúmeros descompassos.

Cabe salientar que em fevereiro de 2006, o então Governador do Distrito Federal, Joaquim Roriz, moveu uma ação direta de inconstitucionalidade (ADI $3669^{78}$ ) contra esta lei. Porém, tal ação foi rejeitada em junho de 2007 pelo Supremo Tribunal Federal (STF), visto que a lei distrital não possuía nenhuma disposição contrária à Constituição. Esta ação atrasou por dois anos qualquer medida, sendo a primeira delas a Resolução $\mathrm{n}^{\circ} 1$ de 13 de março de $2007^{79}$ do Conselho de Educação do Distrito Federal, que estabeleceu a língua espanhola como componente curricular da Educação Básica do DF, e sua implantação deveria ser "de acordo com as condições e possibilidades do Sistema de Ensino e das instituições educacionais" (BRASIL, 2007). Aqui, cabe a reflexão: Que motivações levaram o Governador Joaquim Roriz a querer anular esta lei? A quem tal anulação beneficiaria?

Portanto, ainda que o DF possua duas Leis (uma federal e uma distrital) regulamentando o ensino de Espanhol, a implantação desta língua se deu de maneira tardia em solo brasiliense. Somente na RA do Paranoá o Espanhol foi oferecido desde 2006 como programa-piloto em suas três escolas de Ensino Médio, sendo este fator decisivo para que esta região fosse uma das regiões estudadas nesta dissertação.

\subsubsection{Panorama Socioeconômico e Educacional das RAs Taguatinga e Paranoá}

Visto que esta pesquisa pretende fazer um contraste acerca da realidade do ensino de

\footnotetext{
77 Anexo D.

Essa ADI está disponível em: sstf.jusbrasil.com.br/jurisprudência/756822/acao-direta-deinconstitucionalidade-adi-3669-df >. Acesso em: 25 jun. 2014.

${ }^{79}$ Essa resolução está disponível em: 〈www.simprodf.org.br/wp-content/uploads/2011/03/resoluÇÃo-n ${ }^{\circ}$-01-de13-de-marCo-de-2007.pdf>. Acesso em: 26 jun. 2014.
} 
Espanhol em duas RAs do DF, optou-se pela realização de um Estudo de casos múltiplos (YIN, 2010) ou coletivo (STAKE, 1995), que contém mais de um caso (podendo este abarcar mais de uma escola, mais de um professor, etc). O estudo de caso desta pesquisa compreende as RAs Taguatinga e Paranoá. Assim, a fim de proporcionar uma melhor compreensão das muitas diferenças existentes entre essas duas RAs, julguei necessário traçar um breve panorama socioeconômico e educacional de cada uma delas.

Com um território de $121,34 \mathrm{~km}^{2}$ e uma população estimada em 214.282 habitantes $\left(\right.$ CODEPLAN $^{80}, 2013$ b), Taguatinga (RA - III $^{81}$ ) foi fundada em 1958, em função do superpovoamento da Cidade Livre (hoje Núcleo Bandeirante), pois esta já não tinha condições de abrigar os inúmeros trabalhadores que chegavam para construir a nova capital. Devido ao seu crescimento populacional, posteriormente Taguatinga foi desmembrada em outras quatro RAs: Ceilândia e Samambaia (1989), Águas Claras (2003) e Vicente Pires (2009).

Considerada a "Capital do Comércio do DF", Taguatinga é conhecida por possuir características de cidade grande, urbanizada, tendo em vista que conta com um grande polo comercial. Com um considerável desenvolvimento econômico, recebe muitos habitantes de outras RAs em seu sistema de saúde, educacional e empregatício.

A Pesquisa de amostra de domicílios (doravante PDAD, 2013) mostrou que a RA de Taguatinga apresenta independência em relação às atividades comerciais, pois, à exceção de cultura e lazer, praticamente todas as outras categorias (compras, saúde, estudos, etc) são realizadas na própria região.

Já a RA Paranoá (RA - VII), é imensamente maior do que Taguatinga. Seu território é de $853,33 \mathrm{~km}^{2}$, porém a estimativa de sua população é de apenas 45.613 habitantes. Portanto, apesar do extenso território, trata-se de uma RA com características de cidade pequena, considerada uma das regiões mais carentes do DF, tendo sido palco de inúmeros problemas sociais como alto índice de violência, consumo e tráfico de drogas.

Enquanto Taguatinga foi fundada de forma legal, a criação do Paranoá se deu de maneira desordenada e irregular, quando no ano de 1957 pioneiros que trabalhavam na construção da barragem do Lago Paranoá acamparam no local, e ali permaneceram após o término da obra. Após três anos o acampamento já contava com cerca de três mil moradores em 800 barracos. Logo, em função dessa situação, em 1964 foi criada a RA do Paranoá.

\footnotetext{
${ }^{80}$ Esses dados foram obtidos por meio da Pesquisa Distrital por Amostra de Domicílios (PDAD) realizada pela Codeplan (Companhia de Planejamento do Distrito Federal).

${ }^{81}$ No DF as Regiões Administrativas (RAs) são numeradas pela ordem, sequência de sua criação. Logo, Taguatinga foi a $3^{\mathrm{a}}$ região administrativa (cidade) criada no DF.
} 
Assim, é possível visualizar essas duas RAs no mapa abaixo:

Figura 2 - Regiões Administrativas do Distrito Federal

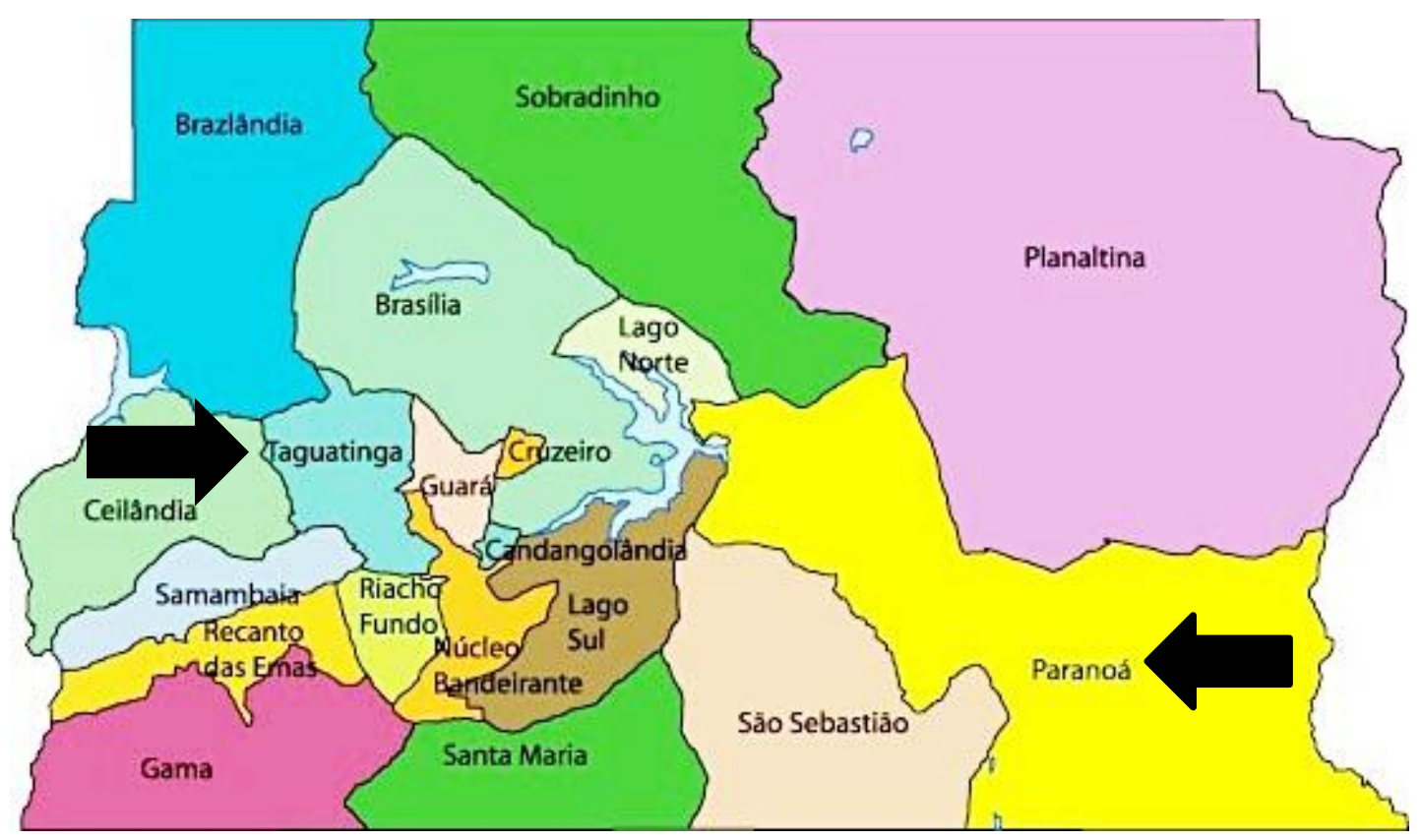

Taguatinga: "Capital do Comércio", desenvolvida, urbanizada, populosa.

Paranoá: Possui características de "cidade pequena", carente, baixa população.

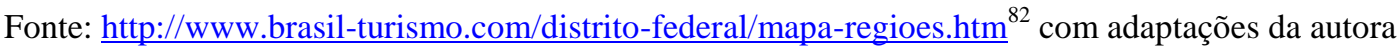

No que tange à questão socioeconômica, a população de Taguatinga possui uma condição consideravelmente melhor do que a população do Paranoá. Tal evidência é constatada, por exemplo, nos programas de transferência de renda: 11,73\% dos domicílios do Paranoá recebem "Bolsa Família”, enquanto este percentual em Taguatinga é de apenas 1,78\% (CODEPLAN, 2013b). Essa evidência se confirma ao observar a Renda Domiciliar Média Mensal e a Renda Per Capital de cada região:

Tabela 4 - Renda Domiciliar Média Mensal e Per Capita Média Mensal - Taguatinga x Paranoá (2013)

\begin{tabular}{|c|c|c|}
\hline Região Administrativa (RA) & $\begin{array}{c}\text { Renda Domiciliar Média } \\
\text { Mensal }\end{array}$ & $\begin{array}{c}\text { Renda Per Capital Média } \\
\text { Mensal }\end{array}$ \\
\hline Taguatinga & $\mathbf{R} \$ \mathbf{5 . 1 3 8 , 5 8}\left(7,58 \mathrm{SM}^{83}\right)$ & $\mathbf{R} \mathbf{1 . 6 3 9 , 0 4}(2,42 \mathrm{SM})$ \\
\hline Paranoá & $\mathbf{R} \$ \mathbf{2 . 6 3 3 , 6 7}(3,88 \mathrm{SM})$ & $\mathbf{R} \mathbf{\$ 7 3 7 , 5 0}(1,09 \mathrm{SM})$ \\
\hline
\end{tabular}

Fonte: Codeplan (Pesquisa Distrital por Amostra de Domicílios) Taguatinga/Paranoá - PDAD 2013

82 Retirado do Brasil Turismo, Guia Geográfico. Disponível em: <http://www.brasil-turismo.com/distritofederal/mapa-regioes.htm>. Acesso em 10 de setembro de 2013.

${ }^{83}$ SM: Salário mínimo. O Decreto 8.166/2013 instituiu o valor do salário mínimo no Brasil em R \$ 724,00. 
Desse modo, segundo os dados da PDAD 2013, observa-se o predomínio da classe C em Taguatinga e da classe D no Paranoá ${ }^{84}$.

No que se refere à instrução da população, $27 \%$ da população de Taguatinga é estudante, sendo que deste percentual, $15,71 \%$ frequentam a escola pública e 11,41\% frequentam a escola particular, ou seja: a diferença de estudantes em escolas públicas e escolas privadas é pouca nessa RA. Entretanto, no Paranoá, dos 30,08\% da população estudante, grande maioria $(24,45 \%)$ frequenta a rede pública contra somente 5,63\% frequentando instituições privadas.

Quanto ao nível de escolaridade, em Taguatinga apenas 1,47\% declarou ser analfabeta, ao passo em que no Paranoá este percentual sobe para 4,48\%, aumentando para $8,41 \%$ quando somado aos que somente sabem ler e escrever e aos que fizeram curso de alfabetização de adultos (CODEPLAN, 2013a). É pertinente destacar que em Taguatinga há 3.455 habitantes com cursos de especialização, 853 com Mestrado e 171 com Doutorado, totalizando 2,09\% da população com cursos de pós-graduação. Em contrapartida, no Paranoá apenas 138 habitantes possuem cursos de especialização, 28 possuem Mestrado e 28 possuem Doutorado, totalizando $0,42 \%$ da população com cursos de pós-graduação.

\subsection{DADOS GERAIS: DELIMITAÇÃO}

Os dados gerais desta pesquisa foram coletados entre os meses de março e abril de 2014, nas escolas públicas de Taguatinga e Paranoá que oferecem Ensino Médio. Além da pesquisa de campo, foram utilizadas notas de campo, um questionário e uma entrevista semiestruturada, bem como informações obtidas em conversas informais, cedidas e consentidas por seus participantes. Apesar da utilização (e necessidade) dos instrumentos citados, o questionário e a entrevista foram os principais. Esses instrumentos objetivaram:

1) Questionário: levantar informações gerais referentes à situação do ensino de Espanhol nas referidas escolas.

2) Entrevista: Conhecer o pensamento dos professores de Espanhol e assistentes no que se refere às suas realidades de ensino de Espanhol: suas impressões; satisfações, insatisfações, necessidades, anseios e sugestões.

\footnotetext{
${ }^{84}$ Para saber mais sobre cálculos de classe social: $<$ http://blog.thiagorodrigo.com.br/index.php/faixas-salariaisclasse-social-abep-ibge?blog=5>. Acesso em 10 de setembro de 2013.
} 


\subsubsection{O questionário: Conhecendo as escolas}

Ao chegar às escolas, o primeiro instrumento de que lancei mão foi um questionário ${ }^{85}$, preenchido por somente uma pessoa em cada escola (podendo esta pessoa ser da coordenação pedagógica ou um docente de língua espanhola, desde que conhecesse bem a instituição e seu funcionamento). As informações solicitadas foram: de caráter geral para situar a implantação e a realidade atual do Espanhol; o perfil dos docentes de Espanhol, os recursos de uso dos professores em momento de coordenação, os materiais didáticos impressos e os materiais de apoio tecnológico para uso do professor em sala de aula.

Cabe destacar que para preservar as instituições não citarei seus nomes, nomeando-as de E (escola), primeira letra de sua RA (Taguatinga - T, Paranoá - P) e uma numeração sequencial. Exemplo: ET1 (Escola 1 de Taguatinga). O mesmo ocorrerá na transcrição das entrevistas com os docentes e assistentes administrativos. Exemplo: Para professores - P1ET1 (professor 1 da escola E1 de Taguatinga), e para assistente administrativo: A1ET1 (assistente 1 da escola E1 de Taguatinga).

\subsection{A implantação do Espanhol em Taguatinga - DF e a realidade atual}

No primeiro bimestre de 2014, Taguatinga contava com oito escolas públicas oferecendo Ensino Médio, nas quais estavam matriculados 9.796 alunos, divididos em 262 turmas $^{86}$. A seguir, elucidarei de forma breve como se deu a implantação em cada escola e como é a realidade do ensino de Espanhol atualmente.

\subsubsection{ET1}

No dia 10 de março de 2014 visitei a ET1. Trata-se de uma escola grande, com 1.415 alunos matriculados no Ensino Médio no $1^{\circ}$ bimestre de 2014, divididos em 38 turmas.

Esta escola implantou o Espanhol no ano de 2010, não podendo o aluno optar por não cursar a disciplina. Atualmente a carga horária da disciplina é de somente uma aula semanal de 50 minutos. Logo, isso faz com que o professor de Espanhol na ET1, além de ministrar

\footnotetext{
${ }_{86}^{85}$ Este questionário encontra-se ao final desta dissertação, no Apêndice E.

86 Censo Escolar 2014 (Rede pública) Turmas e Matrículas. Disponível em: $<$ http://www.cre.se.df.gov.br/ascom/documentos/censo/2014/turmas_matr\%C3\%ADculas_2014.pdf $>$ Acesso em 10 de agosto de 2014.
} 
aulas de Espanhol, precise completar sua carga horária com as disciplinas $\mathrm{PD}^{87}$ e língua portuguesa, não tendo outra opção, submetendo-se assim, ao ensino de disciplinas que muitas vezes não domina.

Hoje a escola possui dois professores de Espanhol, um pela manhã e outro à tarde. Trata-se de dois professores efetivos com 40h, com licenciatura dupla em Português e Espanhol. P1ET1 possui 9 anos de Secretaria de Educação e tem pós-graduação, ao passo em que P2ET1 possui 15 anos de Secretaria, sem pós-graduação. Cada um desses professores além de ministrar aulas de Espanhol, Português e PD, atende 19 turmas, a saber, todas as turmas de seu turno. A área do concurso dos dois professores é Língua Portuguesa. Nessa escola a sala é ambiente ${ }^{88}$.

Na sala de coordenação há somente um computador com acesso à internet e rede wi-fi para uso dos professores, porém não há impressora nem materiais na língua espanhola. Os professores podem reproduzir material, mas com número limitado de cópias. No tocante a materiais impressos, a realidade é desanimadora: Há poucos dicionários na biblioteca (de acordo com a bibliotecária, "uns 3 ou 4"), não há livros de literatura em Espanhol e tão pouco gramaticas, livros didáticos, jornais ou revistas. Há um laboratório de informática em bom uso e em funcionamento e uma sala de vídeo com acesso à televisão, aparelho de som, Datashow e DVD, devendo o professor reservar a sala com antecedência.

O Espanhol nesta escola é classificado com uma disciplina igual às demais, reprovando como qualquer outra. A ET1 tem em vista implantar o PROEMI (Ensino Médio Integrado), com projetos para varias disciplinas, inclusive para redação e LEM. Uma verba já foi disponibilizada para que o projeto entre em andamento. Por fim, a escola realiza a "Amostra Cultural", que consiste em pesquisa e apresentações sobre a cultura e realidade de países que falam Inglês e Espanhol. Neste projeto são abarcadas diferentes modalidade de cultura, tais como curiosidades dos países, gastronomia, danças, etc.

\subsubsection{ET2}

No dia 13 de março de 2014 visitei a ET2. No primeiro bimestre de 2014 havia 2.527 alunos matriculados no Ensino Médio nesta escola, divididos em 66 turmas.

\footnotetext{
${ }^{87}$ PD: Parte diversificada. Posteriormente, elucidarei detalhes desta disciplina.

${ }^{88}$ Sala Ambiente: Os alunos que se locomovem entre uma aula e outra e o docente permanece fixo em uma única sala ao longo do dia.
} 
A ET2, assim como a ET1, acrescentou o Espanhol na grade curricular no ano de 2010, sem o aluno ter a opção de cursar a disciplina. Desde então, a disciplina possui somente uma aula semanal de 50 minutos.

Há duas professoras de Espanhol na ET2: P1ET2 é efetiva, com 40h. Atuante na Secretaria de Educação há 25 anos é licenciada em Espanhol e Português, sem pós-graduação, com área de concurso Língua Portuguesa. P2ET2 é contrato temporário, 40h, licenciada somente em Espanhol, sem pós-graduação. Cabe destacar que esta última professora foi aprovada no último concurso para professor efetivo (2013) em excelente colocação, porém, ainda não foi convocada. As duas professoras ministram somente aulas de Espanhol, cada uma atendendo a um turno (matutino e vespertino), possuindo assim, o considerável número de 28 turmas cada uma. Nesta escola a sala é ambiente.

$\mathrm{Na}$ sala de coordenação há computadores e acesso à internet, bem como livros e revistas referentes ao ensino de Espanhol. Não há impressora, contudo, os professores podem reproduzir material de maneira flexível. No que tange a materiais impressos, segundo a bibliotecária, a escola não possui mais que cinco dicionários de Espanhol. Não há livros de literatura na língua, somente poucas obras traduzidas em Português. Há duas gramaticas de auxílio para o aluno e não há revistas nem jornais em Espanhol.

A escola possui um laboratório de informática em uso e em boas condições. Conta também com o sistema moodle, no qual são dadas aulas virtuais, utilizando assim, as novas tecnologias. É válido ressaltar que esta escola possui uma sala multimídia bem equipada na qual cabem até 4 turmas. Cada sala de aula possui uma televisão plana com entrada hdmi, que, segundo as professoras, auxilia muito a execução das aulas. A escola também disponibiliza televisão, DVD, Datashow e som.

Por fim, a ET2 não possui nenhum projeto referente à LEM, e a língua espanhola reprova o aluno como qualquer outra da grade curricular.

\subsubsection{ET3}

No dia 14 de março de 2014 visitei a ET3, que no primeiro bimestre de 2014 contava com 1.456 matrículas no Ensino Médio, em 36 turmas. Eu não conhecia esta escola, mas ouvia acerca de seu ensino de qualidade, o que foi comprovado quando, ao chegar à escola, vi uma faixa de parabenização aos 40 alunos aprovados no PAS da UnB em 2013, um número apreciável para uma escola pública. Todavia, a realidade encontrada na ET3 não difere muito 
das realidades das escolas ET1 e ET2.

A escola implantou o Espanhol à grade curricular em 2010. Vale destacar que quando perguntei à professora de Espanhol se o aluno teve opção em estudar a língua, ela respondeu: “não, porque era obrigatório, né". Nisso percebe-se a falta de conhecimento do teor da lei, porquanto somente a oferta era obrigatória, devendo a matrícula ser facultativa (Art. $1^{\circ}$ ).

A carga horária do Espanhol na ET3 é de uma aula semanal de 50 minutos, e a disciplina reprova como qualquer outra da grade curricular. Atualmente a escola possui duas professoras de Espanhol: P1ET3 é efetiva, com 40h, e atua na Secretaria de Educação há 26 anos. É concursada para Atividades e tem formação em Pedagogia e Licenciatura Dupla em Espanhol e Português. P2ET3 é efetiva, 40h, concursada para Atividades (como não tive acesso $^{89}$ a essa professora pessoalmente, não obtive os dados completos de sua formação). Cada professora possui 18 turmas (todas de seu turno) e ministra aulas de Espanhol e PD. A sala de aula é sala é ambiente.

Na sala de coordenação há computadores, internet e não há impressora, porém, os professores têm acesso a cópias de maneira flexível. Não há material em Espanhol nesta sala, somente o livro didático do professor. Em relação aos materiais impressos, a ET3 possui dicionários suficientes para que os alunos utilizem em sala e alguns poucos livros de literatura. Em contrapartida, não há livros didáticos e nenhuma gramática, nem jornais e revistas. A escola também possui um laboratório de informática em uso e em boas condições, e todas as salas de aula são equipadas com televisão e Datashow. Não há na ET3 nenhum projeto referente ao ensino de LEM.

\subsubsection{ET4}

No dia 17 de março visitei a ET4. No primeiro bimestre de 2014 esta escola possuía 1.312 alunos, divididos em 33 turmas.

A ET4 implantou o Espanhol em 2010, e o aluno não teve opção em não estudar a língua. Assim como as demais, a carga horária do Espanhol é de apenas uma aula semanal de 50 minutos.

Hoje na escola existem duas professoras de Espanhol: P1ET4 é contrato temporário, 40h, licenciada em Português e Espanhol, sem pós-graduação. Possui 16 turmas. P2ET4 é

89 Infelizmente nem todos professores se dispuseram a atender-me, e outros não consegui encontrar pessoalmente. A todos esses disponibilizei o questionário para que me enviassem via $e$-mail ou para que eu pegasse na escola posteriormente. Porém, não obtive resposta por parte deles. Decidi, assim, como uma maneira de respeitá-los, não buscar informações sobre eles além das repassadas pela instituição escolar. 
efetiva, 40h, concursada para a área de Português com licenciatura dupla em Português e Espanhol, e possui pós-graduação. Ela trabalha na Secretaria de Educação há mais de 20 anos e possui 19 turmas. As duas professoras ministram aulas de Português e Espanhol, atendendo a todas as turmas de seu turno. A sala é ambiente somente pela tarde, pois pela manhã o número de turmas é maior.

Na sala de coordenação há computadores e impressora, e os professores têm acesso a cópias de forma flexível. A coordenadora não soube me informar se nesta sala havia material referente ao Espanhol. Em relação aos materiais impressos, em Espanhol eram pouquíssimos, não mais que 5 ou 6 dicionários e somente isso, literalmente: não havia livros de literatura, gramáticas, livros didáticos, nem periódicos.

A ET4 possui laboratório de informática com computadores antigos, entretanto não está em uso, visto que não há professores responsáveis por ele. Contudo, há uma equipe desenvolvendo um projeto para que o laboratório seja ativado novamente. Há uma sala de multimídia com televisão e Datashow, necessitando o professor reservar a sala para seu uso. Por fim, a escola atualmente não possui nenhum projeto relacionado à LEM, e o Espanhol conta para reprovação como todas as outras disciplinas da grade curricular.

\subsubsection{ET5}

No dia 20 de março visitei a ET5. No primeiro bimestre de 2014 esta escola contava com 1.032 alunos divididos em 32 turmas.

A ET5 implantou o Espanhol no ano de 2010, e o aluno não pôde optar por não estudar a língua. Com carga horária de uma aula semanal de 50 minutos para o Espanhol, esta é a escola de Taguatinga que apresenta o maior número de docentes de língua espanhola, a saber: 2 professoras no turno matutino, 1 professora no turno vespertino e 1 professora no noturno, totalizando 4 docentes.

P1ET5 é efetiva, com carga horária de 20h, e tem 15 anos na Secretaria da Educação. É concursada para Português com dupla habilitação em Português e Espanhol, e possui pósgraduação. Ministra aulas de Espanhol, Português e PD, e possui 12 turmas. P2ET5 é efetiva, 20h, concursada para Português, com dupla habilitação em Português e Espanhol. Na Secretaria de Educação há 21 anos, não possui pós-graduação e ministra somente aulas de Espanhol para 12 turmas. A professora P3E5 foi aprovada no concurso para professor efetivo realizado em 2010. Licenciada em Espanhol, não possui pós-graduação e sua área de concurso 
é LEM Espanhol ${ }^{90}$, 20h. Esta professora tem 16 turmas e ministra somente aulas de Espanhol. Infelizmente não consegui informações sobre a professora do turno noturno ${ }^{91}$.

Um fator relevante é que a escola desenvolve um projeto específico de LE, o Festival cultural, onde os alunos cantam, dançam e propagam a culinária dos países. Em 2014 o festival ocorreu em julho e focalizou os países da Copa do mundo. Uma das coordenadoras do Festival é uma professora de Espanhol.

Na sala de coordenação há computadores com acesso à internet e impressora, podendo os professores produzir cópias de maneira flexível. Também há uma estante com livros didáticos de várias disciplinas, dentre elas, o Espanhol. No que tange aos materiais impressos, a escola é muito carente: possui de 5 a 8 minidicionários e não há livros de literatura, gramáticas, nem periódicos em Espanhol.

A escola possui dois laboratórios de informática em uso, que são modernos e estão em boas condições. Há sala de multimídia com televisão, Datashow, DVD e som, precisando o professor marcar horário e reservá-la. Por fim, nesta escola a sala é ambiente e a disciplina reprova o aluno como as demais da grade curricular.

\subsubsection{ET6}

No dia 21 de março de 2014 visitei a ET6. Essa foi a primeira escola na qual não fui bem recebida e tive dificuldades para conseguir as informações que buscava. Entretanto, os percalços fazem parte da pesquisa e não barram o pesquisador, pelo contrário, o instigam a ir além, e foi o que aconteceu.

A ET6 é uma escola pequena, e no primeiro bimestre de 2014 possuía 704 alunos matriculados, divididos em 20 turmas. Diferente das outras escolas, a ET6 implantou o Espanhol no ano de 2009, porém o aluno não teve opção em não estudar a língua. Como nas demais, a carga horária da disciplina é de somente uma aula semanal de 50 minutos.

Também de forma diferente das demais, a ET6 oferece Ensino Médio pela manhã e EJA (Educação de Jovens e Adultos) à tarde, sendo que no EJA não há oferta de Espanhol. Dessa forma, a escola possui somente uma professora de Espanhol que atua no Ensino Médio: P1ET6 é contrato temporário, com 40h de carga horária, e possui a seguinte formação: licenciada somente em Espanhol, tem pós-graduação e também ministra aulas em uma

\footnotetext{
${ }^{90}$ Vale ressaltar que dos 7 docentes efetivos já mencionados, esta é a primeira professora com área de concurso "LEM Espanhol". Os demais têm sua área de concurso "Língua Portuguesa" e "Atividades".

${ }^{91}$ Não encontrei pessoalmente os professores do turno noturno por impossibilidades de ir às escolas neste horário. A todos deixei o questionário, entretanto, infelizmente nenhum me respondeu.
} 
faculdade particular. Esta professora, na época em que realizei esta coleta de dados, era a próxima docente $40 \mathrm{~h}$ a ser convocada no concurso de professor efetivo realizado em 2010 . Na ET6 possui 20 turmas e ministra aulas de Espanhol, redação e PD.

Na sala de coordenação há computadores, porém sem acesso à internet. Há impressora e os professores podem fazer cópias de maneira flexível. Não há materiais em Espanhol na sala. Em relação aos materiais impressos, esta escola possui uma realidade animadora, visto que a bibliotecária possui curso de Espanhol e é apaixonada pela língua. Logo, há livros de literatura espanhola e chilena, mas somente obras traduzidas, pois, como a própria bibliotecária disse, "os alunos não têm o costume de ler na língua". A maioria dessas obras são doações da própria bibliotecária. Em contrapartida, há no máximo 10 dicionários, e nenhuma gramática, livro didático ou periódico em Espanhol. Vale salientar que a escola recebe verba e solicita livros em Espanhol, entretanto, estes livros não são comprados.

A ET6 possui laboratório de informática, contudo, este não tem suficiente espaço para receber uma turma inteira e a internet é ruim, apesar dos computadores estarem em bom uso. Há sala de multimídia com televisão, Datashow e DVD, e para utilizá-la o professor deve marcar horário. Cabe destacar que em cada sala de aula há uma televisão. Por fim, na ET6 a sala é ambiente, a escola não possui nenhum projeto relacionado à LEM, e o Espanhol reprova como as demais disciplinas.

\subsubsection{ET7}

No dia 24 de março de 2014 visitei a ET7. No primeiro bimestre de 2014 esta escola possuía 797 alunos matriculados, divididos em 23 turmas. Logo, assim como a ET6, esta escola também é uma escola pequena. A ET7 oferece o Espanhol desde 2010, e o aluno não teve opção em não cursar a língua. Semelhante às outras escolas apresentadas, a carga horária da disciplina é de apenas uma aula semanal de 50 minutos.

Por oferecer Ensino Médio pela manhã e Ensino Fundamental à tarde (no qual não se oferta língua espanhola), a ET7 possui somente um professor de Espanhol. P1ET7 foi aprovado no concurso para professor efetivo em 2010. Licenciado em Espanhol, sem pósgraduação e com área do concurso LEM Espanhol, este professor trabalha 40h e possui 20 turmas, nas quais ministra aulas de Espanhol e PD. Nesta escola a sala não é ambiente, ou seja, quem muda de sala é o professor. 
A sala de coordenação da ET7 é precária: não há computadores, nem internet, nem material didático em Espanhol e tão pouco, impressora. Contudo, os professores podem solicitar cópias de maneira flexível. No que tange aos materiais impressos, não há praticamente nada na escola: há poucos dicionários e não há livros de literatura (somente vi o "Dom Quixote" traduzido para o Português). Também não há gramáticas, livros didáticos, nem periódicos.

A escola possui laboratório de informática em uso com poucos computadores, porém recebeu um lote de computadores novos que ainda necessitam ser instalados. Há uma sala de multimídia e também há disponibilidade de televisão, som e Datashow, sendo que para utilizar a sala é necessário somente que o professor marque horário. Por fim, a ET7 não desenvolve nenhum projeto relacionado a LEM, e o Espanhol reprova igualmente às outras disciplinas.

\subsubsection{ET8}

Finalmente, no dia 25 de março de 2014 visitei a última escola de ensino médio de Taguatinga: a ET8. No primeiro bimestre de 2014 esta escola tinha 553 alunos matriculados, divididos em 14 turmas. Portanto, trata-se de uma escola muito pequena, na qual os alunos são da própria comunidade, diferente das demais escolas que abrigam alunos de outras RAs.

A ET8, apesar de pequena, apresentou diferenças consideráveis em relação às demais. Inicialmente, por ter implantado o Espanhol em 2011, sem opção do aluno por não cursar a disciplina. Em segundo lugar, por ser a única escola de Ensino Médio de Taguatinga que atua em regime de semestralidade ${ }^{92}$, ou seja: a carga horária do Espanhol é de duas aulas semanais durante um semestre letivo.

A escola possui projeto de LEM, porém somente de língua inglesa. Por oferecer o Ensino Médio somente pela manhã, esta escola possui apenas um professor de Espanhol, e aqui consiste o dado mais instigante: P1ET8 é efetivo, com carga horária de 40h, licenciado em Geografia e em Espanhol, sendo sua área de concurso "Geografia". Este professor possui

\footnotetext{
92 O Art. 23 da LDB/1996 institui que a educação básica pode ser dividida em séries anuais, períodos semestrais e ciclos. Assim, em 2013 começou a implantação do novo projeto de reorganização da educação básica da rede pública de ensino do DF: A semestralidade, que consiste na organização dos componentes curriculares em dois semestres anuais, com a carga horária dobrada de modo que metade das disciplinas é estudada no primeiro semestre, e as demais, no segundo. Para mais informações sobre a semestralidade: $\langle$ http://www.cre.se.df.gov.br/ascom/documentos/curric_mov/semestral/4ciclo.pdf $>$. Acesso em: 15 de setembro de 2013.
} 
três especializações na área de Geografia e chegou a iniciar um mestrado nessa área. Contudo, atualmente ministra aulas somente de Espanhol em 7 turmas.

Na sala de coordenação há computadores sem acesso à internet, porém há rede wi-fi. Há impressora, e os professores podem fazer cópias de exercícios de maneira flexível. Não há materiais em Espanhol. Quanto aos materiais impressos, em comparação com as outras escolas, trata-se da biblioteca melhor equipada: Há alguns dicionários (uns 15, mais ou menos), boas gramaticas e alguns outros livros didáticos que não o oferecido pelo governo. Contudo, não há livros de literatura nem periódicos em língua espanhola.

$\mathrm{Na}$ escola há laboratório de informática, porém os computadores não estão em boas condições de uso, pois são antigos. Há uma sala de vídeo com televisão DVD e Datashow. Para utilizar esta sala é necessário marcar e agendar horário. É valido ressaltar que esta escola sofreu um assalto em 2012 e os ladrões levaram praticamente todo o equipamento da escola: dois Datashows, máquinas de Xerox, entre outros. Segundo a coordenadora, ainda hoje a escola tenta repor a perda desse assalto. Por fim, a sala é ambiente e o Espanhol reprova como as outras matérias.

\subsubsection{O Panorama geral do ensino de Espanhol em Taguatinga - DF}

Segundo Maciel e Oliveira (2011), é necessário verificar as condições existentes e necessárias para a real efetivação da Lei 11.161/2005. Logo, conforme os dados apresentados, é possível ver que houve muitos descompassos na implantação do Espanhol em Taguatinga, e mesmo atualmente, este ensino apresenta diversas lacunas.

Inicialmente, das oito escolas pesquisadas, seis implantaram o Espanhol somente no ano de 2010 (prazo final para o cumprimento da Legislação), uma implantou em 2009 e uma outra em 2011, extrapolando o prazo final. De fato, como afirmou Aline Oliveira (2010, p. 50 ), houve uma diversidade de posturas adotadas pelas instituições de ensino, pois a maioria esmagadora das escolas postergou esta implantação até não poder mais (GONZÁLEZ, 2009). Vê-se que a Secretaria de Educação do DF não se comprometeu, uma vez que deixou a implantação a cargo das próprias escolas, demonstrando assim, certo "desinteresse" em cumprir a lei (AMARAL e ALMEIDA, 2010). Dessa maneira, mais uma vez concluo que a própria textualidade da lei, confusa e passível de várias interpretações, abriu precedentes para que as secretarias e instituições agissem da forma que melhor lhes parecesse, e a implantação do Espanhol nas escolas de Taguatinga reafirma tal percepção. 
No tocante à lei determinar que a oferta é obrigatória, porém a matrícula facultativa (Art. $1^{\circ}$ ), segundo Amaral e Mazzaro, (2007, p. 4), “é preciso que a escola crie condições para que de fato o aluno possa optar ou não pela língua espanhola”. Todavia, isso não ocorreu nas escolas de Taguatinga: nenhuma delas atendeu ao Art. $1^{\circ}$, pois nas oito escolas pesquisadas o aluno é obrigado a estudar a língua espanhola. Na maioria das instituições percebi que muitos professores; coordenadores e inclusive, diretores, pensam que o aluno é obrigado a estudar Espanhol, cabendo aqui o seguinte questionamento: até que ponto os atores da instituição escolar conheciam a Lei 11.161/2005 ao implantá-la em suas escolas? É possível uma implantação de qualidade sem o conhecimento integral da legislação em questão?

Percebo que nenhuma das escolas pretende atender a este dispositivo da lei, visto que dessa maneira o ensino tem "funcionado". É válido ressaltar que a implantação de uma política linguística requer planejamento (CALVET, 2007), entretanto, constatei que a maioria das escolas não se planejou para implantar o Espanhol, ou não houve o planejamento necessário. A maioria (senão, todas) não possibilitou a opção ao aluno por não ter condições físicas e logísticas para tal, como afirmou o vice-diretor da ET6: "caso o aluno não fizesse Espanhol, como seria coberta essa lacuna de 50 minutos?”. Contudo, é necessário lembrar que as escolas tiveram cinco anos para organizar-se após a sanção da lei, e hoje, nove anos depois, ainda não se realizou nenhuma mudança nesse sentido. Tal atitude (ou falta dela) não descumpre somente a lei federal, mas também a lei distrital, que em seu Art. $1^{\circ}$ estabelece que as escolas do DF são obrigadas a ofertar o Espanhol "como opção de língua estrangeira para os alunos do ensino fundamental e médio”. Assim, em Taguatinga o Art. $1^{\circ}$ de ambas as leis não tem sido cumprido na íntegra.

$\mathrm{Na}$ maioria das escolas foi possível identificar apenas o estudo formal da disciplina, sem efetiva promoção dos conhecimentos culturais que a língua espanhola abrange, uma vez que das oito escolas pesquisadas, somente duas, (ET1 e ET5) desenvolvem um projeto extracurricular de Espanhol como LEM. Um fator talvez mais agravante que a não realização de projetos referentes ao ensino de Espanhol é a realização de projetos somente de língua inglesa, como é o caso da ET8. Assim se percebe que muitas escolas ainda julgam o Inglês mais necessário que o Espanhol, deixando de possibilitar ao aluno um maior contato com essa língua e as diversas culturas por ela abarcadas e contribuindo, como afirmam os PCNEM (BRASIL, 2000, p. 25), para a "redução do interesse pela aprendizagem de outras línguas estrangeiras". 
Logo, nas escolas de Taguatinga não se pratica a interculturalidade que o ensino de Espanhol possibilita, já que estudar uma LE não se resume somente em códigos gramaticais, mas como afirmam os PCNs de 1998, também consiste em primar pela formação do aluno como uma pessoa aberta às diferenças culturais. Nesse sentido, coincido com a visão de Dias (2014, p. 7, grifo meu) ao dizer que a cultura está integrada à língua. Dessa maneira,

\footnotetext{
Neste percurso de "aprender Espanhol na escola" [...] os estudantes têm que aprender a reconhecer a realidade sociocultural que subjaz a todo ato de fala, e compreender a cultura integrada com a língua, já que a língua expressa a cultura e por meio dela adquirimos cultura.
}

Um fator que apresentou similaridade em todas as escolas pesquisadas foi a classificação da disciplina. Todas as escolas afirmaram que o Espanhol conta para a reprovação como qualquer outra disciplina da grade curricular. Porém, inferi que professores e coordenação tiveram dificuldades em classificar a disciplina, e que, de fato, alguns realmente não sabiam como classificar a língua espanhola.

No que se refere aos materiais e recursos (tanto impressos como tecnológicos), as realidades apresentadas foram diversas. Das escolas pesquisadas, a maioria apresentou boa estrutura de sala de coordenação, possibilitando recursos como computadores e internet aos professores, à exceção da ET7 que apresentou uma realidade precária, visto que não havia nem computadores, nem internet, nem material didático em Espanhol e tão pouco, impressora na sala de coordenação. Somente duas escolas (ET2 e ET5) dispunham de material de leitura em Espanhol aos professores. Isso demonstra que a falta de material não atinge somente os alunos, mas os professores também, tendo em vista que estes necessitam estar em constante atualização na língua.

A realidade encontrada nas bibliotecas das escolas pesquisadas também não variou muito de uma escola para outra. Das oito escolas pesquisadas, somente uma (ET3) dispunha de dicionários em número suficiente para uso em sala de aula. Seis escolas (ET1, ET2, ET4, ET5 e ET7) dispunham de no máximo 5 a 10 dicionários para atender a uma escola de Ensino Médio inteira, e a ET8 contava com 15 dicionários. A maioria das escolas não possuía livros de literatura na língua, e quando possuía, eram poucos e tratava-se de obras traduzidas (como o caso das escolas ET2, ET3 e ET6). Somente uma escola (ET8) apresentou diversidade de livros didáticos e gramáticas em Espanhol, ao passo que todas as outras escolas não possuíam nenhum outro livro didático que não fosse o oferecido pelo governo ou gramáticas na língua 
(à exceção da ET2 que tinha em sua biblioteca duas gramáticas de Espanhol). Nenhuma escola dispunha de jornais ou revistas em Espanhol.

Com base no exposto, o que se vê é que as bibliotecas das escolas de Taguatinga ainda não se adequaram à introdução do Espanhol no currículo, pois a maioria delas dispõe de pouco ou nenhum material em Espanhol. Assim, percebe-se a incongruência entre a realidade e a expectativa de aprendizagem presente nas Orientações Curriculares do Distrito Federal (2009, p.68) para o $1^{\circ}$ ano do Ensino Médio: "Manusear adequadamente o dicionário em busca dos significados de palavras do texto". Contudo, como os alunos irão manusear dicionários se na maioria das escolas o número de dicionários não passa de cinco a dez? Ainda que estes poucos dicionários fossem distribuídos em duplas, muitos alunos ficariam sem material de consulta, porquanto uma sala de Ensino Médio de escola pública comporta de 35 a 40 alunos assíduos.

A falta de materiais impressos também se apresenta contraditória à implantação do Espanhol como LEM ao observarmos a valorização que os documentos oficiais (PCNs e OCENS) atribuem à compreensão leitora, como por exemplo, os PCNs de 1998 (BRASIL, 1998, p. 20): “A leitura tem função primordial na escola e aprender a ler em outra língua pode colaborar no desempenho do aluno como leitor em sua língua materna”. Se há a orientação da leitura como uma prática essencial à aprendizagem de LEs na escola, porque estas não disponibilizam livros de literatura; livros didáticos, gramáticas, jornais e revistas aos seus alunos? Até que ponto há a observação das orientações contidas nos documentos oficiais pelas instituições de ensino?

Finalmente, no que se refere aos recursos tecnológicos, das escolas pesquisadas em Taguatinga, todas possuem laboratório de informática, destacando a ET5 que possui dois laboratórios em funcionamento e a ET2 que além do laboratório, utiliza o sistema moodle, contribuindo para a melhoria do ensino de Espanhol, uma vez que as novas tecnologias de informação e comunicação são "aliadas importantes em todos os âmbitos do ensino e podem ser potencializadas na aprendizagem de Língua Espanhola” (DIAS, 2014, p. 8). Contudo, a ET4, apesar de possuir um laboratório, não conta com o mesmo em uso, a ET6 possui um laboratório que não comporta uma sala inteira e o laboratório da ET7 tem poucos computadores. Dessa maneira, não basta somente a escola possuir um laboratório de informática: devem existir boas condições de uso e funcionamento.

Todas as escolas possuem pelo menos uma sala de vídeo ou sala de multimídia com televisão, Data Show e DVD. É válido salientar que nas salas de aula das escolas ET2, ET3 e 
ET6 há televisão, proporcionando ao professor a oportunidade de trabalhar utilizando as novas tecnologias em sala de aula.

\subsubsection{A carga horária e os professores de Espanhol de Taguatinga - DF}

Dois fatores merecem ser comentados separadamente: a carga horária do Espanhol e os docentes da disciplina. Segundo a Lei 11.161/2005, a determinação do número de horas de Espanhol corresponde à área estadual, observando os recursos disponíveis. Conforme Laseca (2008, p. 81), "não parece exagerado fixar esta variável em duas horas/semana”. No DF, essa carga horária seria a mínima que se oferece a qualquer disciplina, pois, no Ensino Médio, as disciplinas língua inglesa e PD (integrantes da parte diversificada do currículo juntamente com o Espanhol) possuem duas horas/semanais.

Contudo, em todas as escolas de Taguatinga a carga horária para o Espanhol é de ínfimos 50 minutos (inclusive na ET8 que trabalha em regime de semestralidade, pois a escola ministra duas horas semanais de Espanhol somente por um semestre letivo). Esta carga horária tão reduzida traz uma série de dificuldades ao ensino-aprendizagem de Espanhol, tornando o seu ensino de qualidade uma difícil missão. Observando essas condições, faço-me o mesmo questionamento que GONZÁLEZ (2012, p. 21): "a que espanhol se espera que nossos aprendizes sejam apresentados e expostos?".

Algo que vale salientar é a disciplina Projeto Disciplinar (PD), que possui a carga horária de duas aulas semanais. A orientação para esta disciplina é cada escola definir como trabalhá-la, priorizando temas transversais de acordo com as necessidades e peculiaridades locais. Algumas escolas trabalham o PD com seriedade, porém em outras a disciplina não é trabalhada de forma eficaz, pois, muitas vezes, o próprio professor de PD acaba escolhendo o que trabalhar na matéria, tornando o PD uma extensão da sua disciplina, ou simplesmente, "dois horários livres" existentes para preencher carga horária (como afirmam muitos alunos e professores). Assim, o que acontece em muitas escolas são professores "fugindo" do PD, que frequentemente acaba "sobrando" para o professor de Espanhol, por este ser o único com uma aula semanal.

No que se refere aos professores de Espanhol em Taguatinga, o quadro abaixo apresenta uma síntese com o perfil de cada um: 
Tabela 5 - Professores de Espanhol de Taguatinga - DF (2014)

\begin{tabular}{|c|c|c|c|c|c|c|}
\hline Professor & Formação & $\begin{array}{c}\text { Área de } \\
\text { Concurso }\end{array}$ & $\begin{array}{c}\text { Efetivo } \\
\text { ou Cont. }\end{array}$ & $\begin{array}{l}\text { Pós - } \\
\text { Grad. }\end{array}$ & Disciplinas & $N^{\circ}$ de Turmas \\
\hline P1ET1 & $\begin{array}{c}\text { Português e } \\
\text { Espanhol }\end{array}$ & $\begin{array}{c}\text { Língua } \\
\text { Portuguesa }\end{array}$ & $\begin{array}{c}\text { Efetiva há } \\
9 \text { anos }\end{array}$ & $\mathrm{X}$ & $\begin{array}{c}\text { Espanhol, } \\
\text { Português, PD }\end{array}$ & 19 \\
\hline P2ET1 & $\begin{array}{c}\text { Português e } \\
\text { Espanhol }\end{array}$ & $\begin{array}{c}\text { Língua } \\
\text { Portuguesa }\end{array}$ & $\begin{array}{c}\text { Efetivo há } \\
15 \text { anos }\end{array}$ & - & $\begin{array}{c}\text { Espanhol, } \\
\text { Português, PD }\end{array}$ & 19 \\
\hline P1ET2 & $\begin{array}{c}\text { Português e } \\
\text { Espanhol }\end{array}$ & $\begin{array}{c}\text { Língua } \\
\text { Portuguesa }\end{array}$ & $\begin{array}{l}\text { Efetiva há } \\
26 \text { anos }\end{array}$ & - & Espanhol & 28 \\
\hline P2ET2 & Espanhol & $\begin{array}{c}\text { LEM } \\
\text { Espanhol }\end{array}$ & CT & - & Espanhol & 28 \\
\hline P1ET3 & $\begin{array}{l}\text { Pedagogia, } \\
\text { Português e } \\
\text { Espanhol }\end{array}$ & Atividades & $\begin{array}{l}\text { Efetiva há } \\
26 \text { anos }\end{array}$ & - & Espanhol, PD & 18 \\
\hline P2ET3 & $?$ & Atividades & $?$ & $?$ & Espanhol, PD & 18 \\
\hline P1ET4 & $\begin{array}{c}\text { Português e } \\
\text { Espanhol }\end{array}$ & $\begin{array}{c}\text { LEM } \\
\text { Espanhol }\end{array}$ & $\mathrm{CT}$ & - & Português e PD & 16 \\
\hline P2ET4 & $\begin{array}{c}\text { Português e } \\
\text { Espanhol }\end{array}$ & $\begin{array}{c}\text { Língua } \\
\text { Portuguesa }\end{array}$ & $\begin{array}{c}\text { Efetiva há } \\
21 \text { anos }\end{array}$ & $\mathrm{X}$ & Português e PD & 19 \\
\hline P1ET5 & $\begin{array}{c}\text { Português e } \\
\text { Espanhol }\end{array}$ & $\begin{array}{c}\text { Língua } \\
\text { Portuguesa }\end{array}$ & $\begin{array}{c}\text { Efetiva há } \\
15 \text { anos }\end{array}$ & $\mathrm{X}$ & $\begin{array}{c}\text { Espanhol, } \\
\text { Português, PD }\end{array}$ & 12 \\
\hline P2ET5 & $\begin{array}{c}\text { Português e } \\
\text { Espanhol }\end{array}$ & $\begin{array}{c}\text { Língua } \\
\text { Portuguesa }\end{array}$ & $\begin{array}{l}\text { Efetiva há } \\
21 \text { anos }\end{array}$ & - & Espanhol & 12 \\
\hline P3ET5 & Espanhol & $\begin{array}{c}\text { LEM } \\
\text { Espanhol }\end{array}$ & $\begin{array}{c}\text { Efetiva há } \\
\text { 4anos }\end{array}$ & - & Espanhol & 16 \\
\hline P4ET5 & $?$ & $?$ & $?$ & $?$ & $?$ & $?$ \\
\hline P1ET6 & Espanhol & $\begin{array}{c}\text { LEM } \\
\text { Espanhol }\end{array}$ & $\mathrm{CT}$ & $X$ & $\begin{array}{c}\text { Espanhol, } \\
\text { redação, PD }\end{array}$ & 20 \\
\hline P1ET7 & Espanhol & $\begin{array}{c}\text { LEM } \\
\text { Espanhol }\end{array}$ & $\begin{array}{c}\text { Efetivo há } \\
4 \text { anos }\end{array}$ & - & Espanhol e PD & 20 \\
\hline P1ET8 & $\begin{array}{l}\text { Geografia, } \\
\text { Português e } \\
\text { Espanhol }\end{array}$ & Geografia & $\begin{array}{c}\text { Efetivo há } \\
15 \text { anos }\end{array}$ & $\mathrm{X}$ & Espanhol & 7 \\
\hline
\end{tabular}

Fonte: Autoria própria

Inicialmente, dos 15 professores de Espanhol de Taguatinga, pelo menos 10 são efetivos e 3 são contratos temporários. Dos 10 professores efetivos, os 8 mais antigos na Secretaria de Educação (de 9 a 26 anos) possuem licenciatura dupla em Português e Espanhol, sendo que destes, 5 tem a área de concurso "Língua Portuguesa", 2 são concursadas para "Atividades" e 1 para "Geografia". Conversando com esses professores, o caso de todos é o mesmo: antes de 2010 ministravam aulas de língua portuguesa e geografia há muitos anos. Com a implantação, por possuírem a dupla habilitação (na maioria dos casos, obviamente, também cursada há muitos anos atrás), necessitaram assumir a carga horária de língua espanhola, sendo que a grande maioria destes professores não se sentia preparada para tal, 
uma vez que não ministrava aulas de Espanhol, apenas possuía a dupla habilitação. O que aconteceu com esses docentes Laseca (2008, p. 92) chamou de "reutilização de professores", que seria reconverter um professor de outra disciplina em um professor de Espanhol.

Cabe destacar que os cursos de dupla habilitação atualmente não são autorizados pelo MEC, por não cumprirem a exigência das 2.800 h como mínimo para a obtenção de uma habilitação. Renó, Carvalho e Mesquita (2013, p.154) demonstram que no DF, nas instituições de nível superior que oferecem a dupla habilitação em Português-Espanhol há uma "sobrecarga de disciplinas de Língua Portuguesa em detrimento a Língua Espanhola e o pouco destaque à Literatura Espanhola e Hispano-Americana", reduzindo assim, a formação em Espanhol. As autoras (IBIDEM) ainda afirmam que

\begin{abstract}
Os cursos de Letras com dupla licenciatura, apenas cumpriam a legislação, atendiam a uma necessidade de mercado, porém seus egressos saíam com duas habilitações trabalhadas superficialmente, visto que em seis, sete ou até mesmo oito semestres é impossível aprofundar o conhecimento dos alunos nas duas línguas com suas respectivas literaturas.
\end{abstract}

Nesse sentido, cabe o questionamento acerca da qualidade dessas aulas de Espanhol em Taguatinga, pois, concordo com Maciel (2012, p. 10) quando diz que "essa qualidade está relacionada diretamente aos processos formativos (formação inicial e continuada) de professores nas universidades". Em contrapartida, os outros 2 professores efetivos têm formação específica em Espanhol, foram aprovados no concurso de 2010 (no qual realizaram prova escrita em língua espanhola e inclusive, prova oral), e são os únicos efetivos com a área de concurso "Língua Espanhola". Como a própria professora P3ET5 me disse em conversa informal, “a nossa leva, nós ${ }^{93}$ somos os verdadeiros professores de Espanhol”. Entretanto, o que se vê em Taguatinga são as aulas de Espanhol sendo ministradas por professores de outras disciplinas. A maioria desses 8 professores deseja retornar a lecionar a antiga disciplina. Quanto aos 3 contratos temporários, dois são habilitados somente em Espanhol, e 1 estava aprovado em concurso, porém, por não ter sido convocado, trabalha como contrato temporário em uma vaga que por direito, poderia ser sua ${ }^{94}$.

Em função da reduzida carga horária, o número de turmas desses docentes é de certa forma, descomunal: um docente $20 \mathrm{~h}$ possui de 12 a 16 turmas, ao passo que um de $40 \mathrm{~h}$ chega

\footnotetext{
${ }^{93}$ Neste momento ela se referiu a ela e a mim, uma vez que eu também fui aprovada no concurso para professor efetivo realizado em 2010, porém até este momento ainda aguardo convocação.

${ }^{94}$ Como essa professora, atuei por 3 anos como contrato temporário, mesmo aprovada em concurso para professor efetivo.
} 
a ter 18, 19, 20, 28 turmas de Ensino Médio em uma mesma escola. Somente o professor P1ET8 possui 7 turmas, por atuar em regime de semestralidade.

Além do elevado número de turmas, estes docentes necessitam completar a carga horária com o ensino de outras disciplinas. Dos 15 professores de Taguatinga, apenas 5 ministram somente aulas de Espanhol, 5 ministram aulas de Espanhol e PD, 3 dão aulas de Espanhol, Português ${ }^{95}$ e PD e 1 docente ministra aulas de Espanhol, PD e redação. Por fim, dos 15 docentes de Taguatinga, apenas 5 possuem cursos de pós-graduação.

\subsection{A implantação do Espanhol no Paranoá - DF e a realidade atual}

O Paranoá foi a primeira RA a implantar o Espanhol no DF. No primeiro bimestre de 2014, a RA possuía três escolas oferecendo Ensino Médio, com 3.427 alunos divididos em 88 turmas. Uma ${ }^{96}$ dessas escolas localiza-se em área rural, e, desse modo, minha orientadora e eu decidimos realizar a pesquisa somente nas duas escolas localizadas em área urbana, tendo em vista minha dificuldade para me locomover até a área rural do Paranoá.

A realidade encontrada nesta RA apresenta muitas diferenças em relação à realidade encontrada em Taguatinga.

\subsubsection{EP1}

No dia 02 de abril de 2014 visitei a EP1. No primeiro bimestre de 2014 esta escola tinha 2.163 alunos matriculados, divididos em 54 turmas de Ensino Médio. Esta foi a primeira escola a implantar o Espanhol no ano de 2006, sem o aluno poder optar pelo estudo da língua. A escola apresenta um grande diferencial: Desde 2007 o Espanhol passou a ter duas aulas semanais, pois ganhou um horário antes pertencente ao Ensino Religioso. Hoje a escola atua em regime de semestralidade, logo, a carga horária do Espanhol é de quatro aulas semanais durante um semestre letivo no diurno, e duas aulas semanais no noturno.

A escola possui 5 professores de Espanhol, sendo 3 professores do turno diurno e 2 professores do noturno. Todos são efetivos e têm como área de concurso LEM Espanhol. P1EP1 é licenciada em Espanhol, tem 8 anos na secretaria de Educação e tem pós-graduação. P2PE1 tem 8 anos na Secretaria, tem dupla habilitação em Português e Espanhol e tem pós-

\footnotetext{
${ }^{95}$ Certa vez, ao trabalhar como contrato temporário na Secretaria de Educação do DF, para poder assumir a vaga de Espanhol, mesmo sem habilitação, precisei ministrar aulas de língua portuguesa e PD durante 1 ano.

96 Trata-se de uma escola pequena e de difícil acesso. Essa escola no início de 2014 tinha 351 alunos matriculados no Ensino Médio, divididos em 10 turmas.
} 
graduação. P3EP1 tem 3 anos na Secretaria, pois foi aprovada no concurso de 2010, e não possui pós-graduação. P4EP1 e P5EP1 são professores do noturno, com carga horária de 20h. Licenciados em Português e Espanhol, com área de concurso LEM Espanhol, ministram somente Espanhol em 5 e 6 turmas, respectivamente. Por serem do noturno não os encontrei, tendo obtido essas informações na escola.

A sala de coordenação da EP1 é espaçosa, e disponibiliza aos professores três computadores com acesso à internet, além de rede wi-fi. Os docentes podem reproduzir materiais em escala ilimitada. No que se refere a recursos impressos, há mais ou menos seis anos a escola foi contemplada com um cheque para a feira do livro, e assim, foi efetuada compra de dicionários. A EP1 também possui livros de literatura doados do acervo pessoal dos próprios professores da língua. A escola já participou do projeto "El País nas Escolas", no qual toda semana recebiam exemplares do periódico. Ainda que o projeto tenha acabado, a escola mantém alguns exemplares para uso dos alunos em trabalhos específicos. A EP1 também adquire com frequência gibis em Espanhol que podem ser utilizados para leitura ao término das aulas de Espanhol.

No que se refere aos recursos tecnológicos, a escola também é bem equipada. No pátio de entrada há um relógio digital, um quadro de avisos (também digital) onde passam notícias do ENEM e do PAS. A escola possui laboratório de informática, dois data shows, e o "Cine Mais”, uma sala com estrutura de cinema para os alunos: iluminação baixa, tela grande e cadeiras acolchoadas. Para usar o Cine o professor deve marcar horário. É válido ressaltar que todas as salas de aula possuem televisão de LCD, e que a aula é ambiente.

Finalmente, o Espanhol reprova como qualquer outra disciplina, e apesar de apresentar bons recursos, a escola não possui um projeto relacionado à LEM.

\subsubsection{EP2}

No dia 22 de abril de 2014 visitei a EP2. Trata-se de uma escola pequena, que no primeiro bimestre de 2014 possuía 913 alunos, divididos em 24 turmas. Esta escola oferece Ensino Médio pela manhã e à noite, e Ensino Fundamental pela tarde. No Ensino Fundamental não há oferta de Espanhol.

A escola implantou o Espanhol no ano de 2008, e o aluno não pode escolher em estudar ou não a língua. Desde 2013 a EP2 redirecionou uma aula de PD para Espanhol, assim, a disciplina passou a ter duas aulas semanais. A partir de 2014 a EP2 começou a atuar 
em regime de semestralidade, desse modo, a carga horária de Espanhol, à semelhança da EP1, é de 4 aulas semanais durante um semestre letivo. Porém, no noturno, ainda que se trabalhe com a semestralidade, a carga horária é de duas aulas semanais.

Hoje a EP2 conta com duas professoras de Espanhol, um no matutino e outra no noturno. P1EP2 é efetiva com 13 anos na Secretaria de Educação, tem licenciatura dupla em Português e Espanhol, e possui pós-graduação. Atualmente, dá aulas de Espanhol e PD a seis turmas. P1EP2 é do turno noturno. É efetiva há 1 ano, 20h, licenciada em Espanhol sem pósgraduação, com área de concurso LEM Espanhol. Atualmente ministra Espanhol a 6 turmas.

Na sala de coordenação não há computadores, mas há acesso à internet. Não há materiais na língua espanhola, e o professor pode reproduzir material de forma flexível. No tocante aos recursos impressos, a escola possui dicionários suficientes para os alunos utilizarem em sala e há livros de literatura, porém, traduzidos para o Português. Não há gramáticas, ou livros didáticos, nem jornais ou revistas em Espanhol. A escola possui um laboratório de informática e não há sala de multimídia. Entretanto, a escola tem dois DataShows, aparelhos de som e DVD. Cabe destacar que cada sala de aula é equipada com uma televisão plana. Por fim, o Espanhol na EP2 reprova normalmente, a escola não realiza nenhum projeto relacionado a LEM e a sala não é ambiente.

\subsubsection{O Panorama geral do ensino de Espanhol no Paranoá - DF}

De maneira geral, no que se refere a recursos estruturais e de pessoal, as escolas do Paranoá apresentam uma realidade consideravelmente melhor que a realidade de Taguatinga.

Inicialmente, pela RA ter implantado o Espanhol mais cedo, visto que uma escola implantou em 2006 e a outra em 2008. Isso demonstra que estas escolas não protelaram o prazo da implantação, como fizeram muitas instituições de ensino, uma vez que poucos estados estavam efetivamente preocupados, e empenhados na implantação do Espanhol no Ensino Médio, "algo que precisaria de um planejamento mais diretamente voltado para as necessidades locais, muito variadas, em todos os sentidos, num país das dimensões do nosso" (GONZÁLEZ, 2009).

No tocante a este planejamento, ainda que a EP1 e a EP2 tenham enfrentado problemas estruturais e logísticos por implantar o Espanhol tão próximo ao ano da sanção (2005), nota-se que mudanças foram planejadas e efetuadas pela melhoria do ensino da língua, como por exemplo, a redistribuição de carga horária que ocorreu nas duas instituições 
escolares: o Espanhol na EP1 ganhou uma aula que antes era de ensino religioso e na EP2 ganhou uma aula antes pertencente ao PD. Isso evidencia que essas escolas, seus professores e gestores, perceberam o que Rinaldi (2014, p. 14, grifo meu) constatou ao afirmar que

\begin{abstract}
A segunda questão está relacionada à carga horária dos cursos de línguas, geralmente uma ou duas vezes por semana, o que totaliza, quando muito, 400 minutos por mês. Essa quantidade é mínima para que se possa efetivamente produzir um trabalho de qualidade. Assim, entendemos que é uma necessidade premente o aumento dessa quantidade de horas para que se possa ter um ensino de primeira linha, como proposto nos documentos oficiais.
\end{abstract}

À semelhança de Taguatinga, o aluno não teve opção por não estudar o Espanhol, também por falta de logística. Contudo, ainda hoje os alunos permanecem sem a opção, sendo o estudo de língua espanhola obrigatório. No tocante à sala de coordenação a realidade encontrada no Paranoá foi muito semelhante à de Taguatinga: as duas escolas oferecem rede wi-fi aos professores, entretanto somente uma possui computador.

Em relação aos materiais impressos, a realidade das duas escolas também pode ser considerada melhor: A EP1 possui dicionários, livros, e inclusive, jornais, revistas e gibis em Espanhol, lembrando que os livros de literatura foram doados pelos próprios professores de Espanhol, demonstrando a consciência da importância da leitura em LE e atendendo ao dispositivo dos PCNEM (2000, p. 15), quando este relaciona a leitura e o ensino de LEM ao dizer que "[...] é fundamental que o ensino de Língua Estrangeira seja balizado pela função social desse conhecimento na sociedade brasileira. Tal função está, principalmente, relacionada ao uso que se faz de Língua Estrangeira via leitura". Ainda que com menos recursos, a EP2 possui dicionários e livros de literatura traduzidos, porém ainda faltam gramáticas, livros didáticos e periódicos na língua.

As duas escolas também apresentam boa situação referente a recursos tecnológicos, pois possuem laboratório de informática em uso, disponibilidade de DVD, Datashow e som, merecendo destaque o "Cine Mais" da EP1, (uma sala com estrutura de cinema dentro da própria escola) e o fato das duas escolas apresentarem uma televisão em cada sala de aula, contribuindo para a ideia de que atualmente já não há como dissociar o ensino das novas tecnologias: "não há como imaginar o mundo sem essas tecnologias e, por extensão, as aulas e as escolas sem elas" (BAPTISTA, 2014, p. 25). Portanto, o uso de novas tecnologias tem se tornado uma necessidade tanto para o professor, como para o aluno contemporâneo. 
Assim como em Taguatinga, as duas escolas pesquisadas também deixaram a desejar no quesito "projeto relacionado a LEM", pois nenhuma das escolas pesquisadas no Paranoá possui um projeto específico de línguas estrangeiras. De maneira semelhante, nas duas escolas o Espanhol conta para reprovação, da mesma forma que qualquer outra disciplina.

Em relação aos docentes de Espanhol, a realidade encontrada no Paranoá também foi de certa maneira, melhor, como pode ser visto na seguinte tabela:

Tabela 6 - Professores de Espanhol do Paranoá - DF (2014)

\begin{tabular}{|c|c|c|c|c|c|c|}
\hline Professor & Formação & $\begin{array}{c}\text { Área de } \\
\text { Concurso }\end{array}$ & $\begin{array}{l}\text { Efetivo ou } \\
\text { Cont. }\end{array}$ & Pós - Grad. & Disciplinas & $\begin{array}{c}\mathbf{N}^{\circ} \text { de } \\
\text { Turmas }\end{array}$ \\
\hline P1PE1 & Espanhol & $\begin{array}{c}\text { LEM } \\
\text { Espanhol }\end{array}$ & $\begin{array}{c}\text { Efetiva há } 8 \\
\text { anos }\end{array}$ & $X$ & Espanhol & 6 \\
\hline P2PE1 & $\begin{array}{c}\text { Português e } \\
\text { Espanhol }\end{array}$ & $\begin{array}{c}\text { LEM } \\
\text { Espanhol }\end{array}$ & $\begin{array}{c}\text { Efetiva há } 8 \\
\text { anos }\end{array}$ & $X$ & Espanhol & 6 \\
\hline P3PE1 & Espanhol & $\begin{array}{c}\text { LEM } \\
\text { Espanhol }\end{array}$ & $\begin{array}{c}\text { Efetiva há } 3 \\
\text { anos }\end{array}$ & - & Espanhol & 6 \\
\hline P4PE1 & $\begin{array}{l}\text { Português e } \\
\text { Espanhol }\end{array}$ & $\begin{array}{c}\text { LEM } \\
\text { Espanhol }\end{array}$ & $\begin{array}{c}\text { Efetivo há } 1 \\
\text { ano }\end{array}$ & $?$ & Espanhol & 6 \\
\hline P5PE1 & $\begin{array}{c}\text { Português e } \\
\text { Espanhol }\end{array}$ & $\begin{array}{c}\text { LEM } \\
\text { Espanhol }\end{array}$ & $\begin{array}{c}\text { Efetiva há } 3 \\
\text { anos }\end{array}$ & $?$ & Espanhol & 5 \\
\hline P1PE2 & $\begin{array}{c}\text { Português e } \\
\text { Espanhol }\end{array}$ & $\begin{array}{c}\text { Língua } \\
\text { Portuguesa }\end{array}$ & $\begin{array}{c}\text { Efetiva há } \\
13 \text { anos }\end{array}$ & $X$ & $\begin{array}{c}\text { Espanhol e } \\
\text { PD }\end{array}$ & 6 \\
\hline P2PE2 & Espanhol & $\begin{array}{c}\text { LEM } \\
\text { Espanhol }\end{array}$ & $\begin{array}{c}\text { Efetiva há } 1 \\
\text { ano }\end{array}$ & - & Espanhol & 6 \\
\hline
\end{tabular}

Fonte: Autoria própria

Fazendo a comparação com o quadro de professores de Taguatinga, a realidade do Paranoá no tocante aos docentes da disciplina também se apresenta com melhores condições: todos são professores efetivos e somente um docente não é concursado especificamente para LEM Espanhol. Contudo, à semelhança de Taguatinga, mais da metade dos professores do Paranoá tem licenciatura dupla em Português e Espanhol. No entanto, de maneira positiva, dos sete professores, três possuem pós-graduação.

Pela a carga horária ser maior em função da semestralidade (quatro aulas no diurno e duas no noturno), esses professores possuem bem menos turmas (em média, 6) e à exceção de P1EP2, todos ministram somente aulas de Espanhol. 


\subsection{A ENTREVISTA: CONHECENDO A VISÃO DOS PROFESSORES DE ESPANHOL}

"E o educador? (...) será que alguém lhe concede a palavra ou lhe dá ouvidos?"

(RUBEM ALVES, 1980, p. 13)

O segundo instrumento utilizado para a coleta de dados gerais foi uma entrevista ${ }^{97}$ realizada com os docentes de Espanhol e assistentes administrativos (diretores, coordenadores, bibliotecários) de todas as escolas pesquisadas. Este instrumento contou com 5 perguntas, e visou conhecer melhor o que permeia o pensamento desses professores e assistentes acerca de suas realidades de ensino de Espanhol. As perguntas foram:

Quadro 5 - Perguntas da Entrevista com os docentes e assistentes

1. Em sua visão, por qual/quais motivo(s) o Espanhol foi acrescentado ao currículo das escolas públicas?

2. Como professor, quais as suas satisfações em relação ao ensino de Espanhol em escolas públicas do Distrito Federal?

3. Quais as suas insatisfações (dificuldades) em relação ao ensino de Espanhol em escolas públicas do Distrito Federal? De que maneira essas dificuldades prejudicam o ensinoaprendizagem?

4. Em sua opinião, como seria a realidade ideal de ensino de Espanhol em escolas públicas do Distrito Federal?

5. Que medidas práticas poderiam ser tomadas para a melhoria do ensino de Espanhol em escolas públicas do Distrito Federal?

Fonte: Autoria própria

Optei por realizar essa entrevista com os docentes visto que estes foram os primeiros afetados pela implantação do Espanhol, tiveram e ainda têm papel fundamental nesta implantação. Da mesma forma, desejei incluir os assistentes ${ }^{98}$ uma vez que muitos destes formam a gestão escolar, interferindo de forma direta em decisões importantes relativas ao funcionamento das escolas.

Também é válido salientar que não realizei nenhuma alteração de caráter gramatical nos relatos obtidos, a fim de preservá-los da mesma forma como foram ditos (ou escritos) pelos professores e assistentes entrevistados. Portanto, à luz das considerações feitas, a seguir exponho e discorro acerca dos dados obtidos.

\footnotetext{
97 Esta entrevista encontra-se no Apêndice F, ao final desta dissertação, e foi realizada pessoalmente com a maioria dos professores e assistentes citados nesta pesquisa. Alguns professores me responderam via $e$-mail, e alguns outros (poucos, felizmente) não me responderam.

${ }^{98}$ Lembrando que quando me refiro a assistentes me refiro ao pessoal administrativo das escolas como diretores, coordenadores pedagógicos e bibliotecários.
} 


\subsubsection{Em sua visão, por qual/quais motivo(s) o Espanhol foi acrescentado ao currículo das escolas públicas?}

Através das respostas obtidas, pude perceber que há um consenso em relação a algumas ideias e crenças que permeiam o imaginário dos professores de Espanhol $^{99} \mathrm{e}$ assistentes das escolas no que se refere aos motivos da implantação do Espanhol no Brasil.

Inicialmente, a motivação mais citada foi a criação do MERCOSUL e a tentativa de fortalecimento do Brasil com países cuja língua oficial é o Espanhol:

P2ET2: Eu acho porque o Espanhol tem tido uma importância a mais pro Brasil, devido ao MERCOSUL, devido às empresas multinacionais, ao setor de turismo, de hotelaria (...).

P1ET3: Pela proximidade (fronteira) com os países da língua espanhola e a implantação do MERCOSUL.

P2ET4: (...) pelo acordo, penso eu, do Brasil com o MERCOSUL.

P2ET5: Eu acho que tem a ver com o MERCOSUL, né?

Nas falas acima é possível perceber o que Amaral e Mazzaro (2007, p. 1) constataram ao afirmar que "a principal causa para essa mudança repentina no status da língua espanhola costuma ser atribuída à criação do Mercosul". Como esta pesquisa já demonstrou, o MERCOSUL foi um grande elemento para a integração dos países latino-americanos, contribuindo não somente para o estreitamento dos laços, mas também para a valorização do Espanhol no Brasil (IBIDEM). Contudo, como afirmou Jaeger (2009, p. 31), "a resposta cristalizada pelo senso comum não hesita atribuir à participação do Brasil no Mercosul a razão para esta novidade no sistema educativo". Logo, coincido com o autor quando afirma que essa visão corresponde a um senso comum, visto que muitas outras motivações de várias naturezas (principalmente econômicas/políticas) contribuíram para a inserção do Espanhol nas escolas brasileiras.

Alguns dos outros professores, além de citar a criação do MERCOSUL, enfatizam a proximidade do Brasil como os países que falam Espanhol, e o fato do Brasil ser o único país de língua portuguesa, o que gerou a necessidade de aprender o Espanhol:

\footnotetext{
${ }^{99}$ Nesta pergunta optei por não separar as respostas dos professores de Taguatinga e do Paranoá, visto que meu objetivo com ela foi conhecer o pensamento dos docentes e assistentes administrativos enquanto atores das instituição escolar como um todo. De qualquer modo, cada fala possui a identificação do professor, escola e RA, bem como as cores: preto para os de Taguatinga e azul para os do Paranoá.
} 
P1ET2: (...) por conta dos países que nos rodeiam, né, que falam Espanhol, então na América do Sul nós somos o único pais que fala Português (...).

P1ET8: Quase todos os países da América Latina falam Espanhol e devido à necessidade e cobrança, que hoje o sistema cobra.

A1EP1: (...) Nós temos toda nossa fronteira voltada para os países de língua espanhola, sendo que dentro da América Latina (...) somente nós falamos Português...

P2EP1: (...) eu acho assim, pela expansão do idioma e também pelo Brasil, rodeado de países que tem o Espanhol como idioma oficial.

P3EP1: (...) Participamos do MERCOSUL (...), somos o único país que fala Português dentro do MERCOSUL que "tá” rodeado de, desses países que falam Espanhol...

Portanto, para estes professores a proximidade entre os países da América Latina "cobrou”, gerou a necessidade, de se aprender o Espanhol, visto que é uma língua próxima a nós, não só geograficamente, mas também lexicalmente, como afirmou esta professora do Paranoá:

P1EP1: Primeiro porque... Os países que estão próximos ao Brasil, todos eles falam espanhol. Né... Essa proximidade... Entre fronteiras, né. E depois porque é um língua que é muito parecida com o Português, 85\% do léxico é igual ao Português (...).

Além de citar a proximidade entre o Brasil e países de fala espanhola, uma outra docente do Paranoá encara a implantação do Espanhol nas escolas brasileiras como uma forma de romper a barreira linguística entre os brasileiros e o Espanhol:

P1EP2: Eu acho que pela proximidade dos países da América Latina, porque o Brasil é uma ilha que fala Português, todos os nossos vizinhos falam Espanhol. Nós temos como se fosse um bloqueio cultural. As informações culturais dos países latino-americanos não chegam ao Brasil. As músicas mais tocadas na América Latina, do México e Argentina não são as mais tocadas no Brasil, né.

Por meio da fala acima é possível relembrar a visão de Átila Lira na justificação da Lei 11.161/2005, quando este afirma que "a maioria esmagadora dos países que integram a América Latina é composta por nações hispânicas, que por conseguinte falam o idioma 
espanhol. O Brasil, onde se fala apenas o português, tornou-se uma ilha, neste contexto" (CÂMARA DOS DEPUTADOS, 2000, grifo meu). A fala dessa professora ressalta a existência de um "bloqueio cultural”, pois para ela, não há troca significativa de informações culturais entre o Brasil e os países que têm o Espanhol como língua oficial, contribuindo para o pensamento de que "a inclusão do Espanhol seria a forma do Brasil romper com o isolamento linguístico a que estaria sujeito. Seria a forma de transpor a fronteira da língua que estaria dificultando a maior inserção do Brasil no contexto latino-americano" (CRISTOFOLI, 2012, p. 8).

Alguns professores além de citar o MERCOSUL, concluíram que a implantação se tratou de um ato de interesse do governo, uma jogada política, econômica e de mercado que beneficiaria o Brasil e suas relações, internacionalmente:

P1ET1: Porque o Brasil tem interesses comerciais e políticos com países que falam Espanhol.

P2ET1: Motivos de caráter políticos (...), uma vez que há necessidade de fortalecimento do bloco econômico (...) MERCOSUL, só teria sentido com uma só unidade linguística.

P1E74: Por interesse mesmo, né, de, dessas questões esportivas, porque eu acho que o Brasil infelizmente tem essa visão politica né, da questão do idioma (...), por conta de questões políticas: De ter uma Copa, de ter uma Olimpíada...

P1ET5: Eu acho que foi por causa das relações comerciais que o Brasil tem com a Europa, aqui também, né, com relação à América do Sul, América do Norte.

P3ET5: (...) e não foi "ah, a gente quer investir na educação, vamos colocar mais uma matéria, o Espanhol é extremamente necessário".

P1ET6: (...) por uma questão política. Porque o Brasil precisa se relacionar melhor com o MERCOSUL. (...) E a implantação do Espanhol é importante pra que o Brasil se relacione melhor politicamente, economicamente com a América do Sul e o MERCOSUL.

P1ET7: Eu acredito que foi uma decisão politica do governo porque essa divisa do MERCOSUL é uma tentativa de aproximação (...).

A1EP1: (...) o que veio reforçar essa importância da língua espanhola foi a própria questão do comércio (...), tudo está voltado também, e muito, pra esse lado comercial.

P2EP2: (...) eu não me lembro se foi um acordo politico entre Brasil e Espanha, acho que foi, não foi? Foi o resultado, né? (...) Eu acho que foi meio que uma pressão (...). 
Como é possível ver, muitos professores percebem a ação política por trás da inserção do Espanhol no sistema educativo brasileiro, visto que há necessidade de fortalecimento dos laços, há questões esportivas envolvidas como Copa do Mundo e Olimpíadas, há relações comerciais com a Europa e com os Estados Unidos, contribuindo para o pensamento de Calvet (2007): línguas são escolhas políticas. Dessa maneira, cabe o questionamento levantado por Maciel e Oliveira $(2011$, p. 3) e que também não se cala nesta pesquisa: “A sanção da lei foi mais um ato politico que educacional?".

Ainda que a maioria dos professores tenha atribuído a implantação a questões políticas, alguns professores acreditam que a implantação se deu em função de uma necessidade do aluno de ter outra opção de LEM na escola além do Inglês:

P1ET2: (...) é importante que, até que os alunos tenham uma visão de uma outra língua que não seja o Inglês, porque a gente sabe que muitos tem dificuldades no Inglês (...).

A1ET3: Ah, eu acho que é para o aluno ter mais possibilidades né, abrir um leque maior de conhecimento, porque eu acho que só o Inglês não era suficiente, né (...).

P1ET5: (...) E outro fator muito importante é a questão de oportunidade ao aluno, de não focar só no Inglês, dele ter outras opções, de outras línguas...

P3ET5: Eu acho que é pressão da própria sociedade. Sabe, da... Da necessidade que "tá" surgindo disso, né, porque antigamente quando você falava assim: "eu tenho o Inglês", você já era... O "tal”! Hoje em dia, já, não. Hoje em dia o governo viu que ter o Inglês... $O$ governo não, as pessoas estão vendo que ter o Inglês é só... Um... Algo que você tem que ter... Né... Ai um diferencial que "tá" vindo.

P2EP1: (...), e eu acho que a necessidade, porque antes era só o Inglês, Inglês, e depois não, o Espanhol também é importante, é necessário (...).

Essa concepção do Inglês como língua dominante na escola contribui para a existência do que Ribeiro da Silva (2011) chamou de política "implícita” para a língua inglesa, pois o núcleo dessa política seria o status (social, profissional e acadêmico) que a sociedade atribui a esse idioma, uma vez que grande parte da comunidade escolar acredita que o Inglês é obrigatório no ensino brasileiro, e uma língua que, como disse P3ET5, "você tem que ter".

Atrelada ao aprendizado de Inglês, duas assistentes acrescentaram a "facilidade" para viajar quando se fala o Espanhol, como se vê em: 
A1ET1: Acredito que seja pelo fato (...) da necessidade que as pessoas tenham mesmo, né, de irem pra outros países e o Espanhol você sabe se virar... Né, de qualquer forma, que seria mais assim, entre aspas, considerado mais fácil, digamos assim, que o Inglês.

A2ET4: Então, por exemplo, quando eu viajo, eu falo Inglês, mas quando eu não entendo eu falo assim: "hablas Español?” e eles "hablan”, e aí eu me viro!

Nos fragmentos acima as duas assistentes, ao utilizarem a expressão "se virar", dão a entender que o brasileiro "sabe se virar" em Espanhol dada a proximidade entre as línguas, proximidade esta que cria um estereótipo e expectativa de facilidade na aprendizagem de Espanhol por um brasileiro (GONZÁLEZ, 2010). Entretanto, “jamais devemos pensar que, simplesmente porque sabemos português, podemos compreender espanhol sem maiores problemas" (SEDYCIAS, 2005, p. 40). Ademais, nessas falas as assistentes também veem no Espanhol uma língua de comunicação internacional, ou como constataram Celada e Rodrigues (2005), um passaporte para outros países.

Além das razões apresentadas, alguns professores atribuíram a implantação do Espanhol ao próprio crescimento do idioma e sua importância internacionalmente:

P2ET2: (...) é uma língua que está crescendo bastante não só aqui, mas no mundo, né, está quase sendo a segunda língua mais falada (...).

A2ET4: Eu acho que é porque a língua espanhola é uma língua que tende a crescer na questão da economia, do mundo, da globalização (...). Eu acho que ela é o segundo idioma mais falado, né?

P1ET5: (...) principalmente porque eu acho que um terço da população americana fala Espanhol. Então o Espanhol, acho que, se não me engano, é a segunda língua, né?

P1EP2: (...) E além disso, o Espanhol foi se fortalecendo mundialmente, então ele já é a língua oficial da ONU, da Unesco, da OEA, independente dos EUA, do Brasil e do Canadá, (...) e também da União Europeia.

P3EP1: (...) E, o Brasil "tá", digamos assim, alcançando um nível mais internacional, as pessoas conhecem mais o Brasil e a gente com isso tem que desenvolver a forma de contactar com as pessoas de fora.

De fato, atualmente o Espanhol tem se tornado essencial para "contactar as pessoas de fora". O crescimento do Espanhol bem como a sua importância mundial é inegável: Trata-se 
de um idioma oficial em 21 países, possuindo mais de 332 milhões de falantes como LM, perdendo apenas para o Mandarim. Segundo Sedycias (2005, p. 38), "há mais falantes de espanhol como língua nativa que o inglês”. Atualmente, mais de 500 milhões de pessoas falam Espanhol, sendo - como os próprios professores e assistentes enfatizaram - a "segunda língua" mais falada no mundo ocidental.

\subsubsection{Como professor, quais as suas satisfações em relação ao ensino de Espanhol em escolas públicas do Distrito Federal ${ }^{100}$ ?}

Em Taguatinga, a maior satisfação de muitos professores diz respeito ao interesse dos alunos ao demonstrarem motivação em aprender a língua:

P1ET2: Olha, por enquanto são pouquíssimas (...). Eles gostam de aprender também uma expressão coloquial, eles se animam, eu trago uma música, eles gostam, né, então essas são as pequenas satisfações.

P2ET2: (...) eles gostam, tem muitos que gostam e isso é uma satisfação pra mim.

P1ET5: Eu percebo assim, que tem aluno que gosta né, não sei se é pela similaridade com o Português, ou porque quando eu vou trabalhar com eles eu falo a importância de aprender uma língua, a cultura de um país (...). Então a princípio eu acho que assim, eu procuro motivar, trazer músicas... Principalmente trazer curiosidades.

P2ET5: Minha maior satisfação é a própria curiosidade do aluno, né! Ele... E isso contribui para que a... Para que a aula fique lúdica, né...

P3ET5: Quando o aluno chega e fala que está gostando muito da matéria. Quando eu entro e eles querem, eu falo assim: "boa tarde”, e eles: "buenas tardes, maestra!” (...), querem saber como é que funciona, chega: "ah professora, "tô" adorando Espanhol” (...). O lado bom é quando você vê que um aluno está realmente aprendendo, né... Isso pra mim é o que vale (...). Aí eu não me sinto mais um tampa buraco.

Tendo em vista a realidade apresentada nas escolas de Taguatinga (carga horária ínfima de 50 minutos, e inúmeras turmas), ainda que as satisfações pareçam "pouquíssimas", esses professores se sentem satisfeitos quando seus alunos se animam, têm curiosidade e interesse pelo Espanhol, deixando de se sentirem "tapa buracos" na grade horária.

\footnotetext{
${ }^{100}$ Tendo em vista que o ensino de Espanhol apresenta diversas diferenças entre Taguatinga e Paranoá, a partir desta pergunta constatei a necessidade de apresentar as respostas de cada RA separadamente.
} 
Cabe salientar que alguns professores enfatizam de maneira positiva suas próprias ações, atribuindo destaque ao seu trabalho docente como uma maneira implícita de autovalorização, ao justificar a motivação dos alunos em função de eles, os professores, trabalharem músicas; conhecimentos sobre a cultura, curiosidades da língua, ou seja, a utilização de elementos que contribuem para uma aula mais lúdica.

De fato, concordo com Melo (2013) quando afirma que as atividades lúdicas motivam os alunos a aprender e a engajar-se na língua, lembrando que a motivação é elemento essencial no aprendizado de LE. Logo, perceber motivação nos alunos e ver que eles gostam da disciplina é um fator de grande satisfação para esses professores, ainda que tais evidências sejam constatadas de forma mínima:

P1ET7: Nossa, quando você encontra um aluno interessado, quando você encontra pelo menos um numa turma, um aluno que goste de Espanhol (...), isso é bacana pra gente, então é uma coisa que motiva... Você às vezes encontrar um aluno que "ah, eu gosto de falar", "eu gosto de ouvir música em Espanhol" (...), os meninos falam "ah, eu assisti o Chaves em Espanhol” é uma coisinha boba (...), pequenos detalhes...

É possível identificar a satisfação desse professor quando percebe que há motivação nos alunos nem que seja pelo menos "um aluno interessado", ainda que por meio de uma "coisinha boba" (como assistir um episódio de Chaves ou ouvir uma música), a dizer: pequenos detalhes.

Outra professora fica feliz quando percebe que seus alunos preferem Espanhol ao Inglês e optam pelo Espanhol nas provas do PAS e do ENEM:

P1ET4: Quando eu ouço o aluno falar: eu prefiro o Espanhol do que o Inglês. (...) Quando eles falam "professora, eu escolhi Espanhol lá no PAS e no ENEM", nossa, eu fico muito feliz, porque quando você ouve o aluno falar assim: "odeio Espanhol, prefiro o Inglês", nossa, você fica pensando assim: “não, a nossa língua, uma língua tão próxima, uma língua tão bonita e tão falada, por que que eles preferem [o Inglês]”?

No fragmento acima é notável a experiência identitária da professora, ao passo em que toma para si o Espanhol ao falar "não, a nossa língua", demonstrando tristeza pelo fato do aluno não gostar do Espanhol, a sua língua não somente de trabalho, mas de identificação. 
Para Paiva (2009), identidade abarca várias características sociais e de personalidade, como se pode ver nessa professora: brasileira, com forte ligação à língua espanhola (por ela ser próxima, bonita e muito falada) e que se chateia ao perceber que um aluno não gosta de Espanhol, comprovando a seguinte afirmação: "Então, se você quer mesmo me ferir, fale mal da minha língua." (ANZALDÚA apud HOOKS, 2008, p. 858).

Outros professores se sentem motivados tão somente pela propagação, pela difusão do Espanhol, e por este idioma ter galgado lugar, espaço nas escolas públicas:

P1ET1: Sinto-me satisfeita por poder ver que a língua espanhola está sendo ensinada.

A2ET4: Não sei... Eu acho que a satisfação é assim, que ele [o Espanhol] existe e eu acho importante ele existir. (...) Mas a operalização disso aí é que eu acho que não tá muito legal, né... A satisfação é assim, ele [o Espanhol] está na rede, que bom (...). Então, essa é a satisfação... Agora, te elencar outras, assim, não me vem (...).

A1ET8: (...) eu fico satisfeita no momento em que a gente vê que tem uma coisa nova que é importante, que "tá" no seio da escola e tem lugar né, hoje tem lugar. E a gente espera que essa carga seja ampliada, né, porque vai ser bom pra eles.

É evidente no segundo fragmento que para esta profissional as insatisfações no ensino de Espanhol são maiores que as satisfações, sendo que a mesma não encontra outro motivo de alegria em relação a este ensino, além da língua estar sendo oferecida na grade horária. Já no terceiro fragmento a docente reconhece que nem sempre o Espanhol teve "lugar" na escola, e "torce" para que se aumente a carga, pois "vai ser bom pra eles" - alunos.

Outros professores afirmaram que se sentem satisfeitos quando veem que o aluno dará prosseguimento ao estudo da língua fora da escola:

P1ET2: (...) o nosso tempo é muito corrido, é pouco tempo pra muita coisa, então assim, eles acabam assimilando pouco, né (...), quando a gente percebe que um aluno fala assim: "ah professora, eu faço Espanhol há tantos anos no CILT e depois disso eu quero fazer Espanhol na UnB”, então é uma das poucas satisfações (...).

P2ET2: A minha maior satisfação é saber que, por exemplo, um aluno, ele se interessou para aprender a língua espanhola não só aqui na escola, porque a gente sabe que, por causa, pelo tempo, não dá tempo dele aprender muita coisa (...). 
É relevante notar que essas professoras vinculam o pouco tempo de aulas de Espanhol na escola à necessidade de aprendizado posterior e extracurricular, pois, em função da pouca carga horária, "eles assimilam pouco", não dá tempo do aluno "aprender muita coisa". Nesses fragmentos evidencia-se a crença das professoras de que não é possível aprender LEM em escolas públicas, crença já constatada e confirmada em diversos estudos (ANDRADE, 2004; COELHO, 2005; MIRANDA, 2005; VESZ, 2012).

Por fim, uma professora cita a relação interpessoal entre professor e aluno como o principal elemento de sua satisfação como docente, confirmando a ideia de que "o ensino da Língua Espanhola [...] poderá contribuir para o desenvolvimento cognitivo, emocional, afetivo, social e cognitivo-linguístico" (DIAS, 2014, p. 5, grifo meu):

P1ET6: (...) o aluno tem uma convivência maior, ele tem um carinho maior, então você acaba participando mais da vida do aluno, acaba se tornando conselheiro em muitos casos (...), tem uma troca, tem um carinho (...). Eu venho dar aula, ehh, disposta, e saio ainda mais disposta, porque é gratificante (...). É um retorno né, o professor precisa desses (...) elementos pra fortalecer o seu trabalho, que é um trabalho cansativo (...). Esse tipo de retorno é mais gratificante do que salário, do que condições de trabalho...

Como é possível ver no fragmento acima, P1ET6 fica satisfeita ao se sentir querida por seus alunos, grata e mais disposta, mesmo diante dos desafios da profissão, uma vez que o trabalho docente é "cansativo" e o professor necessita de um retorno do alunado para "fortalecer seu trabalho". Nesse sentido, acerca dos desafios encontrados pelo professor de Espanhol, estes, "lejos de ser insalvables, serán siempre un incentivo para quienes realizan sus trabajos con seriedad y, sobre todo, con pasión. Que de eso se trata. (KULIKOWSKI, 2005, p. 51-52, grifo meu).

Em relação às respostas obtidas no Paranoá, inicio com as que evidenciam de maneira mais clara a diferença entre as realidades de ensino das duas RAs pesquisadas:

P1EP1: (...) o professor, ele tem essa facilidade de ministrar as suas aulas em Espanhol e o aluno entender, lógico que dentro de uma fluência, né, mais, mais lenta (...). Tem essa facilidade do professor conseguir ministrar as aulas na língua alvo.

P2EP1: (...) é porque aqui a gente "tá” (...) numa realidade diferente das outras escolas. Né? Aqui a gente consegue que eles aprendam alguma coisa (...). Se tivesse em outra escola (...), 
às vezes o professor tem 26 turmas (...)... Aí não seria tão otimista quanto aqui, né? (...). A gente consegue alguma coisa (...), algum resultado.

Todos os professores que entrevistei no Paranoá ministram suas aulas em Espanhol, diferentemente de Taguatinga, pois, de acordo com os professores de Taguatinga, ministrar as aulas na língua é inviável, pois não há tempo para sanar dúvidas de vocabulário. Logo, P1EP1 se satisfaz com essa possibilidade, ao passo em que P2EP1 reconhece que a realidade por elas vivenciada é "diferente" das demais escolas, afirmando que em escolas com a realidade encontrada em Taguatinga já não haveria tamanha satisfação nem aprendizagem por parte dos alunos. Assim, mais uma vez é perceptível a crença de que não se aprende idiomas na escola com condições "normais". Contudo, qualidade de ensino e eficácia da aprendizagem, como afirmou Rinaldi (2014, p. 12) são possíveis na escola, e de certa forma, relacionam-se com a carga horária: "é necessário que se desmitifique a ideia de que a aprendizagem de idiomas na escola é ineficaz. Ela é possível, sim, desde que as condições sejam favoráveis. Uma possibilidade seria ampliar a carga horária das línguas estrangeiras”.

Em função da carga horária, alguns docentes do Paranoá têm condições de trabalhar a oralidade de seus alunos, e isso é motivo de grande satisfação:

P3EP1: (...) eu acho fantástico escutar os alunos falando. Eu fico muito feliz quando eles começam a falar. Eu realizo prova oral com eles pra eu escutar também, observar pronunciação, a fluência deles, então quando eu escuto eles falando é fantástico, eu me sinto muito feliz! É,, eu acho principalmente essa parte.

P1EP2: (...) Então tem aluno aqui que narra jogo de futebol igualzinho narrador espanhol! É super lindo, é super emocionante, eu arrepio de lembrar! Né, e aí a gente faz (...) desafio com trava línguas, né, e aí tem um monte que só se enrola, mas sempre tem um, ou dois ou três de cada sala que se destaca né, e fala (...).

Infelizmente, nem todas as realidade de Espanhol propiciam o desenvolvimento da oralidade dos alunos, como é possível para estas professoras do Paranoá. Assim, vê-se a impossibilidade de efetivar na prática a orientação dos PCNEM (2000, p.19, grifo meu): “A aprendizagem de uma LE deve garantir ao aluno seu engajamento discursivo, ou seja, a capacidade de se envolver e envolver outros no discurso". No entanto, como o aluno se 
engajará discursivamente e envolverá outros colegas se a ele é negado o desenvolvimento das habilidades comunicativas?

À semelhança de Taguatinga, os professores do Paranoá também se sentem satisfeitos ao perceberem que os alunos se interessam pela língua espanhola:

P1EP1: Primeiro a aceitação do aluno. Ele quer aprender, ele gosta.

P1EP2: (...) Ou então quando eles se interessam, independente de procurarem um curso particular, eles, eles extrapolam as minhas expectativas.

P2EP2: (...) fico muito satisfeita assim, quando chego em sala (...) que há um interesse, que há uma vontade (...). Eu fico muito feliz quando eu chego e as pessoas querem (...). Eu "tô" sempre disposta, sabe?

Mais uma vez é notável que o interesse dos alunos é um grande fator de motivação para o professor, seja a realidade favorável ao ensino, ou não. Quando o aluno quer aprender, quando ele gosta, o professor se sentirá motivado, e geralmente, "disposto".

No Paranoá, alguns professores citaram como fonte de satisfação o aluno optar pelo Espanhol nas provas do PAS, ENEM e vestibular:

P2EP1: (...) aí a gente às vezes pergunta, né: “quantos fizeram inscrição pro PAS?” Aí tantos, né. "Quanto fizeram inscrição pra Espanhol? Quantos pra Inglês?”, normalmente a maior procura é por Espanhol. (...) 90\%... É, é na faixa de $90 \%$ (...).

P1EP2: Ah, é muito legal. Ano passado eu já estava de licença médica, e os meninos fizeram o ENEM, e eles falaram que o estilo de prova do ENEM era o mesmo raciocínio que eu tinha passado pra eles em sala de aula, aí eu fiquei super orgulhosa!

A2EP2: (...) Acompanhar as avaliações de grande escala (ENEM, vestibular, etc), e poder ter uma opção de idioma a escolher.

Dois assistentes citaram que sua satisfação consiste em perceber que a inclusão do Espanhol na grade curricular foi um grande avanço, e que tal ensino veio para somar:

A1EP1: Ah, a minha satisfação é, é justamente essa questão de que já ouve um avanço. Né? Porque se nós pensarmos aí, há 15, 20 anos atrás, algumas escolas, em algumas unidades da Federação, elas ofereciam até mesmo o Francês, mas não ofereciam o Espanhol. (...). Mais 
uma vez a gente, né, virava as costas para os nossos "Hermanos" e dávamos prioridade, né, para o estudo de outras línguas. (...).

A1EP2: (...) fico feliz do ensino estar ampliando as possibilidades, né, não reduzindo.

A implantação do Espanhol nas escolas brasileiras uniu uma América Latina antes "desintegrada". Logo, "se o passado colonial decretou que o Brasil viveria linguisticamente separado de seus hermanos, como seres colonizados "de costas" um para o outro, os ventos da globalização parecem soprar em variadas direções" (JAEGER, 2009, p. 35), sendo uma dessas variadas direções, a sanção da Lei 11.161/2005 em solo brasileiro.

\subsubsection{Quais as suas insatisfações (dificuldades) em relação ao ensino de Espanhol em escolas públicas do Distrito Federal? De que maneira essas dificuldades prejudicam o ensino-aprendizagem?}

Esta pergunta foi a que obteve maiores respostas em Taguatinga e as menores respostas no Paranoá. A dificuldade mais relatada em Taguatinga apareceu praticamente no início de todas as falas: a pouca carga horária (uma aula semanal de 50 minutos). Como foram muitos relatos, julguei rico expô-los no seguinte quadro:

Quadro 6 - Insatisfação referente à carga horária (Professores de Taguatinga)

\begin{tabular}{|l|l|}
\hline P1ET1 & $\begin{array}{l}\text { A carga horária é muito pequena. O professor não consegue trabalhar a parte oral como } \\
\text { ela deve ser trabalhada. }\end{array}$ \\
\hline P1ET2 & $\begin{array}{l}\text { A maior dificuldade que nós temos é o tempo. (...) É muito difícil você ensinar alguma coisa } \\
\text { em } 45 \text { minutos (...). É uma língua que envolve leitura; envolve oralidade, interpretação de } \\
\text { texto, gramática, a gramatica do Espanhol é pesada, né (...). }\end{array}$ \\
\hline P2ET2 & $\begin{array}{l}\text { (...) Muitas dificuldades. Uma é a questão do tempo. É um horário só pra cada turma, eu } \\
\text { tenho o total de } 28 \text { turmas, e só tem eu de professora do vespertino (...), então a gente tem } \\
\text { todas as turmas e um horário. Então os alunos mal entram na sala e já saem! Então até eles } \\
\text { entrarem, se sentarem, se arrumarem. (...). Tem muitos que levam de qualquer jeito porque } \\
\text { não tem um tempo adequado pra gente estar trabalhando a disciplina... E enfim, a gente } \\
\text { fica cansada porque é um esforço muito... Muito a mais do que os outros professores, né, } \\
\text { porque nós somos considerados anormais aqui na escola (...). }\end{array}$ \\
\hline P1ET3 & $\begin{array}{l}\text { O tempo de aula é insuficiente (45 minutos por semana) para um aprofundamento (...). } \\
\text { A1ET3 }\end{array} \begin{array}{l}\text { A carga horária. Eu acho que é uma carga horária muito reduzida. A professora da tarde } \\
\text { mesmo, ela, assim, se desdobra (...). Então assim, é muito corrido (...). }\end{array}$ \\
\hline P1ET4 & \begin{tabular}{l} 
Primeira, a quantidade (...) de horas. Né, uma aula simples é muito difícil, salas cheias... \\
\hline
\end{tabular} \\
\hline
\end{tabular}




\begin{tabular}{|c|c|}
\hline P2ET4 & $\begin{array}{l}\text { Além da carga reduzida, outro fator é o do pouco interesse da maioria dos alunos que não } \\
\text { levam tão a sério. Ainda veem como uma parte diversificada e não uma disciplina } \\
\text { eliminatória. }\end{array}$ \\
\hline A2ET4 & $\begin{array}{l}\text { (...) a principal dificuldade é o número de turmas que um professor de Espanhol tem que } \\
\text { trabalhar dentro de uma escola. Então, eles trabalham com 16, } 15 \text { turmas, né, de manhã, } \\
\text { 18... Então assim, tem uma carga horária muito pequenininha... (...). Pra ele fazer um bom } \\
\text { trabalho, legal é, é uma... É difícil. (...) Como que esse professor vai fazer? Por mais que } \\
\text { ele queira, é um pouco difícil (...). O aluno vai ficar "noções de Espanhol”. }\end{array}$ \\
\hline P2ET5 & $\begin{array}{l}\text { (...) um fator também muito importante é a questão da hora aula. É uma aula por semana } \\
\text { (...). A hora aula não contribui, não ajuda, né, uma hora aula é muito pouco (...). }\end{array}$ \\
\hline P3ET5 & $\begin{array}{l}\text { (...) eu só tenho } 45 \text { minutos... Por... Por turma (...). Eu tenho 16, } 14 \text { turmas. E não tem } \\
\text { como você puxar muita coisa do aluno. Porque aí assim, às vezes a gente começa a aula } \\
\text { depois do intervalo. Eles nunca entram diretamente depois do intervalo. Já perdi meia hora, } \\
\text { dez minutos da minha aula, minha aula agora tem } 35 \text { minutos (...). E é uma matéria que... A } \\
\text { gramática é muito rica. Então, às vezes assim, começa a ensinar um tempo verbal, eu não } \\
\text { consigo terminar. E aí esse menino vai passar uma semana sem ver aquilo. Se você dando } \\
\text { uma aula hoje e voltar nisso amanhã eles já não se lembram porque eles não estudam, } \\
\text { imagina com uma semana? }\end{array}$ \\
\hline P1ET6 & $\begin{array}{l}\text { (...) a principal é a carga horária. Porque... Eu tenho } 20 \text { turmas e uma aula por semana pra } \\
\text { cada turma. Então, às vezes tem um feriado (...), alguma atividade da escola, e eu perco } \\
\text { essa aula, então o meu aluno fica uma semana sem aula. E aí isso é uma grande } \\
\text { dificuldade, porque eu não consigo evoluir no conteúdo. Às vezes chega o dia da prova e } \\
\text { eu ainda não fechei o meu conteúdo todo. }\end{array}$ \\
\hline P1ET7 & $\begin{array}{l}\text { Acho que o mais difícil pra gente é a falta de aula, né. Você dar uma aula só por semana } \\
\text { pra cada turma é muito difícil, porque, e se acontece alguma coisa? Já aconteceu comigo } \\
\text { de eu ficar em um bimestre inteiro, das dez aulas que eu deveria ter dado, eu ter dado } \\
\text { somente quatro. Você entrar em sala quatro vezes só, né, porque acontece alguma coisa às } \\
\text { vezes (...) de não ter aula, uma paralização nossa, uma falta de luz na escola, qualquer } \\
\text { coisa é motivo pra você parar uma aula, se eu tenho uma aula por semana só, perdeu, } \\
\text { acabou a semana pra mim (...). Se o professor chega insatisfeito em sala de aula, acaba que } \\
\text { (...) isso passa pro aluno, o aluno também fica sem vontade, sem disposição pra aprender, } \\
\text { isso é muito ruim. }\end{array}$ \\
\hline A1ET8 & $\begin{array}{l}\text { (...) uma delas é a carga reduzida, né, essa é uma dificuldade. Porque, se o aluno tem um } \\
\text { número menor de aulas, ele não precisa dar tanto valor como ele da às outras que tem bem } \\
\text { mais aulas. }\end{array}$ \\
\hline
\end{tabular}

Fonte: autoria própria

De acordo com os relatos acima, a carga horária não só dificulta o trabalho dos professores de Taguatinga, mas também prejudica a aprendizagem do aluno, dado o pouco 
contato com a língua. Assim, ao invés de o aluno ter um aprendizado eficaz, fica na base de "noções de Espanhol".

A parte oral dificilmente é trabalhada, sendo o aluno privado de desenvolver suas habilidades comunicativas na LE. Tais evidências são paradoxais, pois "se entende que a escola é o espaço mais propício para oferecer oportunidades de aprendizado aos alunos" (MACIEL e OLIVEIRA, 2011, p.1). Contudo, nos casos acima relatados, ao invés de oferecer oportunidades, a própria escola tem privado seus alunos de um aprendizado mais efetivo. Nesse sentido, coincido com Rinaldi (2014, p. 14, grifo meu) quando afirma que estudar uma LE é possível se o trabalho do professor "for voltado ao desenvolvimento das habilidades comunicativas: interação por escrito e oralmente, entendida tanto como capacidade de compreensão, quanto de produção de textos, orais e escritos”. Nisso, é evidente que não há como o professor desenvolver as "tradicionais formas de manifestação da linguagem", antes conhecidas como as quatro habilidades: compreensão escrita e oral, expressão escrita e oral. Nesse pensamento, em concordância com Viñal Júnior (2012b, p. 11, grifo meu), percebo que

\begin{abstract}
Las cuatro habilidades en la enseñanza de lenguas extranjeras son de suma importancia para estos estudiantes y su acceso no puede ser robado o impedido en nombre de las dificultades estructurales, personales, económicas o políticas sufridas por la educación brasileña ${ }^{101}$.
\end{abstract}

Ainda à luz desta discussão, alguns docentes enfatizam que não têm condições de trabalhar a "gramática" como deveriam. Ainda que a gramática não seja "a única que deve ter lugar na aula de língua estrangeira, nem deve ser o eixo do curso" (MEC/SEB, 2006, p. 144), o conhecimento gramatical é necessário em classes de LEM, pois leva o estudante a ter a capacidade de produzir enunciados, sendo esta capacidade mais do que uma simples conjugação verbal (IBIDEM). Todavia, além de não ser possível desenvolver a prática oral do discurso, o conhecimento gramatical do aluno também se torna defasado. Logo, como trabalhar o Espanhol com qualidade máxima e sem reducionismos como afirmam as OCENS? tendo em vista as condições acima relatadas? Tais condições de ensino contribuem não só para as cláusulas imaginárias (CELADA e RODRIGUES, 2005) que permeiam o pensamento do aluno brasileiro (facilidade da língua, língua que dispensa estudo formal, etc), mas também para a não valorização da disciplina, uma vez que muitos alunos ainda vêm na disciplina uma

\footnotetext{
101 “As quatro habilidades no ensino de línguas estrangeiras são de suma importância para estes estudantes e o seu acesso não pode ser roubado ou impedido em nome das dificuldades estruturais, pessoais, econômicas ou políticas sofridas pela educação brasileira".
} 
matéria que não reprova, que pode "ser levada de qualquer forma". Quanto ao professor de Espanhol, este "se desdobra" com sua infinidade de turmas, tendo um esforço muito além de seus limites, sendo muitas vezes visto como "anormal".

Infelizmente, constatei em alguns desses professores um ensino "facilitado da língua", não somente em função da carga horária, mas do próprio desinteresse do aluno que, frequentemente, não vê no Espanhol uma disciplina com a qual "deva se preocupar". Segundo Vesz (2012) este ensino facilitado abarca a simples listagem de palavras ou a mera comparação das diferenças lexicais entre o Português e o Espanhol. Nisso, evidencia-se a “ideologia do pouquinho" (SANTOS, L., 2005), a saber: o ensino de poucas palavras, de uma base mínima de fragmentos da língua estudada, visto que para o professor, o aluno não teria condições de assimilar estruturas complexas da língua, criando o que Coelho (2006) julgou ser um verdadeiro círculo vicioso, ao dizer que "os professores não ensinam coisas mais desafiadoras porque acreditam que os alunos não estão interessados em aprender, e porque eles não ensinam coisas desafiadoras os alunos não mostram interesse e motivação" (COELHO, 2006, p. 133, apud VESZ, 2012, p. 67).

Cabe destacar que os alunos também percebem a insuficiência da carga horária de uma aula semanal, pois questionam e reclamam das poucas aulas de Espanhol:

P3ET5: (...) e eles mesmos falam: "ah não professora, uma aula só?”.

P2ET2: (...) e a aula passa tão rápido que eles ficam insatisfeitos (...). E aí eles perguntam pra mim: "por que não pode ser dois horários de Espanhol e tem que ser dois de Inglês?”.

P1ET6: (...) alguns alunos já chegaram pra mim e falaram: "poxa, professora, nós poderíamos ter duas aulas de Espanhol por semana” (...), eles percebem a necessidade.

Ademais, algumas professoras citam como insatisfação a falta de "pré-requisito" do aluno na LM, ou seja, o desconhecimento do funcionamento do Português, uma vez que o conhecimento prévio da LM "auxiliará o aprendiz a compreender o idioma estrangeiro" (MEC/SEB, 2006, p. 142):

P2ET5: (...) a falta de pré-requisito dos alunos na língua portuguesa... (...), ela dificulta o aprendizado do próprio Espanhol (...). Então você tem que voltar, você tem que trabalhar (...). A minha parte de insatisfação é essa. 
P3ET5: (...) Eu falo "gente, me dá um exemplo de um verbo no infinitivo", e eles nãos sabem me dizer (...). Um dia desses uma menina falou que sopa era verbo (...). Aí outro virou pra ela e falou assim: "sopa é verbo? Como é que é, eu sopo, você sopa?” (...).

Por fim, alguns docentes citam a escassez de material didático para uso nas aulas de Espanhol. Sobre isso, alguns profissionais das bibliotecas das escolas de Taguatinga afirmaram quem:

A2ET3: Não temos jornais nem em Português, que dirá em Espanhol.

A1ET4: Ixi, se fosse em Inglês tinha um monte... Mas Espanhol não tem quase nada.

A1ET5: Pode por aí: precariedade total.

A1ET7: Os alunos procuram [material em Espanhol], mas não tem...

Dos professores entrevistados no Paranoá, diferentemente de Taguatinga, nenhum citou a carga horária como uma insatisfação. A insatisfação mais citada foi a escassez de material e a falta de estrutura das escolas:

P1EP1: (...) materiais, né, que hoje em dia a gente "tá" tendo tecnologia (...) e a gente não tem essa facilidade de trabalhar com as tecnologias em sala de aula, por falta de recursos.

P2EP1: (...) essa nossa escola, ela não tem uma estrutura de Ensino Médio, foi colocado aqui, foi ficando, então assim, outro dia mesmo, não tinha cadeira suficiente "pros" alunos nas salas (...). Essas coisas deixam a gente, assim... Desanimados às vezes.

P3EP1: (...) a questão de material também. Aqui na escola a gente busca, a gente troca material, a P1EP1, A P2EP1 e eu, mesmo assim é a estrutura mesmo da escola em si, eu queria uma sala toda equipada, com material (...).

P1EP2: Olha, melhorou bastante. As minhas insatisfações diminuíram (...) pelo fato de eu estar trabalhando com uma carga horária maior. Né, mas ainda faltam algumas coisas na escola. Às vezes (...) nenhum aparelho de som funciona, eu não posso contar sempre com o aparelho de som da escola... Não há dicionários de boa qualidade pra trabalhar em sala de aula (...).

A1EP2: (...) o que eu tenho percebido é a questão do, do material didático, os professores reclamam dos materiais didáticos que eles têm disponível (...). 
Como pode ser visto, embora a carga horária tenha aumentado e isso tenha gerado benefícios para os professores e alunos do Paranoá, ainda existem dificuldades no tocante a estrutura, falta de recursos e materiais didáticos, visto que essas escolas do Paranoá ainda têm carência de materiais impressos (como livros e dicionários), recursos tecnológicos e estruturais. Logo, de nada adianta a criação de uma política educacional se posteriormente não houver subsídios para sua prática efetiva, uma vez que "a educação pública depende dos recursos ofertados pelo estado para que possa atender as necessidades existentes" (MACIEL e OLIVEIRA, 2011, p. 4).

Dessa maneira, o professor e o aluno de Espanhol da escola pública no DF têm vivido as implicações da sanção da Lei 11.161/2005: uma lei sancionada com objetivos políticos e fins econômicos, e que se esqueceu de atender às verdadeiras demandas educacionais do aluno brasileiro. Assim, como elucidou Leffa (2005, p. 207, grifo meu), “não nos damos conta de que estamos ausentes, sem voz e sem voto, quando a lei é sancionada, mas presentes, arcando com as consequências quando a lei é aplicada".

Além da falta de recursos e estrutura, algumas professoras citam como insatisfação o elevado número de alunos em suas aulas de Espanhol:

P1EP1: Aqui na escola o número de alunos (...). Uma língua você tem que ter um número reduzido de alunos pra que você possa dar uma atenção individualizada a cada um. Agora, um grupo com 40, 45 alunos, que atenção individualizada você vai dar?

P3EP1: E, a primeira questão que eu acho complicado... Que (...) trás certa dificuldade pra trabalhar é a questão do número de alunos por sala (...). Nunca chegou a 40, mas passa os 35 (...), pra uma sala de idiomas é muito... Essa é a principal questão, porque eu como gosto de trabalhar a parte de conversação, eu sinto que às vezes eu perco muito tempo (...). Então a quantidade de alunos é um fator que prejudica muito.

Para essas professoras o número de alunos é uma grande insatisfação, pois é inviável dar atenção individualizada. Não somente isso, a conversação em sala também é prejudicada, pois demanda muito tempo da aula, tempo este que poderia ser aproveitado em outras atividades com menos alunos.

Para dois assistentes a insatisfação em relação ao ensino de Espanhol está relacionada à não oferta do Espanhol no Ensino Fundamental: 
A1EP1: (...) eh, o ensino do Espanhol na escola pública (...), eu acho que ele deveria começar desde o Ensino Fundamental.

A2EP2: O contato do aluno só ser no Ensino Médio. Não interesse do aluno devido ao contato tardio com o idioma.

É válido ressaltar que o DF tem infringido a lei distrital no 3.694 de 2005, na qual se firma que os estabelecimentos de ensino do Distrito Federal são obrigados a oferecer o Espanhol como opção de LE aos alunos do Ensino Fundamental e Médio. Esse contato tardio, como elucidou A2EP2, pode justificar o desinteresse do aluno em aprender a língua.

Por fim, uma professora, ao falar de sua insatisfação disse o seguinte:

P2EP2: (...) eu "tô" sentindo uma dificuldade (...) lembrando lá da faculdade (...), eu fico achando que faltou muito lá... Entendeu? Faltou muito lá que agora "tá” me fazendo falta (...). Eu acho que seria interessante se tivesse mais oportunidade de formação, sabe? Formação... Formação, formação, formação. Pro professor.

Sabe-se que a formação de professores e sua problemática têm sido amplamente discutidas na LA contemporânea, uma vez que muitos problemas da prática educacional nascem de lacunas na formação inicial. Contudo, infelizmente ainda há muitos cursos de licenciatura que deixam a desejar, abrindo inúmeras lacunas na formação do futuro docente e consequentemente, prejudicando o ensino do Espanhol, como bem afirmou Fernández (2010, p. 75)

[...] hay que considerar que no siempre los cursos de formación de profesores de Español [...] tratan con el necesário detenimiento y profundidad cuestiones relacionadas a la adquisición y aprendizaje de idiomas, teorías linguísticas, enfoques y métodos de enzeñanza, papel del professor, del alumno y de los materiales, etc. [...]. Una de las consecuencias posibles es que no se logren los objetivos pretendidos. ${ }^{102}$

102 “[...] há que considerar que nem sempre os cursos de formação de professores de Espanhol tratam com o necessário cuidado e profundidade questões relacionadas à aquisição e à aprendizagem de idiomas, às teorias linguísticas, aos enfoques e métodos de ensino, ao papel do professor, do aluno e dos materiais, etc. Uma das consequências possíveis é que não se alcancem os objetivos pretendidos”. 
À luz das insatisfações apresentadas pelos profissionais de Taguatinga e do Paranoá, o que se percebe é que a implantação do Espanhol tem carência de qualidade e ainda possui inúmeras necessidades e descompassos.

Vê-se que "as necessidades dos alunos brasileiros estão sendo desrespeitadas em nome de interesses de ordem econômica e política. Observamos que muitos são os beneficiados: centros, editoras, cursos, governos, comércio entre outros” (VINÃL JÚNIOR, 2012, p. 15), menos o aluno e o professor, os primeiros atingidos pela implantação do Espanhol.

Dessa forma, com base nesses descompassos, dificuldades e carências identificados no ensino de Espanhol, percebo que a qualidade e legítima efetivação desse ensino exigem medidas e mudanças reais, ou seja, "um processo novo", como disse Aline Oliveira (2010, p. 56 , grifo meu) ao dizer que

\footnotetext{
Essas questões nos incomodam e nos inquietam, porque o simples fato de sugerir um ensino de qualidade não colabora para a sua efetivação. Pois, os fatos demonstram que a realidade para o ensino de língua estrangeira poderia ser resolvida com posturas também imperativas de concretização de um processo novo.
}

De fato, um processo novo: de conscientização, mudança e valorização da língua espanhola como componente curricular, para que a qualidade deste ensino não seja apenas sugerida, mas efetivada nas escolas púbicas brasileiras.

\subsubsection{Em sua opinião, como seria a realidade ideal de ensino de Espanhol em escolas públicas do Distrito Federal?}

Em Taguatinga, a realidade ideal do ensino de Espanhol para muitos professores seria o aumento da carga horária: pelo menos, duas aulas semanais:

P1ET1: Pelo menos duas aulas para que em uma trabalhássemos a parte gramatical e a outra a parte oral.

P1ET2: (...) que nós tivéssemos pelo menos duas aulas, como o Inglês.

P2ET2: Pelo menos que ficasse com a carga horária junto com a do Inglês, né.

A1ET3: Eu acho que a carga deveria ser a mesma de Português (...). Pra não ficar só esse “faz de conta”. Porque uma aula por semana não prepara o aluno para o vestibular (...), não dá muitas opções (...). Ele sai daqui com "noções”. 
P3ET5: Pelo menos duas aulas... Por semana.

P1ET6: (...) uma carga horária bem maior (...). Três aulas por semana, quatro aulas por semana... Poderia ser ideal (...). Eu poderia trabalhar com mais material, e aí sim, com um livro escrito no idioma ou vídeos no idioma, filmes no idioma, pra que o aluno pudesse praticar a oralidade, porque hoje eu não tenho tempo de praticar a oralidade.

P1ET7: (...) a gente teria que ter no mínimo duas aulas semanais (...).

P1ET8: Pelo menos duas aulas por semana (...).

É relevante destacar que desses professores, quase todos utilizaram a expressão "pelo menos", indicando que o aumento da carga horária seria o mínimo para que se pudesse alcançar uma realidade ideal de ensino de Espanhol em Taguatinga. Também se percebe o desejo de igualar o Espanhol ao Inglês, onde é possível recordar o PL no 4606/1958 ${ }^{103}$ de Juscelino Kubitscheck, no qual se pretendia que o ensino de Espanhol observasse as mesmas bases estabelecidas para o ensino de Inglês. Entendo que essas falas onde se expressa o desejo de "equiparação" ao Inglês, demonstram as marcas do processo histórico que impôs a hegemonia do Inglês como "a língua estrangeira moderna" das escolas brasileiras (CELADA, 2002), sendo este desejo não somente um anseio por aumento de carga horária, mas também um pedido intrínseco de valorização do Espanhol como uma língua veicular, como o Inglês.

De fato, é necessário observar que a grande maioria dos professores não acredita ser possível um ensino efetivo com esta carga horária, sendo este ensino transformado em um verdadeiro "faz de conta". GONZÁLEZ (2009, grifo meu) previu que isso aconteceria caso não se primasse pela qualidade do ensino de Espanhol ao dizer que

\begin{abstract}
A qualidade, não o mercado ou outras razões de ordem externa, lembremos, é a condição de sobrevivência do ensino do espanhol, assim se afirma também nas OCEM. Se não o fizermos dessa forma, [...] entraremos num mundo de faz de conta (os professores fazem de conta que ensinam e os alunos fazem de conta que aprendem, ouve-se com muita frequência) [...].
\end{abstract}

Logo, o que se percebe é o "faz de conta" traçado pela autora, pois o Espanhol não tem sido ensinado em sua totalidade, não têm sido abarcadas todas as dimensões da língua, dessa maneira, o aluno não tem caminhado para um ensino integral do idioma, ficando inclusive com lacunas em sua preparação para o mundo adulto.

\footnotetext{
${ }^{103}$ Convém lembrar que este PL foi analisado no Capítulo Teórico desta dissertação, na página 53.
} 
Assim, entro em conformidade com Reatto e Bissaco (2007, p. 9) quando afirmam que "três anos de uma carga horária reduzida é insuficiente para preparar alunos para o mercado de trabalho ou para responder às expectativas satisfatórias do exame de seleção em língua estrangeira para ingresso nas universidades”. Não há o mínimo de preparação para o aluno, sendo o aluno da escola pública, em sua maioria pertencente às classes menos favorecidas, mais uma vez prejudicado (VIÑAL JÚNIOR, 2012a).

Alguns professores sugerem que não se prive do aluno o direito de escolher estudar o Espanhol, pois, caso os alunos pudessem optar, a realidade poderia ser melhor:

P2ET1: Por que ao invés de serem oferecidas aos alunos duas aulas de Inglês e uma de Espanhol, não se deixa a opção de escolha da língua desejada com (...) três aulas?

P2ET2: (...) ou de repente o aluno optasse por uma língua e ele quisesse estudar aquilo que ele quer, né, porque a gente tem que visar o que o aluno quer, né...

P3ET5: (...) o aluno poderia escolher entre Inglês ou Espanhol. Ou até os dois. Poderia ser, desde que ele quisesse estar ali. Sabe?

Nas falas acima noto o desejo dos professores de trabalharem com alunos que realmente queiram aprender o Espanhol, uma vez que, na prática efetiva de seu dia a dia escolar, "estes profissionais operam com grupos de pessoas cujos interesses são conflitantes e que, geralmente, estão em sala contra sua vontade, e cuja motivação flutua" (BRUMFIT, 1995, p. 36). Por fim, o dispositivo da Lei 11.161/2005 que faculta a matrícula ao aluno deveria ser cumprido, uma vez que este é (ou deveria ser) o ator principal da escola, aquele a quem se deveria querer beneficiar de maneira primária.

Outros professores enfatizam a necessidade de reduzir o número de alunos para melhor atendê-los e melhor trabalhar o idioma em sala de aula:

P1ET3: Menor número de alunos em sala e maior tempo de aula por semana.

P1ET4: (...) infelizmente reduzir a quantidade de alunos (...). A quantidade de aluno e a quantidade da hora-aula eu acho que é o principal.

P2ET4: (...) realidade ideal não se restringe ao Espanhol. Essa matéria sofre o mesmo que as demais: salas muito cheias (agravante, claro, para estudo de um idioma) (...).

P1ET7: (...) turmas menores, “tá”, que a gente pudesse trabalhar mais o idioma em si (...) pra gente poder, sabe, dar uma atenção maior pro aluno. Com turmas muito grandes você 
não consegue ir direto no aluno, não tem como fazer uma atividade de repetição, não tem como eu cobrar melhor do aluno com uma turma muito grande (...).

P1ET8: (...) número reduzido de alunos em sala, no máximo, vinte.

Dada a realidade da escola pública brasileira, sabe-se que a questão do número de alunos não se restringe ao ensino de idiomas e não advém de hoje, visto que problemas na educação pública são antigos, como Moita Lopes já havia concluído há 27 anos: "É claro que não é só este campo [de LEM] que necessita de mudanças imediatas, pois o fracasso da escola pública em todas as disciplinas é mais do que patente" (MOITA LOPES, 1986, p. 99). As duras palavras do autor demonstram que há quase 30 anos atrás o ensino na escola pública já enfrentava dificuldades, como por exemplo, salas cheias e aprendizagem comprometida. Infelizmente, hoje pouca coisa mudou.

Por fim, no que tange à realidade ideal do ensino de Espanhol, alguns docentes citam a formação do professor de Espanhol:

A1ET1: (...) Se não houver também a formação necessária para o professor, seria outro fator de complicação, né, como a gente tem aí, professores que não são habilitados para o idioma... E que estão dentro de sala de aula passando, repassando informação para o aluno. Então, por mais que o aluno queira também, por mais que ele seja interessado, ele não vai conseguir aprender muita coisa.

P1ET5: (...) tem que se oportunizar o professor, ehh, ou fazer uma parceria com a UnB pra "tá" reciclando, porque às vezes o professor, ele tem a formação, mas ele tem que ficar pagando, por fora (...) tem que desembolsar pra fazer essa reciclagem (...), professor não podia pagar, tinha que ser a própria Secretaria pagar para o investimento do professor...

A1ET8: (...) a formação dos profissionais, né? Porque eu acho que tem escola que não deve ter o profissional, que tem falta, a gente ainda percebe muito a falta de profissionais, né, nessa área, tem gente que leva de qualquer jeito, não dá o devido valor, então nesse sentido deveria ser a capacitação dos profissionais (...).

Como é possível ver, as professoras reconhecem a importância da formação do professor de Espanhol. Infelizmente, relembrando o quadro de professores de Taguatinga, não parece importante a formação para dar aulas de Espanhol (CAMARGO, 2004), já que a maioria desses professores atuava há mais ou menos vinte anos na Secretaria de Educação ministrando aulas de outras disciplinas e nunca haviam, efetivamente, dado aulas de 
Espanhol. A exemplo disso, se tem observado em cursos particulares o marketing de aulas com nativos do idioma, entretanto, indivíduos não docentes e sem formação. Tal ato deve ser "visto criticamente ao se questionar justamente a sua formação e devida habilitação para a docência" (REATTO e BISSACO, 2007, p. 6). Outro ponto é a necessidade que estas professoras veem de cursos de formação continuada, uma vez que falta nesses professores criticidade e muitas vezes, conscientização política em relação aos problemas sociais inerentes à linguagem na prática social. Assim, ainda persiste em nós, docentes, o desejo de que a "reciclagem seja uma prática constante em nossas escolas, fazendo com que os professores desenvolvam uma atitude crítica em relação ao seu trabalho. Essa reciclagem é de responsabilidade do Estado e das universidades brasileiras" (MOITA LOPES, 1986, p. 101).

A visão de realidade ideal apresentada pelos professores do Paranoá apresentou-se de certa forma, diferente do ideal dos professores de Taguatinga. A única semelhança é o desejo de redução do número de alunos:

P1EP1: Um número menor de alunos, acho que até 15 alunos seria o ideal, né, que é um Centro de línguas (...), que é o que o Centro de línguas prioriza (...).

P2EP1: O nosso, ele "tá" perto do ideal, porque a única coisa que eu vejo aqui (...) é a quantidade de alunos em sala, porque pra mim teria que ser uma quantidade menor pra gente poder atingir um objetivo maior (...). Já temos o livro, já, temos (...) tempo bom pra trabalhar... Então assim, o que falta mesmo é o número de alunos ser menor.

P3EP1: Seria muito próxima ao que é um Centro de línguas (...) com um número de alunos reduzido ou uma turma... Eu sempre falo que “ahh, no máximo 15" dentro da realidade da escola pública, mas... Eu queria 5 alunos (...) em cada sala!

Convém destacar que segundo P2EP1, a realidade dessas professoras já está próxima do ideal, uma vez que já têm material e tempo "bom para trabalhar", sendo o "único" problema o elevado número de alunos. De fato, tanto as escolas de Taguatinga como as do Paranoá apresentaram a problemática de turmas cheias. Vale lembrar que o Art. 25 da LDB/96 diz que "será objetivo permanente das autoridades responsáveis alcançar relação adequada entre o número de alunos e o professor, a carga horária e as condições materiais do estabelecimento" (BRASIL, 1996, grifo meu). Infelizmente mais uma vez as palavras ficam no papel. 
Nas falas acima também se vê a comparação explícita com a realidade dos Centros de Línguas, sendo que a professora P3EP1 chega a afirmar que gostaria de ter apenas 5 alunos.

Um segundo fator que evidencia a realidade ideal dos professores do Paranoá seria ter mais recursos e a possibilidade de utilizar as tecnologias em sala de aula:

P1EP1: (...) uma sala de aula que tivesse uma lousa digital, que tivesse internet, que a gente pudesse trabalhar com as tecnologias em sala de aula (...). Na verdade a gente tem hoje uma sala de aula do século 19 (...), e o nosso aluno não é mais o aluno do século 19. Né? Então a gente tem uma sala de aula do século 19, professores do século 20 e alunos do século 21! Em que momento eles se encontram? Em nenhum!

P2EP1: (...) claro que acrescentar é sempre bom, né? Por exemplo, um quadro digital, essas coisas todas, a tecnologia sempre ajuda, se tivesse uma videoteca, uma coisa assim, que passa filme "pros” meninos, uma biblioteca mais equipada, ajudaria mais, né?

P3EP1: (...) poder utilizar as TICS aqui também (...).

P2EP2: (...) Seria muito bom se a gente pudesse ter em todas as escolas, pudesse ter sala temática, sabe? A sala temática seria maravilhosa, sabe? Porque aí você poderia deixar a sala já organizada com tudo (...), seria maravilhoso também se pudesse ter toda questão informatizada (...). Seria um sonho, seria ótimo... Multimídia...

A1EP2: As mídias audiovisuais ajudam bastante, eu acho que no ensino de línguas em geral e (...) da língua espanhola (...), material didático, né, disponibilizar áudio e vídeo, né, essa disponibilidade, e uma carga horária um pouco maior (...).

Realmente, não há como negar o desenvolvimento das tecnologias e a necessidade de seu uso no contexto escolar. A informatização nas escolas iniciou nos anos 80, com o surgimento dos primeiros computadores. Nos anos 90 os computadores foram introduzidos para uso exclusivo dos professores, e, em seguida, foram criadas aulas de computação e informática para os alunos (BAPTISTA, 2014). Desde então, a tecnologia avança a largos passos, tornando-se uma verdadeira necessidade. Nesse sentido apoio-me em Baptista (IBIDEM, p. 25, grifo meu) quando afirma que

É importante garantir, no contexto escolar, o acesso às tecnologias disponíveis que permitam ao estudante ampliar suas interações com os objetos de conhecimento, pois o ensino de Língua Espanhola na escola não pode estar ancorado em metodologias do século XIX, quando nossos alunos (nativos digitais) estão em pleno século XXI. 
A autora ainda afirma (IBIDEM, p. 27) que o uso das tecnologias além de ampliar a interação do aluno com a língua estudada, também amplia o conceito das quatro habilidades: “[...] os artefatos tecnológicos permitem diferentes práticas de leitura, escrita, fala e compreensão auditiva, de forma que ampliam consideravelmente o próprio conceito de quatro habilidades (falar, ler, escrever e ouvir)", habilidades estas que devem ser trabalhadas nas aulas de LE para que o ensino seja de fato, integral. Cabe destacar que a professora P2EP2 deseja ter uma sala temática com o material necessário para suas aulas, e que A1EP2 ainda acredita que a carga horária da disciplina é insuficiente, visto que em sua escola o professor de Espanhol ainda utiliza aulas de PD.

Ademais, um assistente e um docente creem que a realidade ideal do ensino de Espanhol seja a implementação do Espanhol no Ensino Fundamental:

A1EP1: (...) mudar o currículo para abranger desde o Ensino Fundamental, né, até o Ensino Médio com uma carga horária compatível, né, pra que (...) nossos alunos pudessem ter um contato com a língua de uma forma mais... Eficiente.

P1EP2: (...) e com o tempo pensar na implantação do Espanhol pro Ensino Fundamental. Porque os manuais que a gente usa, eles começam do alfabeto, né, numerais, coisas simples, mas é como se o aluno já tivesse conhecimento de Espanhol no Ensino Fundamental.

Um ponto identificado acima é o fato dos manuais (livros didáticos) situarem o aluno como alguém que já possui um conhecimento prévio do idioma, o que nem sempre ocorre, pois muitos chegam ao Ensino Médio sem ter tido contato algum com o Espanhol.

Mais uma vez um assistente ressalta a necessidade de "uma carga horária compatível", pois, ainda que estas escolas tenham quatro aulas de Espanhol no diurno e duas no noturno, tal carga horária se deve à semestralidade e ao uso de horários de outras disciplinas:

A1EP2: (...) ter uma carga igual à de Inglês... Né, pelo menos (...). Aqui na escola a gente consegue, ehh, usando o projeto né (...), parte diversificada, que a ideia é aliar (...) a cultura do mundo espanhol, junto com a disciplina de Espanhol.

É evidente que na escola de A1EP2 percebeu-se a necessidade de também trabalhar a “cultura do mundo espanhol”. Sobre isso, coincido com DIAS (2014, p. 7) quando afirma que para o aluno será muito importante "desenvolver o conhecimento relativo aos países em que 
se fala a língua espanhola e o conhecimento das diferentes sociedades e culturas referentes à vida diária desses indivíduos, seus valores, crenças, comportamentos, convenções e usos sociais". Infelizmente nem todas as escolas têm possibilidade e condições de trabalhar a cultura dos países hispano-falantes durante as aulas de Espanhol em função de inúmeros motivos tais como carga horária reduzida e falta de materiais.

Por fim, à semelhança de Taguatinga, uma professora julgou ideal o aluno optar por estudar o Espanhol, uma vez que este ainda pode escolher a LE nas provas seletivas:

P1EP2: (...) E ser opcional. Enquanto as provas de seleção são opcionais. Enquanto eles ainda optam por fazer a prova em Inglês, Espanhol ou Francês.

$\mathrm{Na}$ realidade essa opção não seria o ideal, seria tão somente o cumprimento da lei 11.161/2005, que, em sua textualidade, faculta a matrícula para o aluno. Contudo, como bem afirmou Bohn (2000, p. 132), “a legislação vigente não é suficientemente robusta para garantir o direito dos cidadãos". Portanto, ainda que se tenha uma legislação específica para o ensino de Espanhol no Brasil, a mesma não é suficiente para garantir a real efetivação deste ensino.

\subsubsection{Que medidas práticas poderiam ser tomadas para a melhoria do ensino de Espanhol em escolas públicas do Distrito Federal ${ }^{104}$ ?}

Diferentemente das três últimas perguntas (que apresentaram respostas e visões com maior grau de diferença entre os profissionais de Taguatinga e do Paranoá), as medidas práticas para melhorar a realidade do ensino de Espanhol citadas nas duas RAs foram praticamente as mesmas. Dessa forma, à semelhança da pergunta $\mathrm{n}^{\circ} 1^{105}$, apresentarei as respostas das duas RAs de maneira simultânea.

A medida prática mais citada nas duas RAs para a melhoria do ensino de Espanhol foi o aumento de recursos e de material didático, como pode ser visto em:

\footnotetext{
${ }^{104}$ Esta pergunta está diretamente atrelada à pergunta $n^{\circ} 4$ (realidade ideal), visto que agora esses profissionais falam sobre as medidas "práticas", ações que eles consideram possíveis de serem tomadas para que se alcance a realidade ideal por eles apresentada.

${ }^{105}$ Em sua visão, por qual/quais motivo(s) o Espanhol foi acrescentado ao currículo das escolas públicas?
} 
P1ET1: Precisamos de mais recursos materiais como livros, apostilas, aparelhos de som e vídeo, materiais visuais e de áudio (...), laboratórios para (...) a parte cultural...

A1ET1: Uma vez que o sistema implanta um idioma (...) teria que haver todo um suporte (...). Dentro da escola pública não existe material suficiente (...) pra que o professor tivesse (...) subsídios para trabalhar (...). O aluno não tem material suficiente.

P2ET2: (...) ajudar o professor e o aluno com materiais didáticos, atualizados sempre.

P1ET5: A questão da sala equipada com equipamentos eletrônicos (...), dicionários...

A1ET8: (...) material próprio para o professor, às vezes é escasso mesmo (...), eu acho que o material para o professor, disponível, a gente tem muito pouco na escola.

P1EP1: Que nós tivéssemos recursos financeiros. Hoje mesmo eu tenho que passar um exercício de revisão "pros" alunos, eu tive que trazer folhas. Então o básico a gente não tem...

P2EP1: (...) eu acho que seria mais investimentos da direção... Eu acho que não tem um investimento necessário. Tanto em estrutura, tudo...

A1EP2: (...) a disponibilidade de recursos de áudio e vídeo, aqui na escola a gente consegue porque não é só pra Espanhol, é pra escola como um todo (...). Então a gente vai tentando dentro dos recursos que a gente tem (...) ampliar o recurso pedagógico.

A falta de recursos (tecnológicos e didáticos) ainda é uma latente realidade nas duas RAs. Contudo, tal realidade não se restringe ao DF, mas atinge o território nacional de norte a sul: escolas públicas com falta de recursos, carência de material didático e de acesso a recursos tecnológicos. Além de todas essas carências, "salvo em alguns Estados brasileiros, as escolas estão sucateadas, em mal estado de uso, sem manutenção física e desprovidas de expectativa de resolução do seu ambiente escolar" (OLIVEIRA, Aline, 2010, p. 55). Não somente isso, de acordo com as falas acima, deveria haver mais recursos direcionados à escola pelo Estado, e também ações efetivas de investimento que partam da própria direção da instituição escolar, uma vez que o professor, sozinho, não consegue realizar grandes mudanças, pois, como disse Bohn (2000), para que mudanças educacionais ocorram é necessário que haja uma vontade coletiva. Esta vontade coletiva dentro da escola exige uma parceria entre os professores e a direção, como afirma Rinaldi (2014, p. 14)

Quando mencionamos o apoio que os professores necessitam de seus diretores, referimo-nos, desde a disponibilização de uma sala de aula adequada, ou seja, ampla 
o suficiente para abrigar a quantidade de alunos que frequentam o curso, passando pela autorização para usar a máquina fotocopiadora [...].

Logo, o apoio da direção da escola é fundamental, pois em termos estruturais como os citados por Rinaldi (IBIDEM) e os citados pelos docentes, recursos podem encontrar lugar na escola não somente se o Estado ofertar, mas também se a direção redistribui-los de maneira adequada. No entanto, muitas vezes é o próprio Estado que não redistribui os recursos para a Educação. Assim, "quando o estado falta e não cumpre sua parte, outros fazem seu papel" (GONZÁLEZ, 2009), ou seja: por vezes, os próprios docentes acabam desembolsando quantias em dinheiro e materiais diversos para que as necessidades da escola sejam supridas.

Uma segunda ação muito citada foi o aumento da carga horária de Espanhol e a diminuição da carga que recai sobre o professor desta língua:

A1ET1: (...) A carga horária influencia muito... O professor (...) "tá" com o idioma, ele tem que ser professor só de Espanhol. Ele não teria como dar aula de Português e mais PD. Pois é, é o que "tá" acontecendo! Então vai terminar que ele nem dá aula de Português, nem de PD, e muito menos de Espanhol! E aí, (...) de que adiantou, essa implementação da língua dentro da grade horária?

P1ET3: Ter um número maior de professores para atender a demanda do ensino (...).

P2ET4: Acho que, a princípio, aumentar a carga horária. Sendo como o Inglês (...).

A2ET4: (...) seria diminuir um pouco a carga do professor, que é muito, é muita turma (...), dar aula pra todo mundo, dar aula pra escola inteira, né, é difícil... É difícil.

P3ET5: Aumentar a carga. Eu acho que tem como fazer. A (...) quantidade de aluno por sala, ehh, eu acho que é também, é possível ser feita. É só ter boa vontade. Sabe? Não tem necessidade de ter 50 alunos, não, que aproveitamento é esse, 50 alunos em sala de aula, 40? Então... Pra mim... É muito simples isso.

A1EP1: O principal, o inicial, é se abrir o espaço pra que a língua possa ser ministrada, né, de forma mais efetiva tanto no Ensino Médio quanto no Fundamental.

P1EP2: Eu acho que ampliação da carga horária de Espanhol nas escolas, né...

Mais uma vez, a problemática da carga horária surge como uma situação emergencial no ensino de Espanhol. Este fator desencadeia muitos outros como o professor de Espanhol ministrar também aulas de outras disciplinas, o pouco número de professores de Espanhol em uma escola (geralmente, no máximo dois), as inúmeras turmas que este professor tem, e 
consequentemente; inúmeros alunos, inúmeros diários de classe, inúmeras provas e avaliações para corrigir, inúmeras notas para lançar. Dessa maneira, a carga horária afeta não somente o aluno, privado de um ensino de melhor qualidade, mas imensamente ao professor de Espanhol, que, desgastado pelas situações apresentadas, ainda esbarra em problemas de caráter estrutural.

Ainda sobre a carga horária, dois professores de Taguatinga apresentaram como uma medida prática possível a seguinte sugestão:

P1ET6: Bom, aqui na escola eu trabalho com PD. Então se (...) essa carga de PD, se ela fosse revertida pra Espanhol, poderia ter um resultado maior, porque em algumas escolas o $P D$ é uma, uma matéria complementar. Então se eu tenho uma necessidade de ensinar melhor o Espanhol pro meu aluno eu acredito que seria complementar pra ele aprender bem aquilo (...). Uma medida prática e... Talvez de fácil aplicação.

P1ET7: Logo de cara a gente tirar essas aulas de PD e converter em aulas de Espanhol, e a gente ter duas aulas semanais (...), porque realmente existe PD ainda que não serve pra nada (...) o aluno nem reprova em PD (...). Aí teria mais um professor, eu não daria aula pra tanta turma, daria pra metade das turmas apenas (...).

A conversão de PD em aulas de Espanhol já tem sido realizada em uma escola de Taguatinga (ET8) e em uma escola do Paranoá (EP2). Nos fragmentos acima os professores exemplificam a realidade do ensino de PD nas escolas: uma matéria complementar que às vezes "não serve pra nada". Ainda que tal afirmação seja contundente, infelizmente a realidade fala por si mesma. Além de ter mais uma aula semanal que seria, segundo os professores, bem utilizada, complementar e necessária, o número de turmas do professor de Espanhol diminuiria pela metade, o que já seria um avanço significativo e uma grande melhoria.

A terceira medida prática bastante citada por esses profissionais, mais uma vez, diz respeito à formação dos professores:

P2ET4: (...) Propiciar aos professores algum curso de apoio ou reforço, pois como a demanda é grande, muito professores só têm o curso de graduação (Letras/Espanhol)...

P1ET5: (...) oportunizar o professor (...). Não adianta a gente ir pra um curso da EAPE se... Se não vai acrescentar... O ano passado eu fui, foi excelente (...), mas ali a diversidade era 
grande. Era professor (...) dos CILS, que falam muito bem, e professores que estavam iniciando (...), eram duas realidades distintas (...). Então eu acho que uma das coisas de imediato era qualificação do professor (...).

A1ET8: (...) capacitar o profissional da língua (...), cursos de formação continuada...

P1EP2: (...) capacitação de professores (...). Eu acho que isso ainda falta. A Secretaria de Educação fez nos últimos anos duas capacitações, uma a cada semestre (...). Funciona bastante, mas a maioria do público que eu vejo nessa capacitação ainda é de Centros de línguas... Que é uma galera super capacitada! Então quem já está no Centro de línguas é... Tem uma formação maior... No professor. E o que eu vejo na sala de aula é muito professor que, pela carga horária, se perde ou não sabe o que fazer.

Pelas falas acima, é perceptível que os próprios professores não se sentem de fato suficientemente capacitados para ministrar aulas de Espanhol, pois muitos possuem somente o curso de graduação (em sua maioria, licenciaturas duplas), sem uma formação continuada. Cabe destacar que as duas professoras que citaram cursos de capacitação citaram os professores dos Centros de Línguas como aqueles que "falam muito bem”, "galera super capacitada", com uma "formação maior", resultando, em suas visões, em "duas realidades distintas". Logo, nessas falas é possível perceber a comparação implícita (e talvez inconsciente) dessas professoras de ensino regular com os professores dos Centros de Línguas, as quais se sentem menos capazes de ministrar aulas de Espanhol com segurança, e também, menos capacitadas.

Infelizmente, dada a realidade do ensino regular, muitos professores não têm acesso à formação continuada em função de motivos diversos, como os apresentados por Rinaldi (2014, p. 13) ao dizer que

[...] muitos professores deixam de encontrar motivação para continuar seus estudos, pois quando o próprio governo oferece cursos de atualização, não há permissão para que os professores se ausentem da sala de aula, seja por falta de professor substituto, seja por outro inconveniente qualquer. Se o curso de aperfeiçoamento é oferecido por outra instituição e, eventualmente, é pago, poucos são os professores que têm condições de arcar com os valores de cursos de formação continuada.

Sendo assim, nem sempre a formação continuada está ao alcance do professor do ensino regular em função dos problemas estruturais que sua ausência geraria (como a 
necessidade de um professor substituto, por exemplo). Contudo, DIAS (2014, p. 9) elucida que

\begin{abstract}
[...] a aprendizagem da Língua Espanhola constitui-se um direito fundamental do estudante e que, para que isso ocorra ao longo da Educação Básica, é imprescindível que sejam garantidas as condições de sua operacionalização em termos de políticas públicas assumidas como obrigação de Estado, com implicações administrativas, políticas e pedagógicas, nos diferentes contextos de ensino e das escolas do país: a formação de professores e a valorização da língua estrangeira [...].
\end{abstract}

Portanto, além de ser um direito do aluno, a aprendizagem de Espanhol requer a garantia de políticas públicas efetivas com reais implicações de caráter administrativo, político e pedagógico, dentre as quais a formação de professores configura-se primordial. Logo, é dever do Estado, em parceria com as Secretarias de Educação e os órgãos competentes (como as Embaixadas, por exemplo), promover cursos gratuitos de atualização para o professor atuante em sala de aula, sem que estes necessitem desembolsar valores exorbitantes para uma melhor qualificação.

Dois profissionais citaram como medida prática para um ensino efetivo de Espanhol sua inclusão no Ensino Fundamental:

\title{
A2EP2: Estender o Espanhol nas séries iniciais.
}

P2EP2: (...) porque o Espanhol não pode ser oferecido (...) no Ensino Fundamental? (...). Eu fui fazer estágio do Português (...) e eu fui numa turma de $5^{a}$ série, de $6^{o}$ ano, e eles ficaram loucos quando a professora falou "ahh, essa aqui é a professora P2EP2, ela dá aula de Espanhol”, e eles falaram assim: "ah, dá aula de Espanhol pra gente, professora” (...), “professora, por que a gente não tem Espanhol aqui na escola?”(...). Eu falei: "ah gente, ai já é uma decisão politica...". Inclusive eu "tava” até dando uma lida na lei, né, e é realmente, é facultativa, né, essa oferta no Ensino Fundamental (...). Então eu acho que seria (...) interessante se pudesse ser oferecido antes, porque aí os meninos teriam um contato maior com a língua (...).

É válido ressaltar na fala de P2EP2 a reação dos alunos de Ensino Fundamental ao saber que ela dava aulas de língua espanhola. Esta docente, ciente de que a inclusão (e exclusão) do Espanhol consistia em uma decisão política, posteriormente "deu uma lida na lei", chegando ao questionamento inicial de sua fala: "porque o Espanhol não pode ser 
oferecido (...) no Ensino Fundamental?”. Sobre essa questão, Viñal Júnior (2012b, p. 2) afirma que é necessário que os professores de LE, seguindo o exemplo de P2EP2, "tomen posesión de la conciencia crítica al analizar las leyes y los parámetros relacionados con la enseñanza de idiomas, ya que esto puede servir como un objeto de la inclusión o exclusión, una manera de ejercer el poder y la opresión”. Desse modo, é necessário que os professores tenham uma visão crítica das leis que regem a educação brasileira, tendo em vista que o posicionamento vem pelo conhecimento. Como posicionar-se criticamente se não se conhece? Como efetivar reais mudanças e melhorias no ensino sem o conhecimento das legislações educacionais?

Por fim, convém destacar o pensamento de duas professoras:

P2ET5: (...) seria a questão politica. (...). Se você me perguntasse assim: “(...) qual o seu ideal, qual o (...) seu sonho pra educação?", atualmente eu não "tô" tendo sonho. O que eu "tô" tendo é pesadelo, cada dia mais (...). Eu vejo que a medida prática seria, com o perdão da palavra, eh, mais a vergonha, falta vergonha na cara dos políticos, né, de quem governa o país. (...) O que precisa ser mudado na prática é isso! Né, ah, a estrutura realmente, o Brasil (...) priorizar a educação, na prática o que precisa é isso.

P1EP1: (...) se a gente tivesse (...) pessoas que (...) estão na administração e tivessem passado por uma sala de aula (...). Esses administradores são simplesmente administradores. Eles não foram professores em nenhum momento. Eles não conhecem a nossa realidade! Então... Boa vontade falta...

Para essas professoras, a mudança deveria partir de cima para baixo, ou seja, do governo para a população, por meio de uma verdadeira tomada de consciência. Porém, infelizmente políticos em geral não são pedagogos e nem professores (CELANI, 2008), desconhecendo a realidade da prática escolar e prosseguindo a priorizar nas políticas educacionais a prevalência de motivações de ordem econômica e social.

Com base nos fragmentos apresentados, é possível resumir e elencar as respostas dos professores e assistentes das duas RAs no seguinte quadro: 
Quadro 7 - Síntese das respostas da entrevista com docentes e assistentes

\begin{tabular}{|c|c|c|}
\hline PERGUNTA & TAGUATINGA & PARANOÁ \\
\hline $\begin{array}{l}\text { 1. Em sua visão, por } \\
\text { qual/quais motivo(s) o } \\
\text { Espanhol foi acrescentado } \\
\text { ao currículo das escolas } \\
\text { públicas? }\end{array}$ & $\begin{array}{l}\text { 1. Mercosul } \\
\text { 2. Fronteira } \\
\text { 3. Proximidade linguística } \\
\text { 4. Interesses comerciais } \\
\text { 5. Outra língua além do Inglês } \\
\text { 6. Importância do Espanhol } \\
\text { no mundo }\end{array}$ & $\begin{array}{l}\text { 1. Mercosul } \\
\text { 2. Fronteira } \\
\text { 3. Interesses comerciais } \\
\text { 4. Outra língua além do } \\
\text { Inglês } \\
\text { 5. Importância do Espanhol } \\
\text { no mundo }\end{array}$ \\
\hline $\begin{array}{lrr}\text { 2. Como } & \text { professor, quais } \\
\text { as suas } & \text { satisfações } & \text { em } \\
\text { relação ao } & \text { aonsino } & \text { de } \\
\text { Espanhol } & \text { em } & \text { escolas } \\
\text { públicas } & \text { do } & \text { Distrito } \\
\text { Federal? } & & \end{array}$ & $\begin{array}{l}\text { 1. Motivação do aluno } \\
\text { 2. Optar pelo Espanhol no } \\
\text { vestibular e Enem } \\
\text { 3. Oferecimento da língua } \\
\text { 4. Estudo da língua } \\
\text { extracurricular } \\
\text { 5. Relação interpessoal }\end{array}$ & $\begin{array}{l}\text { 1. Ministrar a aula em } \\
\text { Espanhol } \\
\text { 2. Trabalhar a oralidade } \\
\text { 3. Motivação do aluno } \\
\text { 4. Optar pelo Espanhol no } \\
\text { vestibular e Enem } \\
\text { 5. Oferecimento da língua }\end{array}$ \\
\hline \begin{tabular}{llr}
$3, \quad$ Quais & as & suas \\
insatisfações & (dificuldades) \\
em relação ao & ensino de \\
Espanhol em & escolas \\
públicas & do & Distrito \\
Federal? De & que & maneira \\
essas & \multicolumn{2}{c}{ dificuldades } \\
prejudicam & o & ensino- \\
aprendizagem?
\end{tabular} & $\begin{array}{l}\text { 1. Pouca carga horária (não } \\
\text { trabalhar oralidade e } \\
\text { gramática) } \\
\text { 2. Falta de pré-requisito na } \\
\text { língua materna } \\
\text { 3. Escassez de material } \\
\text { didático }\end{array}$ & $\begin{array}{l}\text { 1. Escassez de material } \\
\text { didático } \\
\text { 2. Falta de estrutura } \\
\text { 3. Número de alunos em } \\
\text { sala } \\
\text { 4. Não oferecer Espanhol } \\
\text { no Ensino Fundamental } \\
\text { 5. Formação inicial e } \\
\text { continuada }\end{array}$ \\
\hline $\begin{array}{l}\text { 4. Em sua opinião, como } \\
\text { seria a realidade ideal de } \\
\text { ensino de Espanhol em } \\
\text { escolas públicas do Distrito } \\
\text { Federal? }\end{array}$ & $\begin{array}{l}\text { 1. Aumento da carga horária } \\
\text { 2. Aluno optar pelo estudo da } \\
\text { língua } \\
\text { 3. Menor número de alunos } \\
\text { 4. Formação continuada }\end{array}$ & $\begin{array}{l}\text { 1. Menor número de alunos } \\
\text { 2. Utilização das TICS } \\
\text { 3. Oferecer Espanhol no } \\
\text { Ensino Fundamental } \\
\text { 4. Aluno optar pelo estudo } \\
\text { da língua }\end{array}$ \\
\hline $\begin{array}{l}\text { 5. Que medidas práticas } \\
\text { poderiam ser tomadas } \\
\text { para a melhoria do ensino } \\
\text { de Espanhol em escolas } \\
\text { públicas do Distrito } \\
\text { Federal? }\end{array}$ & $\begin{array}{l}\text { 1. Aumento de recursos e de } \\
\text { material didático } \\
\text { 2. Aumento da carga horária } \\
\text { 3. Converter aulas de PD em } \\
\text { aulas de Espanhol } \\
\text { 4. Formação continuada }\end{array}$ & $\begin{array}{l}\text { 1. Aumento de recursos e } \\
\text { de material didático } \\
\text { 2. Aumento da carga } \\
\text { horária } \\
\text { 3. Formação continuada } \\
\text { 4. Oferecer Espanhol no } \\
\text { Ensino Fundamental }\end{array}$ \\
\hline
\end{tabular}

Fonte: Autoria própria

Após a apresentação e discussão dos dados gerais desta pesquisa, a seguir apresentarei os dados específicos, bem como sua discussão e análise. 


\subsection{DADOS ESPECÍFICOS: DELIMITAÇÃO}

Após a exposição e análise dos dados gerais desta pesquisa, serão apresentados e analisados os dados específicos. Meu objetivo com os dados gerais foi através da análise das escolas de Ensino Médio de Taguatinga e Paranoá em sentido estrutural, demonstrar o panorama de ensino de Espanhol no nível de DF. Já os dados específicos são referentes a uma escola de Ensino Médio de cada RA analisada nesta dissertação, nas quais serão demonstradas a vivência escolar das aulas de Espanhol. Nessas duas escolas observei uma turma de $3^{\circ}$ ano do Ensino Médio durante um tempo determinado, a fim de acompanhar o dia a dia das aulas de Espanhol e verificar se as realidades de ensino são compatíveis ou distintas. Os dados específicos apresentados a seguir foram coletados entre os meses de abril e agosto de 2014.

É válido relembrar que o estudo de casos múltiplos (YIN, 2010) ou coletivo (STAKE, 1995) abarca mais de um caso, podendo compreender mais de uma escola, professor ou realidade, como nesta dissertação: a análise da realidade de ensino de Espanhol de duas RAs do DF, e de uma turma de Ensino Médio de cada RA pesquisada. Além de buscar compreender eventos contemporâneos e fenômenos sociais complexos (YIN, op. cit., p. 32), o estudo de caso é considerado um "retrato vivo da realidade" (ANDRÉ, 1984, p. 53), investigando problemas práticos e utilizando diversos instrumentos de coleta de dados (GIL, 2010). Nesta etapa da pesquisa foram utilizados os seguintes instrumentos: a) notas de campo, b) observação participante, c) entrevista livre e d) questionário.

Por fim, em concordância com Chizzotti (2006, p. 135, grifo meu), cabe destacar que o estudo de caso "[...] visa auxiliar tomadas de decisão, ou justificar intervenções, ou esclarecer por que elas foram tomadas ou implementadas e quais foram os resultados", como pretende essa pesquisa em relação à Lei 11.161/2005.

\subsubsection{Calendário de Observações}

Ao refletir sobre quanto tempo eu observaria as duas turmas, eu e minha orientadora decidimos pela observação de no máximo, um bimestre letivo. Em função da estruturação das turmas que ocorre no $1^{\circ}$ bimestre, iniciei minhas observações no $2^{\circ}$ bimestre de 2014. Infelizmente, por intervenções e eventos ocorridos na escola de Taguatinga nos dias das 
observações (feriado, jogos interclasse, falta da professora, provas) ${ }^{106}$, observei em Taguatinga um número consideravelmente menor de aulas, necessitando realizar as duas últimas observações após o recesso escolar. Essa diferença também ficou evidente em função da diferença de carga horária: 4 aulas por semana no Paranoá e somente 1 aula semanal em Taguatinga. Abaixo, as datas das observações:

Tabela 7 - Datas das observações (Taguatinga e Paranoá)

\begin{tabular}{|c|c|}
\hline $\begin{array}{l}\text { TAGUATINGA (1 aula por semana). } \\
\text { Carga semanal: } 1\end{array}$ & $\begin{array}{l}\text { PARANOÁ (duas aulas duplas, duas } \\
\text { vezes na semana). Carga semanal: } 4\end{array}$ \\
\hline 1. $16 / 04 / 2014: 1^{a}$ observação & 1. $15 / 04 / 2014: 1^{a}$ observação \\
\hline 2. $09 / 05 / 2014: 2^{\mathrm{a}}$ observação & 2. 29/04/2014: $2^{a}$ observação \\
\hline 3. $23 / 05 / 2014: 3^{a}$ observação & 3. $06 / 05 / 2014: 3^{a}$ observação \\
\hline 4. $30 / 05 / 2014: 4^{\mathrm{a}}$ observação & 4. $08 / 05 / 2014: 4^{\mathrm{a}}$ observação \\
\hline 5. $01 / 08 / 2014: 5^{a}$ observação & 5. 13/05/2014: $5^{\mathrm{a}}$ observação \\
\hline \multirow[t]{4}{*}{ 6. $08 / 08 / 2014: 6^{a}$ observação } & 6. 20/05/2014: $6^{a}$ observação \\
\hline & 7. $22 / 05 / 2014: 7^{\mathrm{a}}$ observação \\
\hline & 8. $27 / 05 / 2014: 8^{a}$ observação \\
\hline & 9. 29/05/2014: $9^{a}$ observação \\
\hline Total de aulas observadas: 6 aulas & Total de aulas observadas: 18 aulas \\
\hline
\end{tabular}

Fonte: autoria própria

\subsubsection{As duas escolas e as turmas observadas}

As escolas escolhidas já foram apresentadas nesta dissertação: em Taguatinga trata-se da escola ET2, e no Paranoá trata-se da escola EP1 ${ }^{107}$. Minha escolha por essas duas escolas especificamente se deu pela realidade que as duas apresentam, visto que são duas escolas grandes, conceituadas e importantes para a comunidade escolar de suas RAs. Sobre essas

\footnotetext{
${ }^{106}$ De fato, como muitos docentes de Taguatinga relataram nos enxertos dos dados gerais, qualquer intervenção que impossibilite as aulas resulta em menos encontros com os alunos, dificultando o processo de ensinoaprendizagem. Na coleta de dados esta realidade tornou-se uma das limitações de minha pesquisa, pois de 16 de abril até 30 de maio os alunos de Taguatinga tiveram somente 4 aulas de Espanhol, ao passo em que no mesmo período, os alunos da turma do Paranoá tiveram 9 aulas duplas. As intervenções em Taguatinga foram: 23/04: falta da professora (doença), 02/05: feriado, 16/05: jogos interclasse. Assim, necessitei retornar à turma de Taguatinga após o recesso escolar.

${ }^{107}$ Para reler a realidade em termos estruturais das duas escolas: ET2 (p. 112) e EP1 (p. 126).
} 
escolhas do foco (lócus) de investigação, concordo com Ludke e André (2013, p. 27) quando afirmaram que

[...] a questão de escolher, por exemplo, uma escola comum da rede pública ou uma escola que esteja desenvolvendo um trabalho especial dependerá do tema de interesse, o que vai determinar se é num tipo de escola ou em outro que a sua manifestação se dará de forma mais completa, mais rica e mais natural.

Optei por analisar duas turmas de $3^{\circ}$ ano do Ensino Médio, pois são alunos que já vivenciaram o ensino de Espanhol por dois anos, logo, estão "concluindo" seus estudos da língua no ensino regular. Assim, pretendi identificar impressões sobre suas experiências com o estudo da língua na escola. Cabe destacar que para a escolha das turmas analisadas em cada RA não utilizei nenhum critério especifico: escolhi as duas turmas que melhor se encaixavam em minha disponibilidade de horário para as observações. Antes da escolha não tive nenhum conhecimento sobre o perfil das duas turmas. Com base nessas considerações, de maneira breve relatarei a seguir as diferenças entre as duas escolas no que se refere à implantação do Espanhol e à descrição da professora e turma observada.

\subsubsection{ET2: Implantação, professora e turma}

A escola de Taguatinga (ET2) implantou o Espanhol no ano de 2010, e desde então, nenhuma mudança referente à situação da disciplina foi tomada, uma vez que até hoje o Espanhol permanece com a mesma carga horária e as mesmas condições.

A professora de Espanhol que ministrou as aulas observadas em Taguatinga é P1ET2. A partir desse momento, irei chamá-la de Helena ${ }^{108}$. Helena tem 44 anos e é uma professora efetiva há 25 anos. Sua formação inicial é licenciatura dupla em Espanhol e Português e não possui pós-graduação. Durante 20 anos ministrou aulas de Português, e a partir de 2010 começou a lecionar Espanhol. Na ET2 Helena dá aulas de Espanhol a 28 turmas (todas as turmas do turno matutino).

Helena contou-me que decidiu mudar do ensino de LM para o ensino de LE como um desafio pessoal. Porém, embora esteja dando aula de Espanhol há 4 anos, ainda tem

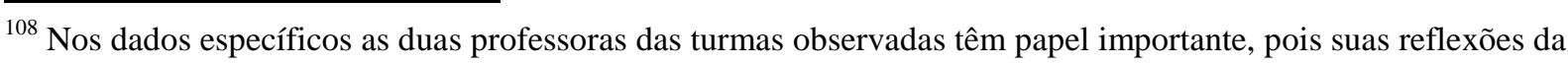
prática docente elencam esta análise de dados. Por isso, como uma maneira de valorizá-las decidi nomeá-las com pseudônimos escolhidos por elas. Vale ressaltar que nesta pesquisa não há a pretensão de avaliar a atuação docente das professoras, visto que o objetivo das observações é tão somente conhecer suas realidades de ensino de Espanhol.
} 
temores em sua prática e de certa forma, insegurança. Disse-me que faz cursos de atualização e que estava preocupada, pois os cursos já estavam terminando e assim, teria de caminhar "sozinha". Entretanto, ao longo das observações concluí que se trata de uma professora esforçada e competente, preocupada e envolvida emocionalmente com seu trabalho e sua prática docente, pois em diversos encontros nossos, emocionou-se ao relatar sua realidade de ensino de Espanhol. Helena fez render cada aula de 45 minutos que observei, mostrando domínio e bom conhecimento de Espanhol, explicando de maneira pontual e muito detalhada. Dava atenção aos aspectos sintáticos das estruturas gramaticais, o que julguei um diferencial muito positivo em suas explicações, ainda que sua aula fosse de abordagem gramatical. Concluo que este diferencial se deve à sua atuação docente anterior (20 anos ministrando aulas de língua portuguesa).

A turma analisada em Taguatinga é considerada na escola uma turma "rebelde". Nos momentos em que a turma estava mais "cheia" havia entre 26 a 28 alunos presentes. Apesar da falta de interesse claramente evidenciada em algumas observações, os alunos desta turma não apresentaram mal comportamento em todas as aulas, sendo inclusive, muito solícitos em ajudar-me quando necessitei que preenchessem o questionário ${ }^{109}$.

\subsubsection{EP1: Implantação, professora e turma}

No Paranoá, optei pela análise da EP1. Pioneira no ensino de Espanhol em escolas públicas regulares no DF, atualmente é considerada referência no ensino de Espanhol devido à sua realidade, fruto de luta e dedicação. É válido comentar o percurso do Espanhol na EP1, que implantou o Espanhol no ano de $2006^{110}$ com apenas uma aula semanal, vivenciando muitas limitações, como lembram as duas professoras desta escola que iniciaram o trabalho, ao falar sobre aquela época:

P1EP1: Insatisfação total. Era fazer a chamada, conversar rapidamente com os alunos... Não havia tempo pra passar filmes, a gente começava a trabalhar uma música, a aula terminava... Total insatisfação (...). [Sobre ministrar todo o conteúdo]: Nunca! Nunca, impossível (...) com 45 minutos. 45 minutos e 45 alunos... (risos).

P2EP1: Não dava pra fazer nada, 45 minutos era (...) da pessoa ficar desmotivada. Não consegue fazer nada, você não consegue dar uma aula.

\footnotetext{
${ }^{109}$ O questionário aplicado aos alunos será o último item desta análise de dados específicos.

${ }^{110}$ A EP1 foi a primeira escola do DF a implantar o Espanhol, como programa-piloto.
} 
Além das dificuldades da carga horária, não havia material didático:

P1EP1: Nós não tínhamos nada (...). Não tínhamos papel, não tínhamos material, nem pra tirar Xerox tinha, nada, não tínhamos livro, era assim. Então era boa vontade.

P2EP1: Não tinha livro, não tinha nada! (...). No começo era difícil porque pra eles [alunos] comprarem o livro era um pouco difícil e aí, uma turma de 45 alunos, 5 tinham...

Logo, é possível perceber que o fato de terem sido a primeira escola a implantar o Espanhol no DF gerou dificuldades como a falta de material, visto que nesta época ainda não havia sido disponibilizado às escolas o livro didático da língua, reproduzindo a dura realidade que os PCNEM (BRASIL, 2000, p. 25) já haviam retratado ao afirmarem que "[...] o país vivenciou a escassez de materiais didáticos que, de fato, incentivassem o ensino e a aprendizagem de Línguas estrangeiras; quando os havia, o custo os tornava inacessíveis a grande parte dos estudantes".

Portanto, dada essa realidade, a direção, os professores e os alunos iniciaram uma mobilização conjunta para realizar uma mudança, principalmente após constatar que de cada dez alunos da escola, nove escolhiam o Espanhol como LE no vestibular. Motivados, os alunos fizeram um abaixo-assinado para que a carga horária da disciplina fosse de duas aulas semanais, tornando-se, assim, elementos determinantes para a mudança:

P1EP1: Partiu deles (...). Então eu acho que o grande diferencial realmente foi o aluno. A consciência de que... Da forma como estava não teria condições de aprender. E aí a gente aproveitou esse momento que o aluno também queria, nós também queríamos... E deixamos de fazer trabalho de formiguinha.

Assim, foi criado um projeto diferenciado ${ }^{111}$ para o ensino de Espanhol na EP1. Este projeto foi levado à Regional de Ensino do Paranoá, e não demorou muito para que as mudanças começassem a acontecer: inicialmente, conseguiram mais um professor de Espanhol. Em 2007 já foi feita a redistribuição da carga horária, e o Espanhol na EP1 passou a ter duas aulas semanais, pois recebeu um horário antes destinado ao Ensino Religioso. Atualmente a escola opera em regime de semestralidade, logo, o Espanhol tem quatro aulas semanais durante um semestre letivo.

\footnotetext{
${ }^{111}$ Infelizmente não pude ter acesso a esse projeto, ouvindo sobre ele e suas propostas nas falas das professoras da escola.
} 
O que aconteceu na EP1 foi descrito por Bohn (2010, p. 128) como "vontade coletiva". De acordo com o autor, as mudanças educacionais apenas serão possíveis "na medida em que se construa uma vontade coletiva na direção dessas mudanças. [...]. Somente o somatório de forças pode construir a vontade coletiva necessária para a ação política”, como de fato, ocorreu na EP1 em 2006: mobilização e vontade coletiva dos professores, dos alunos e inclusive, da direção, sem a qual nada poderia ter sido feito:

P1EP1: Se nós não tivéssemos também (...) a ajuda da direção nesse primeiro momento, nós não teríamos conseguido. A escola precisa trabalhar de forma única né, tendo o mesmo objetivo. Se só uma parte (...) pensa da mesma forma, não se consegue.

P2EP1: [...] como existe boa vontade da direção, graças a Deus sempre existiu, né, desde o começo, já no segundo ano a gente conseguiu ampliar a carga, né, pra uma hora e meia, então existe a boa vontade da direção, e facilita muito o trabalho da gente.

Cabe destacar que esta escola é apoiada pela Embaixada da Espanha. Assim, já participou de muitos projetos como a "Pipa Literária" e o "El país nas escolas", contribuindo para que o contato do aluno com o Espanhol seja mais efetivo.

A professora da turma observada na EP1 é P2EP1, que será nomeada "Magali". Professora Magali tem 46 anos e é professora efetiva 40h há oito anos. Possui dupla habilitação em Português e Espanhol e, há 8 anos, logo após terminar sua graduação, iniciou sua carreira docente na EP1, permanecendo na escola até hoje. Atualmente ministra aulas de Espanhol em 6 turmas. Esta professora possui duas especializações: uma em Língua Espanhola e outra em Tradução, e já viajou para a Espanha e para o Chile.

Através das observações percebi que Magali é uma professora amável, tranquila, paciente e tem bom relacionamento com seus alunos (ainda que muitos tenham reclamado de sua didática "estrutural"). Não costuma demorar muito em suas explicações e valoriza muito o livro didático, ministrando todas as aulas em Espanhol. Ainda que possua uma carga horária razoável para as aulas, grande parte do tempo é destinada a exercícios gramaticais escritos.

A turma observada na EP1 é grande e agitada, porém disciplinada. Nas observações, quando cheia, a turma contava com em média, 35 alunos.

Com base nas considerações feitas, a seguir apresento a análise das observações realizadas e o contraste entre as realidades encontradas nas duas RAs. 


\subsection{As observações e as realidades apresentadas}

\section{OBSERVAÇÃO 1}

TAGUATINGA: Esta aula é depois do intervalo. Logo, a aula começou atrasada, pois os alunos demoraram a chegar. Mal entraram na sala e começaram a perguntar sobre as notas. Ao dizer que ainda não tinha fechado as notas, professora Helena foi questionada de forma irônica por um aluno: "Ué, professora, o que a senhora faz das 23 h às 08h?". Chateada, Helena respondeu: "Gente, eu tenho as 28 turmas. É engraçado como a cobrança só vem encima de nós”.

Esta aula antecipou um feriado, por isso, havia somente 12 alunos em sala. A atividade planejada para a aula seria trabalhada no livro, entretanto, os alunos não levaram o livro didático. Aborrecida pela falta do livro, Helena aplicou um exercício de vocabulário $^{112}$ para fazer em dupla, e passou aos alunos as páginas que trabalhariam na aula seguinte: 10, 11 e 12. Helena distribuiu a atividade aos alunos e disse: "gente, façam, se não, não vai dar tempo e eu vou dar o visto hoje". Durante todo o tempo em que os alunos fizeram o exercício somente duas alunas chamaram a professora para tirar dúvidas. Nesse tempo, Helena conversou comigo e me apresentou o livro (Enlaces 3) que começariam a trabalhar na aula seguinte nas páginas indicadas. Cinco minutos antes de a aula acabar os alunos começaram a levar o caderno até a professora para que esta conferisse a atividade. A aula acabou. Enquanto eu guardava meus materiais, outra turma rapidamente entrou na sala e Helena cobrou o livro. Uma aluna reclama: "Ah não, professora, não vai dar tempo!".

Logo no início dessa aula foi possível perceber a cobrança dos alunos sobre a professora, confirmada por sua primeira fala relatada na observação. Observa-se a sobrecarga de Helena, como ela me relatou ao afirmar: "Eu não posso fazer nada individual com eles. Não tem como eu corrigir mais de mil trabalhos (...), mais de mil provas, não tem como eu fazer um diálogo mesmo que seja em dupla, em 45 minutos...”. Assim, além do cansaço físico que um professor com 28 turmas tem, há o extremo cansaço mental que, já presente na profissão, nessas condições aumenta significativamente.

Neste dia os alunos não levaram o livro para a aula, e por causa do feriado, muitos faltaram. Dessa maneira, é notável a falta de interesse desses alunos em relação à disciplina, também evidenciado enquanto realizaram o exercício. Os alunos parecem não ver no Espanhol uma disciplina "necessária e também relevante para a sua formação" (DIAS, 2014, p. 5). A carga horária também contribui para esse desinteresse, como demonstra a última frase proferida por uma aluna quando diz que "não daria tempo" para realizar exercícios no livro. A preocupação da professora com o tempo é latente, bem como a otimização do mesmo: em 45 minutos Helena aplicou um exercício, explicou e conferiu os livros dos alunos.

\footnotetext{
${ }^{112}$ Anexo H.
} 
Por fim, o que mais me chamou a atenção foi a professora começar a usar o livro didático somente no $2^{\circ}$ bimestre (a página 10 é o início do livro!). Por falta de pré-requisito dos seus alunos em Espanhol, durante o $1^{\circ}$ bimestre Helena fez uma revisão de conteúdos básicos como muy x mucho, buen x bueno, pronomes pessoais, etc.

\section{OBSERVAÇÃO 1}

PARANOÁ: Antes de começar a aula a professora Magali recebeu cópias de uma prova do vestibular da UnB de 2006 e me disse que trabalharia a resolução da prova em uma de suas aulas. Hoje esta turma está iniciando o $2^{\circ}$ bimestre. Os alunos conversam e riem alto, e a professora arruma seus materiais, em silêncio. Em seguida, anota no quadro as atividades avaliativas do $1^{\circ}$ bimestre: três provas escritas, uma atividade sobre um conto literário em Espanhol lido em sala e uma atividade sobre um filme que os alunos assistiram em sala. Em Espanhol, Magali comenta as avaliações e em seguida entrega aos alunos a atividade referente ao filme.

Magali chama aluno por aluno até sua mesa, e comenta as notas das avaliações de cada um. Após este momento, pede que os alunos abram seus livros (Síntesis 3) na página 45, para iniciarem a trabalhar o "Subjuntivo". Os 30 alunos presentes, antes agitados e gritando, silenciam quase que totalmente. A professora somente lê a explicação do tempo verbal e a maioria dos alunos acompanha. Em seguida, iniciam os exercícios da página 46 com o auxílio do quadro de verbos que aparece no livro.

Percebi que apenas duas alunas não estavam fazendo o exercício. Ao parar de explicar, Magali passa entre as carteiras para tirar as dúvidas. Todas as explicações são em Espanhol. Com o passar do tempo os alunos voltam a conversar, enquanto alguns levam o livro para a professora conferir. Faltando meia hora para a aula acabar os alunos ainda fazem o mesmo exercício, o que os deixou agitados, uma vez que muitos já haviam terminado.

Em contrapartida, a aula de 1h30min observada no Paranoá pareceu render mais. Inicialmente julguei muito positivo a professora poder trabalhar uma prova de vestibular em sala. Me perguntei se isso seria possível na realidade de Taguatinga, na qual as poucas aulas são destinadas ao trabalho dos conteúdos propostos para a série. Também me pareceu positivo o conjunto das atividades avaliativas: além das provas escritas, os alunos tiveram a oportunidade de ler um conto em Espanhol e assistir a um filme em sala. Ainda que a sala da turma observada em Taguatinga possua televisão, certamente em uma aula não daria para assistir um filme inteiro. Esta turma também se apresentou mais disciplinada, pois grande parte fez silêncio e iniciou a realizar o exercício.

Enquanto os alunos da ET2 iniciariam o trabalho com o livro, os alunos da EP1 começavam a ver a p. 45, demonstrando o avanço do conteúdo. Cabe destacar o atendimento individual que Magali deu a cada aluno ao comentar suas notas, o tempo que teve para passar entre as carteiras e a tranquilidade da professora em suas ações, diferente de Helena, que 
pareceu apressada e aflita com o tempo. Outro ponto muito positivo foi a aula ter sido ministrada toda em Espanhol, o que não aconteceu em Taguatinga. Contudo, o único ponto negativo que percebi foi a distribuição do tempo, uma vez que a aula toda ( $1 \mathrm{~h} 30 \mathrm{~min})$ somente destinou-se ao trabalho com o conteúdo de uma página do livro.

\section{OBSERVAÇÃO 2}

TAGUATINGA: Os alunos demoram um pouco para chegar. Uma aluna cumprimenta Helena: "Hola, como estás?". Após Helena dizer que está bem, a aluna comenta: "eu só sei falar isso desde o ano passado...". A turma já está com 22 alunos, e a professora pede que os alunos que trouxeram o livro o abram na p. 8. A turma está tranquila, em silêncio, enquanto a professora explica o conteúdo em Português e em seguida, o exercício, fazendo perguntas aos alunos. Helena introduz o "Condicional" e o explica detalhadamente no quadro, enquanto os alunos, em silêncio, prestam atenção. Após a explicação, a professora explica o exercício e os alunos começam a fazê-lo.

Enquanto alguns poucos alunos resolvem o exercício, Helena faz a chamada e passa de carteira em carteira para conferir a atividade. Alguns alunos tiraram o livro da mochila apenas quando a professora passou por sua carteira, enquanto outros alunos levaram o livro até a professora.

Uma professora de Português passa para avisar aos alunos que, como estão sem aulas de Português devido à falta de professor, poderiam assistir a suas aulas nos horários vagos a fim de melhor se preparar para o vestibular. Ela pergunta quem vai fazer o vestibular e dos 28 alunos presentes, somente 10 levantaram a mão... Por fim, após a saída desta professora, Helena dá alguns avisos. Fala que as inscrições do ENEM já estão abertas, e explica as diversas utilizações da nota desse exame.

Inicialmente, pela segunda fala da aluna que cumprimentou Helena ao chegar à sala são perceptíveis as lacunas no ensino de Espanhol para esta aluna, pois segundo ela, desde o ano passado somente sabe dizer: "Hola, como estás?". Nesse sentido, é válido o questionamento: A que se deve tão grande lacuna em uma aluna do $3^{\circ}$ ano do Ensino Médio? Não pretendo fazer generalizações, porém me questiono se será este o conhecimento da maioria dos alunos do $3^{\circ}$ ano da ET2.

Nesta aula a turma está mais tranquila. Em silêncio, prestam atenção e alguns fazem a atividade proposta. A professora, sempre agitada (buscando não perder tempo), desdobra-se em sala, e mais uma vez faz render o tempo: conversou com os alunos, explicou o conteúdo, os alunos realizaram a atividade, a professora olhou os cadernos e ainda conversaram sobre o vestibular e o ENEM. Helena me explicou: "a gente tem que render o tempo. A gente aprende a render o tempo... E com o tempo eles [alunos] entram no ritmo...". É válido lembrar que nesta aula a turma contava com 28 alunos. De certa forma, é possível concluir que esta aula rendeu mais porque os alunos possuíam o material, no caso, o livro 
didático. Assim, vê-se quão importante é o uso do material didático nas aulas de Helena. Fernández (2010, p. 76) descreve o caso de Helena, quando afirma que muitos professores "tienen una cantidad excesiva de clases semanales y poco tiempo disponible para dedicarse a la planificación (...), para algunos docentes la mejor solución - cuando no la única - sea la de optar exclusivamente por el seguimiento del libro de texto".

Por fim, é positivo notar o incentivo aos alunos para investir e dedicar-se ao vestibular e ENEM, mas, ainda assim, poucos estavam decididos a prestar o vestibular.

\section{OBSERVAÇÃO 2}

PARANOÁ: Nesta aula a professora começou a explicar o Pretérito Perfeito do Subjuntivo. Magali explica o tempo perguntando aos alunos como ficariam as conjugações e os alunos foram respondendo. A professora começa a ler a explicação do tempo verbal, mas os alunos começam a conversar. Iniciam a fazer a atividade, e os alunos começam a fazer perguntas sobre o exercício e o tempo verbal. A professora vai respondendo com tranquilidade e atendendo aos alunos individualmente.

Magali faz a chamada e alguns alunos respondem em Espanhol. Continuam o exercício e alguns ajudam os outros a resolver. Entretanto, ainda assim, há alguns alunos desinteressados. Logo, em seguida, a professora começa a falar do vestibular, e os alunos tiram suas duvidas sobre o assunto. Após essa conversa Magali inicia a correção, toda em Espanhol. A professora vai corrigindo e dá atenção maior aos exercícios em que os alunos tiveram maior dificuldade. Trata-se de uma correção interativa, visto que os alunos são participativos e Magali dá liberdade para que eles pensem e respondam. Magali escreve a palavra "tal vez" no quadro, e ouço uma aluna perguntar baixinho para si mesma: "por que em Espanhol talvez é separado?. Alguns alunos repetem o que a professora fala, na tentativa de pronunciar a palavra corretamente. A maioria da turma presta atenção até o fim da correção e, ao final, Magali diz que na próxima aula começarão a trabalhar o Pretérito pluscuamperfecto.

Esta aula de Magali também foi produtiva. A professora iniciou um novo tempo verbal, por meio de explicação e exercícios no livro. Percebi que quando a professora começou a ler o conteúdo os alunos logo se dispersaram. Contudo, como afirmou Leffa (2005), muitas vezes o aluno aprende apesar da metodologia "inadequada" do professor. Neste caso, ainda que os alunos não gostem quando a professora lê o conteúdo, não são prejudicados em seu aprendizado, pois muitos demonstram bom conhecimento de Espanhol ao responderem as perguntas e se engajarem na explicação e resolução dos exercícios. Refletindo sobre o porquê de Magali ler a explicação do conteúdo, concluo que talvez seja pelo fato de esta professora sempre ter dado aulas para $1^{\circ}$ e $2^{\circ}$ ano e ser a primeira vez que ministra aulas para $3^{\circ}$ ano, como ela mesma me relatou: "terceiro eu tenho que estudar (...). É puxadinho... Mas é bom, é bom a gente mudar”. 
Cabe ressaltar de maneira positiva as tentativas dos alunos de oralmente "imitar" a professora na pronúncia, e a reflexão de uma aluna ao questionar-se sobre a estrutura de uma palavra em Espanhol, confirmando que aprender abarca "a reflexão sobre o sistema da língua e a comunicação, sobre o sistema fonético e as habilidades necessárias...” (DIAS, 2014, p. 7). Por fim, também de forma positiva, diferente de alguns alunos de Taguatinga, nesta turma se vê o interesse pelo vestibular, constatado nas perguntas e dúvidas geradas pelos alunos.

\section{OBSERVAÇÃO 3}

TAGUATINGA: A turma está cheia. A professora diz que na última aula passou um exercício e apenas três alunos tinham feito. Helena pergunta se alguém deseja mostrar a ela esses exercícios nesta aula e poucos alunos se manifestam. A professora começa a falar das notas do bimestre e avisa que na próxima aula farão um exercício de compreensão oral valendo nota. Em seguida, rapidamente relembra o esquema gramatical da aula passada e inicia a correção do exercício. A turma permanece calada, somente uma aluna interage com a professora. Helena prossegue sua explicação, mas perde a paciência com quatro alunos e os retira da sala. A professora está muito aborrecida nesta aula, em função do comportamento e desinteresse dos alunos.

Após a saída dos quatro meninos, Helena volta à explicação e resolve os exercícios junto com os alunos, dando dicas e tirando as dúvidas com atenção. Em seguida, deixa os alunos resolvendo o exercício e faz a chamada. Passa pelas carteiras para tirar dúvidas, mas alguns alunos nem abriram a mochila.

A aula está acabando e poucos alunos mostraram o exercício para Helena.

Nesta aula fica evidente o aborrecimento de Helena em relação ao mau comportamento dos alunos e ao grande desinteresse demonstrado, ao ponto da professora colocar quatro alunos para fora da sala. Neste dia, Helena me disse: "É complicado, $e$ realmente a gente não sabe o que fazer mais. É pouco tempo e eu tento diversificar um pouco, essas duas últimas semanas eu tenho ficado mais "assim” porque na outra semana é prova já, e eles não estão nem um pouco preocupados!’. Logo, ainda que Helena se aborreça em sala, também se preocupa com a nota dos alunos, e confessa: "Eu tenho muito medo de não dar certo (...). O que é que eles precisam? É... É isso que a gente se pergunta (...). Porque a gente se pergunta mesmo, né, o que é que "tá" fazendo, o que não "tá”, e faz o possível, porque você vê que é bem corrido...".

Infere-se dessa fala que Helena é uma professora reflexiva, uma vez que este tipo de docente "é capaz de pensar sobre sua prática, confrontando suas ações e aquilo que julga acreditar como correto para sua atuação profissional com as consequências a que elas conduzem" (FONTANA e FÁVERO, 2013, p. 3). Logo, o questionamento, os temores e a 
insegurança no trabalho docente fazem parte da reflexão, do "olhar no espelho" que deve nortear a prática do professor, visto que "não existe conhecimento pronto, acabado, pois tudo é processo contínuo de construção e de autoconstrução.” (IBIDEM, 2013, p. 4).

\section{OBSERVAÇÃ̃O 3}

PARANOÁ: Hoje os alunos estão muito agitados. Falam alto e riem. A professora inicia a aula falando em Espanhol, já começa a explicar o Pretérito pluscuamperfecto, lê a explicação e faz observações. Inicia o exercício oralmente e os alunos começam a se concentrar. Praticamente toda a turma faz o exercício.

Em seguida, Magali começa a olhar as páginas que trabalharam na aula passada: da p. 45 até a p. 49. Após conferir as páginas, entrega aos alunos o conto "Lejos de casa", de Lourdes Miguel y Neus Sans. O material está impresso em 8 páginas, e os alunos devem iniciar a leitura nesta aula e terminar em casa, se preciso. Logo, os alunos ficam livres para a leitura, contudo, a maioria conversa entre si. O tempo vai passando e os alunos não fazem praticamente "nada": riem alto, brincam. Magali somente confere as atividades nos livros e pede silêncio apenas para fazer a chamada, e assim a aula transcorre até terminar.

Ainda que os alunos estivessem agitados nesta aula, a maioria se concentrou e foi participativa. É válido ressaltar que a professora fala em Espanhol praticamente o tempo inteiro. Perguntei a ela se os alunos "estranhavam", e ela respondeu: "Não estranham. Pra eles já é normal chegar falando em Espanhol... Claro que eles gostam quando explica em Português (...), às vezes eles não entendem, aí eles perguntam e a gente fala de novo (...). $2^{\circ} e$ $3^{\circ}$ [anos], eles já tem uma certa facilidade”.

Infelizmente, isso não ocorre nas aulas de Helena em Taguatinga, pois toda a aula é ministrada em Português, já que as condições não tornam esta atitude viável. Assim, o contato dos alunos de Taguatinga com o Espanhol é superficial, pois ouvem a língua apenas quando a professora lê e explica. Já os alunos do Paranoá são acostumados com a língua-alvo: os segundos e terceiros anos tem uma facilidade maior, pois já têm todas as suas aulas ministradas em Espanhol desde o primeiro ano.

Convém destacar que a professora conferiu todas as páginas que haviam trabalhado na aula anterior: 5 páginas completas de exercícios em somente uma aula. Enquanto Helena em Taguatinga lutava para terminar uma página completa em função do pouco tempo, Magali com tranquilidade resolveu com seus alunos 5 páginas de exercícios.

Por fim, os alunos receberam um material de leitura de fácil compreensão e enredo chamativo. Ainda que grande parte dos alunos não tenha se animado com a leitura, a eles é dada a oportunidade de ler na língua-alvo e conhecer parte da literatura e cultura, uma vez que 
"as culturas podem usar a linguagem oral, escrita e ações não-verbais como símbolos" (ORTÍZ ALVAREZ, 2010, p. 123). No material há ricas manifestações culturais: referência a festas regionais; expressões idiomáticas, lugares e datas comemorativas, explicadas também de forma clara em notas ao fim do texto.

Mais uma vez, o ponto negativo desta aula foi a utilização do tempo, pois do meio da aula até o término os alunos ficaram ociosos e com muito tempo livre.

\section{OBSERVAÇÃO 4}

TAGUATINGA: $\mathrm{Na}$ aula de hoje Helena aplicará um exercício de compreensão oral ${ }^{113}$ em dupla que valerá nota. Os alunos entram e demonstram surpresa: "eita lasqueira, hoje tem prova!", "ah é, hoje tem prova!'. Uma aluna chega e fala: "Bom dia! Como é bom dia em Espanhol?", a professora responde. Após isso, diz que olhará pela última vez o exercício da aula passada, e muitos alunos finalmente mostram à professora como fizeram o exercício.

Em seguida, Helena entrega para as duplas o exercício avaliativo, dá as orientações e passa para o exercício de compreensão oral. Os alunos estão quietos, lendo, tentando compreender. Ainda que seja um exercício pequeno de 10 questões, julguei difícil para o nível de conhecimento dos alunos, o que fez com que muitos desistissem de marcar corretamente. A professora passa o texto no aparelho de som mais duas vezes, e ao terminar, os alunos já podiam sair. Helena pergunta se querem ouvir novamente, mas os alunos dizem que não.

Por fim, Helena diz aos alunos que eu preciso conversar com eles em outra aula para aplicar o questionário. Alguns alunos pedem que seja aplicado na aula de "PI". Um aluno diz: "o que ele dá [o professor] na aula de história é a mesma coisa que ele dá na aula de PI!'”. Após esse momento, a aula acaba.

Inicialmente, ficou evidente que os alunos "não sabiam" do exercício avaliativo, apesar de Helena ter avisado sobre ele na aula anterior. Também, mais uma vez se percebe a lacuna no ensino de Espanhol para uma aluna, que, no $3^{\circ}$ ano do Ensino Médio, perguntou como se falava "Bom dia" em Espanhol. Refletindo sobre as possíveis causas para essa falta de conhecimento, é provável que Helena tenha me respondido quando afirmou que: "o que se cobra do Espanhol no Ensino Médio é algo quase impossível, porque os meninos não tem noção do Espanhol (...). Aí um menino que viu 45 minutos de aula durante um ano, uma vez por semana, ele não alcança isso. Ele não alcança”.

Sobre o exercício de compreensão oral, me pareceu muito difícil para o nível dos alunos. Isso ficou perceptível em suas reações: semblantes confusos, olhares duvidosos, ou seja, não estavam entendendo nada. Alguns nem tentaram marcar o exercício ao passo em que

${ }^{113}$ Anexo I. 
outros acharam graça da situação. Talvez muitos não tenham compreendido a maioria das palavras que ouviram, não pelo grau de dificuldade do exercício, mas porque geralmente não têm o input suficiente na LE.

É notável a observação de um aluno ao referir-se à disciplina PI (Projeto Interdisciplinar, semelhante ao PD), pois afirma que o professor nesta aula ministra o conteúdo da própria disciplina, reafirmando a má utilização desses horários de PI/PD.

\section{OBSERVAÇÃO 4}

PARANOÁ: Magali inicia a aula perguntando aos alunos se tinham feito a leitura da aula passada, e a maioria responde que não. Assim, a professora deu 20 minutos para que lessem o material antes de iniciar a atividade. Poucos alunos de fato leram, a maioria, desinteressada, ficou conversando e rindo. Após um tempo, Magali começa a fazer perguntas sobre o texto e poucos alunos sabiam respondê-las. A professora tenta conduzir um diálogo, mas a turma está muito barulhenta e demora a se acalmar, até finalmente, dar atenção ao texto.

Os alunos se dividem em duplas e recebem um questionário ${ }^{114}$ sobre o texto. Após a explicação de Magali os alunos iniciam a atividade, mas têm dificuldades com a primeira questão. Para ajudá-los, Magali faz a leitura do Capítulo 1. Os alunos, finalmente, se aquietam e se concentram na atividade, inclusive, muitos permanecem assim até o fim da aula. Ao término da aula, percebi que todas as respostas dos alunos estavam escritas em Espanhol.

$\mathrm{Na} 4^{\mathrm{a}}$ observação desta turma, como em Taguatinga, os alunos também fizeram atividade avaliativa, e a falta de interesse inicial foi a mesma nos alunos das duas RAs, tendo em vista que a maioria dos alunos na EP1 não havia lido o material da aula passada. Cabe recordar que tiveram praticamente a aula passada inteira para ler e inclusive levaram o material para casa. Contudo, como ficaram muito "livres" na aula passada, não leram o material e o tempo foi desperdiçado. Os alunos desta turma costumam ser muito barulhentos, porém fazem silêncio quando a professora pede. Entretanto, nesta aula estavam muito agitados e desinteressados, e ficaram quietos somente para fazer a atividade que valia nota.

Convém salientar que sem a professora pedir, praticamente todos os alunos colocaram as respostas em Espanhol. Isso me pareceu positivo, pois pelo que pude ver, a maioria das respostas estava correta. Sobre isso, Magali afirmou: "Sim, claro! Tudo em Espanhol! (...). As coisas que nós já vimos, eles já não podem errar mais. Eles não falam, mas eles escrevem na língua”. Assim, penso que essa capacidade é desenvolvida também em função das leituras que a professora realiza em sala. Esse é o segundo conto que a turma tinha lido este ano, e

\footnotetext{
${ }^{114}$ Anexo K.
} 
ainda que eles não se interessem em um primeiro momento, pelo menos para fazer o exercício, leem. Percebo que esta turma desenvolve a "compreensão leitora", citada pelas OCENS (2006) como uma atividade que objetiva "levar à reflexão o texto lido: mais além da decodificação do signo linguístico...” (MEC/SEB, 2006, p. 151), uma vez que mais que ler e compreender, os alunos necessitaram julgar itens referentes ao que leram.

A leitura e a atividade relacionada ao material de leitura trabalhado nesta turma da EP1 teve dois encontros de 1h30min cada, ou seja, uma semana. Nas condições de Taguatinga, esta atividade necessitaria, pelo menos, de 3 aulas: 2 para a leitura do material (em sala) e 1 para realizar a atividade escrita, em total: 3 semanas. Dessa maneira, infelizmente noto uma discrepância entre a quantidade de conteúdo e oportunidade de trabalhar outras habilidades no Paranoá em relação ao que é possível em Taguatinga.

\section{OBSERVAÇÃO 5}

TAGUATINGA: A turma está cheia e os alunos estão tranquilos, quietos, trabalhando em duplas. Hoje farão um exercício ${ }^{115}$ avaliativo para o $3^{\circ}$ bimestre. Helena explicou o exercício muito bem: o exercício é sobre profissões, e para realizá-lo cada dupla possui um dicionário cedido pela escola. Enquanto os alunos fazem a atividade, a professora os incentiva: "Vamos lá, se não, não dá tempo!".

Em seguida, Helena começa a ler as notas do $2^{\circ}$ bimestre, e a maioria da turma não passou em Espanhol, sendo que os que passaram obtiveram nota 5 ou 6 . A nota mais alta foi 7. A professora diz a aos alunos que as notas foram baixas simplesmente porque eles não fizeram os exercícios em sala. Os alunos não contestam, na verdade, parecem não se importar muito com as notas abaixo da média.

Os alunos prosseguem realizando a atividade, ajudando uns aos outros, tirando dúvidas com a professora e por fim, começam a entregar a atividade a Helena.

Esta aula foi uma das mais tranquilas que observei nesta turma, uma vez que os alunos estavam quietos e fizeram a atividade. O exercício sobre profissões me pareceu muito simples para uma turma de $3^{\circ}$ ano, pois este é um vocabulário que se costuma trabalhar no $1^{\circ}$ ano do Ensino Médio. Neste dia, Helena me disse que não gosta do livro didático adotado, pois o considera muito avançado para seus alunos. Por isso, trouxe atividades extras em folhas para realização em dupla. Segundo ela, os alunos costumam fazer mais esse tipo de atividade, contudo, ela não tem condições de trazer exercícios em folhas toda semana, pois possui 1.200 alunos, logo, o custo com cópias seria muito alto. Nisso, percebe-se a escassez de recursos.

Enquanto os alunos faziam o exercício, estava presente a constante preocupação de Helena com o pouco tempo, ao alertar os alunos para que não se dispersassem.

\footnotetext{
115 Anexo J.
} 
Acerca das notas baixas, justifico esse resultado pelo desinteresse do aluno pela disciplina. Helena é uma profissional dedicada e faz o possível para motivar seus alunos. Porém, há que se confessar que as condições na qual a disciplina é oferecida (pouco tempo de aula; uma vez por semana, pouco contato com a língua, dificuldade para realizar alguma atividade "diferente" - na sala há televisão, porém ainda assim, o pouco tempo não contribui para que "ouvir uma música" ou "assistir a um filme" seja uma atividade viável) não contribuem para que os alunos compreendam o Espanhol como uma disciplina com a qual devam se preocupar. Para eles o Espanhol ainda é uma língua "fácil”, pois, caso pudessem ter um aprofundamento maior no estudo da língua, veriam que o Espanhol "es difícil, correcto, detallista, redundante, complicado, rebuscado, formal, mandón" (CELADA e RODRIGUES, 2005, p. 8). Ao comentar sobre o desinteresse de seus alunos nesta aula, Helena inclusive emocionou-se e chorou, dizendo que faz o que está ao seu alcance para motivá-los, ainda que seja difícil. Ainda sobre isso, segundo Félix (1998) existe um círculo vicioso no ensino de línguas: o aluno desinteressado age a fim de que o professor espere pouco e cobre pouco dele. Tal atitude leva ao baixo desempenho. Este baixo desempenho deixa o professor desestimulado, sendo essa falta de estímulo do professor, uma contribuição para que o aluno não se interesse pelo estudo da língua. Logo, é possível que este círculo vicioso esteja presente entre os alunos desta turma, já que muitos tiveram baixo desempenho.

\section{OBSERVAÇÃO 5}

PARANOÁ: Cheguei à escola mais cedo, cerca de 40 minutos antes do início da aula. Chegar cedo foi providencial, pois a escola decidiu naquela manhã "compactar os horários", assim, a turma já estava em sala havia mais ou menos meia hora, e ainda teria meia hora de aula. Quando cheguei à sala os alunos estavam sozinhos, com os livros abertos resolvendo exercícios. A professora já havia explicado o conteúdo e passado as atividades.

Neste dia Magali começou a trabalhar o Imperativo, e os alunos resolviam exercícios de duas páginas do livro: 63 e 64, juntamente com uma folha ${ }^{116}$ sobre o mesmo tema. Enquanto resolviam os exercícios os alunos brincavam tentando falar frases em Espanhol. A professora voltou próximo de o horário tocar para o término daquela aula. Magali fez a chamada, conversou com os alunos, tirou algumas dúvidas e a aula acabou.

A turma do Paranoá teve uma aula um pouco menor em função da compactação de horário, contudo, ainda assim iniciaram um novo conteúdo. É necessário salientar que esta turma estudou três tempos verbais desde que as observações iniciaram, ao passo que os alunos

\footnotetext{
${ }^{116}$ Anexo L.
} 
de Taguatinga puderam ver somente aspectos básicos, como exercícios de vocabulário e pontos mais simples de gramática. Sobre isso, Magali diz: "Conteúdo dá pra gente ver bastante (...). Dá tempo até de trazer coisas extras, não trabalhar só o livro, porque (...) imperativo que a gente "tá" vendo agora no livro "tá" bem... [simplificado] e não dá pra eles... Aí vou tentar tirar cópia e trazer pra eles...".

Convém destacar que os alunos do Paranoá tentam falar em Espanhol, ainda que entre uma brincadeira ou outra entre eles, ou para imitar as palavras pronunciadas pela professora. Todavia, segundo Magali não há como trabalhar a oralidade de maneira produtiva, tendo em vista o elevado número de alunos em sala: "Se pedir pra ler eles já leem, eles querem falar, então assim, o que eu acho difícil na oralidade deles é que, por exemplo, uma turma de 45 alunos (...), ai você trabalha com 5... se passar disso já fica enjoativo, já fica cansativo...”. Portanto, para a professora é possível trabalhar a oralidade somente com turmas de em média, 15 alunos, como acontece nos Centros de Línguas. Ainda que de fato, trabalhar a oralidade de maneira eficaz com 45 alunos seja algo difícil em um encontro de 1h30min, enxergo que o pensamento: "trabalhar oralidade somente é possível com turmas de 15 alunos" pode se constituir numa crença da professora, pois na EP1 há outras professoras que trabalham a oralidade de seus alunos em sala. Segundo elas não é fácil, mas é possível.

Sobre essa questão, segundo Silva (2008, p. 208, grifo meu), as crenças envolvem o "dizer e o fazer dos sujeitos inseridos num contexto social micro (sala de aula, por exemplo)...", como se vê em Magali, que acredita e afirma não ser possível trabalhar oralidade com seus alunos e isso se reflete em sua ação, visto que de fato, não o faz.

\section{OBSERVAÇÃO 6}

TAGUATINGA: Hoje a turma está cheia, com 26 alunos. Helena começa a abordar um novo conteúdo: "Preposiciones", e afirma que este é o conteúdo do próximo exercício avaliativo. Explica a matéria e alguns alunos prestam atenção, enquanto outros conversam ou estão dispersos. Ainda assim, a sala está bastante silenciosa. Após a explicação do conteúdo, Helena passa o exercício do livro para que os alunos façam. A maioria está com o livro nesta aula, e realmente começa a fazer o exercício. A professora saiu da sala por um momento e muitos deles prosseguem concentrados no exercício.

Helena retorna à sala e faz a chamada, enquanto os alunos ainda resolvem as duas páginas de exercícios. Após um tempo, uma fila se forma na mesa de Helena para mostrar à professora os exercícios feitos. Os alunos que terminaram vão saindo, enquanto Helena arruma as fileiras das carteiras para a chegada da próxima turma.

Esta aula foi no $3^{\circ}$ bimestre, após o recesso escolar, e nela há uma nítida mudança de 
comportamento dos alunos, uma vez que a maioria prestou atenção na explicação, trouxe o livro, fez a atividade e ainda mostrou para a professora. Concluo que esta mudança de comportamento dos alunos foi uma tentativa de recuperar e ganhar nota, já que no bimestre passado grande parte da turma não trazia o livro e não fazia os exercícios, resultando em notas baixas. Dessa maneira, é perceptível associar o comportamento do aluno a seus próprios interesses. Mesmo percebendo isso, Helena se esforça para que os alunos de fato compreendam o conteúdo, e afirma para mim: “... É de pouquinho em pouquinho, é um trabalho de formiguinha...". Ao longo das observações, nota-se que esta turma realizou exercícios do livro didático ou exercícios trazidos em folhas, ou seja, exercícios de ordem estrutural. Assim, compreendo que tanto Helena como Magali têm abordagem gramatical, o que pode ser uma das causas para o desinteresse de alguns alunos.

Observei que Helena não trabalhou aspectos culturais nas aulas observadas. Porém, a professora me contou que em uma aula do bimestre anterior a turma trabalhou as festas típicas espanholas, e assim, pretendia que eles apresentassem oralmente sobre essas festas, entretanto, confessou: "mas aí eu desisti dessa apresentação, porque 45 minutos, muito corrido, fica muito atropelado”. Logo, ainda que se trabalhe aspectos culturais da língua, a pouca carga horária também não contribui para que este trabalho seja de fato, efetivo. Portanto, como bem afirmaram Lima e Ortíz Alvarez (2011, p. 69, grifo meu), "os malentendidos dos alunos de Espanhol como Língua Estrangeira (E/LE) são, muitas vezes, resultado do desconhecimento tanto dos fatos linguísticos como dos culturais".

\section{OBSERVAÇÃO 6}

PARANOÁ: A aula iniciou com a correção da folha com exercícios do Imperativo trabalhada na aula passada. Magali pergunta as respostas e os alunos vão respondendo corretamente. Alguns repetem as conjugações oralmente mais de uma vez, enquanto Magali vai corrigindo e explicando ao mesmo tempo. A maioria da turma está atenta à correção, porém ainda há alunos dispersos e rindo.

Após a correção da primeira parte da folha, Magali começa a corrigir a segunda parte. Os alunos vão tentando construir frases na língua e ao mesmo tempo, se divertem. Magali sorri. Em certo momento Magali fala comigo em Português, e logo é questionada pelos alunos: "Por que você falou com ela em Português e com a gente você só fala em Espanhol?".

Após essa correção, Magali entrega uma segunda folha ${ }^{117}$ sobre o imperativo negativo. A professora explica muito rapidamente o esquema gramatical enquanto alguns alunos leem a folha tentando compreender. Magali faz a chamada e deixa os alunos livres para iniciarem a resolver os exercícios. Os alunos fazem, conversam, se ajudam, alguns tiram duvidas com a professora, e assim a aula transcorre até o final.

\footnotetext{
${ }^{117}$ Anexo M.
} 
De maneira inicial, cabe destacar minha surpresa nesta aula ao perceber que os alunos desta turma, de fato, pareciam saber o Imperativo em Espanhol, uma vez que conjugavam perfeitamente os verbos durante a correção. Trata-se de um tempo verbal que apresenta dificuldades entre os alunos, mas mesmo assim os alunos se saíram muito bem. Mais uma vez ficam evidentes as tentativas dos alunos de produzirem frases na língua-alvo por meio de repetição de palavras e brincadeiras. Magali se sente satisfeita com essas tentativas, mas ainda assim, é resistente quanto a trabalhar e avaliar a oralidade de seus alunos em suas aulas de Espanhol. Tal postura parece confirmar a hipótese de que Magali é uma professora gramaticalista, porém mesmo assim, fala em Português poucas vezes com seus alunos, sendo que os mesmos estranham e chegam a questionar o fato dela ter falado em Português comigo.

Além de ter corrigido uma folha inteira de exercícios gramaticais, Magali entrega aos alunos uma segunda folha a fim de trabalhar o Imperativo Negativo, porém o explica de maneira muito simplificada. Notei que muitos alunos leram a folha com atenção, buscando realmente compreender o esquema gramatical trabalhado. Mais uma vez os alunos ficam de certa maneira "livres" para resolver os exercícios da folha entregue. Percebo que algumas vezes Magali não otimiza o tempo de suas aulas. Analisando e comparando as duas turmas, me perguntei diversas vezes o que Helena faria em suas aulas caso tivesse a mesma carga horária que Magali, uma vez que Helena faz seu tempo de aula render, e Magali às vezes não utiliza todo o tempo que tem disponível.

Em função das três intervenções ocorridas em Taguatinga, observei no Paranoá três encontros a mais. Pelos fatos ocorridos nessas três observações, julguei necessário elencá-las nesta dissertação. Logo, de forma breve relato a seguir essas três observações realizadas no Paranoá:

\begin{tabular}{|l|l|}
\hline \multicolumn{2}{|c|}{ PARANOÁ } \\
\hline OBSERVAÇÃO 7 & $\begin{array}{l}\text { Magali chega à sala segurando muitas folhas na mão e diz: "Hoje } \\
\text { nós vamos resolver uma prova do vestibular da UnB". Uma aluna } \\
\text { contesta: "De novo?", e Magali responde: "De novo!". } \\
\text { A professora entrega a prova de Espanhol de um vestibular da UnB } \\
\text { de 2006 } \\
\text { (inclusive aqueles que costumam "bagunçar") estão concentrados, } \\
\\
\text { com a cabeça baixa, resolvendo a prova de Espanhol do vestibular } \\
\text { da UnB. Meia hora depois os alunos ainda permanecem em silêncio } \\
\text { profundo, concentrados na prova. Alguns chamam Magali e esta vai } \\
\text { até a carteira, outros vão à sua mesa. Quase ao término da aula, após }\end{array}$ \\
\hline
\end{tabular}

\footnotetext{
${ }^{118}$ Anexo N.
} 


\begin{tabular}{|c|c|}
\hline & $\begin{array}{l}\text { a maioria dos alunos entregar a prova, Magali anota no quadro os } \\
\text { números das questões do exercício que fizeram na aula passada para } \\
\text { realizar a correção, mas o sinal bate. }\end{array}$ \\
\hline OBSERVAÇÃO 8 & $\begin{array}{l}\text { Hoje o horário é compactado, logo, será de apenas } 50 \text { minutos. Ao } \\
\text { chegar à sala os alunos estavam sozinhos, e sobre a mesa da } \\
\text { professora havia provas do ENEM 2013, às quais alguns alunos } \\
\text { olhavam com interesse. Magali chegou logo em seguida com outras } \\
\text { provas do ENEM e disse: "Quem quer as provas do segundo dia?", } \\
\text { e grande parte dos alunos disse: "Euu!", indo rapidamente à mesa da } \\
\text { professora. Cada aluno ficou, em média, com duas provas do } \\
\text { ENEM. Os alunos folheiam as provas, leem, comentam, alguns } \\
\text { conversam com Magali. Em seguida, um grupo observa exemplos de } \\
\text { redação, e começa a apontar os erros: "Eu acho"... A professora } \\
\text { pergunta: "O que há de errado?, e eles respondem: "Eu não acho } \\
\text { nada!". Uma aluna comenta: "o "provão" "tava" mais difícil que o } \\
\text { ENEM!", e assim, a turma prossegue comentando as provas. } \\
\text { Magali não passou mais nenhum exercício, deixando toda aula para } \\
\text { análise e resolução das provas do ENEM } 2013 \text {. }\end{array}$ \\
\hline OBSERVAÇÃO 9 & $\begin{array}{l}\text { Hoje é o último dia antes das provas, portanto, trata-se de uma aula } \\
\text { de revisão. A professora iniciou a revisão com exercícios sobre } \\
\text { Imperativo negativo, e começou a comentar como seria a prova de } \\
\text { Espanhol: um pouco menor que as demais, mas com questões } \\
\text { subjetivas. Em seguida, entrega aos alunos uma folha }{ }^{119} \text { para } \\
\text { resolverem em sala com todos os tempos verbais trabalhados no } \\
\text { bimestre: pretérito imperfeito do subjuntivo; pretérito perfeito do } \\
\text { subjuntivo, pretérito pluscuamperfecto do subjuntivo, imperativo } \\
\text { afirmativo e negativo. A aula é inteiramente dedicada à resolução } \\
\text { desta folha. }\end{array}$ \\
\hline
\end{tabular}

A $7^{\mathrm{a}}$ e a $8^{\mathrm{a}}$ aula observadas apresentaram elementos semelhantes entre si: ambas destinaram-se à resolução de provas que visam à entrada na universidade. De maneira muito positiva, é possível perceber que na EP1 os alunos são muito incentivados a sonhar com uma vaga em universidades públicas, e tem o suporte necessário para não ficarem aquém das escolas particulares, uma vez que têm a oportunidade de resolver provas de vestibular em sala com o auxílio da professora para atendê-los de maneira individual. Cabe salientar que praticamente toda a turma se concentrou na resolução das provas, inclusive os alunos que costumam ser indisciplinados, demonstrando real interesse e vontade. Infelizmente, refleti sobre os alunos de Taguatinga, que na verdade têm a sua realidade longe disso, visto que mal realizam os exercícios do livro didático e veem uma carga de conteúdo consideravelmente menor que os alunos do Paranoá.

Também observo que no Paranoá não há um ensino facilitado da língua uma vez que

\footnotetext{
${ }^{119}$ Anexo O.
} 
os alunos são expostos a diversos conteúdos em um bimestre, ao ponto de uma aluna afirmar que o "provão" da escola estava mais difícil que a prova do ENEM. Não são conteúdos simplificados ou listas de vocabulários: trata-se de tempos verbais complexos que Magali trabalhou tanto a conjugação dos verbos regulares, como dos irregulares.

Finalmente, conversando com Magali a respeito do aumento de carga horária, a professora afirma: "Dá pra dar uma continuidade ao trabalho. Então agora "tá" muito melhor. Mas nos primeiros anos foi bem complicado...". É visível a continuidade e a conexão entre o conteúdo e as aulas dadas, pois Magali sempre retoma o assunto da aula anterior com uma resolução de exercícios inicial, até chegar ao conteúdo que norteará o restante da aula.

\subsection{A visão dos alunos: O questionário}

Após a demonstração de como se dá a vivencia escolar das duas turmas aqui analisadas, o último tópico desta análise de dados diz respeito à visão do aluno em relação ao ensino de Espanhol, uma vez que o aluno é (ou deveria ser) o ator principal da comunidade escolar. Captei a visão dos alunos por meio de um questionário ${ }^{120}$ aplicado às duas turmas. Este questionário foi aplicado e preenchido por 25 alunos na turma de Taguatinga e por 35 alunos na turma do Paranoá, e consistiu nas seguintes perguntas:

Quadro 8 - Perguntas do Questionário - alunos

1. É importante estudar Espanhol na escola? Por quê?

2. Você já estudou (ou estuda) Espanhol fora da escola? Se sim, onde e durante quanto tempo?

3. Em sua visão, qual é o seu conhecimento de Espanhol desde o primeiro ano do ensino médio até agora?

a) Nenhum b) Pouco c) Razoável d) Mediano e) Acima da media f) Excelente

4. Em sua opinião, é possível aprender Espanhol na escola? Por quê?

5. Você gosta de ter aulas de Espanhol na escola? Acredita que suas aulas são motivadoras? Por quê?

6. O que te deixa motivado nas aulas de Espanhol?

7. O que te deixa desmotivado nas aulas de Espanhol?

8. Como você gostaria que fossem suas aulas de Espanhol?

9. Você acredita que o tempo para as aulas de Espanhol na sua escola é suficiente para estudar a língua? Por quê?

10. Qual será a sua língua de opção no vestibular/PAS/ENEM? Por quais motivos você escolheu esta língua?

Fonte: autoria própria

Portanto, a seguir apresento os excertos e análise das respostas obtidas.

${ }^{120}$ Apêndice G. Convém lembrar que os alunos assinaram termos de consentimento de participação da pesquisa. 


\subsection{1 É importante estudar Espanhol na escola? Por quê?}

As respostas entre os alunos de Taguatinga e Paranoá foram muito semelhantes. A maioria dos alunos acredita que é importante estudar Espanhol, pois é um conhecimento a mais que se ganha, como se vê nos relatos abaixo:

\begin{tabular}{|l|l|}
\hline \multicolumn{1}{|c|}{ TAGUATINGA (7 alunos) } & \multicolumn{1}{|c|}{ PARANOÁ (17 alunos) } \\
\hline $\begin{array}{l}\text { 1. "Sim, porque é o conhecimento de uma } \\
\text { nova língua". }\end{array}$ & $\begin{array}{l}\text { 1. "Sim, porque há o conhecimento de } \\
\text { outras línguas". }\end{array}$ \\
\hline $\begin{array}{l}\text { 2. "Sim, porque é um conhecimento a a } \\
\text { mais". }\end{array}$ & $\begin{array}{l}\text { 2. "Sim, porque precisamos ter mais } \\
\text { conhecimento". }\end{array}$ \\
\hline $\begin{array}{l}\text { 3. "Sim, pois é bom conhecer outras } \\
\text { línguas". }\end{array}$ & $\begin{array}{l}\text { 3. "Sim, porque todo conhecimento é } \\
\text { bem-vindo". }\end{array}$ \\
\hline
\end{tabular}

Logo, é possível ver que muitos alunos têm a consciência de que aprender uma segunda língua significa obter conhecimento, e conhecimento sempre deve ser "bem-vindo".

A segunda motivação mais citada foi em relação ao mercado de trabalho:

\begin{tabular}{|l|l|}
\hline \multicolumn{1}{|c|}{ TAGUATINGA (5 alunos) } & \multicolumn{1}{|c|}{ PARANOÁ (8 alunos) } \\
\hline $\begin{array}{l}\text { 1. "Sim, pois é uma língua a mais no } \\
\text { currículo". }\end{array}$ & $\begin{array}{l}\text { 1. "Sim, ser bilíngue aumenta as chances } \\
\text { no mercado de trabalho". }\end{array}$ \\
\hline $\begin{array}{l}\text { 2. "Sim (...), porque é cobrado no } \\
\text { mercado de trabalho, e estas aulas são } \\
\text { oportunidade para quem não tem }\end{array}$ & $\begin{array}{l}\text { 2. "Sim, pois hoje quem domina outros } \\
\text { idiomas está à frente de outras pessoas". }\end{array}$ \\
\cline { 2 - 2 } $\begin{array}{l}\text { condição financeira boa para bancar um } \\
\text { cursinho". }\end{array}$ & $\begin{array}{l}\text { 3. "Sim, porque aprendemos uma língua } \\
\text { nova e isso valoriza o currículo". }\end{array}$ \\
\cline { 2 - 3 } & 4. "Sim, ajuda no mercado de trabalho". \\
\hline
\end{tabular}

Assim, muitos alunos consideram aprender Espanhol uma boa oportunidade para "estar à frente" das outras pessoas no mercado de trabalho, demonstrando que mesmo que muitos sejam desinteressados em sala, ainda assim, desejam um futuro bem-sucedido.

Outros alunos acreditam que é importante estudar Espanhol devido à importância da língua mundialmente, uma vez que o Espanhol cresceu de maneira considerável:

\begin{tabular}{|l|l|}
\hline \multicolumn{1}{|c|}{ TAGUATINGA (3 alunos) } & \multicolumn{1}{|c|}{ PARANOÁ (3 alunos) } \\
\hline $\begin{array}{l}\text { 1. "Sim, porque é a segunda língua mais } \\
\text { falada no mundo". }\end{array}$ & $\begin{array}{l}\text { 1. "Sim, pois é a segunda língua mais } \\
\text { falada no mundo". }\end{array}$ \\
\hline $\begin{array}{l}\text { 2. "Sim, pois é uma língua em ascensão e e } \\
\text { está se tornando muito importante para a } \\
\text { comunicação internacional". }\end{array}$ & $\begin{array}{l}\text { 2. Sim, porque precisamos de pelo } \\
\text { influente no mune sobre essa língua tão }\end{array}$ \\
\hline
\end{tabular}


Outros acreditam que é importante estudar outra língua além do Português (2 alunos em Taguatinga e 3 alunos no Paranoá) e por último, 3 alunos de Taguatinga acreditam que estudar Espanhol ajuda nas provas do vestibular e ENEM.

Contudo, alguns alunos não concordam que seja importante estudar Espanhol na escola: os alunos de Taguatinga justificam sua resposta pelo pouco tempo das aulas e os do Paranoá por não gostarem da metodologia utilizada pela professora:

\begin{tabular}{|l|l|}
\hline \multicolumn{1}{|c|}{ TAGUATINGA (5 alunos) } & \multicolumn{1}{|c|}{ PARANOÁ (4 alunos) } \\
\hline $\begin{array}{l}\text { 1. "Seria se o ensino fosse mais eficaz e } \\
\text { tivesse mais tempo". }\end{array}$ & $\begin{array}{l}\text { 1. "Não, pois não é bem aproveitada” [a } \\
\text { aula]. }\end{array}$ \\
\hline $\begin{array}{l}\text { 2. "Não, pois o Espanhol na escola não } \\
\text { nos ajuda, pois não temos muitas aulas". }\end{array}$ & $\begin{array}{l}\text { 2. "Não, porque as aulas não são bem } \\
\text { ministradas". }\end{array}$ \\
\hline
\end{tabular}

Alguns alunos de Taguatinga acreditam que estudar Espanhol na escola não é importante, pois, de fato, como julgar importante uma disciplina com uma carga horária menor em relação às demais? Nessas respostas mais uma vez se evidencia que a pouca carga horária contribui para a desvalorização da disciplina por parte do aluno: na escola não têm tempo para estudar a língua, e assim, não aprendem. Logo, "Espanhol não deve ser algo tão importante para se aprender", pensam alguns deles.

Em contrapartida, para alguns alunos do Paranoá as aulas de Espanhol não são bem aproveitadas e ministradas, pois acreditam que a metodologia da professora (Magali) é muito estrutural: muitos exercícios gramaticais, muita leitura e poucas atividades diferenciadas, como percebi nas respostas seguintes.

\subsubsection{Você já estudou (ou estuda) Espanhol fora da escola? Se sim, onde e durante quanto tempo?}

Somente um aluno de cada turma já havia estudado Espanhol fora da escola: Uma aluna de Taguatinga estava na primeira semana do curso de Espanhol no CILT, e um aluno do Paranoá estuda Espanhol no CIL 01 de Brasília, porém não disse há quanto tempo. Os demais alunos nunca estudaram Espanhol fora da escola. Esse dado se torna instigante principalmente em Taguatinga, uma vez que esta RA possui um Centro de Línguas (CILT) que atende os alunos da rede pública de ensino e oferece cursos de Espanhol. Por meio desse dado convém o questionamento: Até que ponto esses alunos são incentivados a estudar o Espanhol fora do ambiente escolar? 


\subsubsection{Em sua visão, qual é o seu conhecimento de Espanhol desde o primeiro ano do ensino médio até agora? a) Nenhum, b) Pouco, c) Razoável, d) Mediano, e) Acima da media, f) Excelente}

Esta pergunta apresentou algumas diferenças entre as duas turmas, como é possível observar na tabela abaixo:

Tabela 8 - Nível de conhecimento dos alunos

\begin{tabular}{|c|c|c|}
\hline Nível de conhecimento & TAGUATINGA & PARANOÁ \\
\hline Nenhum & 1 & 2 \\
\hline Pouco & 13 & 16 \\
\hline Razoável & 5 & 7 \\
\hline Mediano & 5 & 9 \\
\hline Acima da média & 0 & 0 \\
\hline Excelente & 0 & 0 \\
\hline
\end{tabular}

Fonte: Autoria própria

Pelos números observados na tabela acima, é possível observar que os alunos foram muito honestos em suas respostas. Nas duas turmas praticamente metade dos alunos assinalou a resposta "pouco". Com base nas observações feitas, considero que muitos alunos da turma de Taguatinga, de fato, têm pouco conhecimento de Espanhol. Contudo, não concordo que quase a metade da turma do Paranoá saiba pouco da língua, pois o comportamento e participação da maioria dos alunos em sala, a meu ver, não é condizente com essa resposta. Portanto, é possível que os alunos do Paranoá exijam mais de si mesmos, ou realmente acreditam que ainda sabem pouco da língua.

Em Taguatinga, 5 alunos julgaram ter conhecimento razoável, enquanto no Paranoá esse número sobe para 7. Da mesma forma, em Taguatinga 5 alunos acreditam ter um conhecimento mediano da língua, ao passo em que no Paranoá este número sobe para quase o dobro: 9 alunos. Cabe destacar que nas duas turmas nenhum aluno julgou seu conhecimento "acima da média" ou "excelente". Um aluno de cada turma não respondeu a essa pergunta.

\subsubsection{Em sua opinião, é possível aprender Espanhol na escola? Por quê?}

Esta é uma das principais perguntas, pois evidencia se para o aluno, de acordo com sua realidade, é possível aprender Espanhol na escola. Em Taguatinga, a turma ficou praticamente dividida: 14 alunos acreditam que não é possível aprender Espanhol na Escola, ao passo que 
11 acreditam que é possível. Dos 14 alunos de Taguatinga que afirmaram não ser possível aprender Espanhol na escola, 12 justificaram sua resposta em função da pouca carga horária:

\begin{tabular}{|l|}
\hline 1. "Não, porque aprendemos muito pouco e é pouco tempo de aula". \\
\hline 2. “... não há uma sequencia necessária para aprender". \\
\hline 3. "Não, porque o tempo não ajuda, pois as aulas são apenas de 50 min". \\
\hline 4. "Não, porque é pouco tempo para aprender, e quando aprendemos é o básico”. \\
\hline
\end{tabular}

Nas respostas acima os alunos afirmam que "o tempo não ajuda", não contribui para a aprendizagem, pois quando aprendem, aprendem pouco, aprendem o "básico". Os próprios alunos percebem que em função da pouca carga horária não há sequência entre as aulas, como foi evidenciado nas observações, uma vez que a cada aula, novos conteúdos eram apresentados aos alunos com pouca (ou nenhuma) recapitulação do que havia sido estudado na aula anterior. Essas falas coincidem com as falas dos professores de Taguatinga quando afirmam que com a pouca carga horária não é possível realizar um trabalho de qualidade, nem promover um aprendizado efetivo.

Em contrapartida, 11 alunos de Taguatinga acreditam que é possível aprender Espanhol na escola, pois têm bons professores que explicam o conteúdo. Mas, é possível aprender somente o básico e se o aluno tiver interesse:

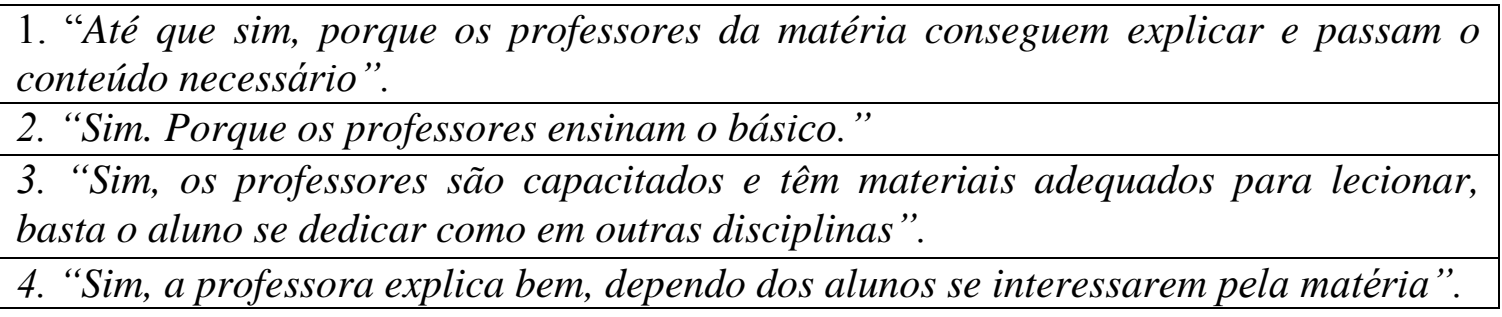

Infere-se pelas falas acima que esses alunos vinculam à aprendizagem a atuação do professor aliada ao interesse e dedicação do aluno. Logo, há o reconhecimento de que o êxito na absorção do conteúdo não depende somente do professor, da carga horária ou dos materiais disponíveis, mas também da responsabilidade que os próprios alunos devem ter em relação à disciplina, e os alunos (ainda que muitos sejam desinteressados) sabem disso.

Já no Paranoá, a diferença de opinião é maior: 26 alunos acreditam que é possível aprender Espanhol na escola, enquanto 9 alunos acreditam que não é possível por motivos diversos: o tempo para as aulas ainda é insuficiente, a aula não é bem aproveitada, falta de material, etc. 
É válido destacar que alguns afirmaram ser possível aprender Espanhol na escola porque vivem uma realidade diferente de outras escolas:

\begin{tabular}{l} 
1. "Sim, pois temos recursos que outras escolas não têm como livros, sala de vídeo, \\
televisores em cada sala e aparelho de som". \\
\hline 2. "Sim, porque aqui as aulas são maiores em relação às outras escolas". \\
3. "Sim, porque temos recursos".
\end{tabular}

Pelas respostas acima, nota-se que alguns alunos do Paranoá têm a consciência de que vivem uma realidade diferente em seu ensino de Espanhol, por razões que eles mesmos elencaram e julgam positivas para o aprendizado. Portanto, mesmo que em determinados momentos os alunos pareçam apáticos e sem interesse, ainda assim têm a percepção de que a realidade de ensino de língua espanhola que vivenciam é diferenciada.

Muitos alunos também enfatizaram que ainda que seja possível aprender Espanhol na escola, depende muito do professor e seu método de ensino, aliado à vontade e ao interesse em aprender por parte do aluno. Desse modo, segundo esses alunos do Paranoá, para que a aprendizagem de Espanhol aconteça, tanto o professor como o aluno deve ter interesse em ensinar e aprender, respectivamente:

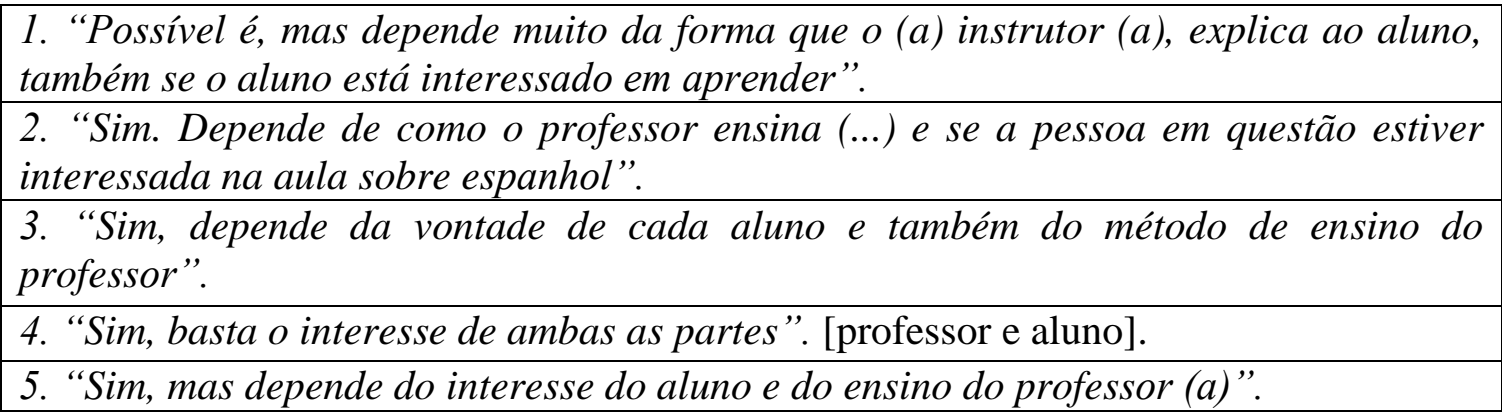

De acordo com as falas acima aliadas às aulas observadas nesta turma no Paranoá, inferi que alguns alunos não se identificavam com o método de ensino de Magali. Essa falta de identificação afeta diretamente o interesse do aluno, sua motivação e inclusive, a identificação do aluno com a própria língua-alvo, uma vez que ao ouvir falar sobre o "Espanhol”, é possível que os primeiros pensamentos que tenham sejam atrelados a suas aulas na escola, que consistem, geralmente, em exercícios estruturais e leitura, sem o trabalho da oralidade. Porém, é válido ressaltar que a aprendizagem se dá de maneira individual, uma vez que muitos alunos desta turma aprenderam a língua com o método de ensino utilizado pela professora, ao passo em que outros alunos, não. 


\subsubsection{Você gosta de ter aulas de Espanhol na escola? Acredita que suas aulas são motivadoras? Por quê?}

Ainda que vivam uma realidade que abarca dificuldades, 17 alunos de Taguatinga gostam de ter aulas de Espanhol, pois as aulas proporcionam novos conhecimentos e incentivam o estudo da língua. Contudo, nem todos acham as aulas motivadoras: alguns reclamam da falta de tempo, outros da falta de dinamicidade e de exercícios orais, assim como do pouco conteúdo. Quanto aos 8 alunos que afirmaram não gostar de ter aulas de Espanhol na escola, os motivos são diversos: não gostam da língua, creem que não aprendem nada, julgam a disciplina desnecessária, etc.

Na turma do Paranoá 23 alunos afirmaram que gostam das aulas de Espanhol. Alguns disseram que as aulas são motivadoras, pois abarcam conhecimento e curiosidade, porém muitos afirmaram que não se sentem motivados nas aulas em função do método de ensino utilizado pela professora. Logo, ainda que a escola possua boa estrutura e carga horária, a metodologia da professora influencia na visão que o aluno tem da disciplina. Os 12 alunos que afirmaram não gostar de ter aulas de Espanhol alegaram que não gostam por não se identificarem com a língua e por não se sentirem motivados nas aulas, uma vez que para eles, a professora não realiza muitas atividades "diferentes", apesar de ter tempo e estrutura para tal.

\subsubsection{O que te deixa motivado nas aulas de Espanhol?}

Nas duas turmas analisadas, as razões para a motivação dos alunos foram diversas:

Tabela 9 - Razões para a motivação dos alunos

\begin{tabular}{|c|l|c|l|l|}
\hline \multicolumn{2}{|c|}{ TAGUATINGA } & \multicolumn{3}{c|}{ PARANOÁ } \\
\hline 2 & A professora & 2 & $\begin{array}{l}\text { O esforço e interesse da } \\
\text { professora }\end{array}$ \\
\hline 3 & Conhecimento, aprender & 2 & Conhecimento dos países falantes \\
\hline 3 & Trabalhos artísticos & 2 & Não respondeu & \\
\hline 4 & Pronúncia, sonoridade da língua & 4 & Alcançar uma boa nota & \\
\hline 5 & Conteúdo e exercícios & 5 & Conhecimento, aprender & \\
\hline 8 & Nada & 9 & $\begin{array}{l}\text { Atividades diferentes: filmes, } \\
\text { músicas, dinâmicas }\end{array}$ & \\
\hline & & 11 & Nada \\
\hline
\end{tabular}

Fonte: autoria própria 
Inicialmente, poucos alunos se sentem motivados por suas professoras. Isso pode ser explicado em função de inúmeras razões, tais como falta de vínculo afetivo e de identificação, bem como a criação de estereótipos negativos da figura docente. Alguns alunos são motivados pelo fato de aprender e obter conhecimento, não somente da língua, mas também dos países falantes e de suas culturas, o que também demonstra que esses alunos percebem que este conhecimento pode auxiliá-los em situações futuras, como disse esse aluno de Taguatinga: "pois lá na frente, aquele pouco conhecimento que aprendi irá servir para algo".

Enquanto alguns alunos reclamaram das atividades realizadas em Taguatinga, outros disseram se sentir motivados com os conteúdos e os exercícios realizados, confirmando que o processo de aprendizagem se dá de maneira individual e pode variar, ainda que grande parte se sinta motivada pela realização de atividades diferentes (segundo eles, filmes, músicas, dinâmicas), como alguns alunos do Paranoá.

Outro fator relevante é o fato de alguns alunos de Taguatinga se sentirem motivados pela sonoridade da língua ainda que a escutem pouco, uma vez que as aulas são todas ministradas em Português. Como disseram essas alunas, "ver a professora falando", "o som e o jeito das palavras ditas”, são fatores de grande motivação.

Contudo, é triste notar que o número de alunos desmotivados é significativo nas duas turmas analisadas. Como afirmou Melo (2013, p. 51, grifo meu), “os fatores afetivos como a motivação, a ansiedade e a autoestima facilitam ou atrapalham o processo de ensinoaprendizagem de uma LE". Nos casos dessas duas turmas, a falta de motivação atrapalha a aprendizagem, uma vez que para esses alunos, nenhum motivo foi encontrado como um fator de motivação em suas aulas de Espanhol.

\subsubsection{O que te deixa desmotivado nas aulas de Espanhol?}

Os fatores que deixam os alunos da turma de Taguatinga desmotivados são diversos: o desinteresse dos outros alunos; a professora, a falta de dinâmica, a própria matéria, perder nota, não compreender o conteúdo, falta de aprofundamento. Todavia, o fator mais citado como elemento que desmotiva os alunos de Taguatinga foi o mesmo citado pelos docentes da RA: O pouco tempo de aula, citado por 10 alunos. Logo, a carga horária é o maior fator de desmotivação para os professores e alunos de Taguatinga. Assim, mais uma vez, observando as condições nas quais o Espanhol foi implantado em Taguatinga (e na maioria das cidades 
brasileiras), coincido com o pensamento de Aline Oliveira (2010, p. 55, grifo meu) ao dizer que

\begin{abstract}
Envolver o aluno em uma política linguística abstrata que somente existe em uma publicação documental, é restringi-lo a insignificância, negá-lo o direito a ter acesso a um referencial educativo, é operar de forma demagógica [...], o professor perde o entusiasmo e do aluno é negado o acesso a diversidade linguística e a todas as possibilidades que advém da implantação de uma língua estrangeira obrigatória no currículo escolar.
\end{abstract}

Da mesma maneira, as razões para a desmotivação dos alunos do Paranoá também são diversas: não compreender o conteúdo; tirar notas ruins, falta de recursos, desinteresse dos alunos, falta de prática. Todavia, duas razões foram as mais citadas: a mesmice das aulas e exercícios iguais (estruturais) citadas por 8 alunos, e consequentemente, o método de ensino da professora, citado também por outros 8 alunos. Mais uma vez, as escolhas do professor em sala influenciam no processo de ensino-aprendizagem, pois os alunos não se envolvem na aula e consequentemente podem não aprender, pois não se sentem motivados ou impelidos a participar, contribuindo para a ideia de que atividades com alto grau de motivação geram maior interação dos alunos na LE (NICOLAIDES, 1996).

\title{
4.8.8 Como você gostaria que fossem suas aulas de Espanhol?
}

As respostas das duas turmas foram semelhantes. Grande parte dos alunos de Taguatinga utilizou a palavra "dinâmica" para descrever como gostariam que fossem suas aulas. Esse dinamismo foi explicado por alguns e consistiria em atividades diferenciadas como: gincanas; conversação, estudo da cultura dos países de língua espanhola, aulas mais participativas, com vídeos, músicas e teatro. Alguns alunos disseram que gostariam de ter aulas mais longas para poder aprender de maneira aprofundada, como em cursos pagos.

Já no Paranoá, muitos alunos também disseram que gostariam de ter aulas mais dinâmicas com curiosidades; filmes, cultura, músicas, e menos resolução de exercícios automáticos. Muitos alunos responderam que gostariam que fosse trabalhada a oralidade e conversação em sala por meio de diálogos, ou seja, gostariam de falar em Espanhol nas aulas, como pude constatar nas observações realizadas na turma. De maneira notável, um número considerável de alunos disse que gostaria de ter mais explicação por parte da professora, pois para eles, a professora explica de maneira muito simplificada, como também inferi nas 
observações realizadas nesta turma. Por fim, alguns alunos afirmaram que gostariam de ter mais recursos em sala e mais tempo de aula.

\subsubsection{Você acredita que o tempo para as aulas de Espanhol na sua escola é suficiente para estudar a língua? Por quê?}

Dos 25 alunos que responderam o questionário em Taguatinga, 24 disseram que o tempo que têm de aula ( 1 aula semanal de 50 minutos) não é suficiente para estudar a língua, como é possível ver nos relatos abaixo:

\begin{tabular}{|l|}
\hline 1. "Não, o tempo é muito pouco, não concluímos as atividades em sala". \\
\hline 2. "Não, pois o tempo é curto demais para o aprendizado". \\
\hline 3. "Não, porque não dá tempo nem de responder exercícios". \\
\hline 4. "Não, porque é só uma vez na semana”. \\
\hline 5. "Não, porque 45 minutos não dá pra aprender nada". \\
\hline 6. "Não (...), não dá tempo de aprender, ensinar nem praticar". \\
\hline 7. "Não, pois a professora não consegue passar muito conteúdo". \\
\hline $\begin{array}{l}\text { 8. "Não, pois são apenas } 45 \text { minutos e uma vez na semana, isso é insuficiente para } \\
\text { aprender qualquer língua". }\end{array}$ \\
\hline
\end{tabular}

De fato, tudo o que os alunos afirmaram nos relatos acima foi constatado nas observações realizadas nessa turma:

a. O tempo realmente é curto para um aprendizado efetivo,

b. Não há tempo para explicações complexas e prática da língua,

c. Helena não conseguia transmitir muito conteúdo aos alunos, ao passo que Magali estudou mais de um tempo verbal com sua turma no Paranoá.

d. Alguns alunos não conseguiam terminar as atividades.

Sendo assim, como afirma o último relato citado acima, as observações juntamente com os relatos dos docentes e desses alunos de Taguatinga comprovam que "45 minutos $e$ uma vez na semana, é insuficiente para aprender qualquer língua”.

Na turma do Paranoá houve três opiniões:

a. 10 alunos acreditam que o tempo que têm de estudo da língua (2 aulas semanais de 1h30min) ainda é pouco,

b. 15 acreditam que o tempo é suficiente. Alguns, inclusive, chegam a dizer que sabem que não são todas as escolas que possuem essa carga horária, 
c. Um terceiro grupo (10 alunos) disse que o tempo é suficiente, porém mal aproveitado, o que foi comprovado através de algumas aulas observadas.

\subsubsection{Qual será sua língua de opção no vestibular/PAS/ENEM? Por quais motivos você escolheu esta língua?}

Na tabela abaixo é possível ver as LEs escolhidas pelos alunos nos exames seletivos:

Tabela 10 - Língua estrangeira escolhida no vestibular/PAS/ENEM

\begin{tabular}{|c|c|c|c|}
\hline LÍNGUA & MOTIVO & TAGUATINGA & PARANOÁ \\
\hline Espanhol & $\begin{array}{c}\text { Fácil } \\
\text { compreensão }\end{array}$ & 12 & 28 \\
\hline Inglês & $\begin{array}{c}\text { Já fez ou faz curso } \\
\text { da língua }\end{array}$ & 7 & 2 \\
\hline Inglês & $\begin{array}{c}\text { Identificação e } \\
\text { facilidade }\end{array}$ & 5 & 4 \\
\hline Francês & Já fez curso & 1 & 0 \\
\hline
\end{tabular}

Tanto em Taguatinga como no Paranoá, os alunos que optaram por Espanhol deram a mesma justificativa: a facilidade para compreender a língua. Já os que escolheram Inglês, nas duas turmas dividiram-se em duas categorias: os que se identificavam mais com a língua e os que fizeram ou fazem curso da língua. Somente uma aluna de Taguatinga optará pelo Francês por ser formada na língua, e uma aluna do Paranoá disse que optaria por Inglês e Espanhol, assim, não a incluí na tabela acima.

Cabe salientar que em Taguatinga metade da turma fará as provas em Espanhol e a outra metade em Inglês, ao passo que no Paranoá apenas 6 alunos farão a prova em Inglês. Portanto, por meio desses números é notável que os alunos do Paranoá se sentem mais motivados (e confiantes) para realizar as provas de seleção em língua espanhola, enquanto metade da turma de Taguatinga, ainda que Espanhol seja de melhor compreensão, prefere realizar as provas em língua inglesa.

Com base em todos os dados apresentados (tantos gerais como específicos), após sua análise e discussão, a seguir discorrerei acerca das considerações finais desta pesquisa, a fim de responder às perguntas que nortearam esta investigação, apresentar as contribuições e limitações deste estudo, bem como minhas sugestões para pesquisas futuras. 


\section{CONSIDERAÇÕES FINAIS}

"O fato é que todos aqueles que ainda têm a ousadia de falar e escrever acreditam, ainda que de forma tênue, que o seu falar faz uma diferença."

(RUBEM ALVES, 1980, p. 27)

Nesta última parte, dedico-me às considerações finais deste estudo, que foram divididas em quatro seções: Inicialmente, retomo as perguntas de pesquisa. Em seguida, discorro sobre as contribuições desta investigação e, posteriormente, falo acerca das limitações do estudo bem como de sugestões para pesquisas futuras.

\section{Retomada das perguntas de pesquisa}

Esta investigação teve como objetivos: (1) Descrever como ocorreu e tem ocorrido a implantação da Lei 11.161/2005 em duas RAs do DF: Taguatinga e Paranoá; (2) Analisar se as realidades de ensino com a implantação da Lei 11.161/2005 nestas duas regiões são semelhantes ou se diferem e (3) Apresentar os descompassos presentes nesta implantação, constatando as limitações e necessidades deste ensino. A fim de alcançar os objetivos propostos, empenhei-me em responder a quatro perguntas, as quais serão retomadas a seguir, juntamente com as devidas considerações.

1) De que maneira tem ocorrido o processo de ensino-aprendizagem de Espanhol em escolas públicas do Distrito Federal após a implantação da Lei 11.161/2005?

Como demonstrou esta pesquisa por meio da análise de duas RAs do DF, a inclusão e implantação do Espanhol na grade curricular das escolas públicas do DF deu-se de maneira distinta de RA para RA. No Paranoá, de forma diferente das demais RAs, a implantação do Espanhol ocorreu no ano de 2006, um ano após a sanção da Lei 11.161/2005. Em contrapartida, a maioria das escolas de Taguatinga implantou o Espanhol tardiamente, somente em 2010, prazo final para o cumprimento da legislação. No Paranoá muitas mudanças e melhorias no ensino de Espanhol já foram realizadas, ao passo que a realidade de Taguatinga, de maneira geral, permanece morosa e sem muitas intervenções.

Com base no exposto, atualmente o processo de ensino-aprendizagem de Espanhol em escolas públicas do DF tem caminhado em ritmos diferentes, uma vez que no Paranoá este 
processo tem sido otimizado, visto que as escolas pesquisadas: (1) demonstraram melhor planificação da política linguística em questão; (2) possuem tempo suficiente para as aulas, (3) têm as aulas de Espanhol ministradas na língua, (4) proporcionam aos alunos maior interação com a língua-alvo, (5) ainda que de forma limitada, dispõem de materiais impressos e recursos tecnológicos, (6) têm seu quadro de docentes constituído em sua maioria, por profissionais concursados exclusivamente para língua espanhola.

Em contrapartida, o processo de ensino-aprendizagem de Espanhol nas escolas de Taguatinga ainda apresenta dificuldades inicias da época da implantação, dado que as escolas: (1) em sua maioria, dispõem de tempo limitado (e limitador) para as aulas de Espanhol; (2) não têm as aulas ministradas na língua, (3) proporcionam o ensino da língua de maneira reducionista e superficial, (4) mesmo que não todas, muitas apresentam carência de materiais, (5) têm seu quadro de professores constituído por profissionais concursados para outras disciplinas que não o Espanhol (Português, Atividades e Geografia).

Desse modo, o processo de ensino-aprendizagem de Espanhol em escolas públicas do DF apresenta diferenças, e abarca casos que clamam por intervenções emergenciais (como Taguatinga, lembrando que esta RA constitui o quadro típico da realidade do ensino de Espanhol das demais RAs do DF) e casos que (ainda que possuam necessidades e lacunas) demonstram êxito no ensino de Espanhol quando comparados aos demais, como é o caso do Paranoá.

2) Atualmente, quais as limitações presentes no processo de ensino-aprendizagem de Espanhol em escolas públicas do Distrito Federal?

Independente da RA, muitas limitações e necessidades foram identificadas no ensino de Espanhol das regiões analisadas.

A mais citada tanto por professores como por alunos foi o pouco tempo de aula nas escolas de Taguatinga (50 minutos). Tal carga horária compromete não somente o ensino, mas também a valorização da disciplina, a aprendizagem e o interesse do aluno.

A escassez de recursos, tais como materiais didáticos e aparatos tecnológicos, também se constituiu como uma grande limitação no ensino de Espanhol, visto que muitas escolas não possuem dicionários; livros, gramáticas na língua, e quando possuem, não atendem a todos os alunos. Da mesma forma, outras não têm aparelhos de som em funcionamento, ao passo que em outras, por exemplo, não há folhas para reprodução de exercícios. Logo, há toda espécie de carência de recursos. Tudo isso se torna aspecto limitador no ensino de Espanhol, uma vez 
que em aulas de LE há necessidade de uso de dicionários e gramáticas para desenvolver a leitura; escrita e conhecimento lexical na língua, bem como aparelhos de som para o desenvolvimento de atividades diferenciadas e possibilidade de trabalhar aspectos fonéticos da língua-alvo como acentos e pronúncia.

Todavia, a escassez não abrange somente materiais e aparatos e não se limita apenas ao ensino de Espanhol, como é o caso da estrutura física de determinadas escolas, uma vez que algumas estavam sucateadas, ao ponto de não haver cadeiras suficiente e as salas de aula não propiciarem ambiente adequado para a promoção do processo de ensino-aprendizagem. Aliado a esses fatores, o número de alunos em sala também se configurou um grande limitador, pois não é possível o professor atender a um aluno de maneira individual, juntamente com as dificuldades para se trabalhar a oralidade.

Em Taguatinga o número de alunos influencia, inclusive, as formas de avaliação, visto que um professor de Espanhol atende em média, de 18 a 28 turmas de 45 alunos. Assim, não é possível avaliar os alunos subjetivamente, sendo estes geralmente submetidos a avaliações de múltipla escolha e em duplas. É sabido que o elevado número de alunos é realidade presente em qualquer sala de aula de escola pública independente da disciplina, contudo, torna-se um agravante no ensino de LE por este conter particularidades que devem ser levadas em consideração. Outra limitação presente no ensino de Espanhol é a falta de formação dos docentes da língua, visto que muitos se sentem despreparados para ministrar aulas de Espanhol, e tal despreparo reflete em suas práticas docentes.

Por fim, além das limitações já apresentadas, percebi que ainda falta visão e sensibilidade a muitas escolas, representadas por suas direções e até mesmo, seus docentes. A acomodação, alienação e a falta de ações que visem mudanças e melhorias para o ensino fazem com que o ensino de Espanhol não avance e seja de fato, oferecido com qualidade. Como afirma Leffa (2005, p. 206), “o que fazemos com as palavras é prometer; não é botar a mão na massa e fazer”. Portanto, mesmo que as limitações e necessidades sejam identificadas por muitos, é preciso que haja mobilização e ações efetivas para a mudança.

\section{1) De que forma a carga horária destinada à disciplina influencia no processo de ensino-aprendizagem de Espanhol?}

Uma das maiores diferenças entre as duas RAs analisadas foi a carga horária destinada ao Espanhol: Em Taguatinga, das oito escolas, sete destinam à disciplina a carga horária 
semanal de 50 minutos $^{121}$, enquanto no Paranoá as duas escolas (devido à semestralidade) dedicam ao estudo da língua duas aulas semanais de em média 1 h e 30 minutos cada, totalizando $3 \mathrm{~h}$ por semana.

Notei claramente que a carga horária influencia de inúmeras maneiras, tais como:

a. Motivação do professor. Os professores de Taguatinga apresentaram-se mais desmotivados que os professores do Paranoá, justificando a pouca carga horária como o maior fator para tal desmotivação, dado que lecionam em muitas turmas; às vezes precisam ministrar aulas de outras disciplinas para completar a carga horária e não podem trabalhar a língua da forma como gostariam, caso tivessem tempo suficiente. Assim, tão ínfima carga horária chega a ser desumana com o professor de Taguatinga, que precisa desdobrar-se para realizar seu trabalho.

b. Motivação do aluno. Da mesma maneira, os alunos de Taguatinga também estavam mais desmotivados com o ensino de Espanhol, uma vez que mais da metade da turma analisada afirmou não ser possível aprender Espanhol na escola em função do pouco tempo. De igual forma, enquanto a maioria da turma analisada no Paranoá pretende realizar os exames de seleção (vestibular, ENEM) em Espanhol, ainda que seja uma língua mais próxima ao Português, esse número diminui pela metade em Taguatinga.

c. Qualidade das aulas e da exposição do conteúdo. Como demonstraram os relatos dos professores e alunos, a carga horária influencia diretamente na dinâmica da aula. Enquanto Magali no Paranoá realizava as atividades com calma, dava atendimento individual aos alunos e corrigia os exercícios sem pressa, Helena em Taguatinga parecia sempre tensa com o horário. De igual modo, em Taguatinga não foi possível aprofundar os conteúdos estudados, enquanto no Paranoá os alunos realizaram os exercícios e ainda tiveram aulas de revisão. Cabe destacar que muitos relatos demonstraram que em Taguatinga muitas vezes os alunos não conseguem terminar as atividades em sala, bem como os professores também nem sempre terminam de expor o conteúdo, pois a aula acaba.

d. Interesse do aluno. Os alunos de Taguatinga parecem não valorizar o Espanhol como de fato, uma disciplina, pois muitos não levavam o material para a sala nem realizavam os exercícios, por acreditarem que "não daria tempo". Em contrapartida, ainda que muitos alunos também fossem desinteressados, no Paranoá a turma como

\footnotetext{
${ }^{121}$ A oitava escola (ET8) trabalha em regime de semestralidade, por isso oferece duas aulas de Espanhol durante um semestre letivo.
} 
um todo se dedicava mais à disciplina ao prestar atenção nas explicações e realizar os exercícios propostos.

e. Conteúdo dado. Esse foi um dos fatores que apresentou maior diferença entre as RAs pesquisadas. No início do segundo bimestre a turma de Taguatinga ainda não tinha iniciado o trabalho com os conteúdos do livro de Espanhol, enquanto a turma do Paranoá se aproximava da página 50. No tempo em que observei as duas turmas, Magali trabalhou com seus alunos: Subjuntivo; Pretérito Perfeito do Subjuntivo, Pretérito Pluscuamperfecto, leitura de um conto em Espanhol, Imperativo afirmativo e negativo, resolução de uma prova de Espanhol do vestibular da UnB, comentários de uma prova do ENEM e correção de todos os conteúdos estudados em sala. Em Taguatinga, durante o mesmo período os alunos estudaram: um exercício de vocabulário; o modo Condicional, um exercício de compreensão oral, um exercício avaliativo sobre profissões e as preposições. Dessa forma, a discrepância na quantidade (e aprofundamento) de conteúdo estudado entre as duas turmas é notável.

f. Contato do aluno com a língua. Enquanto as aulas no Paranoá são ministradas em Espanhol, as aulas em Taguatinga, além de curtas, são todas ministradas em Português. De igual modo, os alunos do Paranoá se mostraram mais motivados em praticar a oralidade, ainda que essa prática não fosse exigida pela professora.

g. Conhecimento e preparação do aluno. Pelas atividades realizadas e conteúdos abarcados, constatei que a turma do Paranoá possui mais conhecimentos em Espanhol e é mais bem preparada para o vestibular, visto que tem oportunidade de: resolver provas de vestibular em sala com o auxílio do professor; trabalhar aspectos gramaticais com tranquilidade, realizar leituras na língua, ter aulas de revisão dos conteúdos estudados. Enquanto isso, em Taguatinga os alunos estudaram aspectos básicos da língua de maneira superficial, sem a oportunidade de aprofundamento nos exercícios e conteúdos ministrados.

h. Relação professor-aluno. Inferi que a carga horária também influencia na relação interpessoal entre professor e aluno. Magali no Paranoá tinha 6 turmas e as conhecia muito bem: chamava seus alunos pelo nome e os atendia de maneira individualizada, além de encontrá-los duas vezes por semana. De maneira contrária, Helena em Taguatinga tinha 28 turmas. Logo, Helena tinha dificuldades em conhecer todos os seus alunos, uma vez que eram muitos e os encontrava rapidamente, uma vez por semana. 
i. Atividades realizadas em sala. A carga horária também influencia nas atividades que o professor realiza em sala. Magali no Paranoá (ainda que tentasse dar maior destaque a aulas expositivas com foco gramatical) tinha tempo suficiente para projetar um filme completo em uma aula; trabalhar com músicas, realizar leituras, dinâmicas, e até mesmo, avaliar a oralidade de seus alunos (ainda que não o fizesse). Helena, em seu pouco tempo, conseguia fazer o tempo render, porém apenas com exercícios mecânicos, sem atividades diferenciadas. Provavelmente seja possível um professor realizar atividades diferenciadas em uma aula de 50 minutos, contudo, certamente o aproveitamento dessas atividades seria maior caso houvesse mais tempo.

Com base no exposto, se percebe que o planejamento do conteúdo no tempo é imprescindível para uma boa aula, e que a carga horária influencia de diversas formas no processo de ensino-aprendizagem de Espanhol, sendo válido salientar que essas formas não se esgotam nas constatações acima.

\section{3) Que medidas podem ser tomadas para melhorar o processo de ensino-aprendizagem de Espanhol em escolas públicas do Distrito Federal?}

Analisando as realidades apresentadas e considerando medidas práticas para a melhoria do ensino de Espanhol no DF, sugiro:

a. Aumento da carga horária destinada à disciplina. Considerando o exemplo das escolas do Paranoá (que redistribuíram horários de PD e Ensino Religioso), sugiro que cada escola avalie as condições existentes para aumentar a carga horária de Espanhol. Tal medida contribuirá para um ensino de maior qualidade e diminuição da carga do professor.

b. Atender ao dispositivo das leis no tocante ao ensino de Espanhol no Fundamental. A Lei federal 11.161/2005 bem como a lei distrital $n^{\circ} 3.694$ aconselham o ensino de Espanhol no Ensino Fundamental, entretanto, as escolas não cumprem esse dispositivo. A inclusão do Espanhol no Ensino Fundamental proporcionaria ao aluno maior conhecimento da língua, bem como uma maior "bagagem" ao entrar no Ensino Médio. Tal medida não consiste em apenas uma sugestão, mas em uma obrigação e cumprimento das legislações educacionais vigentes ${ }^{122}$.

\footnotetext{
${ }^{122}$ Ainda que a inclusão do Espanhol no Ensino Fundamental não seja realidade no DF e em diversos estados brasileiros, muito me alegrei ao participar do II EFORPE (Encontro de Formação de Professores de Espanhol) e do I SIELE (Simpósio Internacional de Ensino de Língua Espanhola) em Florianópolis, no mês de novembro de
} 
c. Realização de Projetos de LEM. Realização de projetos culturais nas escolas que trabalhem a cultura dos países falantes das línguas estudadas pelos alunos.

d. Parceria com Embaixadas. Seguindo o exemplo da escola EP1, buscar adoção e parceria com Embaixadas, a fim de proporcionar aos alunos maior conhecimento e contato não somente com as línguas, mas também com a cultura dos países.

e. Criação da "Sala de Línguas". Uma vez que as aulas de LE necessitem de materiais diversos tais como dicionários; livros didáticos, gramáticas, aparelhos de som, televisão, datashow, etc, sugiro que cada escola tenha uma "Sala de línguas", que consistiria em uma sala de aula dotada dos materiais acima, disponíveis nas línguas estudadas e decorada de forma que o aluno se sinta envolvido no estudo das línguas e de suas culturas.

f. Divisão das turmas para aulas de LEM. A fim de otimizar o ensino de LEM na escola regular, sugiro que para aulas de LEM a turma seja dividida. Por exemplo: metade dos alunos assistiria à aula de Espanhol, e a outra metade, à aula de Inglês (caso esta seja a $2^{a}$ língua oferecida pela escola). Na próxima aula, o aluno que assistiu à aula de Espanhol assistiria a de Inglês, e vice-versa ${ }^{123}$.

Além das medidas sugeridas acima, há medidas que devem ser tomadas por instâncias governamentais como o aumento de recursos para compra de material e aparelhos; maiores oportunidades de cursos de formação para professores da rede pública oferecidos pelas Secretarias e pelas Instituições devidas (com preços acessíveis e liberação das escolas), bem como a convocação de professores de Espanhol aprovados em concurso público. Com base nas considerações feitas, coincido com Maciel e Oliveira (2011, p. 3) quando afirmaram que "para que a lei realmente entre em vigor muitas serão as mudanças dentro do ambiente escolar: estrutura física, grade curricular, formação de docentes, entre outros".

Por fim, constatei ao longo da pesquisa que para que reais mudanças ocorram, não basta tão somente identificar os aspecto fragilizados e esperar que os órgãos competentes tomem providências para a melhoria do ensino. É necessário que haja uma vontade coletiva (BOHN, 2000), uma homogeneidade de pensamento da comunidade escolar (direção, professores, pais e alunos). De igual modo, é necessário que o professor tenha consciência

2014, pois, nesses eventos, pude ter conhecimento de oito escolas municipais em Santa Catarina que já incluíram o Espanhol em turmas de $1^{\text {a }}$ a $5^{\text {a }}$ série. Tal inserção serve de motivação para as demais escolas de Ensino Fundamental, bem como para os demais estados do Brasil.

${ }^{123}$ Já trabalhei em uma escola particular que realizou esta divisão, logo, ainda que demande modificações estruturais, de carga horária, espaço físico e inclusive, de diários de classe diferenciados, na prática tal medida é possível desde que as línguas estudadas possuam a mesma carga horária. Além de criar melhores condições para o professor e o aluno, as aulas poderiam contemplar atividades diferenciadas e mais enriquecedoras. 
política e se veja como um agente político (LEFFA, 2005) capaz de produzir intervenções na prática social, como afirma Bohn (op. cit., p. 129, grifo meu) ao dizer que

\footnotetext{
As próprias pesquisas e os documentos do MEC atestam que as políticas educacionais mais bem sucedidas são aquelas que passaram por uma ampla discussão com a participação da comunidade interessada. No processo decisório é essencial o comprometimento do profissional na implementação de políticas educacionais.
}

Portanto, concluo que para que o processo de ensino-aprendizagem de Espanhol em escolas públicas do DF obtenha êxito e logre melhorias, é essencial e totalmente necessário que haja real conscientização e mobilização conjunta.

\section{Contribuições da investigação}

Esta pesquisa, situada em um âmbito crítico, interventor e reflexivo, ao analisar um evento contemporâneo dando voz a professores e alunos, fez uso da LA em sua vertente crítica ao apontar as falhas e os êxitos do ensino de Espanhol no DF, bem como os descompassos de uma legislação educacional vigente prestes a completar uma década de existência no Brasil, porém pouco pesquisada e avaliada. Assim, acredito que este trabalho pôde trazer contribuições em diferentes níveis.

Inicialmente, à área da Linguística Aplicada por dedicar-se ao estudo e análise de uma política (pública, educacional e linguística), contribuindo para o crescimento desse campo de investigação considerado recente no Brasil. É visível a ascendência do interesse pelas políticas públicas, educacionais e linguísticas, uma vez que nos dias atuais é cada vez mais latente o foco "no processo de invenção e fabricação que nos chama para a responsabilidade de mudanças e futuros sociais possíveis!” (FABRÍCIO, 2006, p. 58). Portanto, buscando produzir conhecimentos que tragam ganhos e melhorias para a qualidade de vida (ROJO, 2013), esta investigação contribuiu com a exposição de uma visão real da implementação da Lei 11.161/2005, uma vez que apresentou realidades distintas da implantação desta lei e suas repercussões na vivência escolar real ao dar voz a professores e alunos.

É preciso lembrar que "a menudo los discursos están bien lejos de la realidade del estudiante" (VIÑAL JÚNIOR, 2012b, p. 9). Logo, compreender como este ensino tem ocorrido fazendo relação entre a teoria e a prática, a lei e sua aplicação, são fundamentais para que seja possível propor mudanças efetivas e reais no ensino de Espanhol. Desse modo, os 
dados aqui apresentados representam uma contribuição para intervenções nos órgãos e instituições responsáveis pela implantação dessa língua.

Este estudo também contribuiu para o ensino de Espanhol no Brasil, pois gerou conhecimento de como a Lei 11.161/2005 foi de fato implantada no Distrito Federal, que abriga a capital da República. Cabe o destaque de que esta lei é recente, e sobre sua aplicação e realidade atual ainda há escassez de trabalhos e estudos comparativos que apresentem uma visão real. Logo, esta pesquisa integra-se aos poucos trabalhos já realizados sobre a realidade por trás da implantação da Lei 11.161/2005.

Com a exposição das escolas do Paranoá e o contraste realizado com as escolas de Taguatinga, este estudo contribuiu para que fosse possível perceber que ainda há maneiras de oferecer com qualidade o ensino de LEM em escolas públicas regulares, necessitando tão somente da mobilização conjunta para que melhorias sejam realizadas.

Esta investigação também trouxe contribuições à "Formação de Professores", visto que apresentou relatos reais de docentes e práticas efetivas que demonstraram quão grande é a carência, bem como a necessidade de que sejam oferecidos cursos de formação continuada aos professores, que por vezes, sentem-se incapacitados para lecionar aulas de Espanhol com qualidade e segurança.

Por fim, esta investigação tenta mostrar que é preciso um olhar mais crítico dos órgãos competentes, ao de fato perceber que o aluno da escola pública não deve ser privado de um ensino efetivo de Espanhol, pois aqui foram expostas as falhas, as necessidades e as privações deste ensino. Manter a realidade atual é "como se excluíssemos o já excluído" (VIÑAL JÚNIOR, 2012a, p. 15). Portanto, apresentar a visão real dessa implantação apontando suas falhas e êxitos é preparar o palco para que, de fato, as melhorias comecem a acontecer.

\section{Limitações do estudo e sugestões para pesquisas futuras}

Desenvolver uma investigação não é tarefa fácil. Além do grande empenho e dedicação que a pesquisa demanda, é necessário que o pesquisador saiba lidar com os percalços que surgem no meio do caminho, como exporei a seguir.

Maciel e Oliveira (2011, p. 13) compartilharam de uma dificuldade que encontrei ao realizar esta investigação, ao afirmarem que "por tratar-se de uma pesquisa com problemática recente, sente-se a carência de referencial teórico específico". Logo, tive dificuldades em encontrar bibliografia sólida e dados sobre as realidades da implantação e, assim como as 
autoras, busquei leituras diárias de páginas eletrônicas referentes ao assunto e novas informações "a partir de contatos estabelecidos entre professores, estabelecimentos de ensino e Núcleo de educação" (IBIDEM). Dessa forma, foi necessário um tempo considerável para o levantamento bibliográfico, no qual encontrei excelentes trabalhos que muito me auxiliaram. Ainda nesse sentido, outra limitação foi a dificuldade para ter acesso a documentos e legislações específicas e antigas. Algumas (ainda que poucas), de fato, por mais que eu tenha buscado em todas as fontes disponíveis ao meu alcance, não consegui encontrar.

Em relação à coleta de dados, lidar e depender de pessoas também se configura uma tarefa complexa. Não obtive resposta de alguns professores, e assim, concordo com Amaral e Mazzaro (2007, p. 4) quando disseram que: "Talvez esse fato possa ser interpretado como uma falta de interesse de diálogo sobre as necessidades de mudança no ensino de língua estrangeira, especialmente no ensino de espanhol...”. Porém não foi somente essa questão, infelizmente pela distância e minha impossibilidade de visitar as escolas no turno noturno não consegui encontrar todos os professores deste turno. As poucas aulas em Taguatinga e as interrupções e intervenções ocorridas entre uma aula e outra também foram elemento limitador, uma vez que depois de terminado o período de coleta de dados no Paranoá necessitei estendê-lo em Taguatinga após o recesso escolar, decidindo com minha orientadora não observar o mesmo número de aulas que observei no Paranoá, pois, a observação de mais três aulas em Taguatinga demandaria quase um mês a mais, por ser uma aula semanal.

Por fim, dada a carência de estudos nessa área recente em solo brasileiro, sugiro que sejam realizadas mais investigações sobre as realidades do processo de ensino-aprendizagem de Espanhol após a sanção da lei em 2005 e sua obrigatoriedade em 2010, uma vez que a obrigatoriedade do ensino de Espanhol no Brasil está prestes a completar 10 anos, tornando necessário fazer um balanço e uma avaliação dos pontos positivos e negativos.

Da mesma forma, sugiro investigações com foco não somente em realidades difíceis, mas também em realidades exitosas que possam servir de exemplo, estímulo e inspiração para as demais. Proponho também que se investiguem as diferentes medidas que os Estados e Secretarias tomaram e têm tomado em relação à implantação do Espanhol, no intuito de identificar as diferentes ações ao redor do Brasil. Acredito que quanto mais evidentes forem as realidades do ensino de Espanhol em escolas públicas espalhadas pelo território nacional, maior será a conscientização de que há mudanças que devem ser realizadas e necessidades que devem ser supridas, para que o aluno enfim, possa desfrutar de um ensino realizado com primor, excelência e dignas condições. 


\section{REFERÊNCIAS}

ALMEIDA FILHO, J. C. P. de. Maneiras de compreender Linguística Aplicada. Revista Letras, n. 2, Santa Maria: Universidade Federal de Santa Maria, p. 7-14, 1991.

ALMEIDA FILHO, J. C. P.; REIS, S; MICCOLI, L. (Equipe de redação). Carta de Londrina. Londrina, 2014. Disponível em:

< http://www.uel.br/eventos/forumdocente/>. Acesso em: 10 nov. 2014.

ALVES, R. Conversas com quem gosta de ensinar. São Paulo: Cortez/Autores associados, 1980.

AMARAL, E. R. T; ALMEIDA, E. G. de. Qual é o lugar do espanhol nas escolas de ensino médio de Minas Gerais? In: CIPLOM, 1, 2010, Foz do Iguaçu. Anais... 2010, pp. 313-322.

AMARAL, E. R. T; MAZZARO, D. Repercussões da Lei $\mathbf{n}^{0}$ 11.161/2005: reflexões sobre o ensino de espanhol no Brasil. Língua e Literatura Journal, vol 2, $\mathrm{n}^{\circ}$ 2, 2007. Disponível em: $\langle$ http://ojs.gc.cuny.edu/index.php/lljournal/article/viewArticle/239/256>. Acesso em: 04 abr. 2013.

ANDRADE, A. A. C. Crenças de alunos e professores da escola pública sobre a aprendizagem de língua na escola regular. Dissertação (Mestrado em Estudos da Linguagem). UFRN, Natal, 2004.

ANDRÉ, M. E. D. A. Estudo de caso em pesquisa e avaliação educacional. Brasília: Líber Livro Editora, 2005.

1984.

Estudo de caso: seu potencial na educação. Cadernos de Pesquisa, nº 49, maio,

ARIAS, J. Escolas do Brasil vão ter espanhol obrigatório. In: El País. Publicado no site da Associação Brasileira de Editores de Livros. Disponível em: 〈www.abrelivros.org.br>. Acesso em: 01 set. 2013.

AUGUSTO, M. H. O. Políticas públicas, políticas sociais e política de saúde: algumas questões para reflexão e debate. Tempo Social; Ver. Sociol. USP, S. Paulo, 1(2): 105-119, 2. sem, 1989.

BAPTISTA, L. M. T. R. TECNOLOGIAS, MULTILETRAMENTOS E ENSINO DE ESPANHOL. In: DIREITOS À APRENDIZAGEM DA LÍNGUA ESPANHOLA NA EDUCAÇÃO BÁSICA. Ano XXIV, Boletim 2, mai. 2014, pp. 24-30.

BOBBIO, N. et al. Dicionário de política. Tradução: Carmen Varriale et al. v.2, 4. ed. Editora UNB. São Paulo, 2000.

BOHN, H. I. As exigências da pós-modernidade sobre a pesquisa em Linguística Aplicada no Brasil. In: FREIRE, M. M.; ABRAHÃO, M. H. V.; BARCELOS, A. M. F. (Org.). 
Linguística Aplicada e Contemporaneidade. São Paulo, SP: ALAB; Campinas, SP: Pontes Editores, 2005. pp. 11-23.

Os aspectos 'políticos' de uma política de ensino de línguas e literaturas estrangeiras. Linguagem \& Ensino, Universidade Católica de Pelotas. Pelotas, RS, Vol. 3, No. 1, p. 117-138, 2000.

BORTONI-RICARDO, S. M. O professor pesquisador: introdução à pesquisa qualitativa. 2 . ed. São Paulo: Parábola Editorial, 2009.

BRUMFIT, C. Teacher Professionalism and Research. In: COOK, G; SEIDLHOFER, B. (eds). Principle and Pratice in Applied Linguistics: Studies in honor of H. G. Widdowson. Oxford: OUP, 1995. pp. 27-41.

CALVET, L-J. As políticas linguísticas. Florianópolis e São Paulo: IPOL/Parábola, 2007.

CAMARGO, M. L. de. O ENSINO DO ESPANHOL NO BRASIL: UM POUCO DE SUA HISTÓRIA. Trab. Ling. Aplic., Campinas (43): pp. 139-149, jan/jun. 2004.

CELADA, M. T. O espanhol para o brasileiro: uma língua singularmente estrangeira. 2002. 277 f. Tese (doutorado) - Universidade Estadual de Campinas, Instituto de Estudos da Linguagem, Campinas, SP, 2002.

CELADA, M. T; RODRIGUES, F. S. C. El español en Brasil: actualidad y memoria. Real Instituto Elcano, 2005, pp. 1-10.

CELANI, M. A. A. A relevância da Linguística Aplicada na Formulação de uma Política Educacional Brasileira. In: FORTKAMP, M. B. F.; TOMITCH, L. M. B. (Org.). Aspectos da Linguística Aplicada. Estudos em homenagem ao professor Hilário Inácio Bohn. 2. ed. Florianópolis: Insular, 2008. pp. 17-32.

CELLARD, A. A análise documental. In: POUPART, J. et al. A pesquisa qualitativa: enfoques epistemológicos e metodológicos. Petrópolis, Vozes, 2008, pp. 295-315.

CHAGAS, V. Didática especial de línguas moderna. 3. ed. São Paulo, Nacional, 1979.

CHIZZOTTI, A. Pesquisa qualitativa em ciências humanas e sociais. 4. ed. Petrópolis, RJ: Vozes, 2011.

CODEPLAN. Companhia de Desenvolvimento do Planalto Central. Pesquisa Distrital por Amostragem de Domicílios - Paranoá. PDAD/2013, 2013a.

Companhia de Desenvolvimento do Planalto Central. Pesquisa Distrital por Amostragem de Domicílios - Taguatinga. PDAD/2013, 2013b.

COELHO, H. S. H. "É possível aprender inglês em escolas públicas?" Crenças de professores e alunos sobre o ensino de inglês em escolas públicas. Dissertação (Mestrado em Estudos linguísticos). UFMG, Belo Horizonte, 2005. 
COSTA, E. G. M.; RODRIGUES, F. C.; FREITAS, M. A. de. IMPLANTAÇÃO DO ESPANHOL NA ESCOLA BRASILEIRA: POLÊMICA E DESAFIOS. Disponível em: 〈www.letras.ufscar.br/linguasagem/edicao10/espanholnaescbr.php >. Acesso em: 04 abr. 2013.

CRISTOFOLI, M. S. POLÍTICAS PARA A EDUCAÇÃO BÁSICA E AS LÍNGUAS ESTRANGEIRAS NOS DOCUMENTOS OFICIAIS DO BRASIL, ARGENTINA E MERCOSUL EDUCACIONAL. In: ANPED, IX, 2012, pp 1-15.

DALINGHAUS, I. V. Uma Reflexão Imprescindível e Inadiável Sobre Políticas Linguísticas em Contextos Fronteiriços. Web revista de debates: questões de linguística e linguagem. $\quad$ v. $6 . \quad$ jun. 2009. Disponível em: $<$ http://www.linguisticaelinguagem.cepad.net.br/EDICOES/06/06.htm $>$. Acesso em: 15 jul. 2014.

DE GRANDE, P. B. O pesquisador interpretativo e a postura ética em pesquisas em Linguística Aplicada. Eletras, v. 23, n.23, p. 11-27, dez. 2011.

DENZIN, N. K. The Research Act. (3rdedn). Englewood Cliffs, NJ: Prentice Hall, 1989.

; LINCOLN, Y. S. Introdução. A disciplina e a prática da pesquisa qualitativa. In: DENZIN, N. K; LINCOLN, Y. S. (Orgs.) O planejamento da pesquisa qualitativa: Teorias e abordagens. Porto Alegre: Artmed, 2006, pp. 15 -41.

DESLAURIERS, J. P; KÉRISIT, M. O delineamento da pesquisa qualitativa. In: POUPART, J. et al. A pesquisa qualitativa: enfoques epistemológicos e metodológicos. Petrópolis, Vozes, 2008, pp. 127-153.

DIAS, M. M. L. INTRODUÇÃO. A LÍNGUA ESPANHOLA NA EDUCAÇÃO BÁSICA BRASILEIRA. In: DIREITOS À APRENDIZAGEM DA LÍNGUA ESPẢNHOLA NA EDUCAÇÃO BÁSICA. Ano XXIV, Boletim 2, mai. 2014, pp. 4-9.

DISTRITO FEDERAL. Censo escolar 2014 (Rede Pública). Disponível em: <http://www.cre.se.df.gov.br/ascom/documentos/censo/2014/turmas_matr\%C3\%ADculas_20 14.pdf>. Acesso em: 15 ago. 2014.

Secretaria de Educação. Orientações Curriculares, 2009.

ERICKSON, F. Qualitative Methods in Research on Teaching. In: WITTROCK.M.C. (Ed.). Handbook of research on teaching. New York: Macmillian, pp. 119-161, 1986.

FABRÍCIO, B. F. Linguística Aplicada como espaço de desaprendizagem: redescrições em curso. In: MOITA-LOPES, L. P. (Org.). Por uma Linguística Aplicada Indisciplinar. São Paulo: Parábola Editorial, 2006. pp. 45-63.

FÉLIX, A. Crenças do professor sobre o melhor aprender de uma língua estrangeira na escola. Dissertação (Mestrado em Linguística Aplicada). UNICAMP, Campinas, 1998.

FERNÁNDEZ, G. E. Entre enfoques e métodos: algunas relaciones (in)coerentes en la enseñanza de español lengua extranjera. In: BARROS, C. S.; COSTA, E. G. M. (Org.). 
Espanhol Ensino médio. Coleção Explorando o Ensino. Brasília: Ministério da Educação, Secretaria de Educação Básica, 2010, pp. 69-84.

ALGUMAS RAZÕES PARA ENSINAR E APRENDER ESPANHOL NA ESCOLA. In: DIREITOS À APRENDIZAGEM DA LÍNGUA ESPANHOLA NA EDUCAÇÃO BÁSICA. Ano XXIV, Boletim 2, mai. 2014, pp. 17-23.

FLICK, U. Introdução à pesquisa qualitativa. Tradução Joice Elias Costa. 3. ed. Porto Alegre: Artemed, 2009a.

Qualidade na pesquisa qualitativa. Tradução Roberto Cataldo Costa. Porto Alegre: Artmed, 2009b.

FOCAULT, M. The Archaeology of Knowledge. London: Routledge, 1989.

FONTANA, M. J; FÁVERO, A. A. PROFESSOR REFLEXIVO: UMA INTEGRAÇÃO ENTRE TEORIA E PRÁTICA. In: REI - Revista de Educação do IDEAU. Vol. 8, nº 17 , jan-jun, 2013, pp. 1-15.

FRANCISCO, M. Resenha. Alfa, São Paulo, 53 (1), p. 303-311, 2009.

GIL, A. C. Como elaborar projetos de pesquisa. 5. ed. São Paulo: Atlas, 2010.

GIMENEZ, T. A ausência de políticas para o ensino da língua inglesa nos anos iniciais de escolarização no Brasil. In: NICOLAIDES, C. S.; ROCHA, C. H.; SILVA K. A.; TÍLIO, R. C. (Orgs.). Política e Políticas Linguísticas. Campinas, SP: Pontes Editores, 2013, pp. 199218.

GONZÁLEZ, N. M. A lei 11.161, as Orientações Curriculares e as políticas públicas de formação de professores: a história de um descompasso entre o dizer e o fazer. Disponível em: 〈www.letras.ufmg.br/espanhol/anais_paginas_\%203079-3467/A\%20lei\%2011.161.pdf> Acesso em: 02. Ago. 2014.

Iniciativas para a implantação do espanhol: a distância entre o discurso e a prática. In: BARROS, C. S.; COSTA, E. G. M. (Org.) Espanhol Ensino médio. Coleção Explorando o Ensino. Brasília: Ministério da Educação, Secretaria de Educação Básica, 2010, pp. 25-54.

A importância da formação inicial e continuada na atual conjuntura da implantação do ensino de espanhol nas escolas brasileiras. In: BARROS, C. S.; COSTA, E. G. M. (Orgs.) Se hace caminho al andar: reflexões em torno do ensino de espanhol na escola. Belo Horizonte: Faculdade de Letras da UFMG, 2012, pp. 15-22.

GRIN, F. O ensino das línguas estrangeiras como política pública. Relatório encomendado pelo HAUT CONSEIL DE L'EVALUATION DE L'ECOLE. Paris, nº 19, set, 2005.

GROULX, L. H. Contribuição da pesquisa qualitativa à pesquisa social. In: POUPART, J. et al. A pesquisa qualitativa: enfoques epistemológicos e metodológicos. Petrópolis, Vozes, 2008, pp. 95-124. 
GUIMARÃES, A. História do ensino de espanhol no Brasil. Scientia Plena, Sergipe, v. 7, n. 11, 2011.

\section{A LÍNGUA ESPANHOLA COMO DISCIPLINA ESCOLAR:}

CONSIDERAÇÕES INICIAIS DE PESQUISA. In: Colóquio Internacional "Educação e Contemporaneidade", 6, 2012, Sergipe. Anais... Sergipe, 2012.

HÖFLING, E. M. Estado e políticas (públicas) sociais. Caderno CEDES [online], v. XXI, n. 55, pp. 30-41, nov. 2011.

HOOKS, B. Eros, erotismo e processo pedagógico. In: LOURO, G. L. (Org.). O corpo educado: pedagogias da sexualidade. Trad. de Tomaz Tadeu da Silva. 2. ed. Belo Horizonte: Autêntica, 2000.

JAEGER, D. Língua Espanhola nas escolas brasileiras, integração e política linguística: reflexões em torno da aprovação da Lei 11.161/05. Espaço Acadêmico, no 97, pp. 31-36, jun. 2009.

JANTUTA, L. POLÍTICA LINGUÍSTICA E ENSINO DE LÍNGUAS NO SCMB: ENUNCIADOS SOBRE A IMPLANTAÇÃO DO ESPANHOL ANTERIOR À LEI 11.161/05. Dissertação (Mestrado em Estudos Linguísticos). UFSM, Santa Maria, 2010.

KLEIMAN, A. B. O estatuto disciplinar da Linguística Aplicada: o traçado de um percurso, um rumo para o debate. In: SGNORINI, I.; CAVALCANTI, M. (Org.). Linguística Aplicada e Transdiciplinaridade. Campinas: Mercado das Letras, 1998. pp.47-70.

KULIKOWSKI, M. Z. M. La lengua española em Brasil: um futuro promisor. In: SEDYCIAS, João (Org.). O ensino de espanhol no Brasil: passado, presente e futuro. São Paulo: Parábola Editorial, 2005.

LASECA, A. M. C. O ensino do espanhol no sistema educativo brasileiro. Brasília: Thesaurus, 2008.

LE BRETON, J. M. Reflexões anglóficas sobre a geopolítica do inglês. In: LACOSTE, Y; RAJAGOPALAN, K. (Org.). A geopolítica do inglês. São Paulo: Parábola, 2005.

LEFFA, V. J. O professor de línguas estrangeiras: do corpo mole ao corpo dócil. In: FREIRE, M. M.; ABRAHÃO, M. H. V.; BARCELOS, A. M. F. (Org.). Linguística Aplicada e Contemporaneidade. São Paulo, SP: ALAB; Campinas, SP: Pontes Editores, 2005. pp. 203218.

Prefácio. In: NICOLAIDES, C. S.; ROCHA, C. H.; SILVA K. A.; TÍLIO, R. C. (Orgs.). Política e Políticas Linguísticas. Campinas, SP: Pontes Editores, 2013, pp. 7-11.

LEMOS, M. A. O Espanhol em redes de memória. Antigas rotinas e novos sentidos dessa língua no Brasil. 2008. 128 f. (Dissertação - Programa de Pós-graduação em Língua Espanhola e Literaturas Espanhola e Hispano-Americana) - Faculdade de Filosofia, Letras e Ciências Humanas da Universidade de São Paulo, 2008. 
LIMA, L. M; ORTÍZ ALVAREZ, M. L. O ensino das expressões idiomáticas em língua espanhola e suas equivalências em língua portuguesa. Horizontes de Linguística Aplicada, ano 10, n. 1, jan/jun. 2011.

LIMA, V. G. Política Pública: discussão de conceitos. Interface, Porto Nacional, ed. 5, pp. 49-54, out. 2012.

LIRA, Á. (2005). Espanhol no ensino brasileiro. Lei no 11.161 de 2005. Série Separata de leis, decretos, etc. $\mathrm{n}^{\circ}$ 60. Brasília: Câmara dos Deputados/Departamento de Apoio Parlamentar, reimpressão 2007.

LUDKE, M. \& ANDRÉ, M. E. D. A. Pesquisa em Educação: abordagens qualitativas. 2. ed. Rio de Janeiro: E.P.U, 2013.

MACIEL, D. T. E; OLIVEIRA, R. C. S. A IMPLANTAÇÃO DA LÍNGUA ESPANHOLA NO ENSINO MÉDIO PÚBLICO: CONQUISTAS E DESAFIOS. In: Seminário de Pesquisa do PPE, 2011, Maringá. Anais... Maringá, 2011, pp. 1-16.

MACIEL, D. T. E. A implantação da língua espanhola no ensino médio público do município de Ponta Grossa - conquistas e desafios. 2011, 143f. Dissertação (Mestrado em Educação) - Universidade Estadual de Ponta Grossa, Ponta Grossa, 2011.

A LÍNGUA ESPANHOLA NO CURRÍCULO DAS ESCOLAS PÚBLICAS.

In: ENDIPE, XVI, 2012, Campinas. Anais... Campinas, 2012, pp. 2-12.

MAHER, T. M. Ecos de resistência: Políticas linguísticas e línguas minoritárias no Brasil. In: NICOLAIDES, C. S.; ROCHA, C. H.; SILVA K. A.; TÍlIO, R. C. (Orgs.). Política e Políticas Linguísticas. Campinas, SP: Pontes Editores, 2013, pp.117-134.

MARCONI, M. A; LAKATOS, E. M. Técnicas de pesquisa. 7. ed. São Paulo: Atlas, 2009.

MARTINS, H. H. T. S. Metodologia qualitativa de pesquisa. Educação e Pesquisa, São Paulo, v.30, n.2, pp. 289-300, maio/ago. 2004.

MAY, T. Pesquisa social: questões, métodos e processos. Tradução Carlos Alberto Silveira Netto Soares. 3. ed. Porto Alegre: Artemed, 2004.

MEC/SEB. Orientações curriculares para o ensino médio. Linguagens, códigos e suas tecnologias. Conhecimentos de Línguas Estrangeiras; Conhecimentos de Espanhol. Brasília: MEC, Secretaria de Educação Básica, 2006, p. 85-124; p. 127-164.

Parâmetros curriculares nacionais: Ensino Médio. Brasília: MEC, Secretaria de Educação $\quad$ Básica, 2000. Disponível em: 〈http://portal.mec.gov.br/seb/arquivos/pdf/14_24.pdf>. Acesso em: 22 fev. 2013.

Parâmetros Curriculares nacionais: terceiro e quarto ciclos do ensino fundamental: língua estrangeira. Brasília: MEC, Secretaria de Ensino Fundamental, 1998. 
MELO, F. A. O uso do lúdico como atividade significativa no ensino-aprendizagem do espanhol como LE no ciclo juvenil. Brasília: Departamento de Línguas Estrangeiras e Tradução, Universidade de Brasília, 2013, 172f. Dissertação de mestrado.

MENEZES, V.; SILVA, M. M.; GOMES, I. F. Sessenta anos de Linguística Aplicada: de onde viemos e para onde vamos. In: SGNORINI, I.; CAVALCANTI, M. (Org.). Linguística Aplicada e Transdiciplinaridade. Campinas: Mercado das Letras, 1998. pp. 25-50.

MESQUITA, P. P. P. (Re) Construindo Políticas Públicas Para os Centros Interescolares de Línguas do Distrito Federal. 2014. 234f. Dissertação (Mestrado em Linguística Aplicada) - Instituto de Letras, Departamento de Línguas Estrangeiras e Tradução, Universidade de Brasília, 2014.

MIRANDA, M. M. F. Crenças sobre o ensino-aprendizagem de língua estrangeira (inglês) no discurso de professores e alunos de escolas públicas. Dissertação (Mestrado em Linguística Aplicada). Universidade Estadual do Ceará, Fortaleza, 2005.

MOITA LOPES, L. P. da. Alguns comentários sobre o documento "Proposta de linhas gerais para Nortear uma Política de Ensino de Língua Estrangeira Moderna na Rede Oficial de $1^{\circ}$ grau" elaborado pela Com. De Avaliação e Reformulação do Ensino de Língua Estrangeira Moderna do Est. SP. Trabalhos em Linguística Aplicada, nº 10, 1986, pp. 99-102.

Pesquisa interpretativista em Linguística Aplicada: a linguagem como condição e solução. DELTA, v.10, n.2, p. 329-338, 1994.

(Org.). Por uma linguística aplicada indisciplinar. São Paulo: Parábola, 2006.

Uma Linguística Aplicada mestiça e ideológica: Interrogando a campo como linguista aplicado. In: MOITA LOPES, L.P. (Org.). Por uma Linguística Aplicada Indisciplinar. São Paulo: Parábola, 2006a. pp. 13-42.

Linguística Aplicada e vida contemporânea: problematização dos construtos que têm orientado a pesquisa. In: MOITA LOPES, L.P. (Org.). Por uma Linguística Aplicada Indisciplinar. São Paulo: Parábola, 2006b. pp. 85-105.

Da aplicação de Linguística à Linguística Aplicada Indisciplinar. In: PEREIRA, R. C.; ROCA. P. (Org.). Linguística aplicada um caminho com diferentes acessos. 1. ed. São Paulo: Contexto, 2011. pp. 11-23.

MORENO FERNÁNDEZ, F. El español en Brasil. In: SEDYCIAS, J. (Org.) O ensino do espanhol no Brasil: passado, presente, futuro. São Paulo: Parábola Editorial, 2005.

NICOLAIDES, C. Interação em sala de aula de língua estrangeira: uma experiência na escola de primeiro grau. 1996, 182 f. Dissertação (Mestrado em Letras), UFPEL, Pelotas, 1996.

; TÍLIO, R. C. Políticas de ensino e aprendizagem de línguas adicionais no contexto brasileiro: o caminho trilhado pela ALAB. In: NICOLAIDES, C. S.; ROCHA, C. H.; SILVA K. A.; TÍlIO, R. C. (Orgs.) Política e Políticas Linguísticas. Campinas, SP: Pontes Editores, 2013, pp. 285-305. 
NOVODVORSKI et al. A REALIDADE DE DUAS ESCOLAS DE LÍNGUA ESPANHOLA NA CIDADE DE UBERLÂNDIA: UM ESTUDO COMPARATIVO. A MARgem - Revista Eletrônica de Ciências Humanas, Letras e Artes, ano 3, nº 5, pp. 31-41, jan/jun. 2010.

OLIVEIRA, A. F. POLÍTICAS PÚBLICAS EDUCACIONAIS: conceito e contextualização numa perspectiva didática. In: OLIVEIRA, A. F.; PIZZIO, G. \& FRANÇA. Fronteiras da Educação: desigualdades, tecnologias e políticas, Editora da PUC Goiás, 2010, pp. 93-99.

OLIVEIRA, A. V. B. H. de. AS POLÍticAS LINGUÍSTICAS E O ENSINO DE LÍNGUA ESPANHOL NA GESTÃo PÚBLICA. In: CIPLOM, Vol.1, 2010, Foz do Iguaçu. Anais... Foz do Iguaçu, 2010, p. 50-59.

OLIVEIRA, G. M. prefácio. In: CALVET, L-J. As políticas linguísticas. Florianópolis e São Paulo: IPOL/Parábola, 2007, 166 p.

ORLANDI, E. P. (org). Política Linguística na América Latina. Campinas: Pontes, 1988. (org). Política Linguística no Brasil. Campinas, SP: Pontes, 2007.

ORTÍZ ALVAREZ, M. L. A DIMENSÃO CULTURAL NO ENSINO DE PORTUGUÊS PARA FALANTES DE RUSSO: CONSTRUINDO PONTES. Acta Semiótica et Lingvistica. Vol. 15, ano 34, n. 1, 2010, pp. 117-135. Disponível em: <periódicos.ufpb.br/ojs/index.php/actas/article/view/14651>. Acesso em 20 set. 2014.

PAIVA, V. L. M. O. Como o sujeito vê a aquisição de segunda língua In: CORTINA, A.; NASSER. S.M.G.C. Sujeito e Linguagem. São Paulo: Cultura Acadêmica, 2009.

Reflexões sobre ética na pesquisa. Revista Brasileira de Linguística Aplicada. Belo Horizonte. v. 5, n.1. pp. 43-61, 2005.

PARAQUETT, M. O PAPEL QUE CUMPRIMOS OS PROFESSORES DE ESPANHOL COMO LÍNGUA ESTRANGEIRA (E/LE) NO BRASIL. Caderno de Letras da UFF Dossiê: Diálogos Interamericanos, $n^{\circ}$ 38, p. 123-137, 2009.

A língua espanhola e a linguística aplicada no Brasil. Abehache, ano 2, $n^{\circ} 2,1^{\circ}$ semestre, pp. 225-239, 2012.

PEDROSO, M. P. A. et al. O ensino do Espanhol como língua estrangeira: A Lei e suas repercussões. Maquinações. Universidade Estadual de Londrina, v.1, n.2, Outubro/Dezembro 2008.

PENNYCOOK, A. A linguística aplicada dos anos 90: em defesa de uma abordagem crítica. In: SGNORINI, I.; CAVALCANTI, M. (Org.). Linguística Aplicada e Transdiciplinaridade. Campinas: Mercado das Letras, 1998. pp. 21-46.

Uma linguística aplicada transgressiva. In: MOITA-LOPES, L. P. (Org.). Por uma Linguística Aplicada Indisciplinar. São Paulo: Parábola Editorial, 2006. pp. 67-83. 
PNLD 2011. Programa Nacional do Livro Didático- Ensino Fundamental. Edital. Brasília: FNDE, 2008. Disponível em: 〈http://www.fnde.gov.br/index.php/lista-de-consultasonline>. Acesso em: 10 ago. 2013.

PNLD 2012. Programa Nacional do Livro Didático - Ensino Médio. Edital. Brasília: FNDE, 2009. Disponível em: 〈http://www.fnde.gov.br/index.php/lista-de-consultas-online>. Acesso em: 10 ago. 2013.

PÓLIS. Política pública como garantia de direitos. Repente: Participação popular na construção do poder local. Pólis - Instituto de Estudos, Formação e Assessoria em Políticas Sociais. $n^{o}$ 26. Dez. 2006. Disponível em: 〈http://www.polis.org.br/uploads/1055/1055.pdf $>$. Acesso em: 15 jul. 2014.

POUPART, J. A entrevista do tipo qualitativo: considerações epistemológicas, teóricas e metodológicas. In: POUPART, J. et al. A pesquisa qualitativa: enfoques epistemológicos e metodológicos. Petrópolis, Vozes, 2008, pp. 215-253.

RAJAGOPALAN, K. Por uma linguística crítica: Linguagem, identidade e a questão ética. São Paulo: Parábola Editorial, 2003.

Repensar o papel da Linguística Aplicada. In: MOITA LOPES, L.P. (Org.). Por uma Linguística Aplicada Indisciplinar. São Paulo: Parábola, 2006. pp. 149-166.

Resenha. D.E.L.T.A., 24:1, 2008, p. 135-139. Disponível em: 〈http://www.scielo.br/pdf/delta/v24n1/v24n1a08.pdf >. Acesso em: 15 jul. 2014.

Política Linguística: do que se trata, afinal? In: NICOLAIDES, C. S.; ROCHA, C. H.; SILVA K. A.; TÍlIO, R. C. (Orgs.). Política e Políticas Linguísticas. Campinas, SP: Pontes Editores, 2013, pp. 11-42.

RAMPTON, B. Continuidade e mudança nas visões de sociedade em Linguística Aplicada. In: MOITA LOPES, L.P. (Org.). Por uma Linguística Aplicada Indisciplinar. São Paulo: Parábola, 2006. pp. 109-128.

REATTO, D.; BISSACO, C. M. O ENSINO DO ESPANHOL COMO LÍNGUA ESTRANGEIRA: UMA DISCUSSÃO SÓCIO-POLÍTICA E EDUCACIONAL. Letra Magna, ano 4, $\mathrm{n}^{\circ}$ 7, pp. 1-13, $2^{\circ}$ semestre de 2007.

RENÓ, A. F. S; CARVALHO, J. P; MESQUITA, P. P. P. FORMAÇÃO DE PROFESSORES DE ESPANHOL NO DISTRITO FEDERAL: UMA HISTÓRIA RECENTE. In: Colóquio do GEPPELE, 2, 2013, Fortaleza. Anais... Fortaleza, UFC, 2013, p. $141-156$.

RINALDI, S. O ESPANHOL NAS ESCOLAS PÚBLICAS BRASILEIRAS. In: DIREITOS À APRENDIZAGEM DA LÍNGUA ESPANHOLA NA EDUCAÇÃO BÁSICA. Ano XXIV, Boletim 2, mai. 2014, pp. 10-16.

RODRIGUES, F. S. C. Língua viva, letra morta: obrigatoriedade e ensino de espanhol no arquivo jurídico e legislativo brasileiro. 2010. 342 f. Tese (Doutorado - Programa de Pós- 
graduação em Língua Espanhola e Literaturas Espanhola e Hispano-Americana) - Faculdade de Filosofia, Letras e Ciências Humanas da Universidade de São Paulo, 2010a.

Leis e línguas: o lugar do espanhol na escola brasileira. In: BARROS, C. S.; COSTA, E. G. M. (Org.). Espanhol Ensino médio. Coleção Explorando o Ensino. Brasília: Ministério da Educação, Secretaria de Educação Básica, 2010b, pp. 13-24.

As línguas estrangeiras na legislação educacional brasileira de 1942 a 2005. In: BARROS, C. S.; COSTA, E. G. M. (Orgs.) Se hace caminho al andar: reflexões em torno do ensino de espanhol na escola. Belo Horizonte: Faculdade de Letras da UFMG, 2012, pp. 23-35.

ROJO, R. H. R. Fazer linguística aplicada em perspectiva sócio-histórica: Privação sofrida e leveza de pensamento. In: MOITA LOPES, L.P. (Org.). Por uma Linguística Aplicada Indisciplinar. São Paulo: Parábola, 2006. pp. 253-276.

Caminhos para a LA: Política Linguística, Política e Globalização. In: NICOLAIDES, C. S.; ROCHA, C. H.; SILVA K. A.; TÍlIO, R. C. (Orgs.). Política e Políticas Linguísticas. Campinas, SP: Pontes Editores, 2013, pp. 63-78.

ROSA, M.V. F. P. C. \& ARNOLDI, M. A. G. C. A entrevista na pesquisa qualitativa. Belo Horizonte: Autêntica, 2006.

SALVADOR, A. C. O; SANTOS, L. V. O ensino de espanhol na educação básica brasileira: uma retrospectiva histórica. Disponível em: <http://www.cchla.ufrn.br/humanidades/ARTIGOS/GT38/O\%20ENSINO\%20DE\%20ESPA

NHOL\%20NA\%20EDUCACAO\%20BASICA\%20BRASILEIRA\%20UMA\%20RETROSPE CTIVA\%20HISTORICA.pdf.>. Acesso em: 03 Set. 2012.

SANTOS, H. S. O papel de estereótipos e preconceitos na aprendizagem de línguas estrangeiras. In: CONGRESO BRASILEÑO DE HISPANISTAS, 2., 2002, São Paulo. Anais... Disponível

em:

$\leq$ http://www.proceedings.scielo.br/scielo.php?script=sci_arttext\&pid=MSC00000000120020 00100029\&lng=en\&nrm=iso>. Acesso em: 02 ago. 2014.

SANTOS, L. I. S. Crenças acerca da inclusão de língua inglesa nas séries iniciais: quanto antes melhor? 2005. Dissertação (Mestrado em Estudos de Linguagem) - Instituto de Linguagens, Universidade Federal de Mato Grosso, Cuiabá, 2005.

SCHWANDT, T. A. Três posturas epistemológicas para a investigação qualitativa. In: DENZIN, N. K. \& LINCOLN, Y. S. (Orgs.). O planejamento da pesquisa qualitativa: teorias e abordagens. Porto Alegre: Artmed, 2006. pp. 193-217.

SEDYCIAS, J. (Org.) Ensino do espanhol no Brasil: passado, presente, futuro. $1^{\text {a }}$ Ed. São Paulo: Parábola Editorial, 2005.

SEVERO, C. G. POLÍTICA(S) LinguístiCA(S) E QUESTÕES DE PODER. Alfa, São Paulo, 57 (2), pp. 451-473, 2013. 
SIGNORINI, I.; CAVALCANTI, M. (Org.). Linguística Aplicada e Transdiciplinaridade. Campinas: Mercado das Letras, 1998.

SILVA, E. R. da. "[...] você vai ter que aprender inglês de qualquer jeito, querendo ou não!": exames de línguas e política linguística para o inglês no Brasil. 194 f. Tese (Doutorado em Linguística Aplicada) - Programa de Pós-Graduação em Linguística Aplicada - Instituto de Estudos da Linguagem, Universidade Estadual de Campinas, Campinas, 2011.

SILVA, K. A. da. O professor mediador e os interagentes (brasileiro e estrangeiro) no projeto "Teletandem Brasil: línguas estrangeiras para todos": legitimação de crenças e/ou reconstrução de competências? 2010. 283 f. Tese (doutorado) - Universidade Estadual Paulista, Instituto de Biociências, Letras e Ciências Exatas, São José do Rio Preto: [s.n], 2010.

SOUZA, C. Políticas públicas: uma revisão da literatura. Sociologias, Porto Alegre, ano 8, n. 16, p. 20-45 jul/dez. 2006.

SOUZA, F. M. de. Espanhol-língua estrangeira para brasileiros: políticas de difusão e formação de professores no Estado de São Paulo. 2009, 131f. Dissertação (Mestrado em Educação) - Faculdade de Filosofia e Ciências, Universidade Estadual Paulista, 2009.

SOUZA, S. A. F. de. O movimento dos sentidos sobre as línguas estrangeiras no Brasil: discurso, história e educação. Campinas: IEL/Unicamp. Tese de doutorado, 2005.

STAKE, R. Estudo de caso em pesquisa e avaliação educacional. Educação e seleção. São Paulo: Fundação Carlos Chagas, nº 7, jan/jun. 1983.

The Art of Case Study Research. SAGE Publications, 1995.

TRATADO de Assunção, 1991. Disponível em: <http://sicmercosul.mec.gov.br/asp/Planos/compro_brasilia.asp.>. Acesso em: 08 abr. 2013.

TENORIO-MEJÍA, R. Política Linguística e Política de Ensino de Espanhol no Brasil. Dissertação de mestrado. Brasília: UNB, 1998.

TERAN, A. T. L. A PRESENÇA DA DISCIPLINA LÍNGUA ESTRANGEIRA MODERNA ESPANHOL NO CURRÍCULO ESCOLAR NO BRASIL: UM ESTUDO

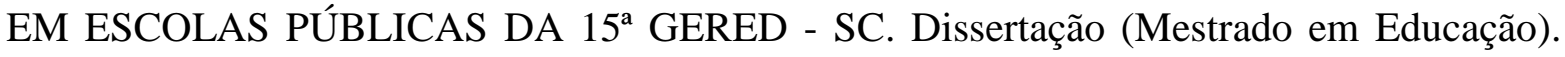
FURB, Blumenau, 2012.

UNESCO. Declaração Universal dos Direitos Linguísticos. Barcelona (1996). Disponível em: 〈http://www.letras.ufscar.br/linguasagem/edicao20/pdfs/declaracao.pdf >. Acesso em: 10 jul 2014.

VESZ, F. Z. Crenças sobre o espanhol na escola pública: bem vindos ao mundo dos sonhos e das [im]possibilidades. Dissertação (mestrado). Universidade Federal de Mato Grosso, Instituto de Linguagens, Pós-Graduação em Linguagem, Área de Concentração: Estudos Linguísticos, 2012. 
VIEIRA-ABRAHÃO, M. H.; ALMEIDA FILHO, J. C. P. de; BOHN, H. I. (Comissão de redação). Carta de Pelotas. Pelotas, 2000. Disponível em: <http://www.ipol.org.br/ler.php?cod=132>. Acesso em: 26 nov. 2013.

VIEIRA, R. Novos rumos para a Linguística Aplicada Contemporânea. Revista Odisséia, n. 3, UFRN, 2009. Disponível em: 〈www.periodicos.ufrn.br/odisseia/article/view/2052/1486>. Acesso em: 04 ago. 2013.

VIÑAL JÚNIOR, J. V. POSSÍVEL PROCESSO DE EXCLUSÃO SOCIAL GERADO PELA NÃO OFERTA OU OFERTA IRREGULAR DA LÍNGUA ESPANHOLA NO BRASIL: REFLEXÕES A PARTIR DE ESCRITOS DE ROLAND BARTHES E MICHAEL FOUCAULT SOBRE O PODER. Litteris, ano 4, nº 9, p. 8-24, mar. 2012a.

ENSEÑANZA DEL ESPAÑOL EN BRASIL CENTRADA EN LA COMPRESIÓN LECTORA SEGÚN RECOMENDACIONES DE LOS PARÁMETROS CURRICULARES NACIONALES DE LENGUA EXTRANJERA (PCNS LE): UNA FORMACIÓN INCOMPLETA DEL ALUMNADO Y UNA PUERTA PARA LA DESIGUALDAD. In: HISPANISTA, Vol XIII n n 50. Julio - Agosto - Septiembre, 2012b.

WALLACE, M. Action research for language teachers. Cambridge: Cambridge University Press, 1998.

YIN, R. K. Estudo de caso: planejamento e métodos. Tradução Ana Thorell. 4. ed. Porto Alegre: Bookman, 2010.

\section{LEGISLAÇÃO:}

BRASIL. Constituição da República Federativa do Brasil, de 05 de outubro de 1988.

Conselho Nacional de Educação. Resolução CP 2/2002, de 19 de fevereiro de 2002. Disponível em: sportal.mec.gov.br/cne/arquivos/pdf/CP022002.pdf>. Acesso em: 24 nov. 2013.

Decreto $\mathbf{n}^{0} \mathbf{1 1 . 5 3 0}$ de 18 de março de 1915. Disponível em: 〈http://www2.camara.leg.br/legin/fed/decret/1910-1919/decreto-11530-18-marco-1915522019-republicacao-97760-pe.html>. Acesso em: 05 jul. 2014.

Decreto $\mathrm{n}^{0}$ 16.782-A de 13 de janeiro de 1925. Disponível em: $<$ https://www.planalto.gov.br/ccivil_03/decreto/1910-1929/d16782a.htmDECRETON 16.782-A, DE 13 DE JANEIRO DE 1925>. Acesso em: 05 jul. 2014.

Decreto $\mathrm{n}^{\circ} \mathbf{1 8 . 5 6 4}$ de 15 de janeiro de 1929. Disponível em: <http://www2.camara.leg.br/legin/fed/decret/1920-1929/decreto-18564-15-janeiro1929502422-publicacaooriginal-1-pe.html>. Acesso em: 05 jul. 2014.

Decreto $\mathrm{n}^{0} \mathbf{1 9 . 8 9 0}$ de 18 de abril de 1931. Disponível em: <http://www2.camara.leg.br/legin/fed/decret/1930-1939/decreto-19890-18-abril-1931504631-publicacaooriginal-141245-pe.html>. Acesso em: 05 jul. 2014. 
Decreto $\mathbf{n}^{\mathbf{0}} \mathbf{2 0}$ de dezembro de 1837. Disponível em: $<$ http://www2.camara.leg.br/legin/fed/decret_sn/1824-1899/decreto-36979-2-dezembro-1837562344-publicacaooriginal-86295-pe.html > . Acesso em: 05 jul. 2014.

Decreto $\mathrm{n}^{0} \mathbf{1 9 . 0 4 0}$ de 18 de fevereiro de 1998. Disponível em: <www.sedhab.df.gov.br/cocoe/Biblioteca/Decreto1904098.pdf. . . Acesso em: 07 nov. 2013.

Decreto $\mathbf{n}^{0} \mathbf{8 . 1 6 6}$ de 23 de dezembro de 2013. Disponível em: <www.planalto.gov.br/CCIVIL_03/Ato2011-2014/2013/Decreto/D8166.htm>. Acesso em: 05 de julho de 2014.

Decreto-lei $\mathrm{n}^{\circ} \mathbf{4 . 2 4 4}$ de 9 de abril de 1942. Disponível em: <http://www2.camara.leg.br/legin/fed/declei/1940-1949/decreto-lei-4244-9-abril-1942414155-publicacaooriginal-1-pe.html>. Acesso em: 08 jul. 2014.

Decreto-lei $\mathrm{n}^{0}$ 11.161, de 05 de agosto de 2005. Disponível em: <www.planalto.gov.br/ccivil_03/_Ato2004-2006/2005/Lei/11161.htm>. Acesso em: 24 nov. 2012.

Lei $\mathbf{n}^{\mathbf{0}}$ 3.674, de 7 de janeiro de 1919. Disponível em: <http://www2.camara.leg.br/legin/fed/lei/1910-1919/lei-3674-7-janeiro-1919570619 publicacaooriginal-93752-pl.html>. Acesso em: 05 jul. 2014.

$$
\text { Lei } \mathrm{n}^{\mathbf{4}} \mathbf{4 . 0 2 4} \text { de } 1961 . \quad \text { Disponível em: }
$$

<http://www2.camara.leg.br/legin/fed/lei/1960-1969/lei-4024-20-dezembro-1961-353722publicacaooriginal-1-pl.html>. Acesso em: 08 jul. 2014.

Lei $\quad \mathbf{n}^{\circ} \mathbf{5 . 6 8 2}$ de 1971 Disponível em:

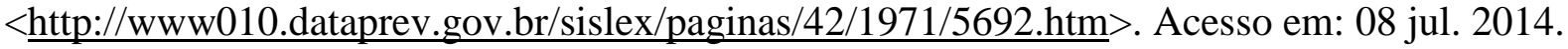

Lei $\mathbf{n}^{0} \mathbf{9 . 3 9 4}$ de 20 de dezembro de 1996. Disponível em: 〈http://www.camara.gov.br>. Acesso em: 14 abr. 2014.

<www.conteudojuridico.com.br>. Acesso em: 14 nov. 2013.

Parecer n ${ }^{0}$ 18/2007 do Conselho Nacional de Educação/Câmara do Ensino Básico (CNE/CEB), 2002. Disponível em:

〈http://portal.mec.gov.br/cne/arquivos/pdf/2007/pceb018_07.pdf >. Acesso em: 10 ago. 2014.

Regulamento $\mathrm{n}^{\mathbf{0}} \mathbf{8}$ de 31 de janeiro de 1838. Disponível em: $<$ http://www.histedbr.fae.unicamp.br/navegando/fontes_escritas/3_Imperio/regulamento\%20n $\% 208 \% 20-1838 \% 20 \% 20$ estatutos\%20para\%20o\%20col\%20pedro\%20ii.pdf $>$. Acesso em: 05 jul. 2014.

〈http://www.camara.gov.br $\rangle$. Acesso em: 08 jul 2014. 
CÂMARA DOS DEPUTADOS. Exposição de motivos $\mathbf{n}^{\mathbf{7}} \mathbf{7 4 5 / 1 9 5 8}$. Projetos de Leis e outras proposições, 1958a. Disponível em: $<$ http://imagem.camara.gov.br/Imagem/d/pdf/DCD16OUT1958.pdf\#page=20>. Acesso em: 15 jul. 2014.

Disponível

Mensagem $\mathbf{n}^{\mathbf{0}}$ 327-58/1958. Projetos de Leis e outras proposições, $1958 \mathrm{~b}$. <http://imagem camara gov br/Imagem/d/pdf/DCD16OUT1958 pdf\#page=20>. Acesso 15 jul. 2014.

Disponível

Projeto de Lei, 4606/1958. Projetos de Leis e outras proposições, 1958c. <http://imagem.camara.gov.br/Imagem/d/pdf/DCD16OUT1958.pdf\#page=20>. Acesso em: 15 jul. 2014.

Projeto de Lei, 3987/2000. Diário da Câmara dos Deputados: suplemento, 10 de março de 2001. Disponível em: 〈www.camara.gov.br>. Aceso em: 15 fev. 2013.

CÂMARA LEGISLATIVA DO DISTRITO FEDERAL. Lei no 3.694 de 08 de novembro de 2005. Disponível

em: <legislação.cl.df.gov.br/Legislacao/consultaTextoLeiParaNormaJuridicaNJUR113927!buscar TextoLeiParaNormaJuridicaNJUR.action>. Acesso em: 02 jul. 2014.

ESTADO DE MINAS GERAIS. Orientação DEMP/SEM/SB N 01/2009. Disponível em: <http://200.198.28.154/sistema44/PROJETOS/TRANSFER/SEMP/Medio/conteudo/Orienta \%20a\%20inclus\%E3o\%20da\%20L\%EDngua\%20Espanhola\%20.pdf.>. Acesso em: 02 ago. 2014.

SUPREMO TRIBUNAL FEDERAL. ADI 3669. Disponível em: sstf.jusbrasil.com.br/jurisprudência/756822/acao-direta-de-inconstitucionalidade-adi 3669-

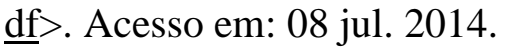

\section{REPORTAGENS:}

EL PAÍS. O ensino de espanhol ainda é uma matéria pendente no Brasil. Disponível em: $<$ http://brasil.elpais.com/brasil/2013/12/14/politica/1386980073 433747.html >. Acesso em: 10 ago. 2014.

FOLHA UOL. Obrigatório em 2010, Espanhol é ensinado hoje a só $15 \%$ dos alunos. Disponível em: $\leq$ http://www1.folha.uol.com.br/folha/educacao/ult305u606905.shtml>. Acesso em: 10 ago. 2014.

VALOR ECONÔMICO. Lei do espanhol ficou no papel. Disponível em: 〈http://profissaomestreegestaoeducacional.blogspot.com.br/2010/01/espanholobrigatorio.html >. Acesso em: 10 ago. 2014. 


\section{APÊNDICE A - TERMO DE CONSENTIMENTO (DIRETOR/A)}
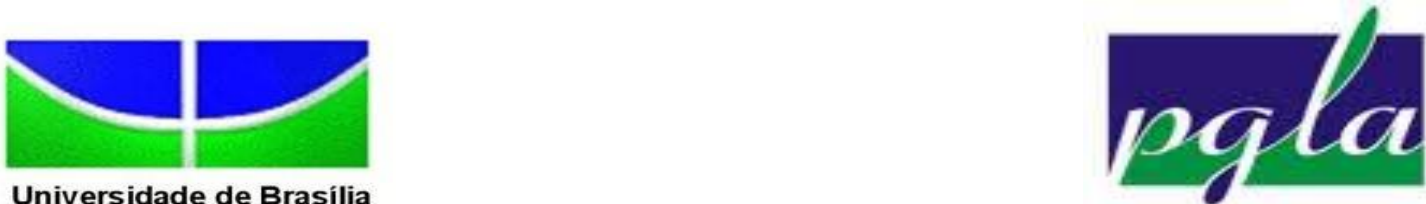

Universidade de Brasília

Termo de Consentimento Livre e Esclarecido

Brasília, abril de 2014.

$\mathrm{Eu}$,

Diretor (a) da escola da Secretaria de Educação do Distrito Federal, autorizo a aplicação da pesquisa intitulada "Contrastes e reflexões sobre o ensino de Espanhol em escolas públicas do DF: Uma visão real acerca da implantação da lei 11.161/2005" nesta instituição de ensino, bem como a divulgação das informações concedidas à pesquisadora Julyana Peres Carvalho, aluna regular do Programa de Pós-Graduação em Linguística Aplicada da Universidade de Brasília (PPGLA - UnB), sob a orientação da professora Dra. Maria Luisa Ortíz Alvarez. A divulgação poderá ser de forma impressa e/ou virtual, em congressos, encontros e em qualquer evento de natureza acadêmico-científica.

Data e assinatura

Número do RG: 


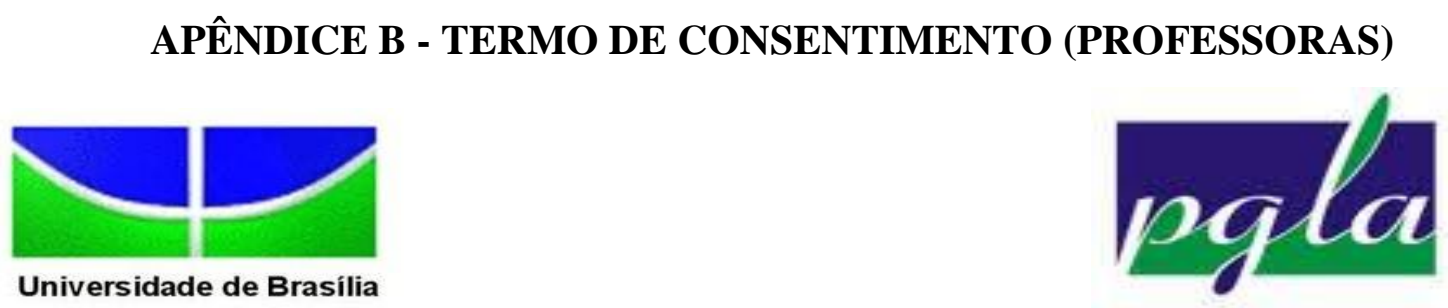

Termo de Consentimento Livre e Esclarecido

Brasília, abril de 2014.

Termo de Consentimento Livre e Esclarecido

$\begin{array}{llllll} & & & & \text { Eu, } & \text { professor (a) da Secretaria } \\ \text { de } & \text { Educação do Distrito Federal da instituição de ensino }\end{array}$ , autorizo a divulgação das informações cedidas em questionários, entrevistas e observações à pesquisadora Julyana Peres Carvalho; aluna do Programa de Pós-Graduação em Linguística Aplicada da Universidade de Brasília (PPGLA - UnB), sob a orientação da professora Dra. Maria Luiza Ortíz Alvarez. Tais informações são referentes à aplicação da pesquisa intitulada: "Contrastes e reflexões sobre o ensino de Espanhol em escolas públicas do DF: Uma visão real acerca da implantação da lei 11.161/2005". A divulgação poderá ser impressa e/ou virtual, em congressos, encontros e em qualquer evento de natureza acadêmico-científico.

Data e assinatura

Número do RG: 


\section{APÊNDICE C - TERMO DE CONSENTIMENTO (ALUNOS)}
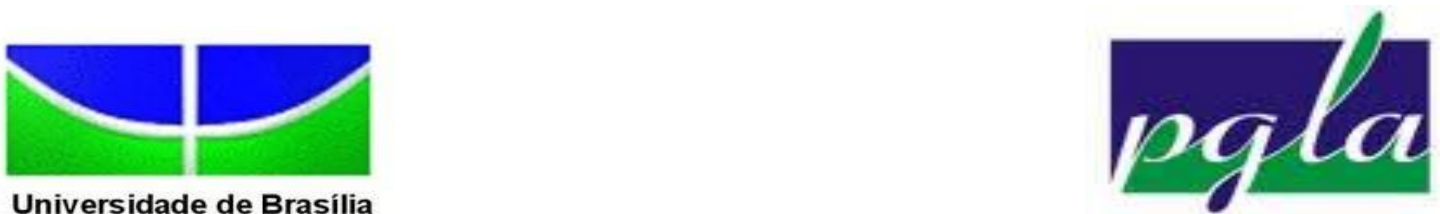

Universidade de Brasília

Termo de Consentimento Livre e Esclarecido

Brasília, abril de 2014.

Termo de Consentimento Livre e Esclarecido

$\mathrm{Eu}$, , aluno (a) da instituição de ensino da Secretaria de Educação do Distrito

Federal, autorizo a divulgação das informações cedidas à pesquisadora Julyana Peres Carvalho; aluna regular do Programa de Pós-Graduação em Linguística Aplicada da Universidade de Brasília (PPGLA - UnB), sob a orientação da professora Dra. Maria Luiza Ortíz Alvarez. Tais informações são referentes à aplicação da pesquisa intitulada: “Contrastes e reflexões sobre o ensino de Espanhol em escolas públicas do DF: Uma visão real acerca da implantação da lei 11.161/2005”. A divulgação poderá ser impressa e/ou virtual, em congressos, encontros e em qualquer evento de natureza acadêmicocientífico.

Data e assinatura

Número do RG: 


\section{APÊNDICE D - TERMO DE CONSENTIMENTO (ALUNOS MENORES DE IDADE)}
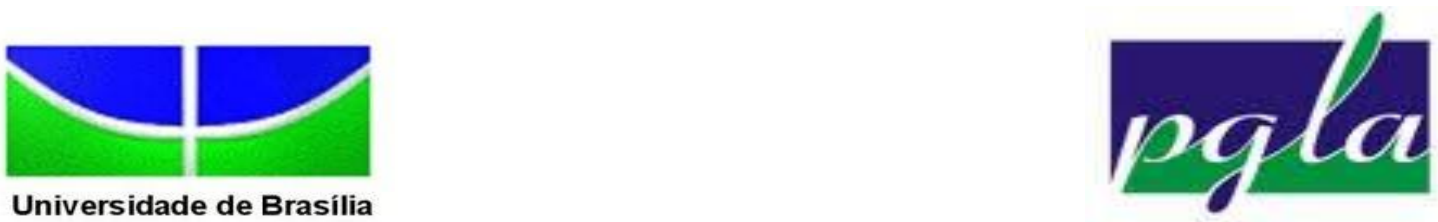

Termo de Consentimento Livre e Esclarecido

Brasília, abril de 2014.

Termo de Consentimento Livre e Esclarecido

$\mathrm{Eu}$, responsável pelo (a) aluno (a) matriculado

(a) na escola , autorizo a divulgação das informações referentes aos questionários e observações, relativas à aplicação da pesquisa intitulada: "Contrastes e reflexões sobre o ensino de Espanhol em escolas públicas do DF: Uma visão real acerca da implantação da lei 11.161/2005", cedidas à pesquisadora Julyana Peres Carvalho, aluna regular do Programa de Pós-Graduação em Linguística Aplicada da Universidade de Brasília (PPGLA - UnB), sob a orientação da professora Dra. Maria Luiza Ortíz Alvarez. A divulgação poderá ser impressa e/ou virtual, em congressos, encontros e em qualquer evento de natureza acadêmico-científico.

Data e assinatura

Número do RG: 


\title{
APÊNDICE E - QUESTIONÁRIO ESCOLAS
}

\author{
DADOS - ESCOLAS
}

Data:

Nome da escola:

Endereço:

Telefone:

DADOS REFERENTES AO ENSINO DE ESPANHOL NA ESCOLA:

A escola atua em regime de semestralidade?

Carga horária da disciplina:

Ano de implantação da lei 11.161 na escola:

$\mathrm{O}$ aluno pôde optar em estudar a língua?

A escola desenvolve algum projeto referente ao ensino de Espanhol ou língua estrangeira com os alunos? Se sim, qual?

A disciplina é parte diversificada?

A disciplina reprova? Em quais condições?

DADOS REFERENTES AOS DOCENTES DE LÍNGUA ESPANHOLA:

Quantos professores de Espanhol há na escola?

PERFIL DO PROFESSOR

\begin{tabular}{|l|l|l|l|l|l|l|}
\hline PROFESSOR & $\begin{array}{c}\text { Efetivo ou } \\
\text { contrato? }\end{array}$ & $\begin{array}{c}\text { Área de } \\
\text { concurso }\end{array}$ & $\begin{array}{c}\text { Tempo } \\
\text { de } \\
\text { serviço } \\
\text { na } \\
\text { SEEDF }\end{array}$ & $\begin{array}{c}\text { Possui } \\
\text { especialização? }\end{array}$ & $\begin{array}{c}\text { Ministra quais } \\
\text { disciplinas? }\end{array}$ & $\begin{array}{c}\text { Número } \\
\text { de } \\
\text { turmas }\end{array}$ \\
\hline PROFESSOR 1 & & & & & & \\
\hline PROFESSOR 2 & & & & & & \\
\hline PROFESSOR 3 & & & & & & \\
\hline PROFESSOR 4 & & & & & & \\
\hline PROFESSOR 5 & & & & & & \\
\hline
\end{tabular}

SALA DE COORDENAÇÃO

Há computadores para o professor?

Há acesso a internet para o professor?

Há impressora para o professor?

O professor tem acesso a copias para exercícios? De maneira ilimitada ou limitada?

Há materiais disponíveis na língua na sala de coordenação? 


\section{DADOS REFERENTES A RECURSOS E MATERIAIS DIDÁTICOS MATERIAL IMPRESSO}

A escola possui:

Dicionários suficientes para que os alunos utilizem em sala?

Livros de literatura na língua estudada?

Gramáticas e livros didáticos a disposição do aluno?

Revistas e periódicos na língua?

\section{MATERIAL DE APOIO TECNOLÓGICO}

Há laboratório de informática na escola? Está sendo utilizado?

Os computadores estão em bom uso?

Há algum professor responsável pela sala?

Há sala multimídia?

Há disponibilidade de televisão, dvd e data show?

É necessário marcar horário ou há esses recursos nas salas?

A sala é ambiente (alunos que trocam)?

CONDIÇÕES GERAIS DE ENSINO - AMBIENTE

Sala de aula:

Escola (maneira geral):

\section{Observações pertinentes:}




\section{APÊNDICE F - ENTREVISTA (PROFESSORES E ASSISTENTES)}
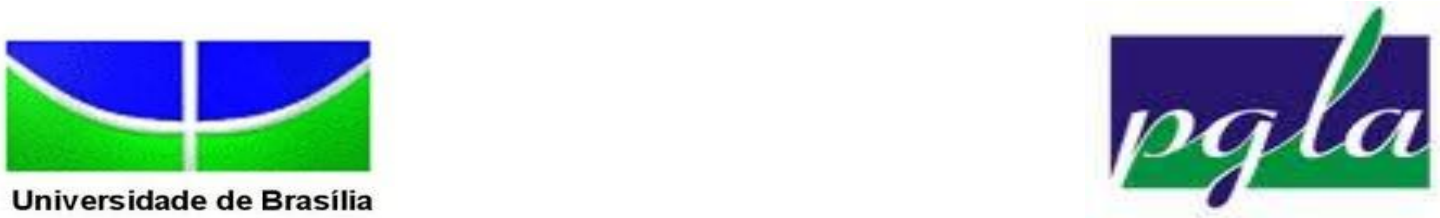

Querido (a) professor (a),

Meu nome é Julyana Carvalho e sou aluna do curso de Pós-Graduação em Linguística Aplicada da Universidade de Brasília. Minha pesquisa nasceu do sonho de, como pesquisadora e professora de Espanhol da Secretaria de Educação do Distrito Federal, contribuir para a melhoria da realidade e ensino de Espanhol em escolas públicas. Compartilho de sua realidade, e almejo com esta pesquisa demonstrar os sucessos deste ensino, bem como suas necessidades e dificuldades.

Para que isso seja possível, necessito muito de sua ajuda e participação. Ninguém melhor que você, que está em sala de aula, para avaliar esta realidade de ensino. Desse modo, peço encarecidamente que responda as perguntas abaixo de maneira mais sincera possível, e envie as respostas para meu e-mail: julyanapcarvalho@gmail.com. Caso você queira conversar comigo pessoalmente, ou me contar sua experiência como professor (a) de Espanhol na Secretaria de Educação, não hesite em entrar em contato comigo através do email disponibilizado. Sua ajuda será muito importante e vital para o sucesso desta pesquisa. Desde já agradeço sua preciosa colaboração!

\section{Perguntas}

1) Em sua visão, por qual/quais motivo(s) o Espanhol foi acrescentado ao currículo das escolas públicas?

2) Como professor, quais as suas satisfações em relação ao ensino de Espanhol em escolas públicas do Distrito Federal?

3) Quais as suas insatisfações (dificuldades) em relação ao ensino de Espanhol em escolas públicas do Distrito Federal? De que maneira essas dificuldades prejudicam o ensino-aprendizagem?

4) Em sua opinião, como seria a realidade ideal de ensino de Espanhol em escolas públicas do Distrito Federal?

5) Que medidas poderiam ser tomadas para a melhoria do ensino de Espanhol em escolas públicas do Distrito Federal? 


\section{APÊNDICE G - QUESTIONÁRIO (ALUNOS)}
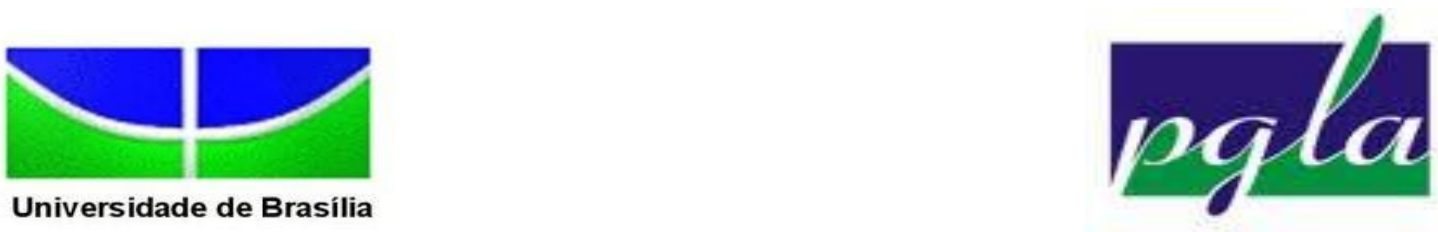

\section{Questionário - Aluno}

Brasília, abril de 2014.

Querido aluno participante desta pesquisa,

Este primeiro questionário, aplicado no início desta investigação, tem como objetivos saber sua opinião sobre a importância da Língua Espanhola, levantar informações sobre os seus conhecimentos obtidos nas aulas de Espanhol na escola até este momento e identificar suas expectativas e necessidades em relação ao ensino de Espanhol na escola.

1. É importante estudar espanhol na escola? Por quê?

2. Em sua visão, qual é o seu conhecimento de Espanhol desde o primeiro ano do ensino médio até agora?
a) Nenhum
b) Pouco
c) Razoável
d) Mediano
e) Acima da media
f) Excelente

3. Você acredita que é possível aprender espanhol na escola? Por quê?

4. Você gosta de ter aulas de espanhol na escola? Por quê?

5. Suas aulas na escola são motivadoras? Por quê?

6. O que te deixa motivado nas aulas de espanhol?

7. O que te deixa desmotivado nas aulas de Espanhol?

8. Como você gostaria que fossem suas aulas de Espanhol?

9. Você acredita que o tempo para as aulas de Espanhol na sua escola é suficiente para estudar a língua? Por quê?

10. Qual será a sua língua de opção no vestibular/PAS/ENEM? Por quais motivos você escolheu esta língua? 


\section{APÊNDICE H - AMOSTRA DE EXCERTO DE FALAS}

1) Em sua visão, por qual/quais motivo(s) o Espanhol foi acrescentado ao currículo das escolas públicas?

P2ET2: Eu acho porque o Espanhol tem tido uma importância a mais pro Brasil, devido ao MERCOSUL; devido às empresas multinacionais, ao setor de turismo, de hotelaria, enfim, é uma língua que está crescendo bastante não só aqui, mas no mundo, né, está quase sendo a segunda língua mais falada. Tem o Inglês, e tem entre o Espanhol e o Mandarim, então o Espanhol tem crescido também, tendo uma relevância.

2) Como professor, quais as suas satisfações em relação ao ensino de Espanhol em escolas públicas do Distrito Federal?

P2ET2: A minha maior satisfação é saber que, por exemplo, um aluno, ele se interessou para aprender a língua espanhola não só aqui na escola, porque a gente sabe que, por causa, pelo tempo, não dá tempo dele aprender muita coisa... Mas aí a minha maior satisfação é eu abrir o olhar do meu aluno pra ele saber que ele tem que estudar um outro idioma, ele saber que o mercado de trabalho está cada vez. mais exigente, enfim.

3) Quais as suas insatisfações (dificuldades) em relação ao ensino de Espanhol em escolas públicas do Distrito Federal? De que maneira essas dificuldades prejudicam o ensino-aprendizagem?

P2ET2: Dificuldades. Muitas dificuldades. Uma é a questão do tempo. É um horário só pra cada turma, eu tenho o total de 28 turmas, e só tem eu de professora do vespertino, é um professor por cada turno, então a gente tem todas as turmas e um horário. Então os alunos mal entram na sala e já saem! Então até eles entrarem, se sentarem, se arrumarem, e assim, tem muitos que levam de qualquer jeito, porque não tem um tempo adequado pra gente estar trabalhando a disciplina... E enfim, a gente fica cansada porque é um esforço muito... Muito a mais do que os outros professores, né, porque nós somos considerados anormais aqui na escola, porque a gente tem que fazer de tudo um pouco, e são muitos diários e são muitas turmas, essa é minha principal dificuldade... Porque se eu tivesse mais tempo, eu sei que não pra mim, pra mim também, mas pro aluno, eles aprenderiam muito mais, e se interessariam muito mais pela disciplina... Tanto que tem alguns que já preferem o Espanhol do que o próprio Inglês, e aí eles perguntam pra mim: "por que que não pode ser dois horários de Espanhol e tem que ser dois de Inglês?”. Ou por exemplo, aqui na escola nós estamos enfrentando alguns problemas de falta de professores. Então, por exemplo, o projeto (PD), não tem ainda, a Regional ainda não mandou professores, aí a gente tem que ficar só com um, só com um horário e mesmo assim, os alunos ficam sem fazer nada... Por exemplo, outro horário, aí eles ficam perguntando e eu não posso questionar, né... Seria pra trabalhar a disciplina de PD junto com o Espanhol, mas são áreas opostas, porque o PD seria como se fosse atualidades, por exemplo, e até agora nada de professores na escola e sem previsão também, porque está faltando professores temporários pra, segundo a informação que nos é passada na Regional, né... "Tá” faltando professores pra ocupar carência, e os próprios alunos, isso que eu acho interessante, os próprios alunos, 
não somos nós, professores, os próprios alunos reclamam que estão sem aula, que não tem professor, e por que que não faz, então, um horário duplo com Espanhol? Porque eles mesmos, eles vem, eles gostam, tem muitos que gostam e isso é uma satisfação pra mim, tem muitos que gostam e a aula passa tão rápido que eles ficam insatisfeitos.

4) Em sua opinião, como seria a realidade ideal de ensino de Espanhol em escolas públicas do Distrito Federal?

P2ET2: Pelo menos que ficasse com a carga horária junto com a do Inglês, né. Horário duplo, eu acho que seria bem interessante, ou de repente o aluno optasse por uma língua e ele quisesse estudar aquilo que ele quer né, porque a gente tem que visar o que o aluno quer, né... Não o que é imposto a ele...

5) Que medidas poderiam ser tomadas para a melhoria do ensino de Espanhol em escolas públicas do Distrito Federal?

P2ET2: Medidas práticas? Ahh... Eu penso que a forma como a Secretaria de Educação pode ajudar o professor e o aluno com materiais didáticos, atualizados sempre, tem ainda escolas que não têm o livro didático que eles podem levar pra casa. Tem aquelas escolas que falta livro didático... Por exemplo, aqui na escola a gente não sofre com isso, porque os alunos, eles têm o livro deles, e no final do ano eles podem levar pra casa deles, ou seja, como é só um horário, eles já fazem isso pra eles poderem fazer os exercícios no próprio livro, e pra economizar tempo... Mas é os usos de recursos, né, eu acho que seria mais prático um Datashow na sala, televisão, sempre está tendo esses recursos. Essa escola tem. Ajuda bastante, ainda mais porque, agora, eu imagino se fosse outra realidade, porque a minha realidade é essa. Graças a Deus eu tenho uma televisão na minha sala; eu tenho um cabo hdmi que eu posso estar trazendo meu notebook, enfim... Tem gente que não tem e já fica mais complicado, porque trabalhar só com o livro não vai alcançar, né, muita coisa, então, existem muitas escolas aí que não têm muitos recursos, ou estão quebrados, aí fica muito complicado, falta de verba... 


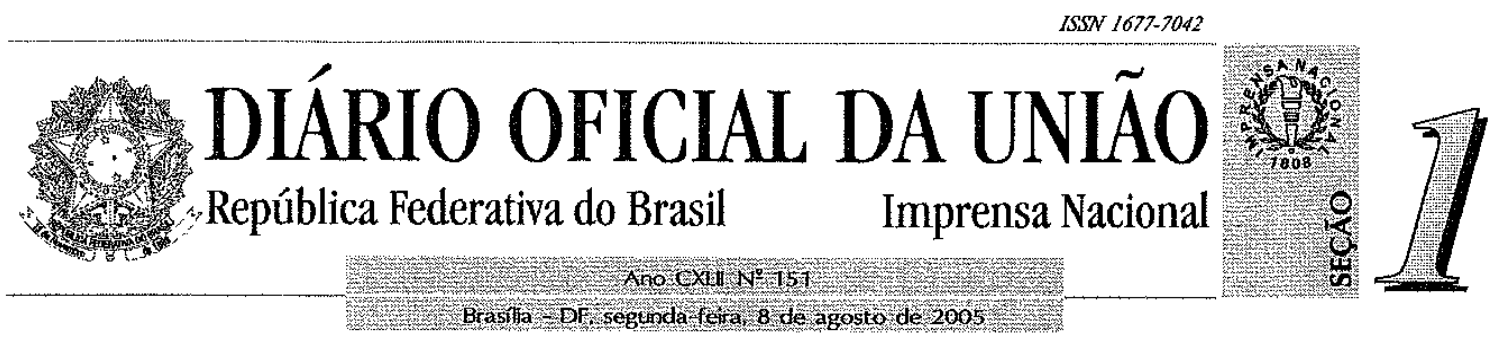

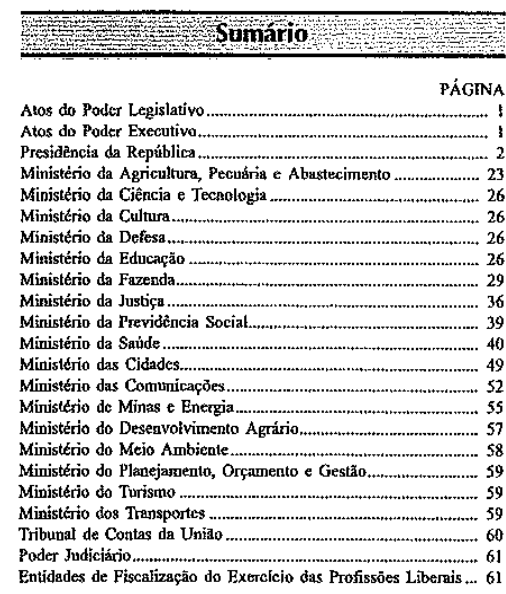

Entidades de Fiscaizaçăo do Exercício das Profissōes Libernis ... 61

Atos do oder Legislativo

LEY N² 11.161, DE 5 DE AGOSTO DE 2005

Dispðe sobre o ensino da lingua espanhola.

O PRESIDENTE DA REPÚBLXCA Faç saber que o Congresso Nacional decreta e eu sancion a seguintc Lei:

Art. ja 0 ensino da língus espanhola, de oferta obrigatóri pela escola e de matrfcula facultativa para o aluno, serí implantado, pela escola e de mats/cura facultativa para o aluno, será
gradativamente, nos curiculos plenos do ensino medio.

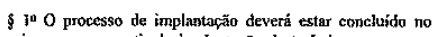
prazo de cinco anos, a partir da implantaç̧o slesta Lei.

$\S 2^{\circ}$ É facultada a inclusāo da lingun espantola nos curriculos plenos do ensino fird

Art. $2^{2} \mathrm{~A}$ oferta da língua espanhola pelas redes públicas de ensino deverá ser feitn no horário regular de aula dos alunos.

An. $3^{2}$ Os sistemas públitos de ensino implantarão Centros de Ensino de Lingua Estrangeira, cuja programaçăo incluirá, neces
sariameste, a offra de lngua espanhola.

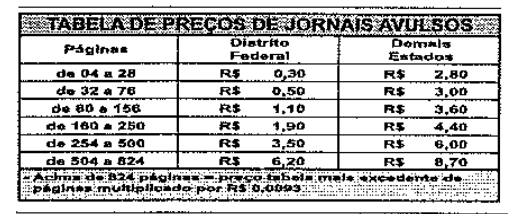

Art 49 A rede privada poderá tornar disponivel esta oferla
por meio de diferentes estrattegias que incluam desde aulas conpor meio de diferentes estrategias que incluan desde aulas conCentro de Estudos de Líggua Moderna.

Art. $5 \mathrm{a}$ Os Consellhos Estaduais de Educaçăo e do Distrito

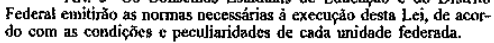
Art, $6^{\mu} \mathrm{A}$ Uniāo, no àmbito da politica sacional de educação,
estimutará $\mathrm{e}$ apoiará os sistemas estaduais e do Distrito Federal na estimulará e apoiará os sisternas estaduais e do Distrito Federal

Art $7^{2}$ Esta Lei entra en vigor na data da sua pubbicaçắo. da Repüblica.

Braslfix, $S$ de agosto de 2005; $184^{\circ}$ da Inúcpendéncia e $117^{\circ}$ LUIZ INÁCIO LULA DA SILVA

LEI N" 11.162, DE 5 DE AGOSTO DE 2005 Institui o Dia Nacional da Assistência Social. O PRESIDENTE DA REPÚBLICA a seguime Lei:

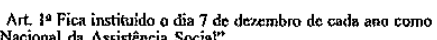

Ar. $2^{2}$ Esta Lei entra em vigor na data de sua publicaçío. Brasilia, 5 de agosto de 2005; 184" dã Independência e 117

\section{LUZZ INÁCIO LULA DA SLEVA} Potrus Anamias
Gilterto Gil

\section{Atos do Poder Executivo}

DECRE'TO N= 5.504, DE 5 DE AGOSTO DE 2005

Estabelece a exięnncix de utilizaça do pro-

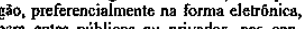
para cates péblicos ou privados, nas con-
trataçes de bens $\mathrm{e}$ serviços comuns, realizadas $\mathrm{cm}$ deconéncia de transfcréncias voluntárias de recursos públicos da Unizito, decomentes de convênios ou insin
conténeres, ou consórcios públicos.

O PRESIDENTE DA REPÚBLICA, no uso da atribuiçăo que the confere o art. 84, inciso VI, allnea " $\mathrm{a}^{n}$, e tendo em vista o

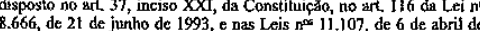
2005, e 10.520, de 17 de juluo de 2002,

D E C R E T A :

Att $1^{n} O s$ instrumentos de formalizą̧̃̃a, renovação ou ad tamento de convênios, instrumentos congêneres ou de consórcios pa.

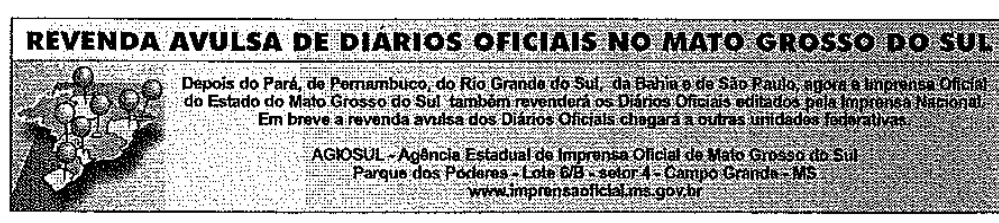

deveräo conter ctáusula gue deternine que as obras, compras, seton sejan contratadas mediante processo de ficitaçăo púbtica, de acordo com o estabelecido na legislaçăo federat pertinente.

5 la Nas licitaçđes realizadas com a utilização de recursos epassndos nos termos do caput, para aquisiçăa de bens e servicos comuns, será obrigatório o emprego da modalidade pregão, nos termos da Lei $n^{2}$ ti.szo, de 17 de jullio de 2002 , e do regulamento previsto no Decreto na $n^{2} .450$, de 31 de maío de 2005 , sendo pro nograma a ser definido em instruç̄u complementar.

$2^{2}$ A inviabilidade da utilizuçāo do pregào na forma elo trônica deverá ser devidamente justificada pelo dirigense on auto-

$\$ 30$ Os Grgăos, entes e entidades privadas sem fins lu-

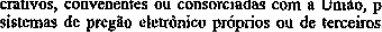

$\S 4^{0}$ Nas situaçôes de dispensa ou inexigibilidnde de liratificą̧ão ser procedida pela instância máxima de declibcraç̧̃ó entidade, sob pena de nulidade.

$\$ 5^{n}$ Aplica-se o disposto nestc artigo is entidades qua-
como Organizaçes Sociais, na forma da Lei na 9.637 , de is

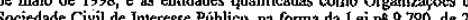
de marco de 1999, relativamente aos recursos por elas adminisurados oriundos de repasses da Unizo, em face dos respectivos contraltos de gestäo ou termos de parceria.

Art, $2^{\circ}$ Os órgąos, enless e instituiç̄es convenentes, firmatários de contrato de gestào ou termo de parceria ou consorciziados

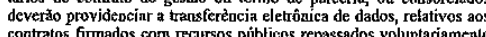
peja Uniäo paras o Sistema Integraalo de Adrinistraçẵo de Serviços

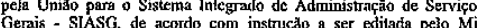
nistério do Planejamento, Osçamento e Gestín.

Art. $3^{n}$ As transfereenecias voluntárias de recursos públicos th apresentaçäo, pelos convenenles ou consorciados, da documentaçäa

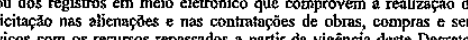

Art 40 Os Ministérios do Planejamento, Orçamento e Gestío - ar

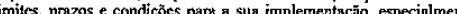

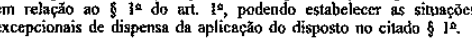

Art. $5^{\circ}$ Este Decreto entra emn vigor na data de sua publicaçăho. Brasilia, 5 de agosto de 2005; 184" da Independência $c: 17$ LUHZ INÁCIO LULAA DA SILVA Antonio Palacci Filho 


\section{ANEXO B - PL No 3.987/2000 - Deputado Átila Lira}

PROJETO DE LEI No 3.987, DE 2000

(DO SR. ÁTILA LIRA)

Dispõe sobre o ensino da língua espanhola.

(ÀS COMISSÕES DE EDUCAÇÃO, CULTURA E DESPORTO; E DE CONSTITUIÇÃO E JUSTIÇA E DA REDAÇÃO (ART. 54) - ART. 24 II)

O Congresso Nacional decreta:

Art. $1^{\circ} \mathrm{O}$ ensino da língua espanhola, de oferta obrigatória pela escola e de matrícula facultativa para o aluno, será implantado, gradativamente, nos currículos plenos do ensino médio.

$\S 1^{0} \mathrm{O}$ processo de implantação deverá estar concluído no prazo de cinco anos, a partir da implantação desta Lei.

$\S 2^{\mathrm{o}}$ É facultada a inclusão da língua espanhola nos currículos plenos do ensino fundamental de $5^{\mathrm{a}}$ a $8^{\mathrm{a}}$ séries.

Art. $2^{\underline{0}} \mathrm{~A}$ oferta da língua espanhola pelas redes públicas de ensino deverá ser feita no horário regular de aula dos alunos.

Art. $3^{\circ}$ Os sistemas públicos de ensino implantarão Centros de Ensino de Língua Estrangeira, cuja programação incluirá, necessariamente, a oferta de língua espanhola.

Art. $4^{\circ} \mathrm{A}$ rede privada poderá tornar disponível esta oferta por meio de diferentes estratégias que incluam desde aulas convencionais no horário normal dos alunos até a matrícula em cursos e Centro de Estudos de Língua Moderna.

Art. 5ํㅡㄹ Os Conselhos Estaduais de Educação e do Distrito Federal emitirão as normas necessárias à execução desta Lei, de acordo com as condições e peculiaridades de cada unidade federada.

Art. $6^{-}$A União, no âmbito da política nacional de educação, estimulará e apoiará os sistemas estaduais e do Distrito Federal na execução desta Lei.

Art. $7^{0}$ Esta Lei entra em vigor na data da sua publicação. 


\section{ANEXO C - JUSTIFICAÇÃO PL N 3.987/2000}

\section{JUSTIFICAÇÃO}

A importância da língua espanhola, hoje, no contexto mundial é indiscutível. Mais de 400 milhões de pessoas se comunicam nessa língua. Certamente a grande expansão do poder hispânico nos séculos XVI e XVII permitiram a difusão da cultura da metrópole nas colônias e as consequentes conquistas fixaram a língua como marca da ocupação.

A maioria esmagadora dos países que integram a América Latina é composta por nações hispânicas, que por conseguinte falam o idioma espanhol. O Brasil, onde se fala apenas o português, tornou-se uma ilha, neste contexto. Com a consolidação do Mercosul, aumenta a necessidade de se conhecer a língua espanhola, que já ocupa o segundo lugar como elemento de comunicação do comércio internacional.

A preocupação, por parte das autoridades educacionais brasileiras, com o ensino da língua espanhola, reporta-se ao Decreto-lei no 4.244 de 9 de abril de 1942 que obrigava o estudo do idioma espanhol como disciplina constitutiva dos cursos clássico e cientifico.

Com o advento da Lei $\mathrm{n}^{\circ} 4.024$ de 20 de dezembro de 1961, Lei de Diretrizes e Bases da Educação Nacional, a grande maioria dos estabelecimentos de ensino no Brasil eliminou, de seus currículos, o estudo do idioma espanhol.

A seguir, a Lei $\mathrm{n}^{\circ}$ 5.692, de 11 de agosto de 1971, que fixou Diretrizes e Bases para o ensino de $1^{\circ}$ e $2^{\circ}$ grau, o currículo mínimo, a ser exigido em cada habilitação profissional ou conjunto de habilitações afins, havendo sido sistematicamente desprezado o estudo do idioma espanhol.

Com a promulgação da Constituição Brasileira de 1988, que dispõe em seu art. $4^{\circ}$ que:

\section{“A República Federativa do Brasil buscará a integração econômica, política, social e} cultural dos povos da América Latina, visando à formação de uma comunidade latinoamericana de nações", reforçou-se o conhecimento da língua espanhola, pois a integração passa pela compreensão recíproca, e abriu-se a possibilidade de acordos bilaterais no ensino de idiomas.

Posteriormente, o advento da Lei de Diretrizes e Bases, Lei $\mathrm{n}^{\circ}$ 9.394, de 20 de dezembro de 1996, após longo período de negociações com a participação da sociedade civil, concluiu que a educação básica, nos níveis fundamental e médio, teria regras comuns que "poderão organizar-se em classes, ou turmas, com alunos de séries distintas, com níveis 
equivalentes de adiantamento na matéria, para o ensino de línguas estrangeiras, artes, ou outros componentes curriculares". E no art. $26, \S 5^{\circ}$ determina: "Na parte diversificada do currículo será incluído, obrigatoriamente, a partir da quinta série, o ensino de pelo menos uma língua estrangeira moderna, cuja escolha ficará a cargo da comunidade escolar, dentro das possibilidades da instituição". Na seção IV, do Ensino Médio, art. 36, III, completa: "será incluída uma língua estrangeira moderna, como disciplina obrigatória, escolhida pela comunidade escolar, e uma segunda, em caráter optativo, dentro das possibilidades da instituição".

A abertura para o ensino de línguas estrangeiras preconizada pela LDB demonstra a necessidade da inclusão no currículo, a importância do aprendizado, e a valorização da escolha da língua por parte da comunidade onde a escola está inserida.

Particularmente, destacamos a língua espanhola, pela relativa facilidade de compreensão, pela aproximação geográfica com os países latino-americanos, pelo elevado número de publicações seja na língua vernácula ou em traduções de outros idiomas e pela ampliação de oportunidades na comunicação global.

Inúmeros projetos tramitaram nesta Casa com o mesmo objetivo que ora propomos. Muitos foram arquivados e outros, prejudicados. Um, especialmente, apresentado em 1993 por iniciativa do Poder Executivo, deveria também ter sido prejudicado, pois trazia proposta que contrariava o espírito aberto da LDB. Por uma imperiosa situação regimental continua em tramitação não podendo ser emendado.

Diante desta situação apresento uma nova proposta que engloba as anteriores, traz a ideia do Centro de Línguas, como alternativa inovadora, e obriga as escolas a oferecerem o aprendizado da língua espanhola, deixando liberdade de escolha aos alunos para esta língua ou outra de interesse pessoal.

Espero que os nobres Pares apoiem a minha iniciativa que procura sanar uma lacuna regimental. E cientes da importância da língua espanhola para a integração cultural, econômica e social do Brasil com os demais países [hispânicos] unam-se pela urgência de aprovação deste projeto.

Sala de Sessões, em [15] e [dezembro] de 2000. 
ANEXO D - LEI No 3.694/2005

\section{LEI N 3.694, DE 8 DE NOVEMBRO DE 2005}

(Autoria do Projeto: Deputado Paulo Tadeu)

\section{Regulamenta 0 § $1^{\circ}$ do art. 235 da Lei Orgânica do Distrito Federal quanto à oferta de ensino da língua espanhola aos alunos da rede pública do Distrito Federal.}

O Presidente da Câmara Legislativa do Distrito Federal promulga, nos termos do $\S 6^{\circ}$ do art. 74 da Lei Orgânica do Distrito Federal, a seguinte Lei, oriunda de Projeto vetado pelo Governador do Distrito Federal e mantido pela Câmara Legislativa do Distrito Federal:

Art. $1^{\circ}$ Os estabelecimentos de ensino integrantes do sistema de ensino do Distrito Federal são obrigados a oferecer a disciplina de língua espanhola como opção de língua estrangeira para os alunos do ensino fundamental e médio.

Parágrafo único. A oferta de ensino da língua espanhola será implantada progressivamente a partir da $1^{\mathrm{a}}$ série do ensino médio e, em seguida, a partir da $5^{\mathrm{a}}$ série do ensino fundamental.

Art. $2^{\circ}$ Esta Lei entra em vigor na data de sua publicação.

Art. $3^{\circ}$ Revogam-se as disposições em contrário.

Brasília, 10 de novembro de 2005.

\section{DEPUTADO FÁBIO BARCELLOS}

Presidente

Este texto não substitui o publicado no Diário Oficial do Distrito Federal, de 24/11/2005. 
ANEXO E - PL No 4.606/1958

\title{
Projeto n. 4.606 de 1958
}

\author{
Altera o Dec.-lei no 4.244 de \\ 9 de abril de 1942 no que se refere \\ Ao aprendizado do idioma espanhol \\ Nos dois ciclos do ensino secundário
}

(Do Poder Executivo)

(Às comissões de Constituição a Justiça do Serviço Público e de Finanças)

O congresso Nacional decreta:

Art. $1^{\circ} \mathrm{O}$ idioma espanhol será ministrado nos dois ciclos do ensino secundário observadas as mesmas bases estabelecidas no Decreto-lei número 4.244 de 9 de abril de 1942 para o ensino do idioma inglês, inclusive no que tange às séries e cursos em que será lecionado.

Art. $2^{\circ}$ Esta lei entrará em vigor na data de sua publicação, revogadas as disposições em contrário, 


\title{
ANEXO F - EXPOSIÇÃO DE MOTIVOS No 745/1958
}

\author{
EXPOSIÇÃO DE MOTIVOS N 745, DE 1958 DO \\ MINISTÉRIO DA EDUCAÇÃO E CULTURA
}

Em 16 de setembro de 1958

Excelentíssimo Senhor Presidente da República;

A revisão da Política Continental em que se empenha o Govêrno, com o propósito de dar novos rumos ao pan-americanismo, recomenda a adoção de medidas no setor da educação, que possam contribuir para seu êxito.

Estre essas medidas, está a inclusão do ensino de Espanhol como disciplina obrigatória no ensino secundário idioma da maioria dos países americanos, cujo conhecimento, pela juventude brasileira, constituirá mais um liame com os povos do continente.

A atual Lei Orgânica do Ensino Secundário já prevê, é verdade, o ensino do Espanhol, mas com a duração de, apenas, um ano, e como disciplina do segundo ciclo, salientando as instruções metodológicas baixadas para a execução do programa que, entre as finalidades do ensino do Espanhol, está a de "mostrar-lhe a origem românica como a do Português que tem a língua de Castela e da maioria dos países americanos, o que ajudará a compreender os sentimentos pan-americanos".

O maior estreitamento dos povos do continente americano reclama, no entanto, um estudo mais intenso do idioma espanhol no curso secundário e a sua inclusão como disciplina obrigatória no primeiro ciclo, a fim de ser dada maior difusão ao ensino e tomar possível a plena consecução dos seus objetivos.

Estando em tramitação no Senado Federal o projeto de lei da Câmara no 338 de 1958, que dá novo texto à Lei Orgânica do Ensino Secundário, seria oportuna essa iniciativa mediante emenda que poderia ser apresentada ao plenário daquela Casa do Congresso Nacional.

O Ministério da Educação e Cultura, quando se manifestou sobre o referido projeto, em julho de 1957, tendo em vista o seu propósito de simplificação do currículo, não fêz incluir o ensino do Espanhol, mas o substitutivo aprovado pela douta Comissão de Educação e Cultura do Senado Federal incluiu esse idioma como disciplina complementar do curso ginasial e dos cursos clássico e científico (item II art. 10).

Agora, no entanto, tendo em vista os novos rumos da política continental, o Ministério da Educação e Cultura julgaria recomendável a inclusão do ensino de Espanhol como disciplina obrigatória do $1^{\circ}$ ciclo do curso secundário ampliando a iniciativa do ilustre Senador Domingos Velasco, consubstanciada na emenda que ofereceu, tornando o idioma Espanhol disciplina estrutural do $2^{\circ}$ ciclo, em paridade com o Francês e o Inglês.

Apresentando essas considerações para as providências que forem julgadas cabíveis renovo a Vossa Excelência os protestos do meu profundo respeito. - Clóvis Salgado. 


\section{ANEXO G - MENSAGEM Nº 337/1958}

\section{MENSAGEM N 337-58 DO PODER EXECUTIVO}

Excelentíssimos Senhores Membros do Congresso Nacional:

$\mathrm{Na}$ forma do art. 67 da Constituição, tenho a honra de submeter à apreciação de Vossas Excelências acompanhado de Exposição de Motivos do Ministro de Estado da Educação e Cultura, o incluso projeto de lei, alterando o Decreto-lei no 4.244 , de 9 de abril de 1952, no que se refere ao aprendizado do idioma espanhol nos ciclos do ensino secundário.

A equiparação do ensino do idioma espanhol ao inglês nas diversas séries e cursos do ensino secundário tal como prescreve o projeto anexo, impõem-se como corolário dos novos rumos dados ao pan-americanismo, em consequência da política adotada pelo Govêrno, eis que se trata do idioma falado pela maioria dos povos americanos.

Em verdade, é uma resultante inafastável das amplas perspectivas que se abriram ao entrelaçamento das relações pan-americanas, através da atual política continental, de mais íntima aproximação dos países deste hemisfério.

Rio de Janeiro, em 22 de setembro de 1958. - Juscelino Kubitschek. 


\section{ANEXO H - EXERCÍCIO (1ª OBSERVAÇÃO - TAGUATINGA)}

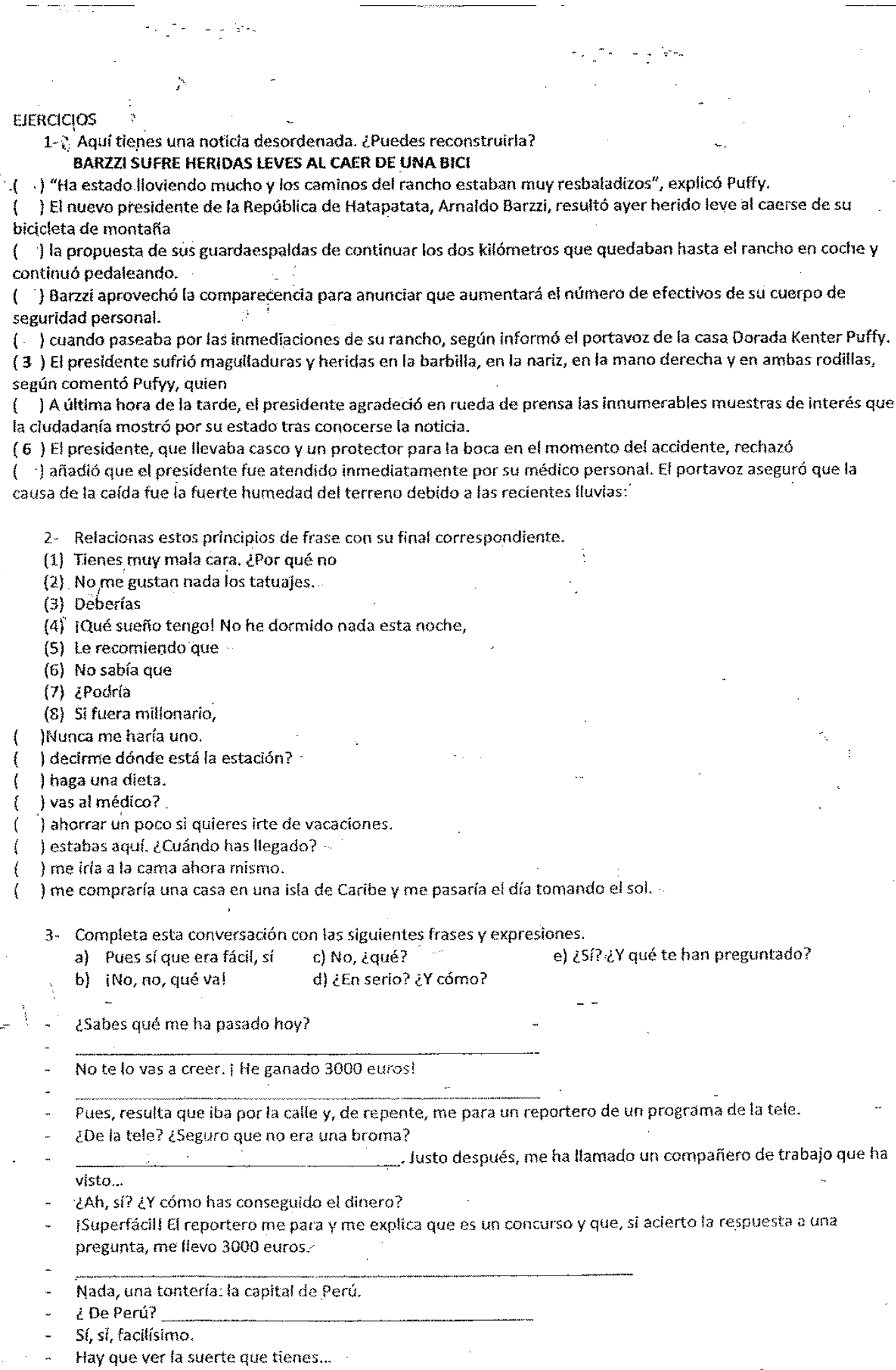

( I Aúltima hora de fa tarde, el presidente agradeció en rueda de prensa las innumerables muestras de interés que la cludadanía mostró por su estado tras conocerse la noticia.

(6) El presidente, que llevaba casco y un protector para la boca en el momento del accidente, rechazó

( ) añadió que el presidente fue atendido inmediatamente por su médico personal. El portavoz aseguró que la causa de la caida fue la fuerte humedad del terreno debido a las recientes lluvias:

2- Relacionas estos principios de frase con su final correspondiente.

(1) Tienes muy mala cara. LPor qué no

(2) No me gustan nada los tatuajes.

(3) Deberías

(4) IQué sueño tengol No he dormido nada esta noche,

(5) Le recomiendo que

(6) No sabía que

(7) ZPoctria

(8) Si fuera millonario,

Nunca me haría uno.

I decirme dónde está la estación?

( ) haga una dieta.

( vas al médico?

( ) ahorrar un poco si quieres irte de vacaciones.

( ) estabas aquí. ¿Cuándo has llegado?

( ) me iria a la cama ahora mismo.

I me compraría una casa en una isla de Caribe y me pasaría el día tomando el sol.

3- Compteta esta conversación con las siguientes frases y expresiones.
a) Pues sí que era fácil, si
c) No, ¿qué?
b) iNo, no, qué va!
d) ¿En serio? ¿Y cómo?
e) ¿5f? ¿Y qué te han preguntado?

-

¿Sabes qué me ha pasado hoy?

No te to vas a creer. I He ganado 3000 eturos!

Pues, resulta que iba por la calle y, de repente, me para un repartero de un programa de la tele. ¿De la tele? ¿Seguro que no era una broma? . Justo después, me ha llamado un compañero de trabajo que ha visto..

- ¿Ah, si? ¿Y cómo has conseguido el dinero?

- iSuperfácll El reportero me para y me explica que es un concurso y que, si acierto la respuesta a una pregunta, me flevo 3000 euros.

Nada, una tontería: la capital de Perú.

¿ De Perú?

Si, sli, facilísimo.

Hay que ver la suerte que tienes... 
Comprensión auditiva I

Alumnos:

no:

no:

Grupo:

Escucha el texto "Orígenes del deporte" y juzga las afirmaciones de acuerdo con el código:

(1) Para las verdaderas

(2) Para las falsas

a. ( La fantasía del hombre y su profunda capacidad simbólica han contribuido a que la necesidad de sobrevivencia haya evolucionado a lo social y a lo económico.

b. ( ) Para los expertos, los deportes parecen haber tenido su nacimiento como leyendas o quizá como el instinto de sobrevivencia.

c. ( ) Otros deportes, como el patinar sobre nieve, estarían vinculados con el sostenimiento de las leyes.

d. ( ) Cuando un jugador hace un gol, sus compañeros corren hacia él, to tocan como si el cuerpo de él tuviese algo mágico.

e. ( ) Es un rasgo común a los deportes el placer derivado de la demostración de poder, de mejora constante $y$ de superación.

f. ( ) Algunos deportes estarian vinculados a las guerras o contiendas que periódicamente se suscitaban entre los pueblos de la antigüedad.

g. ( ) Durante los períodos de infancia y la juventud, miembros de pueblos del mundo, tienen juegos particulares.

h. ( ) El salto en alto o en largo, la lucha cuerpo a cuerpo, el correr son ejemplos claros que los deportes están relacionados directamente con algunos rituales sagrados antiguos.

i. () Muchos deportistas de la antigüedad pertenecían a un ámbito sagrado.

j. ( ) Según el autor, ya no existe en las prácticas deportivas actuales la conexión con lo sagrado. 


\section{ANEXO J - EXERCÍCIO PROFISSÕES (5a OBSERVAÇÃO - TAGUATINGA)}

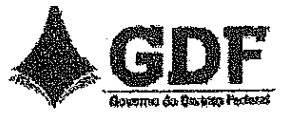

Alumgno (a):

Clase:

\section{Ejercicios - Profesiones}

2. De acuerdo con las pistas, trata de poner la profesión en su sitio correcto:

1. Sirve mesas y trabaja en bares y restaurantes.

2. Deflende a personas acusadas.

3. Trabaja en la iglesia. Realiza casamientos y bautismos.

4. Trabaja con madera, serrucho y clavos. Hace casas.

5. Trabaja en avión, culdando a que no les falte nada a los pasajeros durante los vuelos.

6. Prepara los alimentos que comemos.

7. Trabaja con lámparas, enchufes y cables. Es el responsable por la iluminación de casas y edificios.

8. Vende la carne que consumimos.

9. Construye casas y edificios con arena, cemento, piedras y ladrillos.

10. Es el responsable por la instalación hidráulica de las viviendas. Su especialidad son las cañerías y los grifos/canillas.

11. Corta, lava, tiñe y peina el pelo de las personas.

12. Trabaja con tinta, pincel y brocha para dar más color a la ciudad.

13. Registra por medio de imágenes los acontecimientos en general.

14. cuida de la salud de los animales.

15. Trabaja en casas muy finas, sirviendo a sus patrones.

16. Arregla utiles hechos de cuero, como cinturones, bolsos y zapatos.

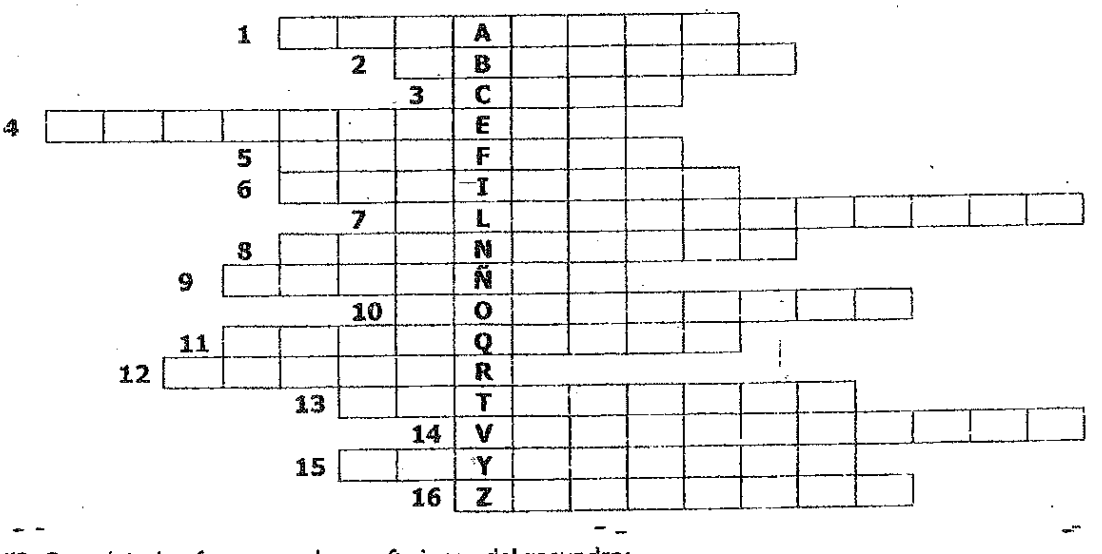

1. Completa las frases con las profesiones del recuadro:

$$
\text { cantante profesora conductor dependienta panadero policía }
$$
arquitecto cartero niñera taxista enfermera
a) La
vende zapatos o ropa, o fruta...
b) La atienda a los enfermos
c) $\mathrm{El} \ldots$ lleva las cartas a las casas.
Ch) La i canta.
d) $\mathrm{El} \ldots$ detiene al ladrón.
e) El ___ ll__ ll_ l_ a los pasajeros en su coche.
f) $\mathrm{EI} \ldots$ conduce coches y camiones.
g) El _._._. proyecta casas y edificios.
h) La ___ trabaja en una escuela
i) $\mathrm{El} \ldots$ hace panes y pasteles.
j) La cuida de los bebés. 


\section{ANEXO K - EXERCÍCIO AVALIATIVO (4 OBSERVAÇÃO - PARANOÁ)}

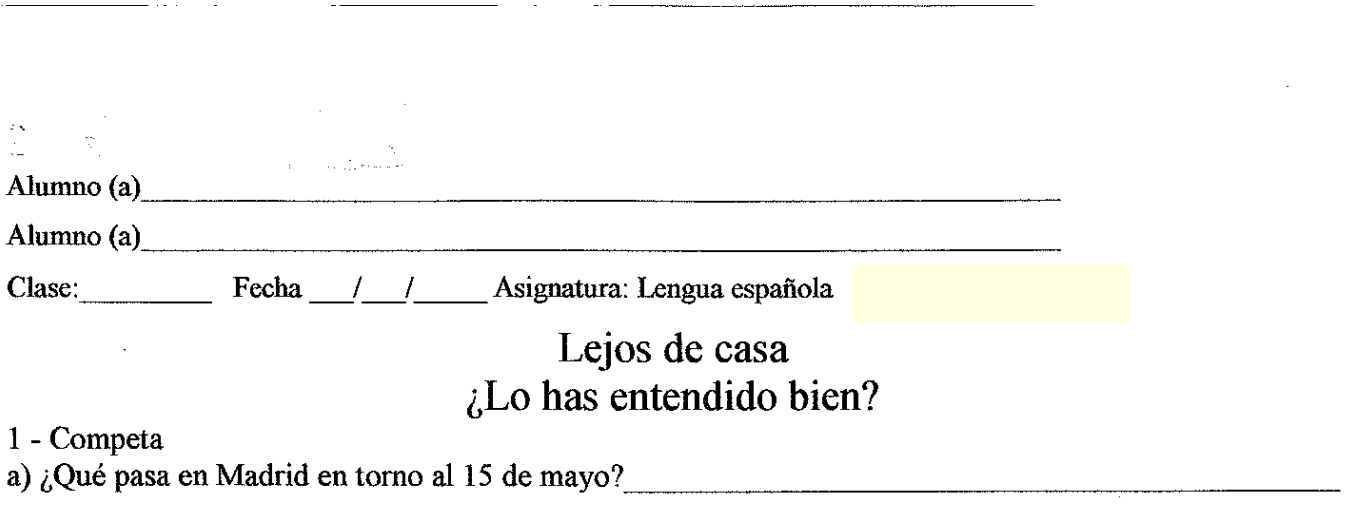

b) ¿Le gustan a Lola las fiestas populares? ¿Qué planes tenía ese año para San Isidro?

c) ¿Qué pasó en la oficina ese 12 de mayo?

d) Quien es Maria José Sancho? ¿Qué quería?

2 - Completa las frases

a) María José Sancho parece

b) Físicamente es

c) Piñalbina es

d) En la asociación de vecinos del barrio, algunos voluntarios

4 - ¿Puedes relacionar estas informaciones con cada personaje?
A - Lola B - Laura

( ) Lo estaba pasando mal

( ) Quería ayudarla

( ) Preguntó a un camarero

( ) Le pidió ayuda

( ) Sus padres no querían que saliera con un extranjero

( ) Sabía dónde estaba Humberto

( ) La tranquilizó

11, 12 y 13 - Di si son verdad o mentira las informaciones siguientes.

1. ( ) La prima de Miguel se llama Elisenda.

2. ( ) El jetas tiene una moto nueva.

3. ( ) Andrés sabe que Humberto es inocente.

4. ( ) La habitación del tigre estaba vigilada.

5. ( ) El "Tigre" puede hablar.

7. ( ) Humberto atacó al "Tígre".

9. ( ) El inspector Gil no se cree lo que dice Lola.

6. ( ) El "Tigre" puede comunicarse con Lola

8. ( ) El inspector Gil es muy simpático.

10. ( ) Para la policía el culpable es Humberto.

Relaciona.
a. El permiso de residencia
( ) es un gran parque madrileño.
b. El 12 de octubre
( ) es el documento oficial que permite que alguien viva en España.
c. El parque de San Isidro
( ) es uno de los grandes hospitales de la Seguridad Social de Madrid.
d. El cocido madrileño
( ) es el plato más típico de la cocina madrileña. 


\section{ANEXO L - EXERCÍCIO IMPERATIVO (5 OBSERVAÇÃO - PARANOÁ)}

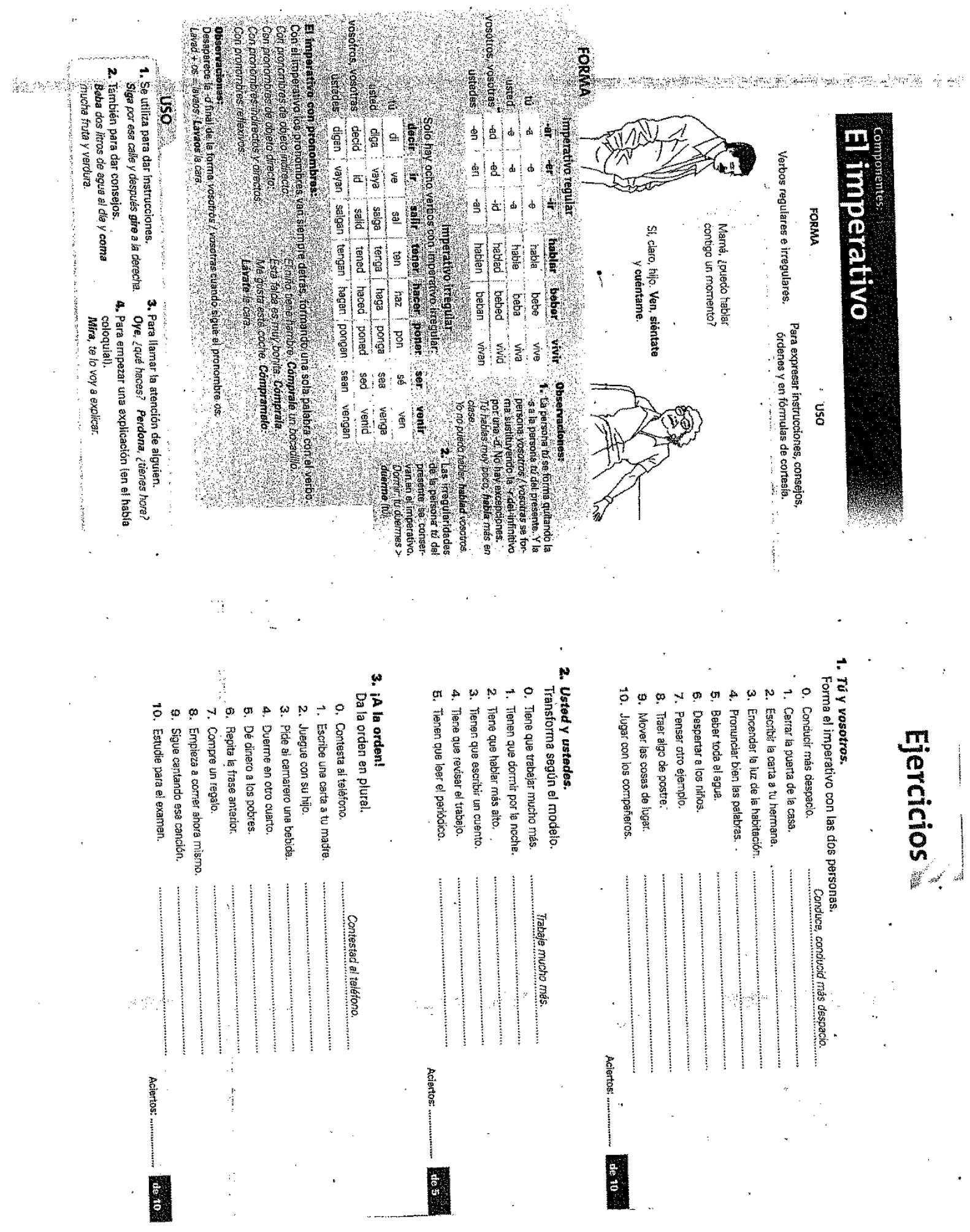



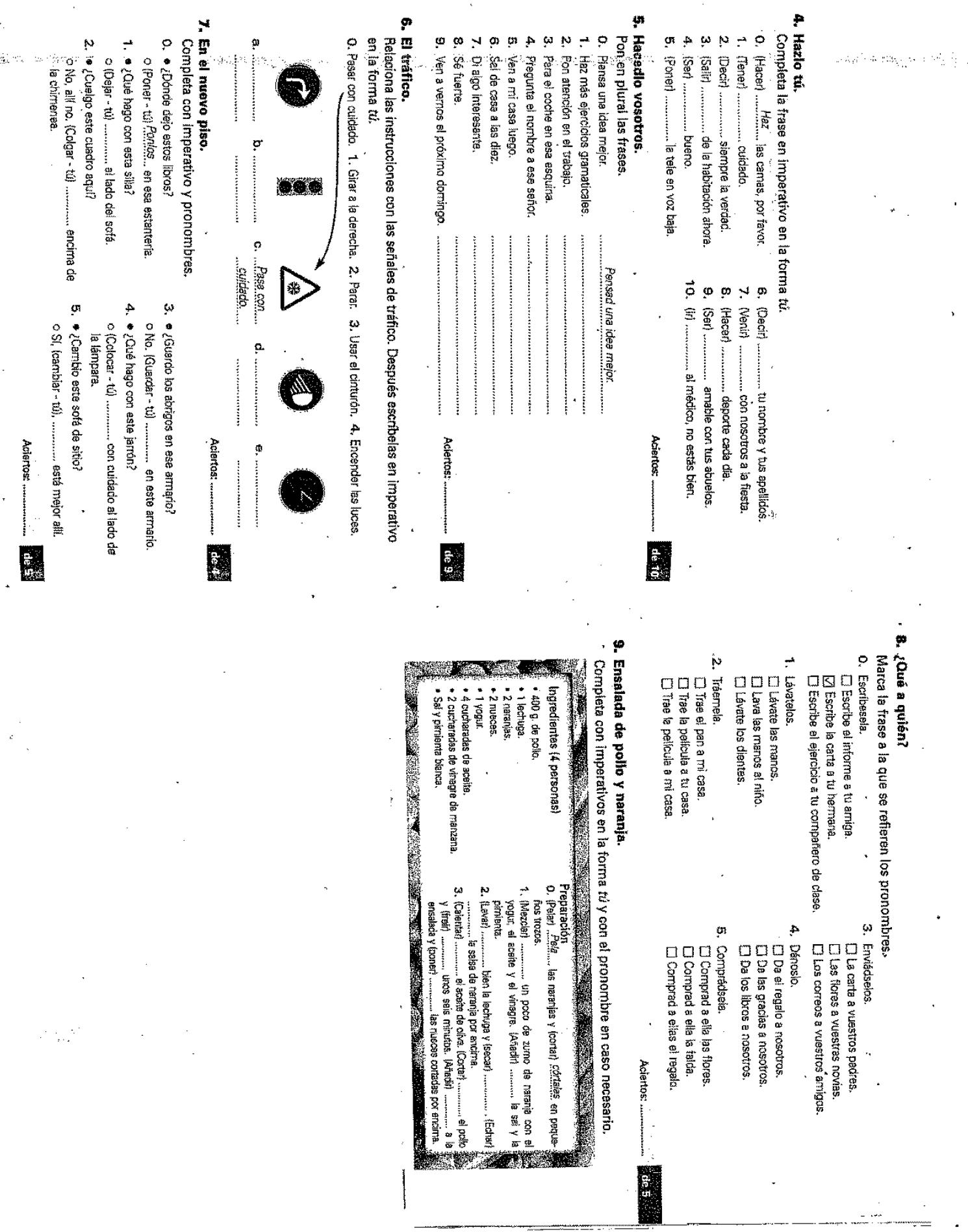


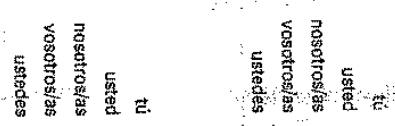

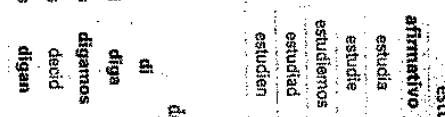

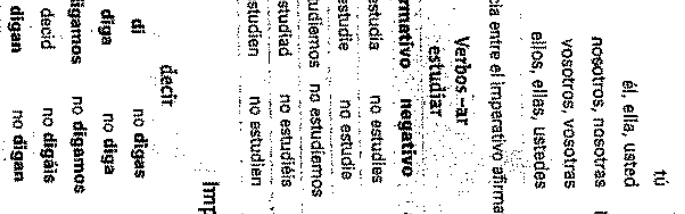

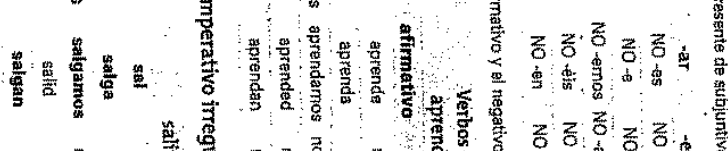

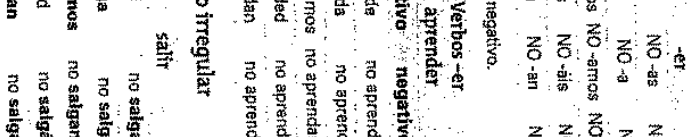

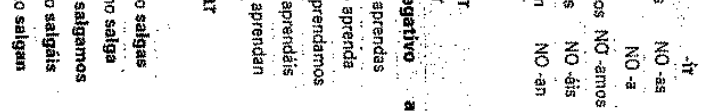

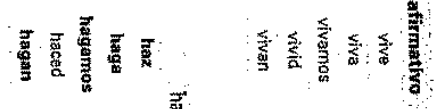

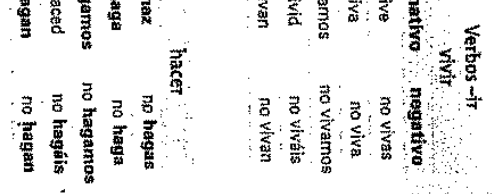
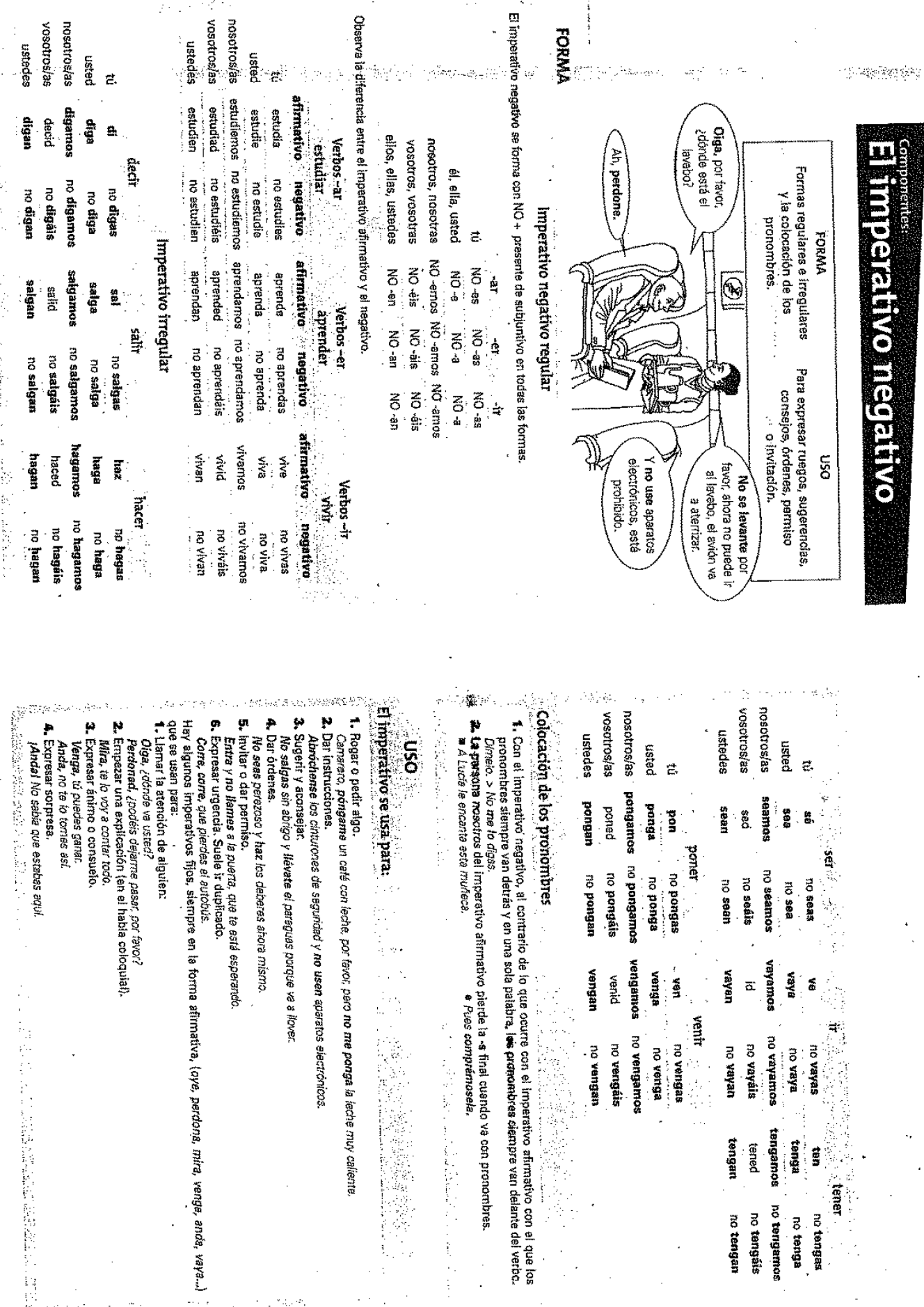


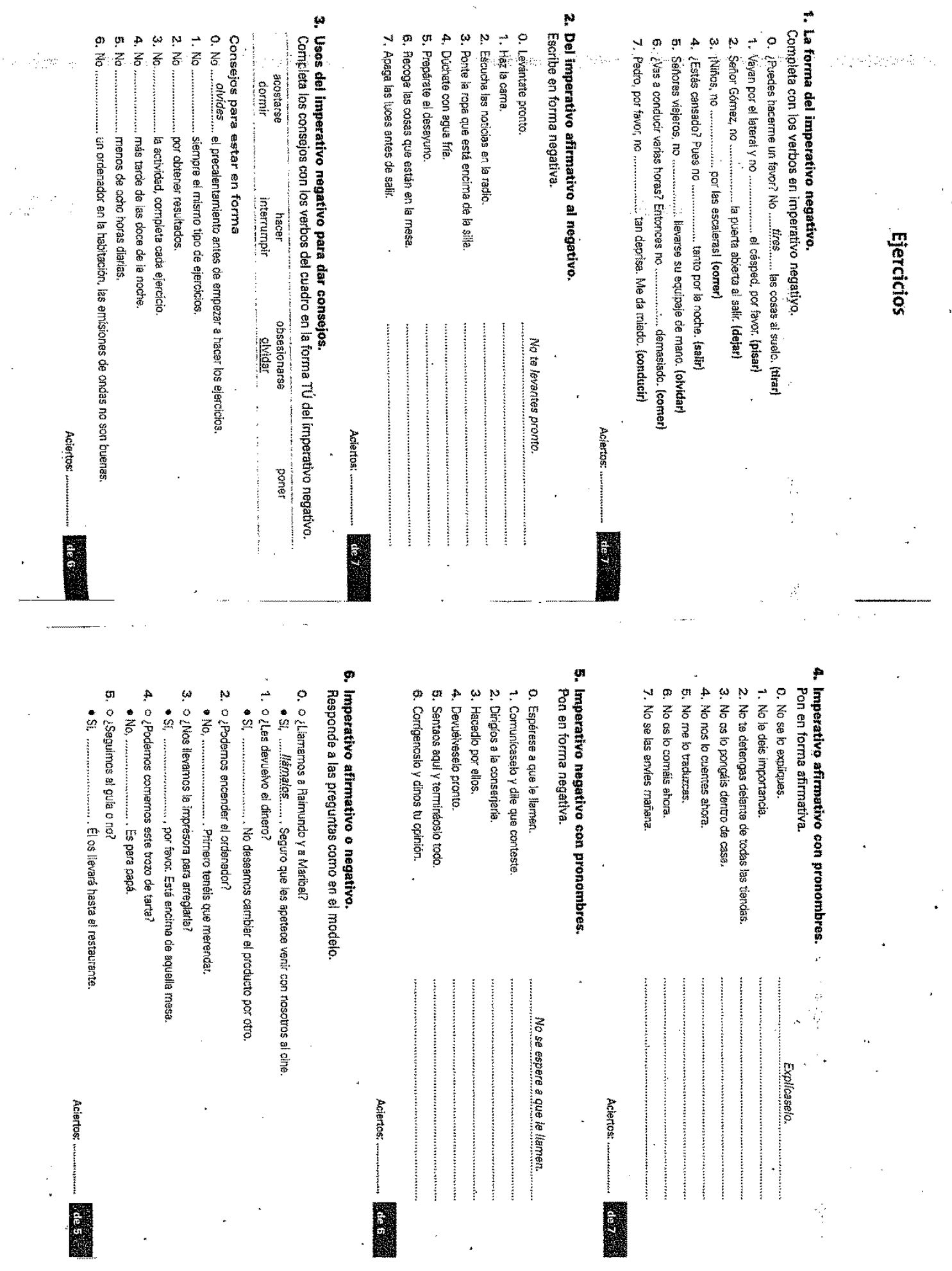




\section{ANEXO N - PROVA DE ESPANHOL, VESTIBULAR UNB 2006 (7 OBSERVAÇÃO - PARANOÁ)}

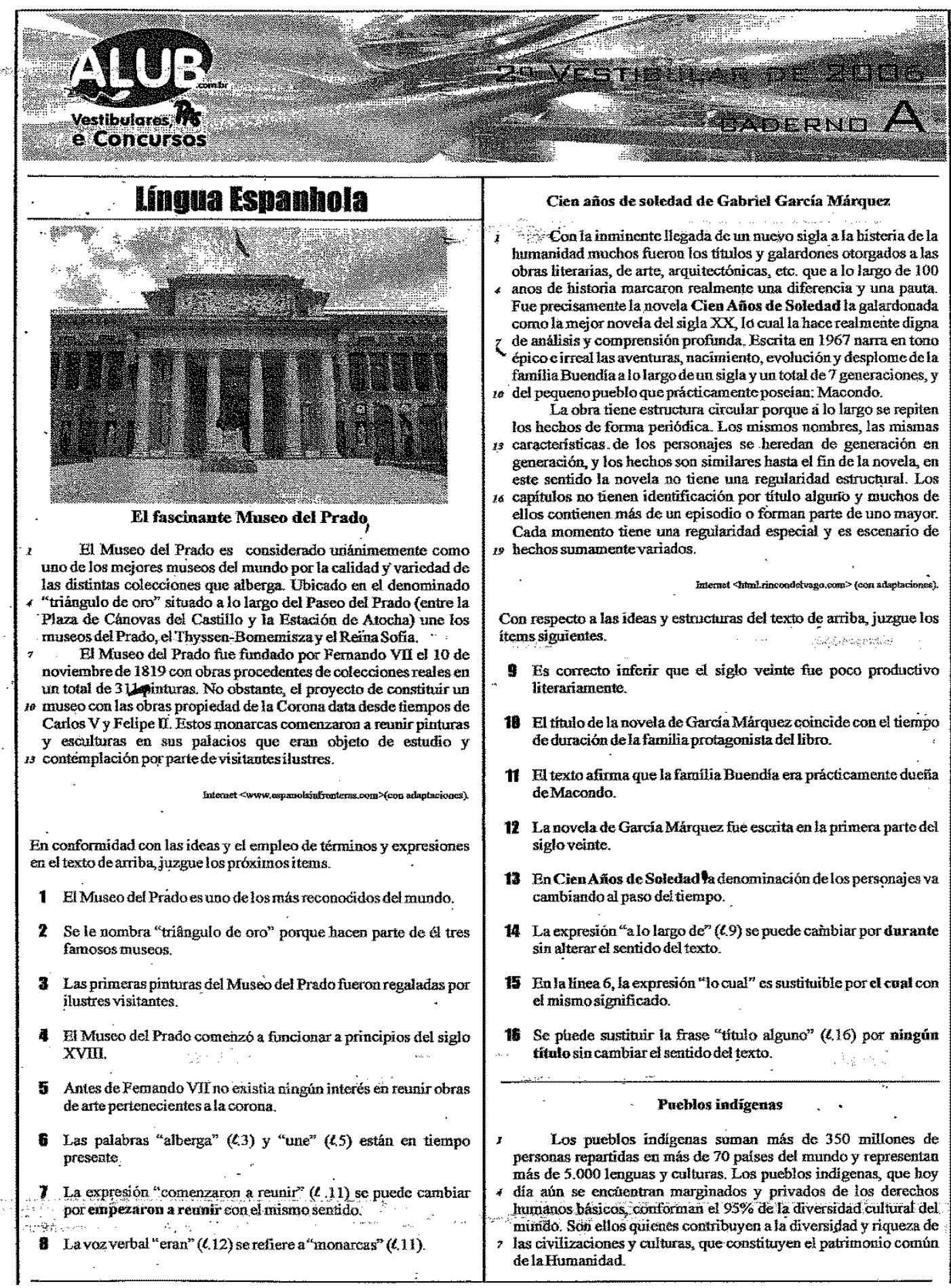


En la región Latinoamérica viven más de 40 millones de to jndigenas Existen países en los que lãs poblacionen indígenas constituyen la mayoría de la población. Así ocure en Bolivia $(63 \%)$, en Guatemala, donde representa más de la mitad de la 13 población, o en Ecuador y Peru, donde supone cerca del $45 \%$. Por su parte, en México vive una importante y múltiple comunidad indígena, que en términos porcentuales es sólo del $10 \%$ de la 16 población pero que, en términos totales suma más de 10 millones de personas.

Con relación a las ideas y términos del texto juzgue lašítems siguientes.

I Una riqueza de las culturas indígenas es la diversidad.

18 Los indigenas siguen sin tener sus derechos humanos básicos respetados.

19 La mayor parte de la población indigena del mundo vive en la región Latinoamérica.

20 Hay países en Sudamérica en que la población indígena sobrepasa a las demás etnias.

21 La expresión "se encuentran marginados" (८.4) significa que viveu en la arilla de los nios.

22 Lapalabra “contribuyen" (¿.6) está en fiempo pasado.'

23 En la línea 9, las elementos "región" y "más" llevan tildè por el mismo motivo.

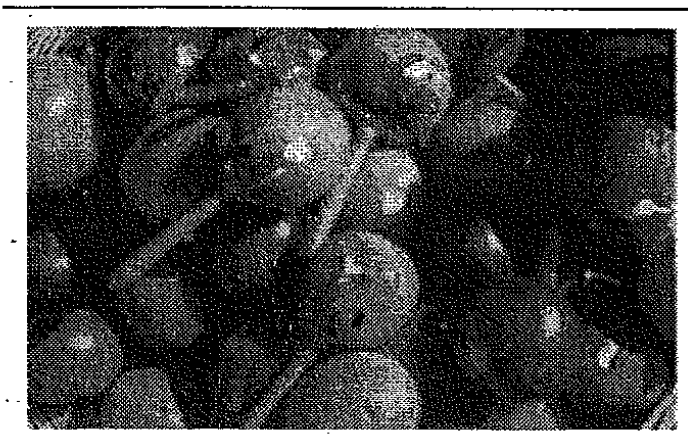

Riquexa de la música latinoamericana

Según Sancho Panza, "Donde hay música no puede haber cosa mala" (Quijote 2.4.34). Aunque existen canciones en todas partes del globo, las de Latinoamérica tienen una variedad y riqueza sin par. Los latinoameriçanos representan una porción importante de la población mundial que se carạcteriza por su diversidad idiomática y cultural. Desde canciones folclóricas cuyos origenes se han perdido en un pasado remoto hasta el último disco de un artista de la actualidad, la música latinoamericana abarca una gama temporal amplia. Geográfica, étnica, y lingüísticamente hablando, las canciones de Latinoamérica son variadísimas. En tiempos en que no existia radio, cine, o televisión, y ien poblaciones en que era común un porcentaje alto de analfabetos, las canciones en algunas oportunidades hicieron el papel que los medios de comunicación hacen hoy en dia. La letra de cada canción, como cualquier creación literaria, es un artefacto linguístico surgido dentro de un contexto histórico-artístico específico. A través de las canciones, podemos negar a comprender mejor la diversidad del mundolatinoamericano.

Infernet <www.ciberamerica, org > (con adaptaciones)
En base a las informaciones del texto de amíba, juzgue los síguientes items.

24 En la cita del Quijote, Sancho se refiere a lo positivo del arte musical en la vida de las personas.

25 El comienzo de la música folclórica latinoamericana está bien documentado.

26 La letra de las músicas de Latinoamérica sirvió, en el pasado, como un medio de comunicación.

27 La música folclórica americana se perdió, en tiempos remotos, sin dejár un legado para la actualidad.

$28 \mathrm{Ni}$ siempre las canciones referidas en el texto podian ser leídas portodos.

29 Según el texto, la canción latinoamericana ganó importancia en la actualidad por su riquezalingüística.

38 El textofocaliza los tipos de música basados en letrá.
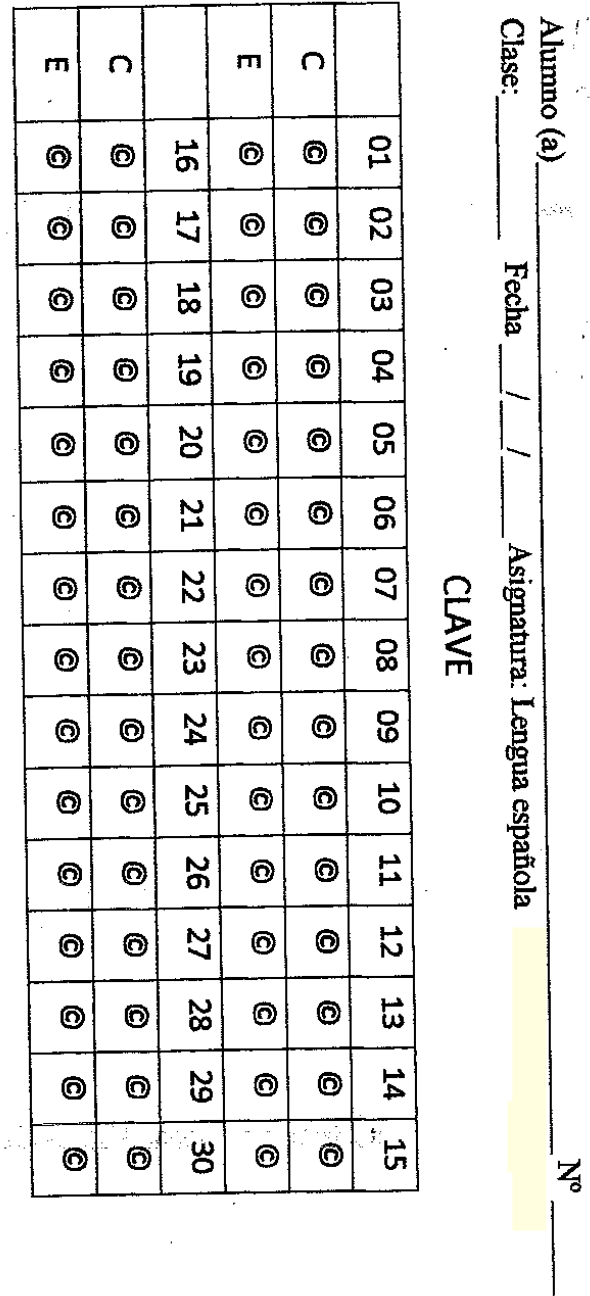


\section{ANEXO O - EXERCÍCIO DE REVISÃO (9a OBSERVAÇÃO - PARANOÁ)}

NOMBRE Y APELLIDOS

CLASE:

FECHA

ASIGNATURA: LENGUA ESPAÑOLA

REPASO

1. Completa la tabla con los verbos en pretérito imperfecto de subjuntivo.

\begin{tabular}{|l|l|l|l|l|l|}
\hline & encontrar & esperar & ayudar & saber & Tener \\
\hline yo & & & & & \\
\hline tu & & & & & \\
\hline él/ella/usted. & & & & & \\
\hline nosotros & & & & & \\
\hline vosotros & & & & & \\
\hline ellos/ellas/ustedes. & & & & & \\
\hline
\end{tabular}

2. Completa la tabla con los verbos en pretérito perfecto de subjuntivo.

\begin{tabular}{|l|l|l|l|}
\hline & encontrar & hacer & perder \\
\hline yo & & & \\
\hline tu & & & \\
\hline él/ella/usted. & & & \\
\hline nósotros & & & \\
\hline vosotros & & & \\
\hline ellos/ellas/ustedes. & & & \\
\hline
\end{tabular}

\begin{tabular}{|l|l|l|l|}
\hline & escribir & huir & ir \\
\hline yo & & & \\
\hline tu & & & \\
\hline él/ella/usted & & & \\
\hline nosotros & & & \\
\hline vosotros & & & \\
\hline ellos/ellas/ustedes. & & & \\
\hline
\end{tabular}

3. Conyuga el pretérito pluscuamperfecto de subjuntivo en la tercera persona de singular.
a. hacer
b. ser
c. escribir 
4. Completa la tabla con los verbos en pretérito perfecto de subjuntivo.

\begin{tabular}{|l|l|l|l|}
\hline & encontrar & hacer & perder \\
\hline yo & & & \\
\hline tu & & & \\
\hline el/ella/usted. & & & \\
\hline nosotros & & & \\
\hline vosotros & & & \\
\hline ellos/cllas/ustedes & & & \\
\hline
\end{tabular}

5. Conyuga en imperativo afirmativo y negativo en la persona que se indica.

\begin{tabular}{|l|l|l|}
\hline & Afirmativo & Negativo \\
\hline Revisar (tú) & & \\
\hline Decir (tú) & & \\
\hline Acostarse(él) & & \\
\hline Hacer(tú) & & \\
\hline Cenar(él) & & \\
\hline Practicar(ella) & & \\
\hline cancelar (tú) & & \\
\hline Mandar (tú) & & \\
\hline Cambiar (él) & & \\
\hline Dormir (él) & & \\
\hline Pensar (él) & & \\
\hline Darse (usted) & & \\
\hline
\end{tabular}

